Al11,00 990190

NAT'L INST OF STANDARDS \& TECH R.I.C.

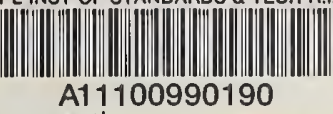

NBS MONOGRAPH 124

INBS

QC100.U556 V124;1972 C.1 NBS-PUB-C 1959

\title{
Reference Tables \\ for Low-Temperature Thermocouples
}

U.S. EPARTMENT

OF COMMERCE National

Bureau of

Standards

$Q C$

100

. 4556

no. 124

1972

c. 2 
The National Bureau of Standards ${ }^{1}$ was established by an act of Congress March 3, 1901. The Bureau's overall goal is to strengthen and advance the Nation's science and technology and facilitate their effective application for public benefit. To this end, the Bureau conducts research and provides: (1) a basis for the Nation's physical measurement system, (2) scientific and technological services for industry and government, (3) a technical basis for equity in trade, and (4) technical services to promote public safety. The Bureau consists of the Institute for Basic Standards, the Institute for Materials Research, the Institute for Applied Technology, the Center for Computer Sciences and Technology, and the Office for Information Programs.

THE INSTITUTE FOR BASIC STANDARDS provides the central basis within the United States of a complete and consistent system of physical measurement; coordinates that system with measurement systems of other nations; and furnishes essential services leading to accurate and uniform physical measurements throughout the Nation's scientific community, industry, and commerce. The Institute consists of a Center for Radiation Research, an Office of Measurement Services and the following divisions:

Applied Mathematics-Electricity-Heat-Mechanics-Optical Physics-Linac Radiation ${ }^{2}$ - Nuclear Radiation ${ }^{2}$ - Applied Radiation ${ }^{2}-$ Quantum Electronics ${ }^{3}$ Electromagnetics ${ }^{3}$ - Time and Frequency ${ }^{3}$ - Laboratory Astrophysics ${ }^{3}$ - Cryogenics ${ }^{3}$.

THE INSTITUTE FOR MATERIALS RESEARCH conducts materials research leading to improved methods of measurement, standards, and data on the properties of well-characterized materials needed by industry, commerce, educational institutions, and Government; provides advisory and research services to other Government agencies; and develops, produces, and distributes standard reference materials. The Institute consists of the Office of Standard Reference Materials and the following divisions:

Analytical Chemistry-Polymers-Metallurgy-Inorganic Materials-Reactor Radiation-Physical Chemistry.

THE INSTITUTE FOR APPLIED TECHNOLOGY provides technical services to promote the use of available technology and to facilitate technological innovation in industry and Government; cooperates with public and private organizations leading to the development of technological standards (including mandatory safety standards), codes and methods of test; and provides technical advice and services to Government agencies upon request. The Institute also monitors NBS engineering standards activities and provides liaison between NBS and national and international engineering standards bodies. The Institute consists of the following divisions and offices:

Engineering Standards Services-Weights and Measures-Invention and Innovation-Product Evaluation Technology-Building Research-Electronic Technology-Technical Analysis-Measurement Engineering-Office of Fire Programs.

THE CENTER FOR COMPUTER SCIENCES AND TECHNOLOGY conducts research and provides technical services designed to aid Government agencies in improving cost effectiveness in the conduct of their programs through the selection, acquisition, and effective utilization of automatic data processing equipment; and serves as the principal focus within the executive branch for the development of Federal standards for automatic data processing equipment, techniques, and computer languages. The Center consists of the following offices and divisions:

Information Processing Standards-Computer Information-Computer Services -Systems Development-Information Processing Technology.

THE OFFICE FOR INFORMATION PROGRAMS promotes optimum dissemination and accessibility of scientific information generated within NBS and other agencies of the Federal Government; promotes the development of the National Standard Reference Data System and a system of information analysis centers dealing with the broader aspects of the National Measurement System; provides appropriate services to ensure that the NBS staff has optimum accesssibility to the scientific information of the world, and directs the public information activities of the Bureau. The Office consists of the following organizational units:

Office of Standard Reference Data-Office of Technical Information and Publications-Library-Office of International Relations.

\footnotetext{
${ }^{1}$ Headquarters and Laboratories at Gaithersburg, Maryland, unless otherwise noted; mailing address Washington, D.C. 20234

2 Part of the Center for Radiation Research.

${ }^{3}$ Located at Boulder, Colorado 80302.
} 


\section{Reference Tables for Low-Temperature Thermocouples}

Larry L. Sparks, Robert L. Powell, and William J. Hall

Institute for Basic Standards National Bureau of Standards Boulder, Colorado 80302 thevajaph vio. 1:24

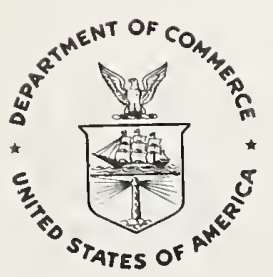

U.S. DEPARTMENT OF COMMERCE, Peter G. Peterson, Secretary NATIONAL BUREAU OF STANDARDS, Lawrence M. Kushner, Acting Director Issued June 1972 
Library of Congress Catalog Number: 74-186212

National Bureau of Standards Monograph 124

Nat. Bur. Stand. (U.S.), Monogr. 124, 61 pages, (June 1972)

CODEN: NBSMA6

For sale by the Superintendent of Documents, U.S. Government Printing Office, Washington, D.C. 20402

(Order by SD Catalog No. C 13.44:124). Price 60 cents.

Stock Number 0303-0952 
1. Introduction

2. Material Specifications

3. Preliminary Selection and Inhomogeneity Tests

4.

A pparatus

Experimental Design and Technique.

Data Analysis

Error Analysis

Standard Tables and Functions

9. References.

Appendix A. Standard Designations for Thermocouples.

\section{List of Figures}

Figure

1. (a) Short-range inhounogeneity probe. (b) Medium-range, long-range, and inter-lot homogeneity probe. (c) Differential thermocouple probe.

2. Schematic of thermocouple calibration cryostat

3. Flange and trough arrangement for using low melting point solder to make cryogenic vacuum seals.

4. Schematic of thermal and electrical placement of thermometers in the calibration system

5. Block diagram of thermocouple calibration instrumentation

6. Four object measurement graph

7. Measurement graph used for calibration of thermocouple materials TP, KP (or EP), KN, TN (or EN), Pt, Ag-0.37 at $\% \mathrm{Au}$, and $\mathrm{Ag}-28$ at\% $\mathrm{Au}$

8. Graph of $\left|\mathrm{A}_{n}\right|$ versus number of coefficients for thermocouple Type $\mathrm{T}$

9. Least squares approximations to typical data before the range shift constants are applied...................

10. Characteristic propagated standard deviation $\left(\sigma_{E}\right)$ in voltage for the thermocouple calibrations .............

11. Illustration of the nonzero thermoelectric voltage at $T=0 \mathrm{~K}$ which results when experimental data are extrapolated from $5 \mathrm{~K}$ to $0 \mathrm{~K}$

12. Thermoelectric voltage for primary thermocouple types $\mathrm{E}, \mathrm{K}$, and $\mathrm{T}$

13. Seebeck coefficient for primary thermocouple types $\mathrm{E}, \mathrm{K}$, and $\mathrm{T}$

14. Derivative of the Seebeck coefficient for primary thermocouple types $\mathrm{E}, \mathrm{K}$, and $\mathrm{T}$

15. Thermoelectric voltage for thermocouple materials versus $\mathrm{Pt}$

16. Seebeck coefficient for thermocouple materials versus $\mathrm{Pt}_{\mathrm{t}}$

17. Thermoelectric voltage for thermocouple materials versus $\mathrm{Ag} \cdot 28$ at\% $\mathrm{Au}$

18. Seebeck coefficient for thermocouple materials versus Ag. 28 at\% Au

\section{List of Tables}

Table

1. Total inventory of tested materials for thermocouple types $\mathrm{E}, \mathrm{K}$, and $\mathrm{T}$ and the reference materials Ag-28 at\% $\mathrm{Au}$ and $\mathrm{Pt}$

2. Range of chemical compositions for the tested thermocouple wires

3. Physical characteristics of some typical thermocouple test wires

4. Thermocouple wire inhomogeneity data

5. Comparison of differential thermocouple dip test data with previously published data and with data from NBS internal reports.

6. Kink and strain effects on thermocouple wires

7. A verage values of the standard deviations for the main thermocouple combinations -

8. Average values of the standard deviation of the secondary thermocouple combinations, average values for the standard deviation of the adjustment constant, and the overall standard deviation resulting from the combined effect of these uncertainties.

9. Estimates of systematic errors in temperature measurements

10. Estimated systematic errors in thermocouple voltage readings

11. Total uncertainties in thermocouple calibrations

12. Type E-thermoelectric voltage, $E(T)$, Seebeck coefficient, $S(T)$, and derivative of the Seebeck coefficient, $d S(T)$ 


\section{List of Tables-Continued}

Table

13. Type $\mathrm{K}$-thermoelectric voltage, $E(T)$, Seebeck coefficient, $S(T)$, and derivative of the Seebeck coefficient, $d S(T)$

14. Type T-thermoelectric voltage, $E(T)$, Seebeck coefficient, $S(T)$, and derivative of the Seebeck coefficient, $d S(T)$

15. Type $\mathrm{E}$-reduced precision tables, $E(T)$

16. Type $\mathrm{K}$-reduced precision tables, $E(T)$

17. Type T-reduced precision tables, $E(T)$

18. Type $\mathbf{E}$-reduced precision tables, $T(E)$

19. Type $\mathrm{K}$-reduced precision tables, $T(E)$

20. Type T-reduced precision tables, $T(E)$.

21. Type KP (or EP) versus Pt-thermoelectric voltage, $E(T)$, Seebeck coefficient, $S(T)$, and derivative of the Seebeck coefficient, $d S(T)$

22. Type Pt versus TN (or EN)-thermoelectric voltage, $E(T)$, Seebeck coefficient, $S(T)$, and derivative of the Seebeck coefficient, $d S(T)$

23. Type $\mathrm{Pt}$ versus $\mathrm{KN}$-thermoelectric voltage, $E(T)$, Seebeck coefficient, $S(T)$, and derivative of the Seebeck coefficient, $d S(T)$

24. Type Pt versus TP-thermoelectric voltage, $E(T)$, Seebeck coefficient, $S(T)$, and derivative of the Seebeck coefficient, $d S(T)$

25. Type KP (or EP) versus Ag-28 at\% Au-thermoelectric voltage, $E(T)$, Seebeck coefficient, $S(T)$, and derivative of the Seebeck coefficient, $d \bar{S}(T)$.

26. Type Ag-28 at\% Au versus TN (or EN) - thermoelectric voltage, $E(T)$, Seebeck coefficient, $S(T)$, and derivative of the Seebeck coefficient, $d S(T)$.

27. Type Ag-28 at\% Au versus KN-thermoelectric voltage, $E(T)$, Seebeck coefficient, $S(T)$, and derivative of the Seebeck coefficient, $d S(T)$

28. Type TP versus Ag-28 at\% Au-thermoelectric voltage, $E(T)$, Seebeck coefficient, $S(T)$, and derivative of the Seebeck coefficient, $\overline{d S}(T)$

29. Type $\mathrm{Pt}$ versus Ag-28 at\% Au-thermoelectric voltage, $E(T)$, Seebeck coefficient, $S(T)$, and derivative of the Seebeck coefficient, $\overline{d S}(T)$

30. Orthonormal polynomials, $F_{n}(T)$

31. Orthonormal polynomial coefficients for thermocouple types T, E, K, Pt versus TP, KP (or EP) versus Pt, and Pt versus $\mathrm{KN} ; E=f(T)$

32. Orthonormal polynomial coefficients for thermocouple types Pt versus TN (or EN), KP (or EP) versus Ag-28 at\% Au, Ag-28 at\% Au versus KN, TP versus Ag-28 at\% Au, Ag-28 at\% Au versus TN (or EN), and Pt versus Ag-28 at $\overline{\mathrm{Au}} ; E=f(T)$

33. Standard deviations $(\mu V)$ of reduced order fits for thermocouple types T, E, K, Pt versus TP, KP (or EP) versus Pt, and Pt versus KN; $E=f(T)$

34. Standard deviations $(\mu \mathrm{V})$ of reduced order fits for thermocouple types Pt versus TN (or EN), KP (or EP) versus $\mathrm{Ag}-28$ at\% Au, Ag-28 at\% Au versus KN, TP versus Ag-28 at\% Au, Ag-28 at\% Au versus TN (or EN), and Pt versus $\overline{\mathrm{Ag}}-28$ at $\% \mathrm{Au} ; \bar{E}=f(T)$.

35. Number of digits necessary in computations to reduce round-off errors below certain limits for thermocouple types $\mathrm{E}, \mathrm{K}$, and $\mathrm{T}$.

36. Power series coefficients for thermocouple types T, E, K, Pt versus TP, KP (or EP) versus Pt, and Pt versus $\mathrm{KN} ; E=f(T)$

37. Power series coefficients for thermocouple types Pt versus TN, KP (or EP) versus Ag-28 at\% Au, Ag-28 at\% Au

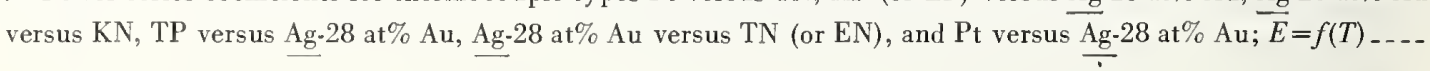




\title{
Reference Tables for Low-Temperature Thermocouples*
}

\author{
Larry L. Sparks, Robert L. Powell, and William J. Hall \\ Institute for Basic Standards, National Bureau of Standards, Boulder, Colorado 80302
}

\begin{abstract}
The experimental prograin to establish low-temperature reference tables for the commonly used thermocouples has been completed. Details of the experimental system, instrumentation, data analysis, error analysis, and materials tested are given in order to allow the user to better evaluate and apply the results. The results presented here include:
\end{abstract}

(1) Reference tables for thermocouple types $\mathrm{E}, \mathrm{K}$, and $\mathrm{T}$, both as $E=f(T)$ and $T=f(E)$. The shorter $f(E)$ tables have a $0{ }^{\circ} \mathrm{C}(273.15 \mathrm{~K})$ reference temperature while all other tables have a $0 \mathrm{~K}$ reference temperature.

(2) Reference tables for $\mathrm{Pt}$ and $\mathrm{Ag}-28$ at $\% \mathrm{Au}$ vs the materials used in thermocouple types $\mathrm{E}, \mathrm{K}$, and T. These data are presented as $E=f(T)$ only.

(3) Orthogonal polynomials and the associated coefficients necessary to generate the data with reduced order approximations.

(4) Power series coefficients for full precision reproduction of the reference data.

The data presented in the $E=f(T)$ tables cover the temperature range from 0 to $280 \mathrm{~K}$. The $T=f(E)$ tables cover the temperature ranges from $273.15 \mathrm{~K}$ down to the lowest temperatures allowed by table resolution.

Key words: Cryogenics; homogeneity tests; liquid helium; liquid hydrogen; liquid nitrogen; thermocouples.

\section{Introduction}

The rapid expansion of cryogenic technology in the last 20 years has created a need for standardized thermocouple calibrations in the cryogenic temperature range. Therefore, an extensive experimental program was initiated at this laboratory to provide the necessary reference data. The overall thermo. electric thermometry program had several objectives: (1) to establish standard thermoelectric reference tables between 4 and $280 \mathrm{~K}$ for thermocouple types $\mathrm{E}, \mathrm{K}$, and $\mathrm{T}^{1}$; (2) to select and test a material for use as a thermoelectric standard below $50 \mathrm{~K}$; (3) to compare materials of the same nominal composition to determine the degree of thermoelectric interchangeability; and (4) to test new thermocouple combinations for possible advantages in specific situations. Results for the first three goals are discussed in this paper; further research must be done on the newer combinations before they can be considered standard materials.

In order to establish thermoelectric values which are representative of thermocouple materials currently being used, we obtained wire from all major thermocouple wire producers in the United States. Most manufacturers submitted two or three spools

- This work was carried out at the National Bureau of Standards under the sponsorship of the National Aeronautics and Space Administration, Sprace Nuclear Propulsion Office (SNPO-C), Order Number R-45 and W13,300.

1 The letter designations for thermocouples are explained in Appendix A. Any material manufactured in compliance with an established standard is equally suitable. of wire which were representative of each material requested. Exhaustive preliminary testing was done to determine which of the wires were to be used in the detailed calibration. The final reference values in this report are based on the characteristics of individual wires; they do not represent averages of all the similar wires from the many different companies. Members of the E-20 committee of the American Society for Testing and Materials (ASTM) and the thermocouple wire producers were extremely cooperative throughout the program; the wide selection of representative wires and the chemical analysis of the melts would have been difficult to obtain without their cooperation.

Traditionally, platinum has been used as the thermoelectric reference standard for production control. For temperatures above approximately $50 \mathrm{~K}$, it retains the thermoelectric properties of a good reference material. Below $50 \mathrm{~K}$, however, the thermopower of platinum becomes very dependent upon trace chem. ical impurities - notably iron. Since trace impurities of iron are difficult to remove from platinum, a thermoelectric reference material which is not as sensitive to trace impurities is needed to replace platinum below $50 \mathrm{~K}$. An alloy of gold in silver has been tested in this laboratory, and it appears to meet the requirements for a low temperature thermoelectric reference material. 
The design of our experimental system and of our data acquisition procedure produced a large amount of information on secondary combinations, such as intercomparisons of similar wires from different producers. Knowledge of the comparative thermoelectric behavior of similar wires is of critical importance when adjusting standard reference data to represent a particular thermocouple.
The purpose of this monograph is to present recently acquired data for low temperature thermocouples. Details of the cryostat, measurement scheme, error analysis, analytical representation of the experimental data, etc., are included to allow the individual user to judge the creditability of the data and to further understand the extent and limitations of the experiments.

\section{Material Specifications}

Materials to be used in the thermocouple calibration program were requested from all major United States producers. Each company was asked to furnish representative samples of the thermocouple materials that they distribute. Multiple spools of each material were requested whenever different melts were available. A list of the wires received for initial testing is given in table 1. The number of participating manufacturers and the total number of spools of each material are also indicated in this table. The complete inventory of wires was tested to determine the degree of thermoelectric homogeneity and interchangability. Results of these preliminary tests are of considerable practical interest and are discussed in detail in the following section. The wires to be included in the detailed calibration from 4 to $280 \mathrm{~K}$ were selected after considering the resulis of the preliminary tests. Whenever possible, one test wire of each type from each company was included - the one most homogeneous and closest to the accepted high-temperature standard values. Only one wire of each type, however, was considered to be the primary wire. The primary wire was used in all appropriate thermoelectric combinations, while the secondary wires were only compared thermoelectrically to the primary wire of the same nominal composition.
TABLE 1. Total inventory of tested materials for thermocouple types $E, K$, and $T$ and the reference materials Ag-28 at\% Au and $\mathrm{Pt}$

\begin{tabular}{l|c|c}
\hline \hline $\begin{array}{c}\text { ASTM designation or } \\
\text { nominal composition }\end{array}$ & $\begin{array}{c}\text { Number of } \\
\text { manufacturers } \\
\text { represented }\end{array}$ & $\begin{array}{c}\text { Number } \\
\text { of } \\
\text { spools }\end{array}$ \\
\hline EP or KP & 3 & 9 \\
EN or TN & 4 & 10 \\
TP & 3 & 9 \\
\hline Ag-28 at\% Au & 2 & 4 \\
\hline
\end{tabular}

The chemical compositions and physical conditions of the calibrated wires are given in tables 2 and 3 , respectively. The compositions shown in table 2 are the extremes found in the various spools tested. These data were furnished by the cooperating manufacturers. No attempt will be made here to predict the specific thermoelectric effect of each of the components or impurities in the wires. A method of making such a prediction, in principle at least, is

TABLE 2. Range of chemical compositions for the tested thermocouple wires

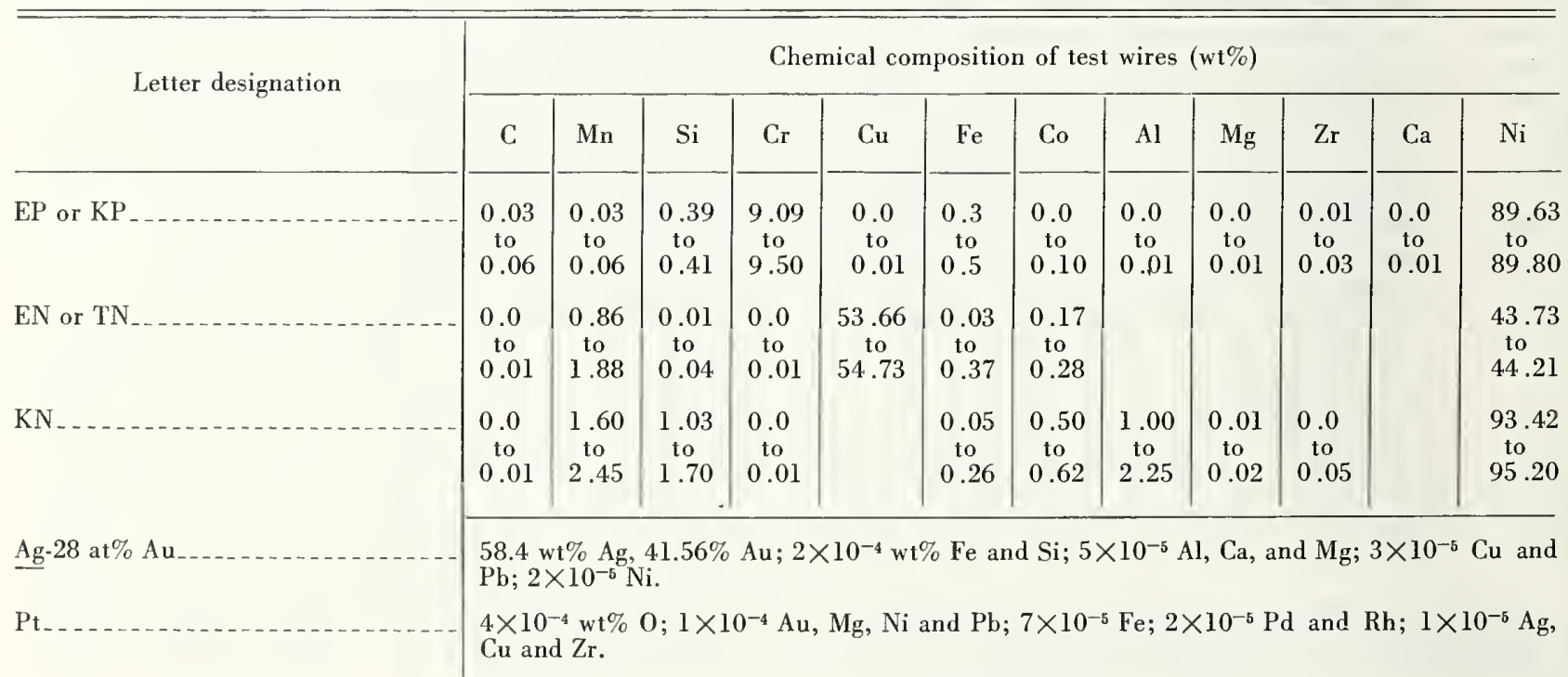


TABLE 3. Physical characteristics of some typical thermocouple test wires

\begin{tabular}{|c|c|c|c|c|c|c|c|}
\hline \multirow{2}{*}{ Thermocouple } & \multicolumn{2}{|c|}{ Wire size } & \multirow{2}{*}{$\begin{array}{l}\text { Insulation } \\
\text { coating* }^{*}\end{array}$} & \multirow{2}{*}{$\begin{array}{l}\text { IJeat } \\
\text { treatment }\end{array}$} & \multirow{2}{*}{$\begin{array}{l}\text { Average } \\
\text { grain } \\
\text { intercept } \\
\text { diameter }\end{array}$} & \multirow{2}{*}{$\begin{array}{l}\text { Maximum } \\
\text { grain } \\
\text { diameter }\end{array}$} & \multirow{2}{*}{ Grain orientation } \\
\hline & $A W G$ & $\begin{array}{l}\text { Diameter } \\
(\mathrm{mm})\end{array}$ & & & & & \\
\hline $\mathrm{EP}$ or $\mathrm{KP} \ldots$ & $\begin{array}{l}32 \\
32 \\
32\end{array}$ & $\begin{array}{r}0.20 \\
.20 \\
.20\end{array}$ & $\begin{array}{l}\text { glass fiber } \\
\text { PVF } \\
\text { PVF }\end{array}$ & $\begin{array}{l}\text { as received } \\
\text { as received } \\
\text { as received }\end{array}$ & $\begin{array}{l}7.1 \mu \mathrm{m} \\
6.4 \\
5.0\end{array}$ & $\begin{array}{l}14 \mu \mathrm{m} \\
13^{12} \\
12\end{array}$ & $\begin{array}{l}\text { no preferred direction } \\
\text { slight axial preference } \\
\text { slight axial preference }\end{array}$ \\
\hline $\mathrm{EN}$ or $\mathrm{TN}_{-}$ & $\begin{array}{l}32 \\
32 \\
30 \\
30\end{array}$ & $\begin{array}{l}.20 \\
.20 \\
.25 \\
.25\end{array}$ & $\begin{array}{l}\text { glass fiber } \\
\text { PVF } \\
\text { PE } \\
\text { PTFE }\end{array}$ & $\begin{array}{l}\text { as received } \\
\text { as received } \\
\text { as received } \\
\text { as received }\end{array}$ & $\begin{array}{l}6.3 \\
6.9 \\
5.6 \\
7.4\end{array}$ & $\begin{array}{l}10 \\
12 \\
14 \\
13\end{array}$ & $\begin{array}{l}\text { slight axial preference } \\
\text { no preferred direction } \\
\text { slight axial preference } \\
\text { slight axial preference }\end{array}$ \\
\hline $\mathrm{KN}_{---}$ & $\begin{array}{l}32 \\
32 \\
32\end{array}$ & $\begin{array}{l}.20 \\
.20 \\
.20\end{array}$ & $\begin{array}{l}\text { PVF } \\
\text { PVF } \\
\text { glass fiber }\end{array}$ & $\begin{array}{l}\text { as received } \\
\text { as received } \\
\text { as received }\end{array}$ & $\begin{array}{l}8.2 \\
5.7 \\
6.2\end{array}$ & $\begin{array}{r}16 \\
9 \\
15\end{array}$ & $\begin{array}{l}\text { slight axial preference } \\
\text { no preferred direction } \\
\text { slight axial preference }\end{array}$ \\
\hline TP $\ldots$ & $\begin{array}{l}32 \\
30\end{array}$ & $\begin{array}{l}.20 \\
.25\end{array}$ & $\begin{array}{l}\text { PTFE } \\
\text { PE }\end{array}$ & $\begin{array}{l}\text { as received } \\
\text { as received }\end{array}$ & $\begin{array}{l}4.8 \\
6.0\end{array}$ & $\begin{array}{l}14 \\
15\end{array}$ & $\begin{array}{l}\text { slight axial preference } \\
\text { slight axial preference }\end{array}$ \\
\hline Ag.28 at $\% \mathrm{Au}_{-}$ & 32 & .20 & $\mathrm{PI}(\mathrm{Lab})$ & $1 \mathrm{~h} / \mathrm{air} / 400^{\circ} \mathrm{C}$ & & & \\
\hline $\mathrm{Pt}_{-\ldots}$ & 32 & .20 & PTFE(Lab) & $1 \mathrm{~h} / \mathrm{air} / 400^{\circ} \mathrm{C}$ & & & \\
\hline
\end{tabular}

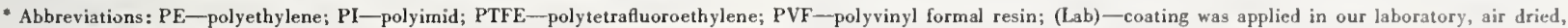
and baked under infrared lamps.

given by MacDonald [1]. ${ }^{2}$ The grain size is significant because it is indicative of the heat treatment history of the wires. As shown in table 3, all of the wires except Pt and Ag-28 at\% Au were tested in the "asreceived" condition.
The platinum and silver-gold alloys are both available as Standard Reference Materials for thermometry from the Office of Standard Reference Materials, National Bureau of Standards, Washington, D.C. 20234 .

\section{Preliminary Selection and Inhomogeneity Tests}

An exhaustive series of preliminary tests were performed on our complete inventory of wires for thermocouple types $\mathrm{E}, \mathrm{K}$, and $\mathrm{T}$. These tests were necessary in order to determine the homogeneity characteristics of each type of wire and to determine the most representative wires from each company. The dip test program performed on these materials was designed to provide information on short range, medium range, and long range inhomogeneities and to compare the present materials to existing or proposed standards.

No thermal voltage is developed when a loop of homogeneous wire is subjected to a temperature gradient. Similarly, no voltage is generated when two identical wires are joined and the pair of wires is placed in a temperature gradient. The problem in practical thermometry is, however, that the ideal characteristics "homogeneous" and "identical" are not sufficiently well approximated for real thermocouple materials. Actually, a loop of wire placed in a large temperature gradient will usually produce a resultant voltage, sometimes as large as 10 microvolts $(\mu \mathrm{V})$ for poor materials. If wire from one spool is connected to wire from a different spool of the same nominal composition, their junction is placed in a

2 Figures in brackets indicate the literature references at the end of this paper. cryogenic fluid, and the free ends are held at room temperature, then a significant voltage may result; we have observed readings as large as hundreds of microvolts for poorly controlled alloys. These variable spurious voltages caused by inhomogeneities, physical imperfections, and chemical impurities are usually the main source of imprecision and inaccuracy in thermocouple systems.

For descriptive convenience, we have divided inhomogeneities into four categories based on their distance of separation:

(1) Short-range inhomogeneities occur in a single wire and are separated by less than five meters, of ten being within a few centimeters of each other.

(2) Medium-range inhomogeneities occur in wires that are from a single spool but are more than five meters apart.

(3) Long-range inhomogeneities are found in wires that are from the same general stock but are from different spools.

(4) Inter-lot variations in chemical composition, thermal treatment, and handling occur in materials produced by different manufacturers, or even in wire produced by the same manufacturer at different times.

The latter categories of inhomogeneities lead to much larger spurious roltages in cryogenic systems. 
Well-prepared thermocouple wire can have shortrange inhomogeneity effects as low as $0.1 \mu \mathrm{V}$; poorly controlled alloys often have inter-lot variations as large as $100 \mu \mathrm{V}$.

Two kinds of probes, shown in figure 1, were used to investigate the various effects of the four categories of inhomogeneities. The first probe configuration, shown in figure $1(a)$, consisted of a single wire about 4 or 5 meters $(\mathrm{m})$ long, part of it attached to a plastic tube. It did not need to have a large number of coils, even straight lengths of wire would have been satisfactory. This probe was used to test for short-range inhomogeneities. The second probe configuration, shown in figure $1(\mathrm{~b})$, consisted of two wires, each 2 or $3 \mathrm{~m}$ long, that were coiled on a plastic tube and joined at the bottom. This probe was used to test for the last three categories of inhomogeneities. The essential difference between the two kinds of probes (besides the junction) was in their manner of thermal tempering; the second kind had tightly wound coils of wire near the junction in order to prevent a thermal gradient across the junction, which often contained dissimilar materials.

For both kinds of probes, the loose ends of the wires were connected to a potentiometer or highresistance voltmeter; the probes were then dipped into dewars containing cryogenic fluids, usually liquid helium or nitrogen. The first type of probe was dipped in two different manners, one way for static tests, another way for dynamic tests.

For static short-range inhomogeneity tests, the probes were immersed to a given depth in the cryogenic

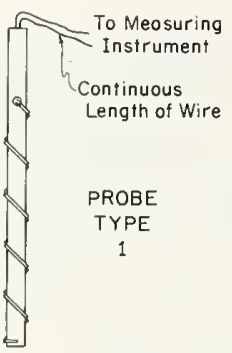

(a)

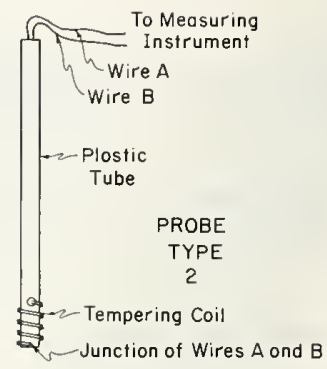

(b)

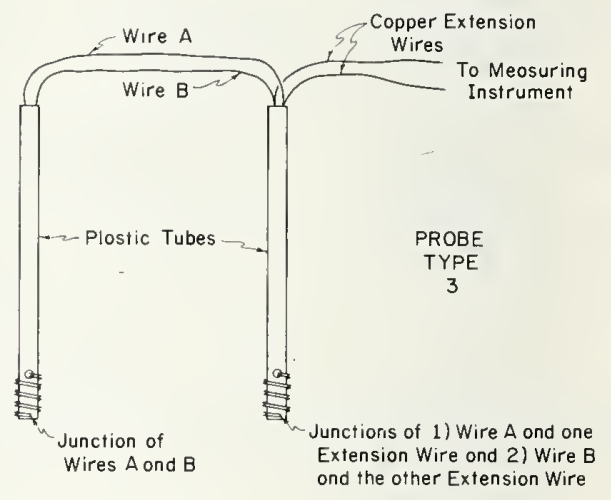

(c)

Figure 1. (a) Short-range inhomogeneity probe. (b) Mediumrange, long-range, and inter-lot homogeneity probe. (c) Differential thermocouple probe.

TABLE 4. Thermocouple wire inhomogeneity data*

\begin{tabular}{|c|c|c|c|c|c|c|c|c|}
\hline \multirow{3}{*}{ Material } & \multirow{3}{*}{ Lot code } & \multicolumn{3}{|c|}{ Short length ${ }^{1}$} & \multirow{2}{*}{\multicolumn{2}{|c|}{$\frac{\text { Medium length }^{2}}{\text { Equilibrium }}$}} & \multirow{2}{*}{\multicolumn{2}{|c|}{$\frac{\text { Different spools }^{3}}{\text { Equilibrium }}$}} \\
\hline & & \multicolumn{2}{|c|}{ Equilibrium } & \multirow{2}{*}{$\begin{array}{l}\text { Dynamic } \\
\text { Liq } \mathrm{N}_{2}\end{array}$} & & & & \\
\hline & & Liq $\mathrm{N}_{2}$ & $\mathrm{Liq} \mathrm{He}$ & & Liq $\mathrm{N}_{2}$ & Liq $\mathrm{He}$ & Liq $\mathrm{N}_{2}$ & Liq He \\
\hline $\mathrm{EP}, \mathrm{KP}$ & $\begin{array}{l}\mathrm{A} \\
\mathrm{B} \\
\mathrm{C}\end{array}$ & $\begin{array}{l}0.5 \mu \mathrm{V} \\
1.0 \\
2.6\end{array}$ & $\begin{array}{l}0.9 \mu \mathrm{V} \\
1.2 \\
2.6\end{array}$ & $\begin{array}{l}5.5 \mu \mathrm{V} \\
6.9 \\
8.2\end{array}$ & $\begin{array}{l}2.2 \mu \mathrm{V} \\
1.0 \\
4.5\end{array}$ & $\begin{array}{l}2.2 \mu \mathrm{V} \\
1.0 \\
4.5\end{array}$ & $\begin{array}{c}28.0 \mu \mathrm{V} \\
38.0 \\
4.4\end{array}$ & $\begin{array}{c}33.4 \mu \mathrm{V} \\
39.1 \\
6.1\end{array}$ \\
\hline $\mathrm{EN}, \mathrm{TN}$ & $\begin{array}{l}\mathrm{D} \\
\mathrm{E} \\
\mathrm{F} \\
\mathrm{G}\end{array}$ & $\begin{array}{l}0.9 \\
3.0 \\
2.8 \\
1.6\end{array}$ & $\begin{array}{l}1.2 \\
3.0 \\
2.8 \\
2.1\end{array}$ & $\begin{array}{l}1.3 \\
5.1 \\
8.3 \\
6.8\end{array}$ & $\begin{array}{r}1.6 \\
2.4 \\
10.8 \\
5.8\end{array}$ & $\begin{array}{r}1.7 \\
2.5 \\
12.5 \\
5.8\end{array}$ & $\begin{array}{r}6.6 \\
26.0 \\
36.0\end{array}$ & $\begin{array}{r}6.6 \\
27.7 \\
44.4\end{array}$ \\
\hline KN & $\begin{array}{l}\mathrm{H} \\
\mathrm{I} \\
\mathrm{J}\end{array}$ & $\begin{array}{l}0.7 \\
1.9 \\
2.0\end{array}$ & $\begin{array}{l}0.7 \\
2.4 \\
2.0\end{array}$ & $\begin{array}{l}13.7 \\
14.1 \\
21.4\end{array}$ & $\begin{array}{l}3.8 \\
2.2 \\
2.6\end{array}$ & $\begin{array}{l}4.9 \\
2.2 \\
2.6\end{array}$ & $\begin{array}{r}42.0 \\
1.7 \\
4.6\end{array}$ & $\begin{array}{r}45.4 \\
2.8 \\
4.6\end{array}$ \\
\hline $\mathrm{TP}$ & $\begin{array}{l}\mathrm{K} \\
\mathrm{L}\end{array}$ & $\begin{array}{l}0.4 \\
0.2\end{array}$ & $\begin{array}{l}0.4 \\
1.4\end{array}$ & $\begin{array}{l}1.0 \\
1.1\end{array}$ & $\begin{array}{l}0.4 \\
1.9\end{array}$ & $\begin{array}{l}0.7 \\
7.6\end{array}$ & $\begin{array}{l}0.5 \\
4.1\end{array}$ & $\begin{array}{r}0.5 \\
37.9\end{array}$ \\
\hline $\mathrm{Pt}$ & M & 0.3 & 2.4 & 3.4 & & & & \\
\hline $\mathrm{Ag}-28$ at $\% \mathrm{Au}$ & $N$ & 0.3 & 0.3 & 1.8 & & 0.3 & & 0.3 \\
\hline
\end{tabular}

* Reported data are maximums.

1 Continuous length of wire-approximately 5 meters.

2 Compares front and back ends of a single roll- -30 to 150 meters.

3 Widely separated lengths of wires from different spools. 


\begin{tabular}{|c|c|c|c|}
\hline \multirow{3}{*}{ Thermocouple type } & \multicolumn{3}{|c|}{ Percentage deviations ${ }^{1}$} \\
\hline & \multicolumn{2}{|c|}{ Ice temperature to liquid $\mathrm{N}_{2}$} & \multirow{2}{*}{$\frac{\text { Liquid } \mathrm{N}_{2} \text { to liquid tle }}{\text { Interim tables }}$} \\
\hline & NBS Circ. $561^{2}$ & Interim tables ${ }^{3}$ & \\
\hline $\mathbf{E}_{--}$ & +0.38 to +1.29 & -0.19 to +0.72 & $-1.6810+1.07$ \\
\hline K $\ldots \ldots$ & -0.45 to +0.23 & +2.14 to +2.27 & -0.54 to +2.3 \\
\hline$T_{\ldots} \ldots \ldots$ & -0.11 to +0.31 & +0.89 to +1.31 & -2.07 เo -1.70 \\
\hline
\end{tabular}

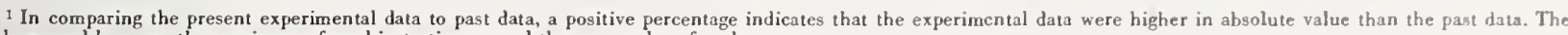
values used here are the maximums found in testing several thermocouples of each type.

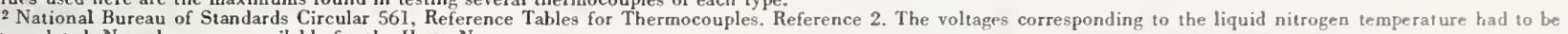
extrapolated. No values were available for the He to $\mathrm{N}_{2}$ range.

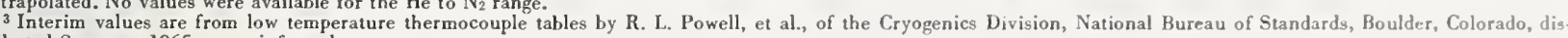
tributed Summer, 1965, as an informal report.

fluid and the temperature gradient was allowed to come to equilibrium before readings were taken. In order to obtain more representative values, readings were usually taken at three different levels for each test.

For dynamic short-range inhomogeneity tests, the probes were lowered into the fluid at a constant speed. Erratic output voltages were usually observed in these tests because large temperature gradients were developed over different, relatively short lengths of wire as the depth of immersion was changed. The magnitude of the output depended on the type of thermocouple wire, the specific specimen, and, to some extent, the rate of immersion. Since comparable results were desired, a constant immersion rate, 0.5 meter per minute, was used for our tests.

The dynamic, short-range tests were sensitive because large temperature gradients were established over short sections of wire which could contain significant chemical and physical defects. However, when the thermal gradients were allowed to diffuse, as in the static short-range tests, the random thermoelectric voltages tended to cancel one another and the extreme readings became smaller. The static tests were therefore less sensitive indicators of inhomogeneities.

Short-range inhomogeneity tests were useful for selecting homogeneous wire that had a minimum amount of spurious voltages. Results from the tests also gave a good preliminary estimate for the imprecision that could be expected for temperature measurements in the actual cryogenic system. Results from dynamic tests were most appropriate for systems with rapidly fluctuating temperatures or liquid levels; results from static tests were most appropriate for stable cryogenic systems like our laboratory cryostat. Wire that exhibited unusually high spurious thermal voltages (typical values are given later in this section) could be detected and rejected before costly installation in the specialized cryostat.

For tests on medium- or long-range inhomogenei- ties, or inter-lot variations, the probe configuration shown in figure 1 (b) was used. The only differences were in the methods for selection of wires that were assembled in the test rig. The selection criteria were simply those implied in the basic definitions of the three categories of inhomogeneities. The manner of joining the wires was not critical as long as good electrical contact was obtained and the materials were not strained or thermally treated more than a few centimeters away from the junction. The assembled probes were dipped into a cryogenic fluid in the same manner as in static short-range inhomogeneity tests.

Medium- and long-range inhomogeneity tests were useful for determining the variations that occurred in selected lots of thermocouple wire. The deviations in voltage usually became progressively larger as the original positions of the wires became more widely separated. If the material varied beyond acceptable limits, then it was not used in the final calibrations.

The third kind of probe, shown in figure l(c), was a simple differential thermocouple that was used to determine the thermoelectric voltages at fixed points for the standardized wire types in our inventory. One of the criteria used in selecting wires for the detailed calibrations was that the wire's roltage should be reasonably close to the values given in the former standard tables contained in NBS Circular 561 [2].

Table 4 lists typical results for the four kinds of standardized thermocouple wires tested in this program. The values were obtained using Probe Types 1 and 2 at liquid nitrogen and helium temperatures. Table 5 gives the range of deviations that were obtained for Types $\mathrm{E}, \mathrm{K}$, and $\mathrm{T}$ thermocouples tested at liquid nitrogen and helium temperatures using Type 3 Probes.

A number of samples of each material were given special tests to determine the effect of accidental kinking or straining. The test samples for this case were obtained by deliberately inducing short radius bends (kinks) in the test wire for the "kink" tests and by elongating one leg of the test sample by 2 
TABLE 6. Kink and strain effects on thermocouple wire

\begin{tabular}{|c|c|c|c|c|c|c|c|c|c|c|}
\hline \multirow{3}{*}{ Material } & \multirow{3}{*}{ Lot code } & \multicolumn{3}{|c|}{ Kink $^{2}$} & \multicolumn{3}{|c|}{ Strain $^{2}$} & \multicolumn{3}{|c|}{ Undamaged $^{3}$} \\
\hline & & \multicolumn{2}{|c|}{ Equilibrium } & \multirow{2}{*}{$\frac{\text { Dynamic }}{\text { Liq } \mathrm{N}_{2}}$} & \multicolumn{2}{|c|}{ Equilibrium } & \multirow{2}{*}{$\frac{\text { Dynamic }}{\text { Liq } \mathrm{N}_{2}}$} & \multicolumn{2}{|c|}{ Equilibrium } & \multirow{2}{*}{$\frac{\text { Dynamic }}{\text { Liq } \mathrm{N}_{2}}$} \\
\hline & & $\mathrm{Liq} \mathrm{He}$ & Liq $\mathrm{N}_{2}$ & & Liq $\mathrm{He}$ & Liq $\mathrm{N}_{2}$ & & Liq $\mathrm{He}$ & Liq $\mathrm{N}_{2}$ & \\
\hline $\mathrm{EP}, \mathrm{KP}$ & $\begin{array}{l}\mathrm{A} \\
\mathrm{B} \\
\mathrm{C}\end{array}$ & $\begin{array}{l}6.0 \mu \mathrm{V} \\
1.6 \\
2.2\end{array}$ & $\begin{array}{l}5.0 \mu \mathrm{V} \\
1.6 \\
2.2\end{array}$ & $\begin{array}{l}10.5 \mu \mathrm{V} \\
5.8 \\
17.1\end{array}$ & $\begin{array}{l}8.5 \mu \mathrm{V} \\
5.7\end{array}$ & $\begin{array}{l}7.2 \mu \mathrm{V} \\
4.4\end{array}$ & $\begin{array}{l}9.0 \mu \mathrm{V} \\
4.3\end{array}$ & $\begin{array}{l}0.4 \mu \mathrm{V} \\
1.2 \\
0.1\end{array}$ & $\begin{array}{l}0.4 \mu \mathrm{V} \\
1.0 \\
0.1\end{array}$ & $\begin{array}{l}4.2 \mu \mathrm{V} \\
6.9 \\
5.5\end{array}$ \\
\hline $\mathrm{EN}, \mathrm{TN}$ & $\begin{array}{l}\mathrm{D} \\
\mathrm{E} \\
\mathrm{F}\end{array}$ & $\begin{array}{l}1.3 \\
1.4 \\
4.8\end{array}$ & $\begin{array}{l}1.3 \\
1.4 \\
3.8\end{array}$ & $\begin{array}{l}5.4 \\
5.9 \\
8.0\end{array}$ & 4.7 & 4.7 & 6.9 & $\begin{array}{l}3.0 \\
0.4 \\
2.1\end{array}$ & $\begin{array}{l}3.0 \\
0.3 \\
2.1\end{array}$ & $\begin{array}{l}4.0 \\
0.8 \\
6.8\end{array}$ \\
\hline $\mathrm{KN}$ & $\begin{array}{l}\mathrm{G} \\
\mathrm{H} \\
\mathrm{I}\end{array}$ & $\begin{array}{l}1.2 \\
1.0 \\
3.3\end{array}$ & $\begin{array}{l}0.8 \\
1.0 \\
3.3\end{array}$ & $\begin{array}{l}7.4 \\
6.6 \\
9.7\end{array}$ & $\begin{array}{l}4.0 \\
1.3\end{array}$ & $\begin{array}{l}2.8 \\
1.3\end{array}$ & $\begin{array}{l}7.3 \\
9.8\end{array}$ & $\begin{array}{l}1.0 \\
0.7 \\
1.4\end{array}$ & $\begin{array}{l}1.0 \\
0.7 \\
1.4\end{array}$ & $\begin{array}{r}7.6 \\
10.0 \\
12.3\end{array}$ \\
\hline
\end{tabular}

1 Kinks were formed by forming a loop in the wire and applying tension; 6 kinks were made on each wire.

2 The wires were strained by a $2 \%$ elongation.

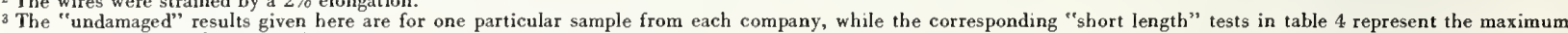
values from several spools from each company.

percent in the "strain" test. Results of these "kink" and "strain" tests are given in table 6, along with similar tests performed before the wire was damaged. These tests were not performed on each wire sample from each manufacturer; however, the general effect of abusing thermocouple wire is evident. The samples used in these tests should represent the outer limit of damage to wires in ordinary assemblies from accidental cold working.

Experimental methods described above allowed us to select materials that were most homogeneous and therefore had the smallest amount of spurious voltages. The tests also provided data necessary for making realistic error analyses.

\section{Apparatus}

A schematic of the cryostat used to determine the thermal voltage for temperatures between 4 and $280 \mathrm{~K}$ is shown in figure 2. The principal parts are labelled UPPER CHAMBER and LOWER CHAMBER. The two chambers are connected by a thermal stand-off tube which serves as a wire duct and allows gas conduction from the lower to the upper chambers. During operation, the lower chamber contains the cryogen. The cryogenic liquid serves as the reference junction for the thermocouples, provides a source of refrigeration for the upper chamber, and serves as a heat sink for all wires that are in the upper chamber. The upper chamber contains a heavy $(\sim 10 \mathrm{~kg})$ copper block. The variable junctions of the thermocouples are thermally anchored to this block. A stable temperature gradient is established between the reference junctions and variable junctions by balancing the refrigerator power from the boiling reference cryogen with the power supplied to a heater coil wound on the copper block. A manually controlled heater coil is wrapped on the lower cryostat so that the rate of boiling in the lower chamber may be increased; refrigeration from the liquid to the upper copper block is sufficient without applying external power except for the lowest temperature intervals.

The upper and lower cryostats are completely contained in a vacuum chamber. The vacuum chamber is, in turn, totally immersed in liquid nitrogen.

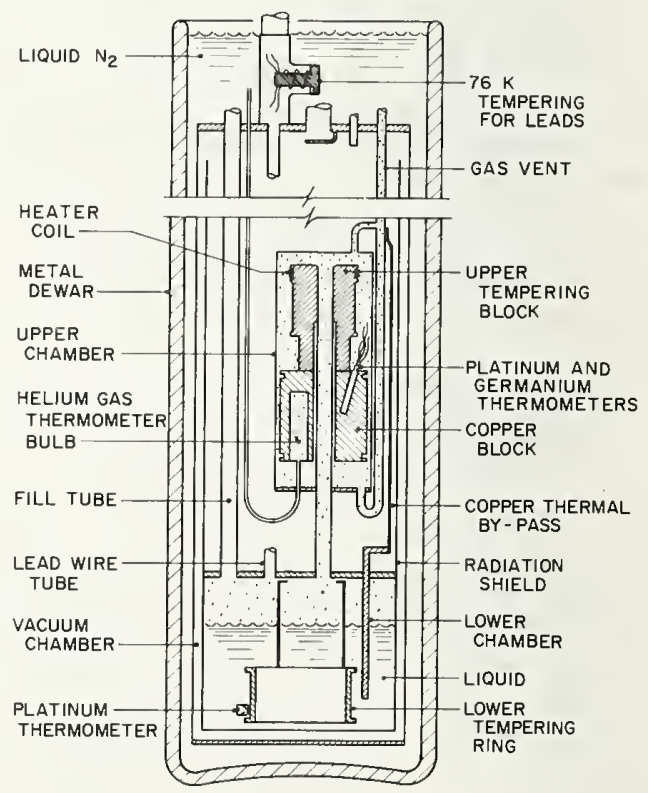

Figure 2. Schematic of thermocouple calibration cryostat. 
In addition to the vacuum insulation and liquid nitrogen shield, radiation shields have been wrapped on the upper and lower chambers and on the inner surface of the vacuum chamber. The radiation shields consist of layers of aluminum foil separated by balsa wood strips. The insulating vacuum is maintained at approximately $5 \times 10^{-6}$ torr by a $20 \mathrm{\ell} / \mathrm{s}$. diffusion pump. All vacuum seals are made using a low melting point solder in the flange and trough arrangement shown in figure 3 . The outer vacuum chamber seal is effective at $\sim 76 \mathrm{~K}$, while the seals on the two inner cryostats are used down to $4 \mathrm{~K}$. Seals of this sort require no heavy flange and are made at low enough temperatures that there is little danger of overheating nearby primary thermometers. Care must be taken, however, to center the cup and lip. If either the eup or lip is out of round, differential contraction can cause cracks in the seals at low temperatures.

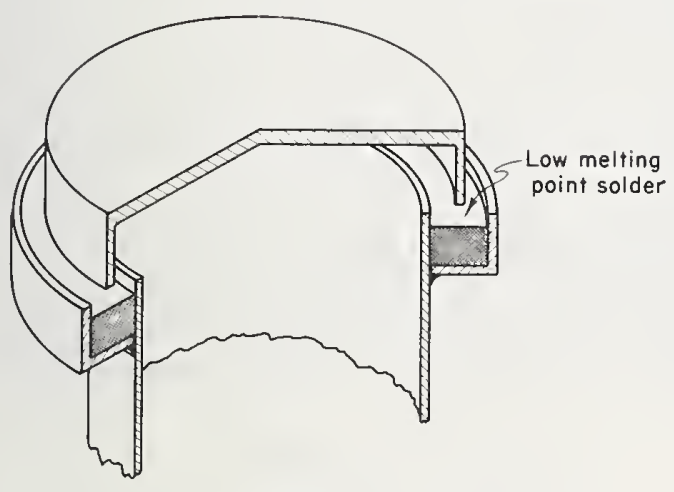

Figure 3. Flange and trough arrangement for using low melting point solder to make cryogenic vacuum seals.

It is imperative that the upper chamber is isothermal; temperature fluctuations of the variable junction of the thermocouples have to be minimized, since approximately one hour is required to make the necessary measurements at each temperature gradi. ent. Energy flow into the upper chamber is controlled as follows: (1) All wires eoming into the system are first brought to $76 \mathrm{~K}$ by thermal attachment to the liquid nitrogen shield. They are then thermally anchored in the reference liquid before going into the upper chamber. (2) The gas vent line for the inner chambers is in the proximity of the upper chamber. Since the vent line is in contact with the liquid nitrogen shield, it could be warm relative to the temperature of the upper chamber. A heavy copper thermal bypass was installed to transfer any excess energy to the reference liquid in the lower chamber without coming near the upper chamber. (3) Rardiative heat transfer to the copper bloek is ressentially eliminated by plaeing a eoncentric thermal shield between the block and the walls of the upper cryostat. The tem. perature of the shield is regulated by supplying current to a heater coil on the upper chamber walls. The temperature difference between the block and shield was never greater than $0.01 \mathrm{~K}$ while taking the data reported in this monograph.

The temperatures of the variable junction bloek and of the thermal shield surrounding the block are controlled automatieally. The controllers used are solid state devices designed specifically for low power (10 watts maximum), high stability applieations. For the block heater, either a platinum or germanium resistance thermomcter is used as a sensor. A bucking voltage corresponding to the desired thermometer resistance is set on a potentiometer; the controller senses the misbalanee between the potentiometer setting and the thermometer voltage and supplies power to the block heater until a null situation is achieved. The temperature drift of the block during a one hour run is nominally between 3 and 5 millikelvin $(\mathrm{mK})$. A separate power supply is used for the shield heater; its control sensor is a four-junction differential thermopile between the block and the shield.

The pressure above the reference cryogen is manostatically controlled [3] when using liquid hydrogen or liquid nitrogen. Pressure control is such that the temperature drift of the reference liquid is less than 3 $\mathrm{mK} / \mathrm{h}$, as determined from readings of a calibrated platinum resistance thermometer in the reference liquid. This temperature stability corresponds to less than $0.5 \mathrm{~mm}$ pressure drift during the one hour runs. When liquid helium is used as the reference liquid, the system is opened to atmospheric pressure and the temoerature is determined by reading the barometric pressure. The maximum pressure variations observed during a single testing period of one hour are usually less than $0.9 \mathrm{~mm}$, which corresponds to a temperature change of $1.4 \mathrm{mK}$ in the liquid helium reference bath [4].

Two types of resistanee thermometers are used to determine the temperature of the variable junctions of the thermocouples. Capsule type platinum resistance thermometers are used between 20 and $280 \mathrm{~K}$ : germanium resistance thermometers are used below $20 \mathrm{~K}$. Three thermometers of each type are usually inserted in the copper block. The thermal resistance between the thermometers and the block is reduced by wrapping 


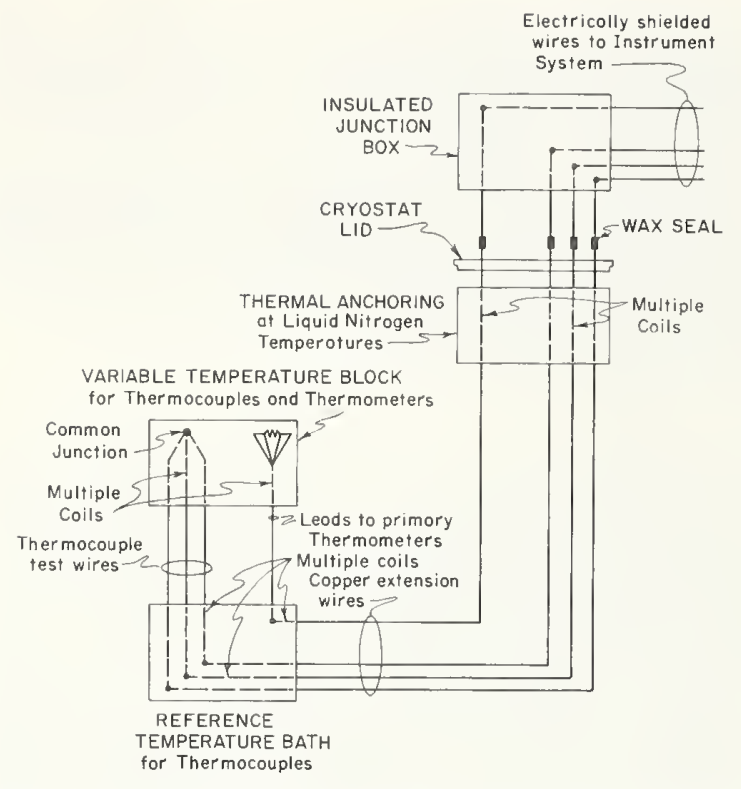

FIGURE 4. Schematic of thermal and electrical placement of thermometers in the calibration system.

each thermometer with $0.025 \mathrm{~mm}$ aluminum foil and then removing layers of foil one at a time until a snug fit is obtained between the thermometers and the thermometer wells. For this research, one thermometer of each type was calibrated at NBS-Washington. The ice-point resistance, $R_{0}$, for the platinum thermometer was carefully determined by measurement at the triple point of water $[5,6,7]$. The NBS-Washington calibration was then adjusted to account for the precise value of $R_{0}$, as measured with our bridge [8]. The two remaining thermometers of each type are used as sensors for the heater control system and as checks on the primary thermometers

The schematic given in figure 4 illustrates the electrical and thermal placement of the thermocouple test wires. The room temperature segments of the copper wires enter the system through a wax seal. The tem. perature of the wires is subsequently reduced to liquid nitrogen temperature by wrapping on an $11 \mathrm{~mm}$ diameter copper rod which is in intimate contact with the liquid nitrogen shield. The wires are then drawn into the reference liquid in the lower chamber. Approximately one meter of each wire is wrapped on the copper cylinder below the reference cryogen level in the lower chamber. This is done to ensure that the wires are at the temperature of the reference liquid before being taken into the upper chamber. The wires are then taken into the upper chamber via the thermal stand-off tube connecting the chambers. Approximately one meter of each wire is wrapped on the upper tempering block. The thermocouple test wires are similarly anchored to the variable temperature block and to a short cylinder in the reference liquid. The thermocouple reference junctions are made by spot welding the copper extension wires to the thermocouple test wires. It is important to note that thermal gradients across the junctions (both variable and reference) are minimized by carefully bringing all wires to the same temperature before the junctions are made.

As mentioned above, a fixed length of one meter of wire was used to thermally anchor the wires at various temperatures. A thermal analysis based on Hust's [9] method indicates that this length is more than should be necessary even under more unfavorable conditions. However, since our thermocouple test wires had various diameters, thermal conductivities, and insulations, we used a conservatively calculated length.

As shown in figure 4 , all of the thermocouple test wires come together to form a single junction in the variable temperature chamber. This junction is thermally tied to the copper block, but is electrically insulated from it. The reference junctions in the lower chamber are electrically insulated from one another and are in thermal contact with the reference liquid. There are actually 19 thermocouple test wires in the system during the calibration.

A block diagram of our measurement system is given in figure 5. The output of the various thermometers in the cryostat is fed into a bank of switches labeled THERMOMETER SELECTOR SWITCH in this diagram. The signal from the thermometer or thermometers we wish to monitor is transferred from the thermometer selector switch to another bank of switches labeled INSTRUMENT SELECTOR SWITCH. These switches allow the thermometer signal to be measured on the appropriate instrument. Both the THERMOMETER SELECTOR SWITCHES and the INSTRUMENT SELECTOR SWITCHES are multichanneled, i.e., more than one incoming thermometer signal can be directed to the proper instrument at any

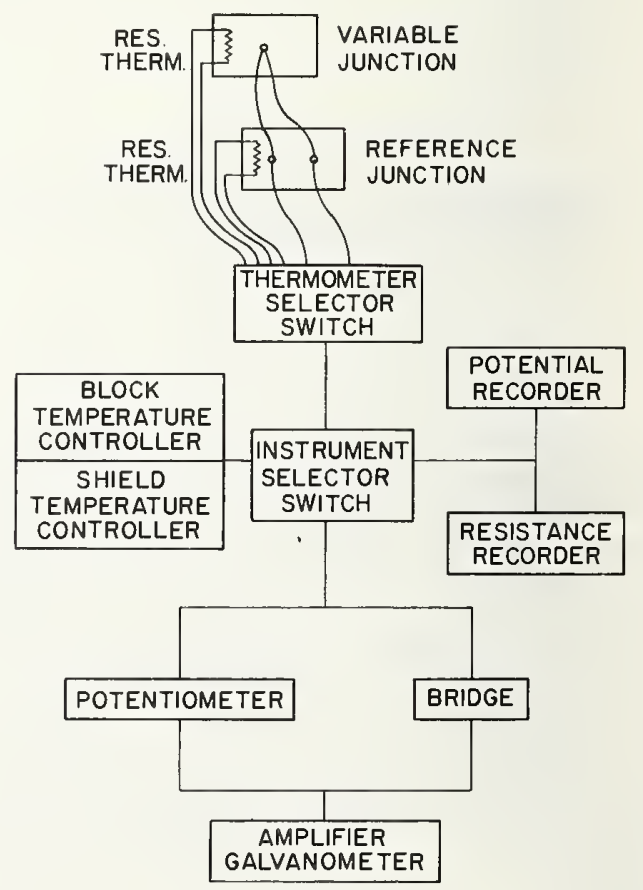

Figure 5. Block diagram of thermocouple calibration instrumentation. 
one time. The switches uscd in the sensitive circuits are of the low-thermal, rotary type. All switch banks 'xtilize solder which matches copper thermoelectrically and are shielded by $\sim 0.6 \mathrm{~cm}$ thick iron boxes packed with glass fibers. These procedures substantially reduce the spurious thermal voltage effects at the switches.

The instruments indicated in figure 5 are as follows:

(1) The potentiometer is a six dial device with a resolution of $0.01 \mu \mathrm{V}$. The limit of error for this instrument is 0.01 percent of reading, plus $0.02 \mu \mathrm{V}$. The potentiometer was calibrated at NBS-Boulder prior to the tests. The unsaturated cadmium sulfate standard cell used with this potentiometer was also calibrated in Boulder prior to the tests. The potentiometer is used to measure the thermocouple output, germanium resistance thermometer voltage, and standard resistor voltages.

(2) The bridge is a type G-2 Mueller bridge. The bridge reads directly $100.0001 \Omega$, and interpolation on the galvanometer allows two additional figures in precision. The bridge was calibrated in our laboratory [10] prior to the tests. We found it necessary to pro. vide thermal isolation for the bridge in order to achieve the precision mentioned above. The thermal isolation consists of encasing the entire bridge in a metal box with about $2.5 \mathrm{~cm}$ plastic foam completely surrounding the bridge; remote dial manipulations are accomplished by plastic extensions from the bridge dials.

(3) An electronic amplifier galvanometer is used with both the Mueller bridge and with the potentiometer.

(4) The potential and resistance recorders shown are used to monitor the system during cooldown and to roughly indicate when a stable temperature gradient has been established between the upper and lower thermocouple junctions.

\section{Experimental Design and Technique}

Our method of data acquisition is designed to take advantage of the large amount of partially redundant information available. The common junction allows many different combinations to be measured. Concepts derived by analogy from the connectivity of paths in graph theory are used to determine optimum experimental procedures $[11,12,13]$. As a simple illustration of how graph theory is applied, consider the situation where one is to intercompare some property of two different objects where two other intermediate objects are also available. Graphically this situation can be represented as in figure 6 . In this figure, the objects

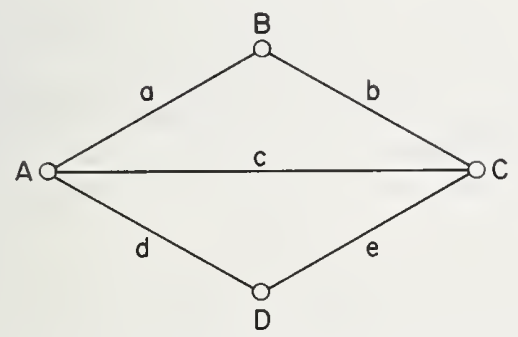

Figure 6. Four object measurement graph.

are represented by the vertices and the comparison of some property between objects is represented by the connecting lines. For example, the comparison $a$ might represent the difference in weight between objects $A$ and $B$. In applying graph theory to thermoelectric measurements, the vertices represent the thermocouple test wires and the connecting lines represent the thermal voltages generated by a given temperature gradient. The thermoelectric voltage between $A$ and $C$ in figure 6 would be determined by (1) measuring $c$, that is, a direct measurement of the desired voltage, (2) measuring the thermal voltages $a$ and $b$ and combining these data algebraically, and (3) measuring the thermal voltages $d$ and $e$ and similarly combining these data. The algebraic combination of $a+b$ and $d+e$ yield two independent determinations of the desired voltage, equivalent to $c$. The final determination of the voltage $(A-C)$ is given by

$$
e_{\mathrm{calc}}=(A-C)=[2 c+(a+b)+(d+e)] / 4 .
$$

The measurement $c$ is given a weight of 2 , since it involves only one experimental determination, whereas the other two measurement paths both require two readings. The estimate of the standard deviation for $(A-C)$ is given by

$$
\begin{aligned}
S^{2}=\left\{2\left(e_{\mathrm{calc}}-c\right)^{2}+\left[e_{\mathrm{calc}}-\right.\right. & (a+b)]^{2} \\
& \left.+\left[e_{\mathrm{calc}}-(e+d)\right]^{2}\right\} / 3 .
\end{aligned}
$$

The advantages of taking data in this way are that it randomizes potentiometer dial errors, eliminates any subconscious operator prejudice, and randomizes spurious voltages in the lead wires. The magnitudes of $a, b, c, d$, and $e$ usually vary considerably; this means that the potentiometer dial settings are also considerably different. Any dial errors which exist are randomized by this method. These random errors would then appear as scatter in the data and would be accounted for in the variance calculated from eq. (2).

Since the potentiometer dial readings vary a great deal and the order of readings may be random, the chance for subconscious operator prejudice is minimized. In order to influence the readings in a systematic way, the operator would have to algebraically combine very different numbers which are not necessarily taken in adjacent readings. This is not done subconsciously, even on the simple four object system being considered here. On the other hand, if multiple readings are taken of the same quantity, there is a strong tendency to produce data which are biased in a systematic way. 
Spurious voltages in the extension wires are also randomized by using the graph theory method. Consider a three wire system such as that which would result if the $D$ wire were eliminated from figure 6 . Assume the number we actually want is $(B-C)$. This is the thermoelectric voltage generated by the thermocouple made from materials $B$ and $C$ when a thermal gradient, $\Delta T=T_{1}-T_{2}$, exists. The number which is actually measured is $b$ which includes the spurious voltages generated in the extension wires to both $B$ and $C$. If the spurious voltages $\delta_{B i}$ and $\delta_{C i}$ are zero or are at least known, then the true value of $(B-C)$ may be determined. The voltages $\delta_{B i}$ and $\delta_{C i}$ can be determined by an isothermal test where $T_{1}=T_{2}$. When $T_{1}=T_{2},(B-C)=0$ and $b=(B-C)+\delta_{B i}+\delta_{C i}=\delta_{B i}+\delta_{C i}$. However, this determination of the spurious voltages is valid only when the thermal gradients in the system are the same as when the isothermal test was made. In many experimental situations this approach to the spurious voltage problem is not practical. The only other solution is to randomize these voltages so that they appear as scatter in the experimental data and are therefore included in the estimate of the variance, $S^{2}$. The graph theory approach does allow these voltages to be randomized. Suppose, for instance, that we wish to determine $(B-C)$ in figure 6 . The voltages $a$, $b$, and $c$ would then be measured.

$$
\begin{gathered}
a=(B-A)+\delta_{A 1}+\delta_{B 1} \\
b=(B-C)+\delta_{B 2}+\delta_{C 1} \\
c=(A-C)+\delta_{A 2}+\delta_{C 2} \\
b_{\mathrm{calc}}=\left[b+\frac{1}{2}(a+c)\right] / 3 / 2=\frac{2 b+a+c}{3} \\
b_{\mathrm{calc}}=\frac{[2(B-C)+(B-A)+(A-C)]}{3} \\
+\frac{\delta_{A 1}+\delta_{A 2}+\delta_{B 1}+2 \delta_{B 2}+2 \delta_{C 1}+\delta_{C 2}}{3} .
\end{gathered}
$$

If the spurious conditions are stable, i.e., the measurements are made rapidly enough that the system gradients haven't changed,

$$
\begin{aligned}
& \text { then } \delta_{A}=\delta_{A 1}=\delta_{A 2}, \delta_{B}=\delta_{B 1}=\delta_{B 2}, \text { and } \delta_{C}=\delta_{C 1}=\delta_{C 2} \\
& \text { and } b_{\text {calc }}=\frac{[2(B-C)+(B-A)+(A-C)]}{3}
\end{aligned}
$$$$
+\frac{2}{3} \delta_{A}+\delta_{B}+\delta_{C}
$$

If the more common procedure of multiple readings of $b$ were used, $b$ would be measured, say, 3 times:

$$
\begin{aligned}
& b_{1}=(B-C)_{1}+\delta_{B}+\delta_{C}, \\
& b_{2}=(B-C)_{2}+\delta_{B 1}+\delta_{C 1}, \\
& b_{3}=(B-C)_{3}+\delta_{B 2}+\delta_{C 2}, \text { and }
\end{aligned}
$$

$$
\begin{aligned}
b_{\mathrm{calc}}=\frac{\left[(B-C)_{1}+(B-C)_{2}+(B-C)_{3}\right]}{3} \\
+\frac{\delta_{B}+\delta_{C}+\delta_{B 1}+\delta_{C 1}+\delta_{B 2}+\delta_{C 2}}{3}
\end{aligned}
$$

Again, assume stable spurious conditions for the time required to determine $b$ three times. Then $\delta_{B}=\delta_{B 1}=$ $\delta_{B 2}, \delta_{C}=\delta_{C 1}=\delta_{C 2}$, and $b_{\text {calc }}=(\overline{B-C})_{1,2,3}+\delta_{B}+\delta_{C}$. The tendency to randomize dial errors and to eliminate operator prejudice is illustrated by comparing $b_{\text {calc }}$ from the graph theory method and from the multiple readings method. More dials are probably changed in determining $(B-C),(B-A)$, and $(A-C)$ than are changed in determining $(B-C)$ three times. The subconscious operator prejudice is reduced by having to combine the two readings $(B-A)$ and $(A-C)$ to get the independent determination of $(B-C)$.

The third and perhaps the most important advantage of the graph theory approach to the measurement of thermocouple outputs is the randomization of spurious voltages in the extension wires. These errors would not be accounted for, i.e., they would be systematic, if the multiple reading approach is utilized. This is shown in the calculation of the estimate of variance for the two methods:

Graph theory:

$$
\begin{aligned}
& b_{\text {ca lc }}= \frac{[2(B-C)+(B-A)+(A-C)]}{3} \\
&+\frac{\delta_{A 1}+\delta_{A 2}+\delta_{B 1}+2 \delta_{B 2}+2 \delta_{C 1}+\delta_{C 2}}{3} \\
& S_{b_{\text {calc }}=\left\{2\left(b_{\text {calc }}-b\right)^{2}+\left[b_{\text {calc }}-(a+c)\right]^{2}\right\} / 2}
\end{aligned}
$$

now assume that the only cause of variation is the spurious voltages

$$
S_{b_{\mathrm{calc}}}^{2}=1 / 3\left(\delta_{A^{\prime}}+\delta_{B^{\prime}}-\delta_{C^{\prime}}\right)^{2}
$$

where $\delta_{A^{\prime}} \equiv \delta_{A 1}+\delta_{A 2}$,

$$
\begin{aligned}
& \delta_{B^{\prime}} \equiv \delta_{B 1}-\delta_{B 2}, \text { and } \\
& \delta_{C^{\prime}} \equiv \delta_{C 1}-\delta_{C 2} .
\end{aligned}
$$

If spurious conditions are constant, $\delta_{B^{\prime}}=0, \delta_{C^{\prime}}=0$ and $S_{b_{\mathrm{calc}}}^{2}=1 / 3 \delta_{A^{\prime}}{ }^{2}$.

Multiple measurements:

$$
\begin{array}{r}
b_{\text {calc }}=\frac{\left[(B-C)_{1}+(B-C)_{2}+(B-C)_{3}\right]}{3} \\
+\frac{\delta_{B}+\delta_{C}+\delta_{B 1}+\delta_{C 1}+\delta_{B 2}+\delta_{C 2}}{3} ; \\
S_{b_{\text {calc }}=\left\{\left(b_{\text {calc }}-b_{1}\right)^{2}+\left(b_{\text {calo }}-b_{2}\right)^{2}+\left(b_{\text {calc }}-b_{3}\right)^{2}\right\} / 2}
\end{array}
$$




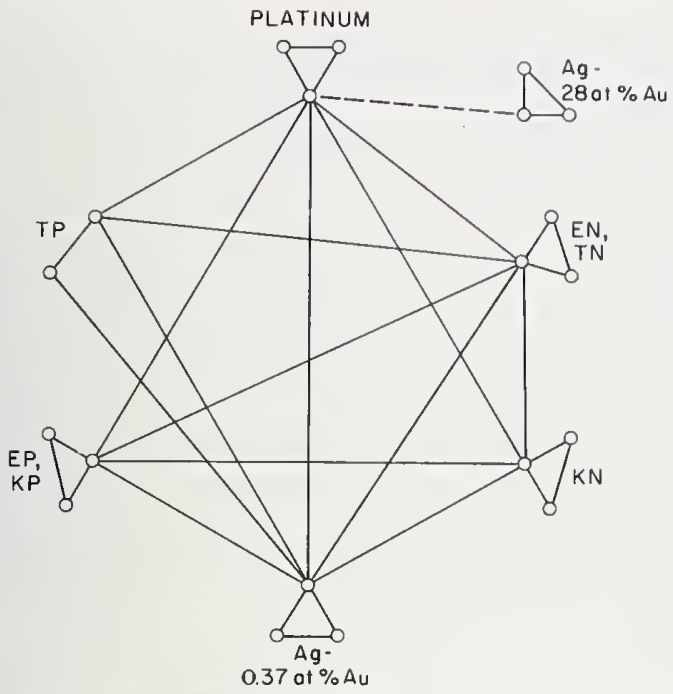

FIGURE 7. Measurement graph used for calibration of thermocouple materials TP, KP (or EP), KN,TN (or EN), Pt, Ag-0.37 at\% $\mathrm{Au}$, and $\mathrm{Ag}-28$ at\% $\mathrm{Au}$.

again assuming all seatter is due to spurious voltages, i.e.,

$$
(B-C)_{1}=(B-C)_{2}=(B-C)_{3} \text {, then }
$$

$$
\begin{aligned}
& 18 S_{b_{\mathrm{cal}}}^{2}= {\left[-2\left(\delta_{B}+\delta_{C}\right)+\delta_{B 1}+\delta_{C 1}+\delta_{B 2}+\delta_{C 2}\right]^{2} } \\
&+\left[-2\left(\delta_{B 1}+\delta_{C 1}\right)+\delta_{B}+\delta_{C}+\delta_{B 2}+\delta_{C 2}\right]^{2} \\
&+\left[-2\left(\delta_{B 2}+\delta_{C 2}+\delta_{B}+\delta_{C}+\delta_{B 1}+\delta_{C 1}\right]^{2} .\right.
\end{aligned}
$$

Now if the spurious conditions are eonstant $\delta_{B}=$ $\delta_{B 1}=\delta_{B 2}, \delta_{C}=\delta_{C 1}=\delta_{C 2}$, and $S_{b_{\mathrm{calc}}}^{2}=0$.

The spurious voltages do not appear in the estimate of the standard deviation when the multiple measurement method is used. They are present but unaeeounted for until some estimate of systematie error is introduced.

The graph used to represent the measurements made on thermocouple materials TP, TN(EN), $\mathrm{KP}(\mathrm{EP}), \mathrm{KN}, \mathrm{Pt}, \mathrm{Ag}-0.37$ at $\% \mathrm{Au}$, and $\mathrm{Ag}-28$ at $\% \mathrm{Au}$ is given in figure 7 . The terminology diseussed earlier in this section applies to this figure, i.e., materials are represented by the vertices and thermovoltage measurements are represented by lines. The dashed line connecting platinum and $\mathrm{Ag}-28$ at $\%$ Au indieates that eomparison was made in a scparate calibration. This was neeessary because the optimum $A g$ - $A u$ alloy had not been reeeived at the time the original calibration was done. $A$ detaited diseussion of how these data were treated is eontained in the DATA ANALYSIS seetion of this report.

Each of the measurements indicaterl in figure 7 was made at sixty-eight different temperature intervals, 19 in the liquid helium range ( $4 \mathrm{~K}$ to $25 \mathrm{~K}$ ), 17 in the liquid hydrogen range ( $19 \mathrm{~K}$ to $90 \mathrm{~K}$ ), and 32 in the liquid nitrogen range ( $75 \mathrm{~K}$ to $290 \mathrm{~K}$ ). The 11 umber of temperature intervals in eaeh range was as above for the $\mathrm{Pt}$ versus $\mathrm{Ag}-28$ at $\% \mathrm{Au}$ eombination ałso, even though the individual intervals were not exactly the same.

During the eourse of making the measurements, the current of the potentiometer was eheeked before eaeh set of thermoeouple readings, e.g., prior to reading thermoeouples $1,8,15$, ete. This was donc to minimize the effeet of ehanging potentiometer standard eurrent due to battery drift. The bridge zero of the Mueller bridge was determined before and after each temperature gradient sequenee.

When operating with liquid nitrogen and liquid hydrogen, the temperature of the variable junction was measured three times during eaeh run. These determinations were made at the beginning, near the middle, and at the eonclusion of eaeh run. The 3 to $5 \mathrm{mK}$ drift during eaeh run was suffieiently small and linear to allow the true variable temperature of each thermoeouple to be approximated. The reference temperature was determined six times during the course of eaeh run. The bath temperature was adjusted to be very near $20 \mathrm{~K}$ and $75 \mathrm{~K}$ for liquid hydrogen and liquid nitrogen, respeetively, by eontrolling the pressure over the bath liquid. The aetual referenee temperature for the individual thermoeouples was determined by linear interpolation.

The exaet time of eaeh of the primary temperature determinations was reeorded during each run. Periodieally, the time for eaeh step of a run was reeorded. After several of these runs, it was elear that the variation of time between a given thermocouple voltage determination and the primary temperature determination was very nearly eonstant. This information and the ehronologieal data for the primary temperature measurements from all tests allowed the variable and referenee temperatures to be determined for each partieular thermoeouple. The temperatures determined in this way minimized the effect of junction temperature drift.

\section{Data Analysis}

Two major steps were needed to transform the experimental data from its original form into its final form. The first operation involved making minor adjustments to the data and forming the desired thermoeouple eombinations using graph theory eonsiderations. The seeond step eonsisted of finding the best analytical representation of the adjusted data and calculating statistieal quantities sueh as preeision, skewness and elongation.
The first operation on the data was to apply potentiometer dial eorreetions to all voltage data and to apply Mueller bridge dial eorreetions to all resistance data. The eorrected resistanees were used to determine the temperature of the primary platinum thermometer by linear interpolation in the resistanee versus temperature tables. The tables used have temperature inerements of $1 \mathrm{~K}$ from $90 \mathrm{~K}$ to $300 \mathrm{~K}$ and $0.1 \mathrm{~K}$ from $14 \mathrm{~K}$ to $90 \mathrm{~K}$. The error introdueed by linear interpolation 
in these tables is less than $0.1 \mathrm{mK}$ above $28 \mathrm{~K}$ and less than $0.4 \mathrm{mK}$ below $28 \mathrm{~K}$. The platinum thermometers had been calibrated by members of the Temperature Section, NBS-Washington, using the IPTS-48 and NBS.55 scales; we later updated the calibrations to the IPTS-68 scale [14].

A calibrated germanium resistance thermometer was used to determine variable junction temperatures in the range from $4 \mathrm{~K}$ to $20 \mathrm{~K}$. The thermometer current was determined by measuring the voltage across a standard resistor which was in series with the thermometer. Corrected voltages from the thermometer and from the standard resistor were used to determine the resistance of the thermometer. A power series representation of $T=f(R)$ for our thermometer was used to determine the temperature. The germanium thermometer had been calibrated by members of the Cryogenic Physics Section in NBS-Washington, using the NBS P 2-20 (1965) scale [14].

As discussed in the previous section the time sequence of primary temperature determinations and thermocouple readings was known. Using this information, it was possible to determine the variable and reference temperatures which actually existed at the time the thermocouple voltages were measured. However, in order to take advantage of the graph theory approach to data acquisition, it was necessary that all combinations have the same reference temperature and the same variable junction temperature. Linear interpolation in the $E_{i}$ versus $T_{i}$ data for each thermocouple combination was used to adjust the variable junction temperature of each thermocouple to the average of the values which are taken for each gradient. An analytic fit of the data near the reference temperature is used to determine the $d E_{i} / d T$, necessary to make the small correction which adjusts all reference voltages to the voltage equivalent of $4 \mathrm{~K}$, $20 \mathrm{~K}$, or $75 \mathrm{~K}$ reference temperatures.

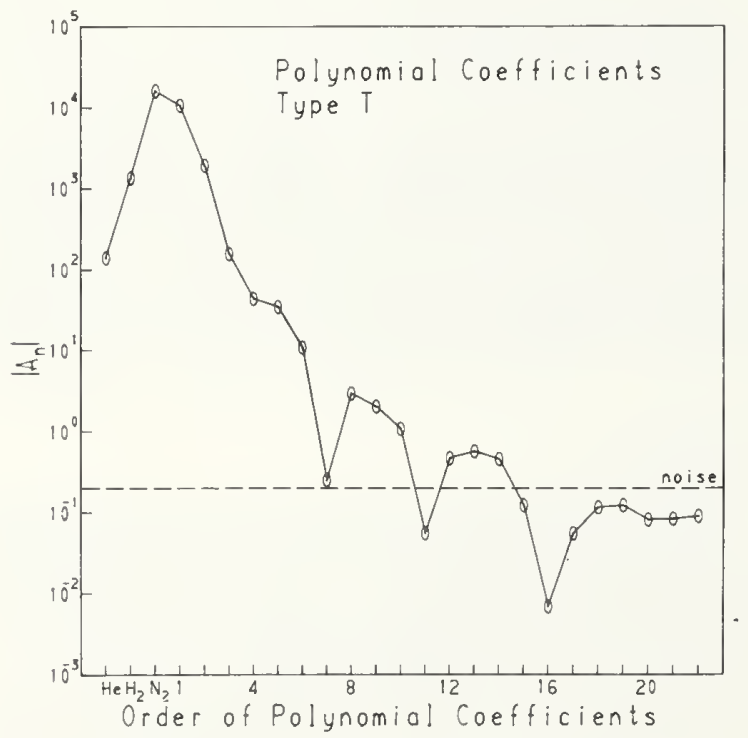

Figthe 8. Graph of $\left|A_{n}\right|$ versus number of coefficients for thermocouple Type $T$.
After these corrections and adjustments have been made, the data represent the thermoelectric voltages of the desired thermocouple combinations with identical reference temperatures and identical variable temperatures. Graph theory manipulations were then performed with these data to obtain multiple indirect determinations of a given thermal voltage. The general procedure for calculation of thermal voltages is similar to that given in the previous discussion of graph theory.

The next major step in the data analysis is to fit the experimental data in order to provide a continuous $E=f(T)$ relationship for each thermocouple combination. The method used to represent the data is a modified Gram-Schmidt approximation $[15,16]$. The calculated values for the voltages of each thermocouple combination were approximated by a series of orthonormal polynomials in the $L_{2}$ norm (least squares), that is,

$$
E(T)=\sum_{n=1}^{L} A_{n} F_{n}(T)
$$

where

$E(T)=$ thermocouple potential in microvolts;

$T \quad=$ temperature in degrees Kelvin;

$L \quad=$ the highest order fit-an order high enough to represent the data with no loss of precision, but not so high as to introduce mathematical oscillations;

$A_{n} \quad=$ constants to be determined by the fitting approximations; and

$F_{n}(T)=$ orthonormal polynomials, orthonormal on the data points over the range of variation of the independent variable, $T$.

The orthonormal polynomials are taken to be the truncated power series

$$
F_{n}(T)=\sum_{j=1}^{n} C_{n} T^{j}
$$

where the $C_{n j}$ are determined from the orthonormality conditions at the measured temperatures. It should be stressed that the $F_{n}$ are determined by the values of the independent variable $T$ only. The $F_{n}(T)$ are therefore the same for all thermocouple combinations which are based on the same set of temperatures. All of the data for the solid line measurements in figure 7 are based on the same set of temperatures. The dashed line measurement, being from a second set of calibrations, is based on another set of temperatures. Rather than provide two sets of orthonormal polynomials, interpolations in the second set of data were done to provide the $E_{i}, T_{i}$ data for Pt versus Ag-28 at $\% \mathrm{Au}$ at the temperatures used in the first calibration. Third and fourth order interpolations were sufficient to convert the second calibration data to the temperatures of the first calibration within the precision of the data. 
There is, therefore, a single set of orthonormal polynomials for all of the data being reported herc. The coefficients $A_{n}$ are determined by minimizing the sum of the squared deviations in $E$ and are different for each thermocouple combination. The highest order, $L$, also differs from combination to combination.

A common problem in the numerical analysis of data fitting by polynomials is selection of the proper order-an order high enough to represent the data with no loss of precision, but not so high as to introduce mathematical oscillations. This problem is well solved by the method of fitting with orthonormal polynomials. The absolute values of the coefficients $A_{n}$ decrease with increasing $n$ as long as they are larger than the noise level. However, when the noise level is reached the coefficients are random valued. An inspection of a graph of $\left|A_{n}\right|$ versus number of terms $(n)$ shows the noise level and the probable maximum value of $n$ that is significant. In figure $8,\left|A_{n}\right|$ versus $n$ is shown for thermocouple Type T. The coefficient for order 11 is accidentally below the noise level of $2 \times 10^{-1}$. The first three points in the figure are called the range shift constants. As mentioned previously, our data are taken using three different reference temperatures; the range shift constants plotted in figure 8 are used to adjust these reference tempera. tures to a common value. Figure 9 shows a least squares approximation to the experimental data for thermocouple Type $\mathrm{T}$ before the range shift constants are applied. The necessary shifts are determined by using the principle of successive temperatures [17]. This principle may be illustrated by considering two dissimilar homogeneous metals which produce a thermal voltage of $E_{1}$ when the junctions are at temperatures $T_{1}$ and $T_{2}$ and a thermal voltage of $E_{2}$ when the junctions are at tempcratures $T_{2}$ and $T_{3}$. The thermal voltage generated when the junctions are at temperatures $T_{1}$ and $T_{3}$ will be $E_{1}+E_{2}$.

Another advantage of the orthonormal polynomial representation is that the function may be simplified by lowering the order of the fit without having to determine new $A_{n}$. A quantitative discussion of errors associated with reduced order fits and with reduced num-

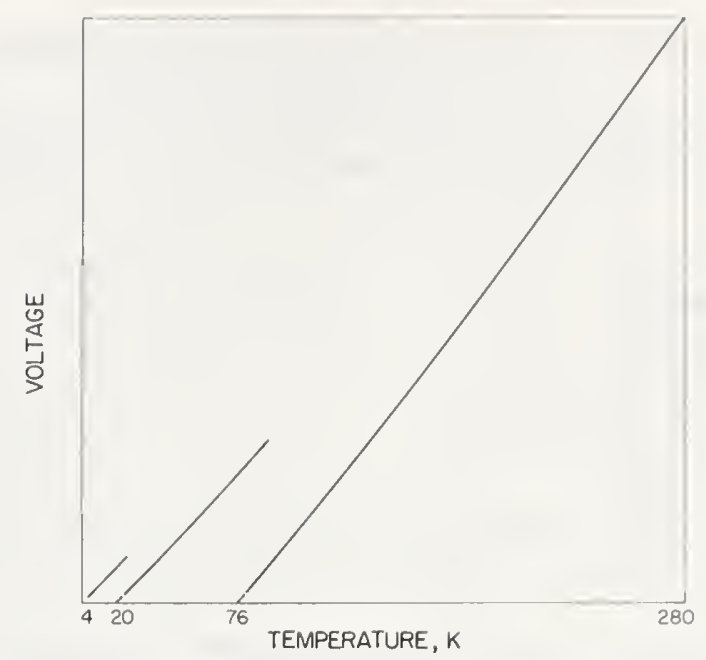

Figure 9. Least squares approximations to typical data before the range shift constants are applied.

ber of significant figures is given in the STANDARD TABLES AND FUNCTIONS section.

As a convenience to users who wish to use the highest order, and therefore highest precision, fit for a particular thermocouple combination, the orthonormal polynomials and coefficients have been combined to give simple power series coefficients. The power series method of generating the standard data is more straight forward to program for a computer, since it involves only one summation. Using the power series coefficients, the $E=f(T)$ relationships are given by

$$
E=\sum_{j=0}^{L} B_{j} T^{j}
$$

It should be stressed that the full array of coefficients must be used in the power series method, whereas in the orthogonal representation each order is independent.

\section{Error Analysis}

The estimate of variance used in the first stage of our data analysis was arrived at by using the direct measurement and the various indirect measurements:

$$
S^{2}=\frac{\alpha\left(E_{\text {calc }}-E_{\text {direct }}\right)^{2}+\left(E_{\text {cale }}-E_{\text {indirect }(1)}\right)^{2}}{+\left(E_{\text {calc }}-E_{\text {indirect }(2)}\right)^{2}}
$$

where $\alpha$ is a weighting factor. The direct and indirect measurements were weighted to account for the actual number of cxperimental determinations used to make up each indirect voltage.

In the curve fitting part of the analysis, the precision of the analytical approximation of the data was needed. Again, precision is determined by the estimate of the variance. The coefficients, $A_{n}$, and the standard devia-

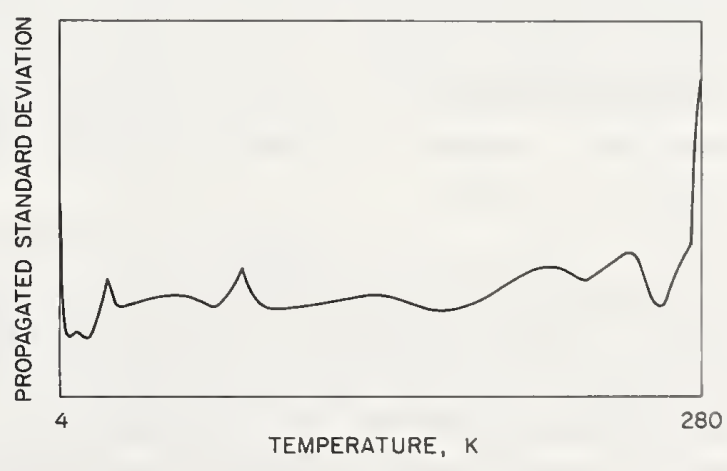

Figure 10. Characteristic propagated standard deviation $\left(\sigma_{E}\right)$ in voltage for the thermocouple calibrations. 
TABLE 7. Average values of the standard deviations for the main thermocouple combinations

\begin{tabular}{l|c}
\hline \multicolumn{1}{c|}{ Thermocouple material } & $\sigma_{E}(\mu \mathrm{V})$ \\
\hline Type E & 0.12 \\
Type K & 0.08 \\
Type T. & 0.06 \\
Pt versus Ag-28 at\% Au L & 0.06 \\
Pt versus TN & 0.12 \\
Ag-28 at\% Au versus TN & 0.13 \\
\hline
\end{tabular}

tions, $\sigma_{A n}$, are available from the orthonormal fit $E(T)=f\left(A_{n}, F_{n}(T)\right)$. The estimate of the standard deviation of a predicted point $[18,19]$ is then given by

$\sigma_{E}=\left[\sum_{i=1}^{n}\left(\frac{\partial f}{\partial_{A i}} \sigma_{A_{i}}\right)^{2}\right]^{1 / 2}$

where $n=$ number of coefficients.

The $\sigma_{E}$ obtained in this way is an indication of both the scatter in the experimental data for a particular thermocouple pair and of the closeness of the fitting approximation to the experimental data. A typical example of a $\sigma_{E}$ versus temperature curve is shown in figure 10. It should be noted that the propagated standard deviation increases radically at both ends of the graph. This is partially because our input data are less precise near 4 and $280 \mathrm{~K}$. However, the upturns are caused primarily by the lack of constraints near
TABLE 8. Average values of the standard deviation of the thermocouple combinations, average values for the standard deviation of the adjustment constant, and the overall standard deviation resulting from the combined effect of these uncertainties

\begin{tabular}{l|c|c|c}
\hline \hline Thermocouple material & $\sigma_{E}(\mu \mathrm{V})$ & $\sigma_{\text {adj }}(\mu \mathrm{V})$ & $\sigma_{E, \text { total }}(\mu \mathrm{V})$ \\
\cline { 1 - 2 } & 0.10 & 0.06 & 0.12 \\
KP versus Pt_-_-_ & 0.10 & 0.07 & 0.12 \\
Pt versus TP_- & 0.10 & 0.08 & 0.13 \\
Pt versus KN__- & 0.12 & 0.06 & 0.13 \\
KP versus Ag-28 at\% Au & 0.12 & 0.07 & 0.13 \\
TP versus Ag-28 at\% Au & 0.11 & 0.08 & 0.14 \\
\hline Ag-28 at\% Au versus KN & 0.12 & & \\
\hline
\end{tabular}

the extremes, a typical characteristic encountered in curve fitting to data.

The standard deviation for each of the main thermocouple combinations is given in tables 7 and 8 . The tabular values represent averages for the entire curves; values near the extremes will usually be about twice as large.

Thermoelectric data for the thermocouple combinations listed in table 8 were obtained by the addition of shift adjustment constants to the analytical representation of the experimental data. Therefore, their total imprecision must include the imprecision of the adjustment. The total standard deviation for these combinations is calculated from

$$
\sigma_{E, \text { total }}=\left[\sigma_{E}{ }^{2}+\sigma_{\mathrm{adj}}{ }^{2}\right]^{1 / 2} \text {. }
$$

TABLE 9. Estimates of systematic errors in temperature measurements

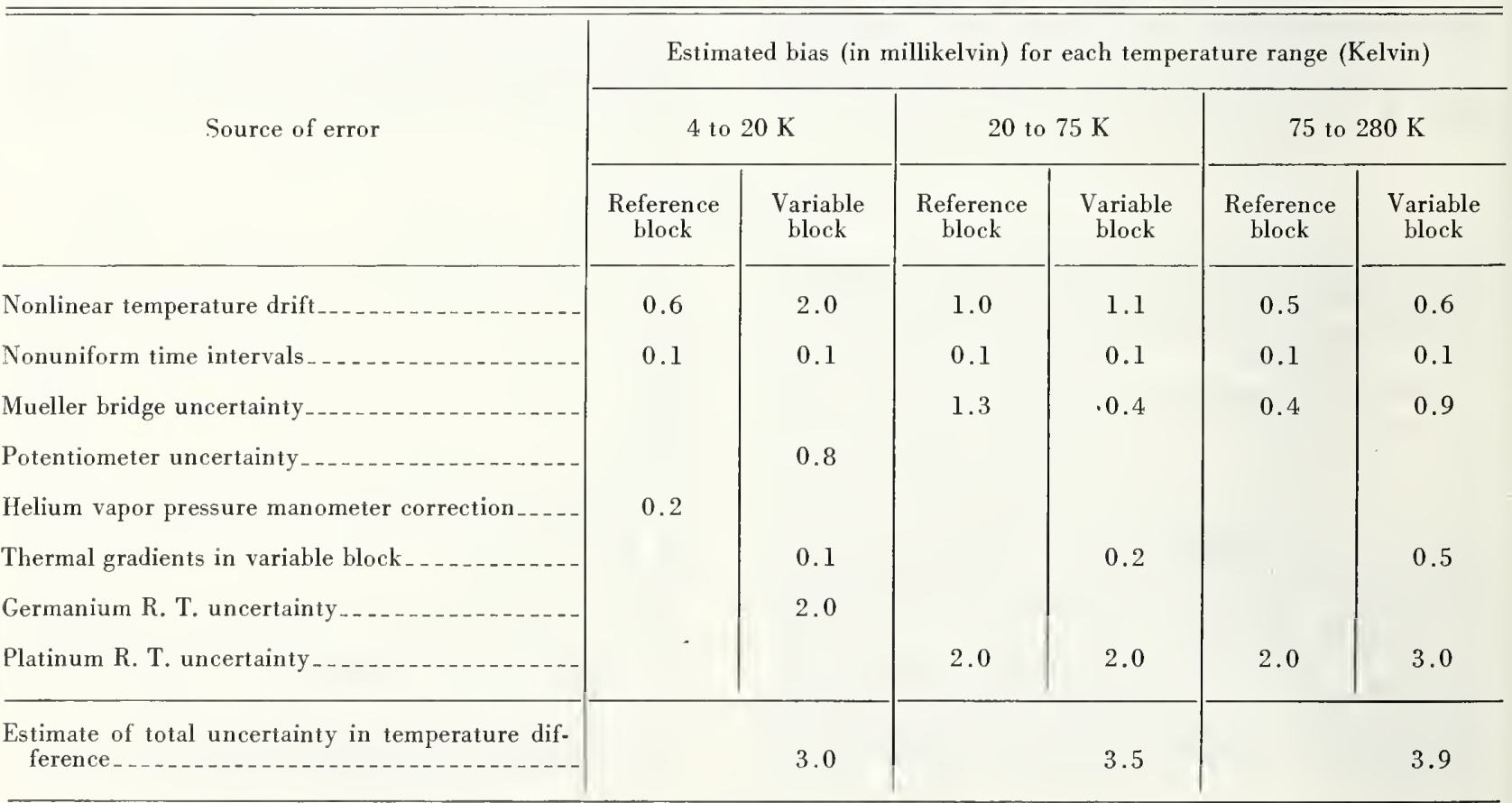


TABLE 10. Estimated systematic errors in thermocouple voltage readings

\begin{tabular}{|c|c|c|c|}
\hline \multirow{2}{*}{ Thermocouple material } & \multicolumn{3}{|c|}{ Estimated systematic error $(\mu \mathrm{V})$} \\
\hline & $4-20 \mathrm{~K}$ & $20-75 \mathrm{~K}$ & $75-280 \mathrm{~K}$ \\
\hline Type E_...... & 0.03 & 0.13 & 1.04 \\
\hline Type K.... & 0.02 & 0.08 & 0.70 \\
\hline Type T........ & 0.03 & 0.09 & 0.67 \\
\hline Pt versus $\mathrm{KN}_{-}$ & 0.02 & 0.07 & 0.30 \\
\hline KP versus $\mathrm{Pt}$ & 0.02 & 0.04 & 0.42 \\
\hline Pt versus TN $\ldots$ & 0.03 & 0.11 & 0.64 \\
\hline Pt versus $T P$ & 0.02 & 0.04 & 0.04 \\
\hline 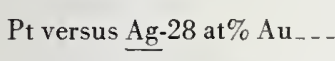 & 0.02 & 0.05 & 0.06 \\
\hline Ag- 28 at $\% \mathrm{Au}$ versus $\mathrm{KN}$. & 0.02 & 0.03 & 0.28 \\
\hline $\mathrm{KP}$ versus $\underline{\mathrm{Ag}} .28$ at $\% \mathrm{Au}$. & 0.02 & 0.07 & 0.44 \\
\hline $\mathrm{Ag}-28$ at $\% \mathrm{Au}$ versus $\mathrm{TN}_{\text {. }}$ & 0.03 & 0.04 & 0.62 \\
\hline TP versus $\underline{A g}-28$ at $\%$ Au & 0.03 & 0.03 & 0.07 \\
\hline
\end{tabular}

Values for the initial $\left(\sigma_{E}\right)$, adjustment $\left(\sigma_{\text {adj. }}\right)$, and total $\left(\sigma_{E \text {,total }}\right)$ standard deviations for these combinations are given in table 8.

The systematic errors, unlike the random errors or imprecision, can only be estimated from a knowledge of the system. The main possible sources of systematic error in the determination of the independent variable, $T$, are as follows: (1) deviation from linear temperature drift during the course of a single run, (2) nonuniform time intervals between thermocouple voltage readings, (3) Mueller bridge bias that remains or occurs after the calibration, (4) similar potentiometer errors, (5) platinum resistance thermometer calibration errors, (6) similar germanium resistance thermometer errors, and (7) thermal gradients in the variable temperature block. Our estimates of these errors are given in table 9. The quoted uncertainties do not include the systematic errors caused by disagreement between the International Practical Temperature Scale and the true thermodynamic scale. These errors are estimated to be about $2 \mathrm{mK}$.

There are three main sources of systematic error in
Table 11. Total uncertainties in thermocouple calibrations

These data include all random and systematic uncertainties.

\begin{tabular}{|c|c|c|c|}
\hline \multirow{2}{*}{$\begin{array}{l}\text { Thermocouple } \\
\text { material }\end{array}$} & \multicolumn{3}{|c|}{ Total uncertainty } \\
\hline & $4-20 \mathrm{~K}$ & $20-75 \mathrm{~K}$ & $75-280 \mathrm{~K}$ \\
\hline Type E $\ldots \ldots \ldots$ & $29.9 \mathrm{mK}$ & $10.8 \mathrm{mK}$ & $25.1 \mathrm{mK}$ \\
\hline Type $K_{\ldots} \ldots \ldots$ & 38.1 & 12.0 & 25.9 \\
\hline Type T $\ldots \ldots \ldots$ & 25.4 & 10.5 & 24.7 \\
\hline Pt versus $K \mathrm{~N}_{\ldots} \ldots$ & 112.3 & 21.7 & 27.7 \\
\hline$K P$ versus $P t_{\ldots} \ldots$ & 132.9 & 40.2 & 28.1 \\
\hline $\mathrm{Pt}$ versus $\mathrm{TN}_{-\ldots}$ & 40.1 & 12.3 & 24.8 \\
\hline $\mathrm{Pt}$ versus $\mathrm{TP} \ldots$ & 529.6 & 39.8 & 141.2 \\
\hline $\begin{array}{l}\text { Pt versus } \mathrm{Agg}_{-28} \\
\text { at } \% \mathrm{Au}\end{array}$ & 153.2 & 18.3 & 57.3 \\
\hline $\begin{array}{l}\text { Ag- } 28 \text { at } \% \mathrm{Au} \\
\text { versus } \mathrm{KN}\end{array}$ & 267.0 & 58.7 & 29.9 \\
\hline $\begin{array}{l}\mathrm{KP} \text { versus } \mathrm{Ag}-28 \\
\text { at } \% \mathrm{Au}\end{array}$ & 89.1 & 19.9 & 27.2 \\
\hline$\frac{\mathrm{Ag} \cdot 28 \text { at } \% \mathrm{Au}}{\text { versus } \mathrm{TN}}$ & 52.5 & 16.2 & 25.4 \\
\hline $\begin{array}{l}\mathrm{TP} \text { versus } \mathrm{Ag}-28 \\
\text { at\% } \mathrm{Au}\end{array}$ & 597.9 & 112.7 & 61.2 \\
\hline
\end{tabular}

our measurement of thermocouple voltages: (1) potentiometer uncertainty, (2) uncertainty in the standard reference cells used with the potentiometer, and (3) adjustment of the actual reference temperatures to a fixed value at $4.0,20.0$, and $75.0 \mathrm{~K}$, using calculated values of $d E / d T$ for each of the thermocouple combinations. Estimates of these systematic errors are given in table 10.

The total uncertainties in the thermoelectric voltages expressed in millikelvin, are given in table 11 . The values in the table are obtained by taking the square root of the sum of the squares of the corresponding values in tables $7,8,9$ and 10 . The voltage uncertainties are converted to temperature uncertainties by dividing them by the Seebeck coefficient, $d E / d T$, appropriate for each thermocouple combination in each temperature range.

\section{Standard Tables and Functions}

Units for the thermocouple tables and functions are based on the "NBS as-maintained volt" [20]; the International Practical Temperature Scale, IPTS-68 $[21,22,23]$ for temperature above $20 \mathrm{~K}$; and the NBS acoustical scale, P 2-20 (1965) [24, 25] for temperatures between 4 and $20 \mathrm{~K}$. The tabular values of thermovoltages for Types $\mathrm{E}, \mathrm{K}$, and $\mathrm{T}$ are slightly different from those reported informally by us earlier
$[26,27]$. The earlier values were based on a preliminary IPTS-68 scale; the preliminary and final IPTS-68 scales differed slightly.

The thermovoltages for the other thermocouple combinations ( $\mathrm{Pt}$ and Ag-28 at\% Au versus KP, KN. TP, TN) are also different from those reported earlier; they have been adjusted in two ways. The temperature scale modification discussed above was required to 


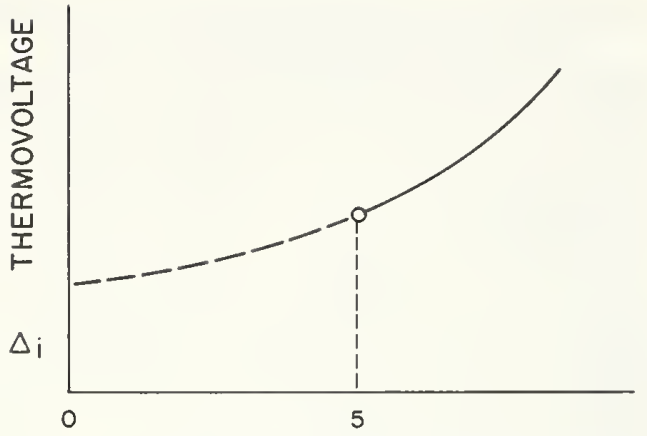

TEMPERATURE, Kelvin

Figure 11. Illustration of the nonzero thermoelectric voltage at $\mathrm{T}=0 \mathrm{~K}$ which results when experimental data are extrapolated from $5 \mathrm{~K}$ to $0 \mathrm{~K}$.

base these values on the final IPTS-68 and the NBS P 2-20 (1965) scales. The second modification was required to establish internal consistency between the tables referenced to platinum and $\mathrm{Ag}-28$ at $\% \mathrm{Au}$ and those tables based on the $\mathrm{E}, \mathrm{K}$, and $\mathrm{T}$ combinations. For example,

$$
\text { Type } E=E P-E N=(E P-\mathrm{Pt})+(\mathrm{Pt}-E N) \text {. }
$$

The algebraic combination of the values for $(\mathrm{EP}-\mathrm{Pt})$ and $(\mathrm{Pt}-\mathrm{EN})$ must yield $(\mathrm{EP}-\mathrm{EN})$. The reason for the earlier inconsistency in the absolute numbers (there was no inconsistency if temperature differences were used) was that our data were extrapolated to $0 \mathrm{~K}$ from about $5 \mathrm{~K}$. Each resulting table was then shifted by a constant $\Delta_{i}$ (see figure 11) so that $E=0 \mu \mathrm{V}$ at $T=0 \mathrm{~K}$. Since each table was shifted by a constant, $\Delta_{i}$, the sensitivity or slope was not affected. The difference in thermal voltage between any two temperatures has not been changed. It must be emphasized that the adjustments made for these reasons do not devalue the data significantly; the need for the shifts was created by requiring that $E=0 \mu \mathrm{V}$ at $T=0 \mathrm{~K}$ when the extrapolation from the lowest data point would not otherwise pass through $E=0 \mu \mathrm{V}$ at $T=0 \mathrm{~K}$.

The method used to insure additive consistency among all of the tables was to solve three simultaneous equations for the materials referenced to platinum. Equations for those materials are as follows:

(1) Type $E=\left(E P-\mathrm{Pt}+\Delta_{E P}\right)+\left(\mathrm{Pt}-\mathrm{EN}+\Delta_{E N}\right)$,

(2) Type $K=\left(K P-\mathrm{Pt}+\Delta_{K P}\right)+\left(\mathrm{Pt}-K N+\Delta_{K N}\right)$,

and

(3) Type $T=\left(\mathrm{Pt}-T N+\Delta_{T N}\right)-\left(\mathrm{Pt}-T P+\Delta_{T P}\right)$.

Note that $E P=K P$ and that $T N=E N$ so that $\Delta_{E P}=\Delta_{K P}$ and $\Delta_{T N}=\Delta_{E N}$. Let $\Delta_{E N}=0$ arbitrarily, then

(1) Type $E=\left(E P-\mathrm{Pt}+\Delta_{E P}\right)+(\mathrm{Pt}-E N)$,

(2) Type $K=\left(E P-\mathrm{Pt}+\Delta_{E P}\right)+\left(\mathrm{Pt}-K N+\Delta_{K N}\right)$, and

(3) Type $T=(\mathrm{Pt}-E N)-\left(\mathrm{Pt}-T P+\Delta_{T P}\right)$.

The required shifts are then determined by eqs. (4), (5), and (6) below.

(4) $\Delta_{E P}=$ Type $E-(E P-\mathrm{Pt})-(\mathrm{Pt}-E N)$,

(5) $\Delta_{K N}=$ Type $K-$ Type $E-(\mathrm{Pt}-K N)+(\mathrm{Pt}-E N)$,

and

(6) $\Delta_{T P}=(\mathrm{Pt}-E N)-(\mathrm{Pt}-T P)-$ Type $T$.

The tables referenced to Ag-28 at\% Au are calculated by eqs. (7) through (10).

(7) $\mathrm{EP}-\underline{\mathrm{Ag}}-28 \mathrm{at} \% \mathrm{Au}$

$$
=(\mathrm{Pt}-\underline{\mathrm{Ag}} \cdot 28 \mathrm{at} \% \mathrm{Au})+(E P-\mathrm{Pt}),
$$

(8) Ag-28 at\% Au $-K N$

$$
=(\mathrm{Pt}-K N)-(\mathrm{Pt}-\underline{\mathrm{Ag}}-28 \mathrm{at} \% \mathrm{Au}),
$$

(9) $\mathrm{Ag}-28 \mathrm{at} \% \mathrm{Au}-\mathrm{TN}$

$$
=(\mathrm{Pt}-T N)-(\mathrm{Pt}-\underline{A g}-28 \mathrm{at} \% \mathrm{Au}),
$$

and

(10) $T P-A g-28$ at $\% \mathrm{Au}$

$$
=(\mathrm{Pt}-\underline{\mathrm{Ag}}-28 \mathrm{at} \% \mathrm{Au})-(\mathrm{Pt}-T P) .
$$

The platinum-referenced tables used in these equations include the adjustments discussed previously.

Tabular data for thermocouple types $\mathrm{E}, \mathrm{K}$, and $\mathrm{T}$ are presented in three different forms. The first form, given in tables 12,13 , and 14, is the full-precision representations of $E(T), S(T)$, and $d S(T)$. The second and third forms of the same data are reduced precision tables for both $E(T)$ (tables 15, 16, and 17) and $T(E)$ (tables 18, 19, and 20). Tables 12 through 17 are referenced to $0 \mathrm{~K}$ while tables 18 through 20 are referenced to $0^{\circ} \mathrm{C}(273.15 \mathrm{~K})$. The reduced precision formats are especially useful for field applications.

The remaining thermocouple combinations consist of platinum and Ag.28 at\% Au versus the materials in thermocouple types $\mathrm{E}, \mathrm{K}$, and $\mathrm{T}$. These tabular data are presented in tables 21 through 29 as $E(T), S(T)$, and $d S(T)$ in full precision. Other tabular formats for these data are not given.

Graphic representation of $E, d E / d T \equiv S$ and $d^{2} E / d T^{2} \equiv d S / d T$ versus $T$ are given in figures 12 through 14 for thermocouple types $\mathrm{E}, \mathrm{K}$, and $\mathrm{T}$. Graphs of $\mathrm{E}$ and $\mathrm{S}$ versus $\mathrm{T}$ are given in figures 15 through 18 for the remaining thermocouple combinations. 
Modern methods of data analysis require that functional representations of thermocouple data also bc available. As mentioned previously, the full precision tables presented in this report were generated with orthonormal polynomials and coefficients. Our primary reason for using this approach, rather than the more common power series, was that we could select the optimum order for the fit and then examine lower and higher orders without having to redetermine new coefficients. In the final analysis, this functional approach presents the user with an often needed alternative not available when power series alone are used.

Since each fit in the orthonormal polynomial scheme represents a best fit for that order, the user can determine his own accuracy requirements and choose the lowest order fit that fills these particular needs. Computer economy benefits greatly from this freedom. In situations where all of the precision inherent in the experimental data is required, a power series using the highest order of fit may be used, using the recombined coefficients from the orthogonal expansion.

The thermal voltages given in tables 12 through 14 and 21 through 29 are given by

$$
E(T)=A_{o}+\sum_{n=1}^{L} A_{n} F_{n}(T)
$$

where the orthogonal polynomials $F_{n}(T)$ are given by

$$
F_{n}(T)=\sum_{j=1}^{n} C_{n j} T^{j}
$$

The $F_{n}(T)$ (up to $n=14$ ) for our data are given in table 30 to 12 significant figures. For computer economy and round-off considerations, the table is given in the product-factored form. The orthogonal polynomial coefficients, $A_{n}$, for each of the thermocouple combinations are given in tables 31 and 32 . The numbers are given with a sufficient number of significant digits so that no precision is lost in the final calculation. Since many computers cannot handle 12 significant figures in single precision, double pre- cision constants and software are usually required if the computed valucs are to retain all of the precision inherent in the experimental data. If the full array of functions and constants $\left(L_{\mathrm{MAX}}\right)_{i}$ are used with a double precision program, the resultant precision of the data fits are those given in tables 7 and 8 .

The thermocouple calibration data given in tables ] 2 through 14 and 21 through 29 werc computed using 26 digits (84 binary bits) and the highest order fit $\left(L_{i}\right)$ for each thermocouple combination, as given in tables 31 and 32 .

However, the functional representation can be simplified at the cost of increasing the standard deviation of the fit. One simplifying step is to reduce the order of the fit. This may be done without having to redetermine the constants due to the orthogonal representation, i.e., the lower order function uses the same $A_{n}$ and represents the best fit for that order. The standard deviation of the fit increases as the order is reduced, as is shown in tables 33 and 34. A second method of simplifying the computation is to reduce the number of digits carried in the calculations. Table 35 shows the limits of error to be expected when using decreasing numbers of digits. When reducing either the number of coefficients used or the number of digits carried, one must consider both the errors found in tables 33 and 34 and table 35 . For example, if one wishes to generate the data for Type $T$ with a precision of $1 \mu \mathrm{V}$, table 33 shows that $L=6$. Table 35 shows that to achieve this precision 10 decimal digits (32 binary bits) should be carried.

The full precision data may be generated using the more common power series formulation:

$$
E(T)=B_{o}+\sum_{n=1}^{L} B_{n} T^{n}
$$

for each of the thermocouple combinations being reported. Tables 36 and 37 contain the $B_{n}$ needed; again, the $B_{n}$ are given with a sufficient number of digits so that no significant precision is lost. The resultant precision is the same as for the highest order orthogonal fit. 


\begin{tabular}{|c|c|c|c|c|c|c|c|c|c|c|c|}
\hline $\begin{array}{l}T \\
K\end{array}$ & $\underset{\mu V}{E}$ & $\stackrel{S}{V} / K^{S}$ & $\begin{array}{l}d S / d T \\
n V / K^{2}\end{array}$ & $\begin{array}{l}T \\
K\end{array}$ & ${ }_{\mu V}^{E}$ & $\stackrel{S}{\mu V / K}$ & $\begin{array}{l}d S / d T \\
A V / K^{2}\end{array}$ & $\begin{array}{l}T \\
K\end{array}$ & $\underset{\mu V}{E}$ & $\stackrel{S}{\mu^{V} / K}$ & $\begin{array}{l}d S / d T \\
n V / K^{2}\end{array}$ \\
\hline $\begin{array}{l}0 \\
1 \\
2 \\
3 \\
4\end{array}$ & $\begin{array}{l}0.00 \\
0.09 \\
0.76 \\
1.97 \\
3.69\end{array}$ & $\begin{array}{r}-0.203 \\
0.384 \\
0.941 \\
1.472 \\
1.978\end{array}$ & $\begin{array}{l}604.4 \\
571.8 \\
543.0 \\
517.7 \\
495.6\end{array}$ & $\begin{array}{l}60 \\
61 \\
62 \\
63 \\
64\end{array}$ & $\begin{array}{l}704.83 \\
726.61 \\
748.66 \\
770.99 \\
793.59\end{array}$ & $\begin{array}{l}21.637 \\
21.915 \\
22.192 \\
22.466 \\
22.738\end{array}$ & $\begin{array}{l}280.0 \\
277.7 \\
275.4 \\
273.1 \\
270.9\end{array}$ & $\begin{array}{l}120 \\
121 \\
122 \\
123 \\
124\end{array}$ & $\begin{array}{l}2445.13 \\
2480.84 \\
2516.75 \\
2552.86 \\
2589.17\end{array}$ & $\begin{array}{l}35.611 \\
35.811 \\
36.009 \\
36.207 \\
36.403\end{array}$ & $\begin{array}{l}199.7 \\
198.8 \\
198.0 \\
197.1 \\
196.2\end{array}$ \\
\hline $\begin{array}{l}5 \\
6 \\
7 \\
8 \\
9\end{array}$ & $\begin{array}{r}5.92 \\
8.61 \\
11.77 \\
15.38 \\
19.41\end{array}$ & $\begin{array}{l}2.464 \\
2.931 \\
3.383 \\
3.821 \\
4.248\end{array}$ & $\begin{array}{l}476 \cdot 2 \\
459 \cdot 4 \\
444 \cdot 7 \\
432 \cdot 1 \\
421 \cdot 1\end{array}$ & $\begin{array}{l}65 \\
66 \\
67 \\
68 \\
69\end{array}$ & $\begin{array}{l}816.47 \\
839.61 \\
863.02 \\
886.69 \\
910.63\end{array}$ & $\begin{array}{l}23.008 \\
23.276 \\
23.541 \\
23.805 \\
24.067\end{array}$ & $\begin{array}{l}268.8 \\
266.7 \\
264.6 \\
262.6 \\
260.7\end{array}$ & $\begin{array}{l}125 \\
126 \\
127 \\
128 \\
129\end{array}$ & $\begin{array}{l}2625.67 \\
2662.36 \\
2699.25 \\
2736.34 \\
2773.62\end{array}$ & $\begin{array}{l}36.599 \\
36.794 \\
36.988 \\
37.181 \\
37.374\end{array}$ & $\begin{array}{l}195.4 \\
194.5 \\
193.7 \\
192.9 \\
192.0\end{array}$ \\
\hline $\begin{array}{l}10 \\
11 \\
12 \\
13 \\
14\end{array}$ & $\begin{array}{l}23.87 \\
28.74 \\
34.01 \\
39.68 \\
45.74\end{array}$ & $\begin{array}{l}4.664 \\
5.072 \\
5.472 \\
5.865 \\
6.254\end{array}$ & $\begin{array}{l}411.7 \\
403.6 \\
396.7 \\
390.8 \\
385.8\end{array}$ & $\begin{array}{l}70 \\
71 \\
72 \\
73 \\
74\end{array}$ & $\begin{array}{r}934.82 \\
959.28 \\
983.99 \\
1008.96 \\
1034.18\end{array}$ & $\begin{array}{l}24.326 \\
24.584 \\
24.840 \\
25.094 \\
25.347\end{array}$ & $\begin{array}{l}258.8 \\
256.9 \\
255.1 \\
253.4 \\
251.7\end{array}$ & $\begin{array}{l}130 \\
131 \\
132 \\
133 \\
134\end{array}$ & $\begin{array}{l}2811.09 \\
2848.75 \\
2886.60 \\
2924.64 \\
2962.87\end{array}$ & $\begin{array}{l}37.565 \\
37.756 \\
37.946 \\
38.136 \\
38.324\end{array}$ & $\begin{array}{l}191.2 \\
190.4 \\
189.6 \\
188.9 \\
188.1\end{array}$ \\
\hline $\begin{array}{l}15 \\
16 \\
17 \\
18 \\
19\end{array}$ & $\begin{array}{l}52.18 \\
59.01 \\
66.22 \\
73.80 \\
81.75\end{array}$ & $\begin{array}{l}6.637 \\
7.017 \\
7.393 \\
7.766 \\
8.137\end{array}$ & $\begin{array}{l}381.5 \\
377.8 \\
374.6 \\
371.9 \\
369.5\end{array}$ & $\begin{array}{l}75 \\
76 \\
77 \\
78 \\
79\end{array}$ & $\begin{array}{l}1059.65 \\
1085.37 \\
1111.35 \\
1137.56 \\
1164.03\end{array}$ & $\begin{array}{l}25.598 \\
25.847 \\
26.095 \\
26.341 \\
26.585\end{array}$ & $\begin{array}{l}250.0 \\
248.4 \\
246.9 \\
245.4 \\
243.9\end{array}$ & $\begin{array}{l}135 \\
136 \\
137 \\
138 \\
139\end{array}$ & $\begin{array}{l}3001.29 \\
3039.89 \\
3078.69 \\
3117.66 \\
3156.83\end{array}$ & $\begin{array}{l}38.512 \\
38.699 \\
38.885 \\
39.070 \\
39.255\end{array}$ & $\begin{array}{l}187.3 \\
186.6 \\
185.9 \\
185.1 \\
184.4\end{array}$ \\
\hline $\begin{array}{l}20 \\
21 \\
22 \\
23 \\
24\end{array}$ & $\begin{array}{r}90.07 \\
98.76 \\
107.81 \\
117.23 \\
127.01\end{array}$ & $\begin{array}{l}8.505 \\
8.872 \\
9.237 \\
9.600 \\
9.961\end{array}$ & $\begin{array}{l}367.4 \\
365.6 \\
363.9 \\
362.3 \\
360.8\end{array}$ & $\begin{array}{l}80 \\
81 \\
82 \\
83 \\
84\end{array}$ & $\begin{array}{l}1190.73 \\
1217.68 \\
1244.87 \\
1272.30 \\
1299.97\end{array}$ & $\begin{array}{l}26.829 \\
27.070 \\
27.311 \\
27.550 \\
27.787\end{array}$ & $\begin{array}{l}242.4 \\
241.0 \\
239.7 \\
238.3 \\
237.0\end{array}$ & $\begin{array}{l}140 \\
141 \\
142 \\
143 \\
144\end{array}$ & $\begin{array}{l}3196.17 \\
3235.70 \\
3275.42 \\
3315.31 \\
3355.39\end{array}$ & $\begin{array}{l}39.439 \\
39.623 \\
39.805 \\
39.987 \\
40.169\end{array}$ & $\begin{array}{l}183 \cdot 7 \\
183 \cdot 0 \\
182 \cdot 3 \\
181 \cdot 6 \\
180.9\end{array}$ \\
\hline $\begin{array}{l}25 \\
26 \\
27 \\
28 \\
29\end{array}$ & $\begin{array}{l}137.15 \\
147.65 \\
158.51 \\
169.73 \\
181.30\end{array}$ & $\begin{array}{l}10 \cdot 321 \\
10.680 \\
11.037 \\
11.393 \\
11.747\end{array}$ & $\begin{array}{l}359.3 \\
357.9 \\
356.4 \\
354.9 \\
353.4\end{array}$ & $\begin{array}{l}85 \\
86 \\
87 \\
88 \\
89\end{array}$ & $\begin{array}{l}1327.88 \\
1356.02 \\
1384.40 \\
1413.01 \\
1441.85\end{array}$ & $\begin{array}{l}28.024 \\
28.259 \\
28.493 \\
28.725 \\
28.957\end{array}$ & $\begin{array}{l}235 \cdot 7 \\
234.5 \\
233 \cdot 2 \\
232.0 \\
230.9\end{array}$ & $\begin{array}{l}145 \\
146 \\
147 \\
148 \\
149\end{array}$ & $\begin{array}{l}3395.65 \\
3436.09 \\
3476.71 \\
3517.51 \\
3558.48\end{array}$ & $\begin{array}{l}40.349 \\
40.529 \\
40.708 \\
40.887 \\
41.065\end{array}$ & $\begin{array}{l}180.3 \\
179.6 \\
179.0 \\
178.3 \\
177.7\end{array}$ \\
\hline $\begin{array}{l}30 \\
31 \\
32 \\
33 \\
34\end{array}$ & $\begin{array}{l}193.22 \\
205.50 \\
218.12 \\
231.09 \\
244.41\end{array}$ & $\begin{array}{l}12.099 \\
12.450 \\
12.800 \\
13.147 \\
13.493\end{array}$ & $\begin{array}{l}351.8 \\
350.1 \\
348.4 \\
346.5 \\
344.6\end{array}$ & $\begin{array}{l}90 \\
91 \\
92 \\
93 \\
94\end{array}$ & $\begin{array}{l}1470.92 \\
1500.22 \\
1529.75 \\
1559.51 \\
1589.49\end{array}$ & $\begin{array}{l}29.187 \\
29.416 \\
29.644 \\
29.871 \\
30.097\end{array}$ & $\begin{array}{l}229.7 \\
228.6 \\
227.4 \\
226.3 \\
225 \cdot 2\end{array}$ & $\begin{array}{l}150 \\
151 \\
152 \\
153 \\
154\end{array}$ & $\begin{array}{l}3599.64 \\
3640.97 \\
3682.47 \\
3724.16 \\
3766.02\end{array}$ & $\begin{array}{l}41 \cdot 242 \\
41.419 \\
41.595 \\
41.771 \\
41.946\end{array}$ & $\begin{array}{l}177 \cdot 0 \\
176.4 \\
175 \cdot 8 \\
175.2 \\
174.6\end{array}$ \\
\hline $\begin{array}{l}35 \\
36 \\
37 \\
38 \\
39\end{array}$ & $\begin{array}{l}258.08 \\
272.09 \\
286.43 \\
301.12 \\
316.14\end{array}$ & $\begin{array}{l}13.836 \\
14.178 \\
14.517 \\
14.855 \\
15.190\end{array}$ & $\begin{array}{l}342.7 \\
340.6 \\
338.4 \\
336.2 \\
333.9\end{array}$ & $\begin{array}{l}95 \\
96 \\
97 \\
98 \\
99\end{array}$ & $\begin{array}{l}1619.70 \\
1650.13 \\
1680.79 \\
1711.67 \\
1742.77\end{array}$ & $\begin{array}{l}30.321 \\
30.545 \\
30.768 \\
30.989 \\
31.210\end{array}$ & $\begin{array}{l}224 \cdot 1 \\
223 \cdot 1 \\
222 \cdot 0 \\
221 \cdot 0 \\
219 \cdot 9\end{array}$ & $\begin{array}{l}155 \\
156 \\
157 \\
158 \\
159\end{array}$ & $\begin{array}{l}3808.05 \\
3850.26 \\
3892.64 \\
3935.19 \\
3977.91\end{array}$ & $\begin{array}{l}42.120 \\
42.293 \\
42.466 \\
42.639 \\
42.811\end{array}$ & $\begin{array}{l}173.9 \\
173 \cdot 3 \\
172 \cdot 7 \\
172.1 \\
171.5\end{array}$ \\
\hline $\begin{array}{l}40 \\
41 \\
42 \\
43 \\
44\end{array}$ & $\begin{array}{l}331 \cdot 50 \\
347 \cdot 19 \\
363 \cdot 20 \\
379 \cdot 55 \\
396.21\end{array}$ & $\begin{array}{l}15.523 \\
15.853 \\
16.181 \\
16.506 \\
16.829\end{array}$ & $\begin{array}{l}331 \cdot 5 \\
329 \cdot 1 \\
326 \cdot 6 \\
324 \cdot 1 \\
321.5\end{array}$ & $\begin{array}{l}100 \\
101 \\
102 \\
103 \\
104\end{array}$ & $\begin{array}{l}1774.09 \\
1805.63 \\
1837.38 \\
1869.36 \\
1901.54\end{array}$ & $\begin{array}{l}31.429 \\
31.647 \\
31.865 \\
32.081 \\
32.297\end{array}$ & $\begin{array}{l}218.9 \\
217.9 \\
216.9 \\
215.9 \\
214.9\end{array}$ & $\begin{array}{l}160 \\
161 \\
162 \\
163 \\
164\end{array}$ & $\begin{array}{l}4020.81 \\
4063.88 \\
4107.11 \\
4150.52 \\
4194.10\end{array}$ & $\begin{array}{l}42.982 \\
43.153 \\
43.323 \\
43.492 \\
43.661\end{array}$ & $\begin{array}{l}170.9 \\
170.3 \\
169.7 \\
169.1 \\
168.5\end{array}$ \\
\hline $\begin{array}{l}45 \\
46 \\
47 \\
48 \\
49\end{array}$ & $\begin{array}{l}413 \cdot 20 \\
430 \cdot 51 \\
448 \cdot 14 \\
466 \cdot 07 \\
484.32\end{array}$ & $\begin{array}{l}17.149 \\
17.467 \\
17.782 \\
18.094 \\
18.404\end{array}$ & $\begin{array}{l}318.9 \\
316 \cdot 3 \\
313 \cdot 6 \\
311.0 \\
308.3\end{array}$ & $\begin{array}{l}105 \\
106 \\
107 \\
108 \\
109\end{array}$ & $\begin{array}{l}1933.95 \\
1966.57 \\
1999.40 \\
2032.44 \\
2065.69\end{array}$ & $\begin{array}{l}32.511 \\
32.724 \\
32.937 \\
33.148 \\
33.359\end{array}$ & $\begin{array}{l}213.9 \\
212.9 \\
211.9 \\
210.9 \\
210.0\end{array}$ & $\begin{array}{l}165 \\
166 \\
167 \\
168 \\
169\end{array}$ & $\begin{array}{l}4237.84 \\
4281.76 \\
4325.84 \\
4370.08 \\
4414.50\end{array}$ & $\begin{array}{l}43.829 \\
43.997 \\
44.164 \\
44.330 \\
44.496\end{array}$ & $\begin{array}{l}167 \cdot 9 \\
167 \cdot 3 \\
166 \cdot 7 \\
166 \cdot 1 \\
165 \cdot 5\end{array}$ \\
\hline $\begin{array}{l}50 \\
51 \\
52 \\
53 \\
54\end{array}$ & $\begin{array}{l}502 \cdot 88 \\
521 \cdot 74 \\
540 \cdot 91 \\
560.38 \\
580 \cdot 14\end{array}$ & $\begin{array}{l}18.711 \\
19.015 \\
19.317 \\
19.616 \\
19.912\end{array}$ & $\begin{array}{l}305 \cdot 6 \\
303.0 \\
300 \cdot 3 \\
297 \cdot 7 \\
295 \cdot 1\end{array}$ & $\begin{array}{l}110 \\
111 \\
112 \\
113 \\
114\end{array}$ & $\begin{array}{l}2099.16 \\
2132.83 \\
2166.71 \\
2200.80 \\
2235.09\end{array}$ & $\begin{array}{l}33.568 \\
33.777 \\
33.984 \\
34.191 \\
34.397\end{array}$ & $\begin{array}{l}209.0 \\
208.1 \\
207 \cdot 1 \\
206.2 \\
205.2\end{array}$ & $\begin{array}{l}170 \\
171 \\
172 \\
173 \\
174\end{array}$ & $\begin{array}{l}4459.07 \\
4503.82 \\
4548.73 \\
4593.80 \\
4639.03\end{array}$ & $\begin{array}{l}44 \cdot 661 \\
44.826 \\
44.990 \\
45.153 \\
45.316\end{array}$ & $\begin{array}{l}164 \cdot 9 \\
164 \cdot 3 \\
163 \cdot 7 \\
163 \cdot 1 \\
162.5\end{array}$ \\
\hline $\begin{array}{l}55 \\
56 \\
57 \\
58 \\
59\end{array}$ & $\begin{array}{l}600 \cdot 20 \\
620 \cdot 55 \\
641 \cdot 19 \\
662 \cdot 12 \\
683 \cdot 33\end{array}$ & $\begin{array}{l}20 \cdot 206 \\
20.497 \\
20 \cdot 786 \\
21.072 \\
21.355\end{array}$ & $\begin{array}{l}292.5 \\
289.9 \\
287.4 \\
284.9 \\
282.5\end{array}$ & $\begin{array}{l}115 \\
116 \\
117 \\
118 \\
119\end{array}$ & $\begin{array}{l}2269.59 \\
2304.29 \\
2339 \cdot 20 \\
2374 \cdot 31 \\
2409.62\end{array}$ & $\begin{array}{l}34.601 \\
34.805 \\
35.008 \\
35.210 \\
35.411\end{array}$ & $\begin{array}{l}204 \cdot 3 \\
203 \cdot 4 \\
202 \cdot 4 \\
201 \cdot 5 \\
200.6\end{array}$ & $\begin{array}{l}175 \\
176 \\
177 \\
178 \\
179\end{array}$ & $\begin{array}{l}4684.43 \\
4729.99 \\
4775.71 \\
4821.59 \\
4867.63\end{array}$ & $\begin{array}{l}45 \cdot 478 \\
45 \cdot 640 \\
45.800 \\
45.961 \\
46.120\end{array}$ & $\begin{array}{l}161 \cdot 8 \\
161 \cdot 2 \\
160 \cdot 6 \\
160 \cdot 0 \\
159.4\end{array}$ \\
\hline 60 & 704.83 & 21.637 & 280.0 & 120 & 2445.13 & 35.611 & 199.7 & 180 & 4913.83 & 46.279 & 158.7 \\
\hline
\end{tabular}


214

215

216

217

218

219

220

221

222

223

224

232

233

234

235

236

237

238

239

240

\section{EV \\ $\mathrm{\mu V} / \mathrm{K}$}

4913.83

4960.19

5006.70

5053.38

5100.21

5147.20

$5194 \cdot 34$

5241.64

5289.09

5336.70

5384.46

5432.37

5480.43

5528.65

5577.01

5625.53

5674.19

5723.00

5771.97

5821.08

5870.33

5919.74

5969.28

6018.98

6068.82

6118.80

6168.93

6219.20

6269.61

$6320 \cdot 16$

6370.86

6421.69

6472.67

6523.79

6575.04

6626.44

6677.97

6729.64

6781.45

6833.39

6885.47

6937.69

6990.04

7042.53

$7095 \cdot 15$

7147.90

7200.79

7253.81

7306.97

7360.25

$7413 \cdot 67$

7467.22

7520.89

7574.70

$7628 \cdot 64$

$7682 \cdot 70$

7736.90

7791.22

7845.67

7900.25

7954.95

46.279

46.438

46.596

4.753

46.909

47. 065

47.221

47.375

47.529

47.683

47.835

47.988

48.139

48.290

48.440

48.590

48.739

48.888

49.036

49.183

49.330

49.476

49.622

49.767

49.911

50.055

50.198

50.341

50.483

50.625

50.766

50.907

51.047

51.186

51.325

$51 \cdot 464$

51.602

51.739

51.876

52.013

52.149

52.284

52.419

52.554

52.688

$52 \cdot 821$

52.955

53.087

53.219

53.482

53.613

53.743

53.872

54.002

54.259

54.767
dS/dT

nV/K2

158.7

$158 \cdot 1$

242

243

$156.2 \quad 244$

155.6

155.0

154.4

153.7

153.1

152.5

151.9

151.2

150.6

150.0

149.4

148.8

148.2

147.6

147.0

$146 \cdot 4$

145.9

145.3

144.7

143.6

143.0

142.5

141.9

141.4

140.9

140.3

139.8

139.3

138.3

137.8

137.3

136.8

136.3

135.8

$135 \cdot 3$

134.8

134.3

133.8

133.3

132.8

$132 \cdot 3$

131.9

130.9

130.4

129.9

129.4

129.0

$54.130 \quad 128.5$

128.0

$54.386 \quad 127.5$

$54.514 \quad 127.1$

$54.641 \quad 126.6$

$126 \cdot 1$

$T$
$K$
240
241
242
243
244
245

EV

s

AS/T

$n V / K^{2}$

7954.95

8009.78

8064.74

8119.82

8175.02

54.767

$55.018 \quad 125.7$

$55.143 \quad 124.8$

$55.268 \quad 124.3$

$\begin{array}{lll}8230.35 & 55.392 & 123.9\end{array}$

$8285.81 \quad 55.516 \quad 123.5$

$8341.38 \quad 55.639 \quad 123.1$

$\begin{array}{lll}8397.09 & 55.762 & 122.7\end{array}$

$\begin{array}{lll}8452.91 & 55.884 & 122.3\end{array}$

$8508.85 \quad 56.006 \quad 121.9$

$8564.92 \quad 56.128 \quad 121.5$

$8621.1156 .250 \quad 121.2$

$8677.42 \quad 56.371-120.8$

$\begin{array}{lll}8733.85 & 56.491 & 120.5\end{array}$

$8790.40 \quad 56.611 \quad 120.1$

$\begin{array}{lll}8847.07 & 56.731 & 119.8\end{array}$

$8903.86 \quad 56.851 \quad 119.4$

$8960.78 \quad 56.970 \quad 119.1$

$9017.81 \quad 57.089 \quad 118.7$

$9074.95 \quad 57.208 \quad 118.3$

$9132.22 \quad 57.326 \quad 117.9$

$9189.61 \quad 57.444 \quad 117.4$

$9247.11 \quad 57.561 \quad 116.9$

$9304.73 \quad 57.677 \quad 116.3$

$9362.46 \quad 57.793 \quad 115.6$

$9420.31 \quad 57.908 \quad 114.8$

$9478.28 \quad 58.023 \quad 113.9$

$9536.36 \quad 58.136 \quad 112.8$

$9594.55 \quad 58.248 \quad 111.5$

$\begin{array}{lll}9652.85 & 58.359 & 110.0\end{array}$

$9711.27 \quad 58.468 \quad 108.2$

$\begin{array}{llll}9769.79 & 58.575 & 106.2\end{array}$

$9828.42 \quad 58.680 \quad 103.7$

$9887.15 \quad 58.783 \quad 100.9$

$9945.98 \quad 58.882 \quad 97.6$

$10004.91 \quad 58.978 \quad 93.8$

$\begin{array}{lll}10063.94 & 59.069 & 89.3\end{array}$

$10123.05 \quad 59.156 \quad 84.2$

$\begin{array}{lll}10182.25 & 59.237 & 78.2\end{array}$

280

10241.52

59.312

71.4 


\begin{tabular}{|c|c|c|c|c|c|c|c|c|c|c|c|}
\hline $\begin{array}{l}T \\
K\end{array}$ & $\underset{\mu V}{E}$ & $\stackrel{S}{S}$ & $\begin{array}{l}\text { dS/dT } \\
n V / K^{2}\end{array}$ & $\begin{array}{l}T \\
K\end{array}$ & $\underset{\mu V}{E}$ & ${ }_{\mu V / K}^{S}$ & $\begin{array}{l}d S / d T \\
n V / K^{2}\end{array}$ & $\begin{array}{l}T \\
K\end{array}$ & $\underset{\mu V}{E V}$ & $\stackrel{S}{\mu V / K}$ & $\begin{array}{l}d S / d T \\
n V / K^{2}\end{array}$ \\
\hline $\begin{array}{l}0 \\
1 \\
2 \\
3 \\
4\end{array}$ & $\begin{array}{l}0.00 \\
0.32 \\
0.78 \\
1.42 \\
2 \cdot 21\end{array}$ & $\begin{array}{l}0.241 \\
0.391 \\
0.549 \\
0.714 \\
0.884\end{array}$ & $\begin{array}{l}146 \cdot 9 \\
154 \cdot 3 \\
161 \cdot 3 \\
167 \cdot 7 \\
173.7\end{array}$ & $\begin{array}{l}60 \\
61 \\
62 \\
63 \\
64\end{array}$ & $\begin{array}{l}383.56 \\
396.41 \\
409.47 \\
422.71 \\
436.15\end{array}$ & $\begin{array}{l}12.757 \\
12.954 \\
13.149 \\
13.344 \\
13.537\end{array}$ & $\begin{array}{l}197.0 \\
196.0 \\
195.0 \\
194.0 \\
193.0\end{array}$ & $\begin{array}{l}120 \\
121 \\
122 \\
123 \\
124\end{array}$ & $\begin{array}{l}1473.20 \\
1496.42 \\
1519.80 \\
1543.32 \\
1567.00\end{array}$ & $\begin{array}{l}23.144 \\
23.297 \\
23.451 \\
23.603 \\
23.755\end{array}$ & $\begin{array}{l}153.9 \\
153.4 \\
152.8 \\
152 \cdot 2 \\
151.6\end{array}$ \\
\hline $\begin{array}{l}5 \\
6 \\
7 \\
8 \\
9\end{array}$ & $\begin{array}{l}3.19 \\
4.34 \\
5.67 \\
7.20 \\
8.92\end{array}$ & $\begin{array}{l}1.061 \\
1.243 \\
1.429 \\
1.621 \\
1.816\end{array}$ & $\begin{array}{l}179 \cdot 2 \\
184.3 \\
189.0 \\
193.4 \\
197.3\end{array}$ & $\begin{array}{l}65 \\
66 \\
67 \\
68 \\
69\end{array}$ & $\begin{array}{l}449.79 \\
463.61 \\
477.63 \\
491.84 \\
506.23\end{array}$ & $\begin{array}{l}13.730 \\
13.922 \\
14.112 \\
14.302 \\
14.491\end{array}$ & $\begin{array}{l}192.1 \\
191.1 \\
190.2 \\
189 \cdot 2 \\
188.3\end{array}$ & $\begin{array}{l}125 \\
126 \\
127 \\
128 \\
129\end{array}$ & $\begin{array}{l}1590.83 \\
1614.81 \\
1638.95 \\
1663.23 \\
1687.66\end{array}$ & $\begin{array}{l}23.906 \\
24.057 \\
24.207 \\
24.357 \\
24.506\end{array}$ & $\begin{array}{l}151 \cdot 1 \\
150.5 \\
149.9 \\
149.3 \\
148.8\end{array}$ \\
\hline $\begin{array}{l}10 \\
11 \\
12 \\
13 \\
14\end{array}$ & $\begin{array}{l}10 \cdot 83 \\
12 \cdot 95 \\
15 \cdot 27 \\
17 \cdot 80 \\
20.53\end{array}$ & $\begin{array}{l}2 \cdot 015 \\
2 \cdot 218 \\
2 \cdot 424 \\
2 \cdot 632 \\
2 \cdot 843\end{array}$ & $\begin{array}{l}200 \cdot 9 \\
204 \cdot 2 \\
207 \cdot 2 \\
209 \cdot 9 \\
212 \cdot 3\end{array}$ & $\begin{array}{l}70 \\
71 \\
72 \\
73 \\
74\end{array}$ & $\begin{array}{l}520.82 \\
535.59 \\
550.55 \\
565.69 \\
581.02\end{array}$ & $\begin{array}{l}14.678 \\
14.865 \\
15.051 \\
15.237 \\
15.421\end{array}$ & $\begin{array}{l}187.4 \\
186.5 \\
185.6 \\
184.8 \\
183.9\end{array}$ & $\begin{array}{l}130 \\
131 \\
132 \\
133 \\
134\end{array}$ & $\begin{array}{l}1712.24 \\
1736.97 \\
1761.84 \\
1786.87 \\
1812.04\end{array}$ & $\begin{array}{l}24.654 \\
24.802 \\
24.950 \\
25.096 \\
25.243\end{array}$ & $\begin{array}{l}148.2 \\
147 \cdot 6 \\
147 \cdot 0 \\
146.4 \\
145.9\end{array}$ \\
\hline $\begin{array}{l}20 \\
21 \\
22 \\
23 \\
24\end{array}$ & $\begin{array}{l}41 \cdot 48 \\
45.75 \\
50.23 \\
54.94 \\
59.87\end{array}$ & $\begin{array}{l}4.150 \\
4.372 \\
4.595 \\
4.819 \\
5.043\end{array}$ & $\begin{array}{l}221.9 \\
222.8 \\
223.5 \\
224.0 \\
224.4\end{array}$ & $\begin{array}{l}80 \\
81 \\
82 \\
83 \\
84\end{array}$ & $\begin{array}{l}676 \cdot 83 \\
693 \cdot 43 \\
710 \cdot 20 \\
727 \cdot 16 \\
744 \cdot 29\end{array}$ & $\begin{array}{l}16.510 \\
16.688 \\
16.866 \\
17.043 \\
17.220\end{array}$ & $\begin{array}{l}179 \cdot 1 \\
178 \cdot 3 \\
177 \cdot 5 \\
176 \cdot 8 \\
176.1\end{array}$ & $\begin{array}{l}140 \\
141 \\
142 \\
143 \\
144\end{array}$ & $\begin{array}{l}1966.10 \\
1992.28 \\
2018.60 \\
2045.06 \\
2071.66\end{array}$ & $\begin{array}{l}26.107 \\
26.249 \\
26.391 \\
26.532 \\
26.672\end{array}$ & $\begin{array}{l}142 \cdot 3 \\
141 \cdot 7 \\
141.1 \\
140.6 \\
140 \cdot 0\end{array}$ \\
\hline $\begin{array}{l}25 \\
26 \\
27 \\
28 \\
29\end{array}$ & $\begin{array}{l}65.02 \\
70.40 \\
76.01 \\
81.84 \\
87.89\end{array}$ & $\begin{array}{l}5.268 \\
5.493 \\
5.718 \\
5.942 \\
6.167\end{array}$ & $\begin{array}{l}224 \cdot 7 \\
224 \cdot 9 \\
224 \cdot 9 \\
224 \cdot 8 \\
224 \cdot 6\end{array}$ & $\begin{array}{l}85 \\
86 \\
87 \\
88 \\
89\end{array}$ & $\begin{array}{l}761.60 \\
779.08 \\
796.74 \\
814.57 \\
832.58\end{array}$ & $\begin{array}{l}17.396 \\
17.571 \\
17.745 \\
17.918 \\
18.091\end{array}$ & $\begin{array}{l}175 \cdot 3 \\
174 \cdot 6 \\
173 \cdot 9 \\
173 \cdot 2 \\
172 \cdot 6\end{array}$ & $\begin{array}{l}145 \\
146 \\
147 \\
148 \\
149\end{array}$ & $\begin{array}{l}2098 \cdot 40 \\
2125.28 \\
2152.30 \\
2179 \cdot 46 \\
2206.75\end{array}$ & $\begin{array}{l}26.811 \\
26.950 \\
27.089 \\
27.227 \\
27.364\end{array}$ & $\begin{array}{l}139.4 \\
138.8 \\
138.2 \\
137.6 \\
137.0\end{array}$ \\
\hline $\begin{array}{l}30 \\
31 \\
32 \\
33 \\
34\end{array}$ & $\begin{array}{r}94 \cdot 17 \\
100 \cdot 68 \\
107 \cdot 40 \\
114 \cdot 36 \\
121.53\end{array}$ & $\begin{array}{l}6.392 \\
6.616 \\
6.840 \\
7.063 \\
7.285\end{array}$ & $\begin{array}{l}224 \cdot 3 \\
224 \cdot 0 \\
223 \cdot 5 \\
223.0 \\
222.4\end{array}$ & $\begin{array}{l}90 \\
91 \\
92 \\
93 \\
94\end{array}$ & $\begin{array}{l}850 \cdot 75 \\
869.10 \\
887.62 \\
906.31 \\
925.18\end{array}$ & $\begin{array}{l}18.264 \\
18.435 \\
18.606 \\
18.776 \\
18.946\end{array}$ & $\begin{array}{l}171.9 \\
171.2 \\
170.6 \\
169.9 \\
169.3\end{array}$ & $\begin{array}{l}150 \\
151 \\
152 \\
153 \\
154\end{array}$ & $\begin{array}{l}2234 \cdot 19 \\
2261.76 \\
2289.46 \\
2317 \cdot 30 \\
2345.27\end{array}$ & $\begin{array}{l}27.501 \\
27.637 \\
27.772 \\
27.907 \\
28.041\end{array}$ & $\begin{array}{l}136.4 \\
135.7 \\
135 \cdot 1 \\
134.5 \\
133.9\end{array}$ \\
\hline $\begin{array}{l}35 \\
36 \\
37 \\
38 \\
39\end{array}$ & $\begin{array}{l}128 \cdot 93 \\
136 \cdot 54 \\
146 \cdot 38 \\
152 \cdot 44 \\
160 \cdot 72\end{array}$ & $\begin{array}{l}7.508 \\
7.729 \\
7.950 \\
8.169 \\
8.388\end{array}$ & $\begin{array}{l}221 \cdot 7 \\
221 \cdot 0 \\
220 \cdot 3 \\
219 \cdot 4 \\
218 \cdot 6\end{array}$ & $\begin{array}{l}95 \\
96 \\
97 \\
98 \\
99\end{array}$ & $\begin{array}{r}944.21 \\
963 \cdot 40 \\
982 \cdot 77 \\
1002 \cdot 31 \\
1022.01\end{array}$ & $\begin{array}{l}19.115 \\
19.283 \\
19.451 \\
19.618 \\
19.784\end{array}$ & $\begin{array}{l}168 \cdot 6 \\
168.0 \\
167.4 \\
166.8 \\
166.2\end{array}$ & $\begin{array}{l}155 \\
156 \\
157 \\
158 \\
159\end{array}$ & $\begin{array}{l}2373 \cdot 38 \\
2401.62 \\
2430.00 \\
2458.50 \\
2487.14\end{array}$ & $\begin{array}{l}28 \cdot 175 \\
28.308 \\
28.440 \\
28.572 \\
28.703\end{array}$ & $\begin{array}{l}133 \cdot 3 \\
132 \cdot 7 \\
132 \cdot 1 \\
131 \cdot 5 \\
130.9\end{array}$ \\
\hline $\begin{array}{l}40 \\
41 \\
42 \\
43 \\
44\end{array}$ & $\begin{array}{l}169.22 \\
177.94 \\
186 \cdot 87 \\
196 \cdot 02 \\
205 \cdot 38\end{array}$ & $\begin{array}{l}8.607 \\
8.824 \\
9.040 \\
9.256 \\
9.470\end{array}$ & $\begin{array}{l}217 \cdot 7 \\
216 \cdot 8 \\
215 \cdot 8 \\
214 \cdot 9 \\
213 \cdot 9\end{array}$ & $\begin{array}{l}100 \\
101 \\
102 \\
103 \\
104\end{array}$ & $\begin{array}{l}1041.87 \\
1061.91 \\
1082 \cdot 11 \\
1102.47 \\
1122.99\end{array}$ & $\begin{array}{l}19.950 \\
20.115 \\
20.280 \\
20.444 \\
20.608\end{array}$ & $\begin{array}{l}165.5 \\
164 \cdot 9 \\
164 \cdot 3 \\
163 \cdot 7 \\
163.2\end{array}$ & $\begin{array}{l}160 \\
161 \\
162 \\
163 \\
164\end{array}$ & $\begin{array}{l}2515.91 \\
2544.81 \\
2573.84 \\
2603.00 \\
2632.28\end{array}$ & $\begin{array}{l}28.834 \\
28.964 \\
29.093 \\
29.222 \\
29.350\end{array}$ & $\begin{array}{l}130 \cdot 3 \\
129 \cdot 7 \\
129 \cdot 0 \\
128 \cdot 4 \\
127.8\end{array}$ \\
\hline $\begin{array}{l}45 \\
46 \\
47 \\
48 \\
49\end{array}$ & $\begin{array}{l}214 \cdot 95 \\
224 \cdot 74 \\
234 \cdot 75 \\
244 \cdot 96 \\
255 \cdot 38\end{array}$ & $\begin{array}{r}9.683 \\
9.896 \\
10.107 \\
10.317 \\
10.526\end{array}$ & $\begin{array}{l}212 \cdot 9 \\
211 \cdot 8 \\
210 \cdot 8 \\
209 \cdot 7 \\
208 \cdot 7\end{array}$ & $\begin{array}{l}105 \\
106 \\
107 \\
108 \\
109\end{array}$ & $\begin{array}{l}1143.68 \\
1164.53 \\
1185.55 \\
1206.72 \\
1228.06\end{array}$ & $\begin{array}{l}20.770 \\
20.933 \\
21.094 \\
21.255 \\
21.416\end{array}$ & $\begin{array}{l}162 \cdot 6 \\
162.0 \\
161.4 \\
160.8 \\
160.2\end{array}$ & $\begin{array}{l}165 \\
166 \\
167 \\
168 \\
169\end{array}$ & $\begin{array}{l}2661.70 \\
2691 \cdot 24 \\
2720.90 \\
2750.70 \\
2780.62\end{array}$ & $\begin{array}{l}29 \cdot 478 \\
29 \cdot 604 \\
29 \cdot 731 \\
29.856 \\
29.981\end{array}$ & $\begin{array}{l}127 \cdot 2 \\
126 \cdot 6 \\
126 \cdot 0 \\
125 \cdot 3 \\
124 \cdot 7\end{array}$ \\
\hline $\begin{array}{l}50 \\
51 \\
52 \\
53 \\
54\end{array}$ & $\begin{array}{l}266.01 \\
276.85 \\
287.89 \\
299 \cdot 14 \\
310 \cdot 60\end{array}$ & $\begin{array}{l}10.735 \\
10.942 \\
11.148 \\
11.353 \\
11.556\end{array}$ & $\begin{array}{l}207 \cdot 6 \\
206 \cdot 5 \\
205 \cdot 5 \\
204 \cdot 4 \\
203 \cdot 3\end{array}$ & $\begin{array}{l}110 \\
111 \\
112 \\
113 \\
114\end{array}$ & $\begin{array}{l}1249.55 \\
1271.21 \\
1293.02 \\
1315.00 \\
1337.13\end{array}$ & $\begin{array}{l}21.576 \\
21.735 \\
21.894 \\
22.052 \\
22.210\end{array}$ & $\begin{array}{l}159.7 \\
159 \cdot 1 \\
158.5 \\
157.9 \\
157.4\end{array}$ & $\begin{array}{l}170 \\
171 \\
172 \\
173 \\
174\end{array}$ & $\begin{array}{l}2810.66 \\
2840.83 \\
2871.12 \\
2901.53 \\
2932.07\end{array}$ & $\begin{array}{l}30.106 \\
30.230 \\
30.353 \\
30.475 \\
30.597\end{array}$ & $\begin{array}{l}124 \cdot 1 \\
123 \cdot 5 \\
122 \cdot 9 \\
122 \cdot 2 \\
121 \cdot 6\end{array}$ \\
\hline $\begin{array}{l}55 \\
56 \\
57 \\
58 \\
59\end{array}$ & $\begin{array}{l}322 \cdot 26 \\
334 \cdot 12 \\
346 \cdot 18 \\
358 \cdot 44 \\
370 \cdot 90\end{array}$ & $\begin{array}{l}11.759 \\
11.961 \\
12.162 \\
12.361 \\
12.560\end{array}$ & $\begin{array}{l}202 \cdot 3 \\
201 \cdot 2 \\
200 \cdot 1 \\
199 \cdot 1 \\
198 \cdot 1\end{array}$ & $\begin{array}{l}115 \\
116 \\
117 \\
118 \\
119\end{array}$ & $\begin{array}{l}1359.42 \\
1381.86 \\
1404 \cdot 46 \\
1427 \cdot 22 \\
1450 \cdot 13\end{array}$ & $\begin{array}{l}22.367 \\
22.524 \\
22.679 \\
22.835 \\
22.990\end{array}$ & $\begin{array}{l}156.8 \\
156 \cdot 2 \\
155.6 \\
155 \cdot 1 \\
154.5\end{array}$ & $\begin{array}{l}175 \\
176 \\
177 \\
178 \\
179\end{array}$ & $\begin{array}{l}2962.73 \\
2993.51 \\
3024.41 \\
3055.42 \\
3086.56\end{array}$ & $\begin{array}{l}30.718 \\
30.839 \\
30.959 \\
31.079 \\
31.197\end{array}$ & $\begin{array}{l}121 \cdot 0 \\
120 \cdot 4 \\
119 \cdot 7 \\
119 \cdot 1 \\
118 \cdot 5\end{array}$ \\
\hline 60 & 383.56 & 12.757 & 197.0 & 120 & 1473.20 & 23.144 & 153.9 & 180 & 3117.82 & $31 \cdot 316$ & $117 \cdot 9$ \\
\hline
\end{tabular}




\begin{tabular}{|c|c|c|c|c|c|c|c|c|c|c|}
\hline $\begin{array}{l}T \\
K\end{array}$ & $E_{\mu V}$ & $\stackrel{S}{V} / K^{S}$ & $\begin{array}{l}\mathrm{dS} / \mathrm{dT} \\
\mathrm{nV} / \mathrm{K}^{2}\end{array}$ & $\begin{array}{l}T \\
K\end{array}$ & $\underset{\mu V}{E}$ & $\stackrel{S}{V} / K^{S}$ & $\begin{array}{l}d S / d T \\
n V / K^{2}\end{array}$ & $\begin{array}{l}T \\
K\end{array}$ & $\underset{\mu V}{E}$ & $\stackrel{s}{\mu \forall / k}$ \\
\hline $\begin{array}{l}180 \\
181 \\
182 \\
183 \\
184\end{array}$ & $\begin{array}{l}3117.82 \\
3149.19 \\
3180.68 \\
3212.29 \\
3244.02\end{array}$ & $\begin{array}{l}31.316 \\
31.433 \\
31.550 \\
31.666 \\
31.782\end{array}$ & $\begin{array}{l}117 \cdot 9 \\
117 \cdot 2 \\
116 \cdot 6 \\
116 \cdot 0 \\
115 \cdot 3\end{array}$ & $\begin{array}{l}240 \\
241 \\
242 \\
243 \\
244\end{array}$ & $\begin{array}{l}5185.83 \\
5223.10 \\
5260.44 \\
5297.87 \\
5335.37\end{array}$ & $\begin{array}{l}37.228 \\
37.307 \\
37.385 \\
37.462 \\
37.539\end{array}$ & $\begin{array}{l}79.0 \\
78.4 \\
77.7 \\
77.1 \\
76.4\end{array}$ & & & \\
\hline $\begin{array}{l}185 \\
186 \\
187 \\
188 \\
189\end{array}$ & $\begin{array}{l}3275.86 \\
3307.81 \\
3339.88 \\
3372.06 \\
3404.36\end{array}$ & $\begin{array}{l}31.897 \\
32.011 \\
32.125 \\
32.238 \\
32.351\end{array}$ & $\begin{array}{l}114 \cdot 7 \\
114 \cdot 1 \\
113.4 \\
112 \cdot 8 \\
112.2\end{array}$ & $\begin{array}{l}245 \\
246 \\
247 \\
248 \\
249\end{array}$ & $\begin{array}{l}5372 \cdot 94 \\
5410 \cdot 60 \\
5448.32 \\
5486.13 \\
5524.00\end{array}$ & $\begin{array}{l}37.615 \\
37.691 \\
37.765 \\
37.840 \\
37.913\end{array}$ & $\begin{array}{l}75 \cdot 8 \\
75.1 \\
74.5 \\
73.8 \\
73.2\end{array}$ & & & \\
\hline $\begin{array}{l}190 \\
191 \\
192 \\
193 \\
194\end{array}$ & $\begin{array}{l}3436 \cdot 76 \\
3469 \cdot 28 \\
3501.91 \\
3534.65 \\
3567.50\end{array}$ & $\begin{array}{l}32.463 \\
32.574 \\
32.684 \\
32.794 \\
32.904\end{array}$ & $\begin{array}{l}111 \cdot 5 \\
110 \cdot 9 \\
110 \cdot 3 \\
109 \cdot 6 \\
109 \cdot 0\end{array}$ & $\begin{array}{l}250 \\
251 \\
252 \\
253 \\
254\end{array}$ & $\begin{array}{l}5561.95 \\
5599.98 \\
5638.07 \\
5676.23 \\
5714.47\end{array}$ & $\begin{array}{l}37.986 \\
38.058 \\
38.130 \\
38.201 \\
38.271\end{array}$ & $\begin{array}{l}72.5 \\
71.9 \\
71.2 \\
70.6 \\
69.9\end{array}$ & & & \\
\hline $\begin{array}{l}195 \\
196 \\
197 \\
198 \\
199\end{array}$ & $\begin{array}{l}3600 \cdot 46 \\
3633 \cdot 52 \\
3666 \cdot 70 \\
3699 \cdot 98 \\
3733 \cdot 36\end{array}$ & $\begin{array}{l}33.012 \\
33.120 \\
33.228 \\
33.334 \\
33.440\end{array}$ & $\begin{array}{l}108 \cdot 3 \\
107 \cdot 7 \\
107 \cdot 1 \\
106 \cdot 4 \\
105 \cdot 8\end{array}$ & $\begin{array}{l}255 \\
256 \\
257 \\
258 \\
259\end{array}$ & $\begin{array}{l}5752.78 \\
5791.15 \\
5829.59 \\
5868.10 \\
5906.68\end{array}$ & $\begin{array}{l}38.340 \\
38.409 \\
38.477 \\
38.545 \\
38.612\end{array}$ & $\begin{array}{l}69 \cdot 2 \\
68 \cdot 5 \\
67 \cdot 9 \\
67.2 \\
66.5\end{array}$ & & & \\
\hline $\begin{array}{l}200 \\
201 \\
202 \\
203 \\
204\end{array}$ & $\begin{array}{l}3766 \cdot 86 \\
3800 \cdot 46 \\
3834 \cdot 16 \\
3867 \cdot 96 \\
3901.87\end{array}$ & $\begin{array}{l}33.546 \\
33.651 \\
33.755 \\
33.858 \\
33.961\end{array}$ & $\begin{array}{l}105 \cdot 1 \\
104 \cdot 5 \\
103 \cdot 8 \\
103 \cdot 2 \\
102.5\end{array}$ & $\begin{array}{l}260 \\
261 \\
262 \\
263 \\
264\end{array}$ & $\begin{array}{l}5945.33 \\
5984.04 \\
6022.81 \\
6061.65 \\
6100.56\end{array}$ & $\begin{array}{l}38.678 \\
38.743 \\
38.808 \\
38.872 \\
38.935\end{array}$ & $\begin{array}{l}65.8 \\
65 \cdot 1 \\
64 \cdot 3 \\
63.6 \\
62.8\end{array}$ & & & \\
\hline $\begin{array}{l}205 \\
206 \\
207 \\
208 \\
209\end{array}$ & $\begin{array}{l}3935.89 \\
3970.00 \\
4004.22 \\
4038.53 \\
4072.95\end{array}$ & $\begin{array}{l}34.063 \\
34.165 \\
34.266 \\
34.366 \\
34.466\end{array}$ & $\begin{array}{r}101.9 \\
101.2 \\
100.6 \\
99.9 \\
99.3\end{array}$ & $\begin{array}{l}265 \\
266 \\
267 \\
268 \\
269\end{array}$ & $\begin{array}{l}6139 \cdot 52 \\
6178.55 \\
6217.64 \\
6256.79 \\
6296.00\end{array}$ & $\begin{array}{l}38.998 \\
39.059 \\
39.120 \\
39.180 \\
39.239\end{array}$ & $\begin{array}{l}62.1 \\
61.3 \\
60.5 \\
59.6 \\
58.8\end{array}$ & & & \\
\hline $\begin{array}{l}210 \\
211 \\
212 \\
213 \\
214\end{array}$ & $\begin{array}{l}4107 \cdot 46 \\
4142 \cdot 08 \\
4176 \cdot 79 \\
4211 \cdot 60 \\
4246 \cdot 50\end{array}$ & $\begin{array}{l}34.565 \\
34.663 \\
34.761 \\
34.857 \\
34.954\end{array}$ & $\begin{array}{l}98.6 \\
98.0 \\
97 \cdot 3 \\
96.7 \\
96.0\end{array}$ & $\begin{array}{l}270 \\
271 \\
272 \\
273 \\
274\end{array}$ & $\begin{array}{l}6335.27 \\
6374.60 \\
6413.98 \\
6453.42 \\
6492.91\end{array}$ & $\begin{array}{l}39.298 \\
39.355 \\
39.412 \\
39.467 \\
39.522\end{array}$ & $\begin{array}{l}57.9 \\
57.0 \\
56.1 \\
55.1 \\
54.1\end{array}$ & & & \\
\hline $\begin{array}{l}215 \\
216 \\
217 \\
218 \\
219\end{array}$ & $\begin{array}{l}4281.51 \\
4316.60 \\
4351.79 \\
4387.08 \\
4422.46\end{array}$ & $\begin{array}{l}35.049 \\
35.144 \\
35.239 \\
35.333 \\
35.426\end{array}$ & $\begin{array}{l}95.3 \\
94.7 \\
94.0 \\
93.4 \\
92.7\end{array}$ & $\begin{array}{l}275 \\
276 \\
277 \\
278 \\
279\end{array}$ & $\begin{array}{l}6532.46 \\
6572.06 \\
6611.72 \\
6651.42 \\
6691.18\end{array}$ & $\begin{array}{l}39.575 \\
39.628 \\
39.679 \\
39.729 \\
39.778\end{array}$ & $\begin{array}{l}53.0 \\
51.9 \\
50.8 \\
49.6 \\
48.4\end{array}$ & & & \\
\hline $\begin{array}{l}220 \\
221 \\
222 \\
223 \\
224\end{array}$ & $\begin{array}{l}4457 \cdot 93 \\
4493 \cdot 49 \\
4529 \cdot 15 \\
4564 \cdot 90 \\
4600 \cdot 73\end{array}$ & $\begin{array}{l}35.518 \\
35.610 \\
35.701 \\
35.791 \\
35.881\end{array}$ & $\begin{array}{l}92 \cdot 1 \\
91.4 \\
90.7 \\
90.1 \\
89.4\end{array}$ & 280 & 6730.98 & 39.826 & $47 \cdot 1$ & & & \\
\hline $\begin{array}{l}225 \\
226 \\
227 \\
228 \\
229\end{array}$ & $\begin{array}{l}4636.66 \\
4672.67 \\
4708.77 \\
4744.96 \\
4781.24\end{array}$ & $\begin{array}{l}35 \cdot 970 \\
36 \cdot 059 \\
36 \cdot 146 \\
36 \cdot 233 \\
36 \cdot 320\end{array}$ & $\begin{array}{l}88.8 \\
88 \cdot 1 \\
87 \cdot 5 \\
86.8 \\
86.2\end{array}$ & & & & & & & \\
\hline $\begin{array}{l}230 \\
231 \\
232 \\
233 \\
234\end{array}$ & $\begin{array}{l}4817 \cdot 60 \\
4854 \cdot 05 \\
4890 \cdot 59 \\
4927.20 \\
4963 \cdot 90\end{array}$ & $\begin{array}{l}36 \cdot 406 \\
36.491 \\
36.575 \\
36.659 \\
36.743\end{array}$ & $\begin{array}{l}85 \cdot 5 \\
84 \cdot 8 \\
84 \cdot 2 \\
83.5 \\
82.9\end{array}$ & & & & & & & \\
\hline $\begin{array}{l}235 \\
236 \\
237 \\
238 \\
239\end{array}$ & $\begin{array}{l}5000 \cdot 69 \\
5037 \cdot 55 \\
5074.50 \\
5111.53 \\
5148.64\end{array}$ & $\begin{array}{l}36.825 \\
36.907 \\
36.988 \\
37.069 \\
37.149\end{array}$ & $\begin{array}{l}82.2 \\
81.6 \\
80.9 \\
80.3 \\
79.6\end{array}$ & & & & & & & \\
\hline 240 & 5185.83 & 37.228 & 79.0 & & & & & & & \\
\hline
\end{tabular}


$\underset{\mu V}{\boldsymbol{\mu}} \stackrel{\mathrm{V} / \boldsymbol{K}}{\mathrm{S}}$

0.00

$-0.15$

0.18

2. 09

3.59

5.43

7.58

10.03

12.75

15.74
19.00

$22 \cdot 50$

26.26

30.26

34.51

39.00

53.92

59.37

65.07

71.01

77.20

$83 \cdot 62$

$90 \cdot 29$

$97 \cdot 20$

$104 \cdot 36$

111.75

119.38

127.25

135.36

143.70

$152 \cdot 28$

$170 \cdot 12$

179.38

188.86

208.48

218.61

228.95

239.49
250.24

261.19

$272 \cdot 34$

283.68

306.93

318.83

330.92

343.18

$3 \times 5.62$

368.23

381.00

393.95

407.06

420.33

433.77

447.36

$461 \cdot 1$

-0.400
0.099
0.549
0.958

390.1

1.677

1. 998

$\begin{array}{ll}2.586 & 279.7 \\ 2.860 & 268.8\end{array}$

3.124

3.381

3.633
3.880

4. 125

4.368

4.610

5.09

5.094
5.335

5.577

5.820

6.062

6.548

6.790

$7 \cdot 032$

7.273

7.752

7.990

8.226

8.459

8.691

8.920

9.147

9.371

9.592

9.809

10.024

10.236

10.444

10.649

10.851
11.049

11.245

11.437

11.625

11.993

$260 \cdot 3$

254.0

249.3

243.8

242.5

$241 \cdot 8$

241.5

$241 \cdot 6$

241.8

$242 \cdot 2$

242.5

242.7

242.7

$242 \cdot 6$

242.2

$241 \cdot 6$

240.8

238.3

236.7

234.8

232.7

230.4

225.2

222.4

219.4

213.2

210.0

$206 \cdot 7$

203.4

200.1

196.8

193.5

190.3

187.1

181.0

12.173

178.0

175.2

172.5

169.8

167.3

164.9

162.6

160.4

158.4

13.514

13.671

156.4
T

K $\quad \underset{\mu V}{E}$

$60 \quad 461.11$

$61 \quad 475.01$

$62 \quad 489.07$

503.28

517.64

65

532.14

546.79

561.59

576.54
591.62

606.86

622.23

637.74

653.40

669.19

$685 \cdot 13$

$701 \cdot 20$

$733 \cdot 76$

$750 \cdot 24$

766.87

783.63

800.52

817.55

834.72

852.02

869.46

887.03

904.74

922.58

940.56

958.66

976.91

995.28

1013.79

1032.43

1051.20

1070.11

1108.31

1127.61

1147.04

1166.60

1186.29

1226.07

1246.15

1266.36

1307.17

1327.76

1348.49

1369.34

1390.32

1411.43

1432.66

1454.02

1475.51

1497.13

1518.87

1540.74

$S$
$\mu V / K$
13.826
13.980
14.132
14.283
14.432
14.580
14.726
14.872
15.016
15.159

d $S / d$

154.6

152.9

149.8

148.4

147.1

146.0

144.9

143.9
142.9

15.302

15.444

15.584

$\begin{array}{ll}15.584 & 140.6\end{array}$

15.864

16.003

16.142

16.280

16.417
16.555

142.1

$142 \cdot 1$
$141 \cdot 3$

139.3

138.8

$138 \cdot 3$

137.8

137.4

16.691

16.828

16.964

17.100

17.370

17.505

17.640

17.908

18.042

18.175

18.442

18.574

18.707

18.839

18.971

19.102

19.234 


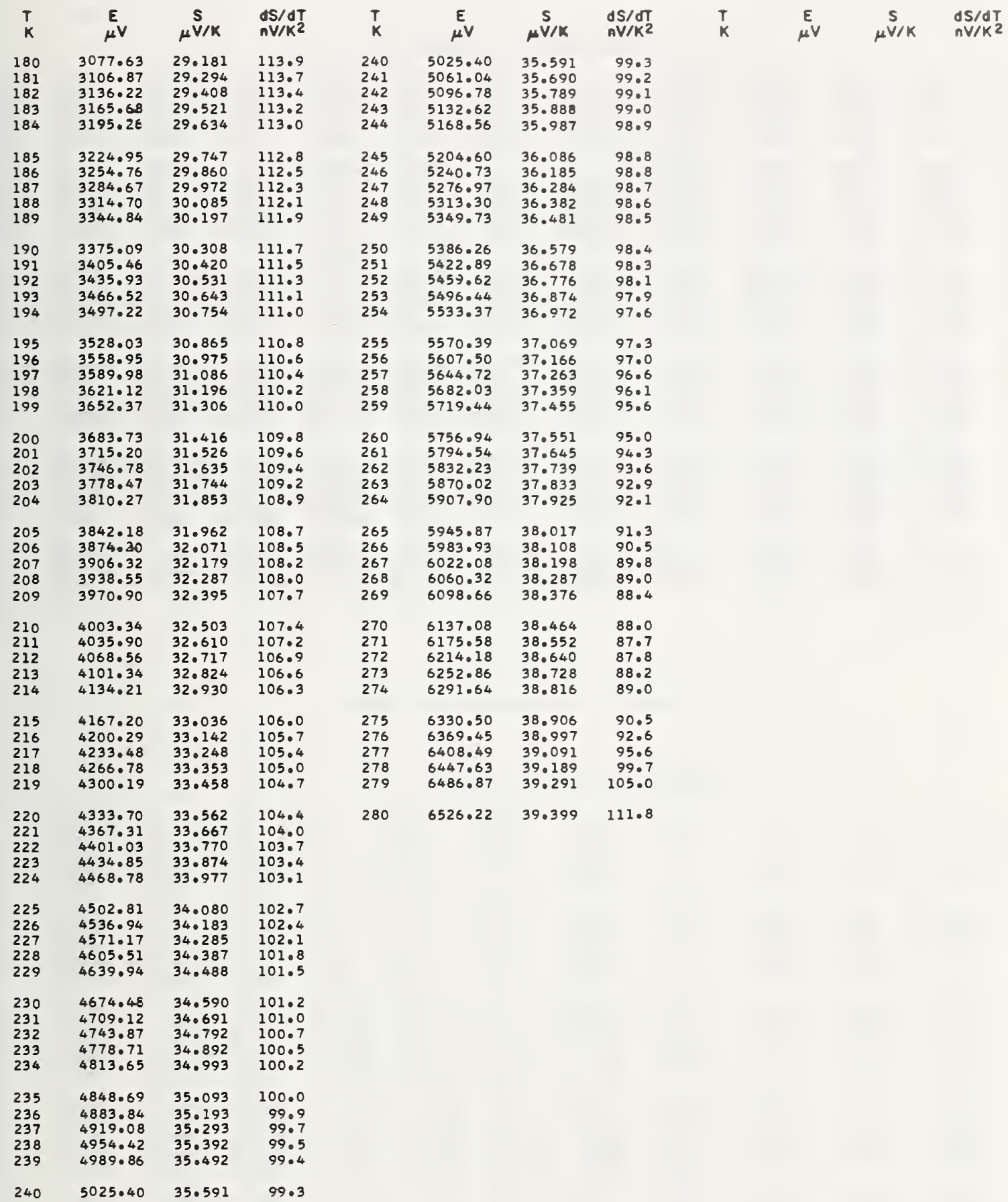


THERMOELECTRIC VOLTAGE IN ABSOLUTE $\mu \mathrm{V}$

$\begin{array}{rr}0 & 0.0 \\ 10 & 23.9 \\ 20 & 90.1 \\ 30 & 193.2 \\ 40 & 331.5 \\ & \\ 50 & 502.9 \\ 60 & 704.8 \\ 70 & 934.8 \\ 80 & 1190.7 \\ 90 & 1470.9 \\ 100 & 1774.1 \\ 110 & 2099.2 \\ 120 & 2445.1 \\ 130 & 2811.1 \\ 140 & 3196.2 \\ & \\ 150 & 3599.6 \\ 160 & 4020.8 \\ 170 & 4459.1 \\ 180 & 4913.8 \\ 190 & 5384.5 \\ 200 & 5870.3 \\ 210 & 6370.9 \\ 220 & 6885.5 \\ 230 & 7413.7 \\ 240 & 7955.0 \\ & \\ 250 & 8508.9 \\ 260 & 9075.0 \\ 270 & 9652.9 \\ 280 & 10241.5 \\ & \\ & \\ & \\ & \\ & \\ & \\ & \\ 170 & \end{array}$

K

0
0.1

28.7

98.8

205.5

347.2

521.7

$726 \cdot 6$

959.3

1217.7

1500.2

1805.6

2132,8

2480.8

2848.7

3641.0

4063.9

$4503 \cdot 8$

4960.2

5432.4

5919.7 6421.7 6937.7 7467.2

$8009 \cdot 8$

8564.9 9132.2 9711.3

1

0.8
34.0
107.8
218.1

363.2

540.9

748.7

984.0

1244.9

1529.8

1837.4

2166.7

2516.8

2886.6

3682.5

4107.1

4548.7

5006. 7

5480.4

5969.3

6472.7

6990.0

7520.9

$8064 \cdot 7$

8621.1

9189.6

9769.8

2

3

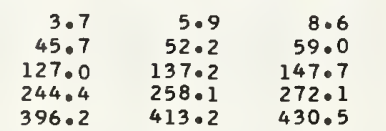

\section{4}

771.0

1272.3

1559.5

$1869 \cdot 4$ 2200.8

2552.9

3315.3

3724.2

4150.5

5053.4

5528.6

6019.0

6523.8

7042.5

7574.7

8119.8

8677.4

$9247 \cdot 1$

580.1

793.6

1034.2

1589.5

2235 . 1

2589.2

2962.9

3355.4

3766.0

4639.0

5100.2

5577.0

6068.8

6575.0

$7095 \cdot 1$

8175.0

8733.9

$9304 \cdot 7$

600.2

816.5

1059.7

1327.9
1619.7

1933.9

2269.6

2625.7

$3001 \cdot 3$

3808.0

4237.8

4684.4

5147.2

5625.5

6118.8

6626.4

7147.9
7682.7

8230.4

8790.4

9362.5

620.6
839.6

1085.4

1650.1

1966.6

2304.3

2662.4

3039.9

$3850 \cdot 3$

4281.8

4730.0

5194.3

5674.2

6168.9

6678.0

7200.8

7736.9

8285.8

8847.1

9420.3

10004.9
11.8

66.2

158.5

286.4

448.1

641.2

863.0

1111.3

1384.4

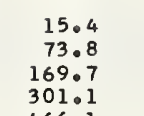

19.4 81.7
181.3

$181 \cdot 3$

484.3

662.1

886.7

683.3

910.6

1164.0

1413.0

1711.7

$1441 \cdot 8$
1742.8

1999.4

2339.2

2699.3

3078.7

2032.4

2374.3

2736.3

3117.7

2065. 7

2409.6

2773.6

3156.8

3476.7

3892.6

3517.5

3558 .

3977.9

4414.5

$4821.6 \quad 4867.6$

5241.65289

5336.7

$5821 \cdot 1$

6219.

5772.0

6729.6

7253.8

7791.2

6269.6

6320.2

7307.0

7845.7

6833.

7360.3

7900 .

0903

8397.1

8452.9

8960.89017 .8

$\begin{array}{rr}948.3 \quad 9536.4 & 9594.6\end{array}$

$10123.0 \quad 10182.2$
23.9

90.1

193.2

331.5

502.9

704.8

934.8

1190.7

1470.9

1774.1

2099.2

2445. 1

2811.1

$3196 \cdot 2$

3599.6

4020.8

4459.1

4913.8

5384.5

$5870 \cdot 3$

6370.9

6885.5

$7413 \cdot 7$

7955.0

8508.9

9075.0

9652.9

10

8

9

TABLE 16. Type K-reduced precision tables, E(T)
3

THERMOELECTRIC VOLTAGE IN ABSOLUTE $\mu \mathrm{V}$

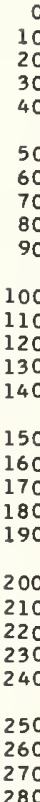

0.0

$10 \cdot 8$

$94 \cdot 2$

$169 \cdot 2$

266.0

383.6

520.8

676.8

1041.9

1249.6

1473.2

1712.2

1966.1

2234.2

2515.9

2810.7

$3117 \cdot 8$

3766.9

4107.5

4457.9

4817.6

5185.8

5562.0

5945.3

6335.3

6731.0

0.8
15.3
50.2
107.4
186.9
287.9
409.5
550.5
710.2
887.6

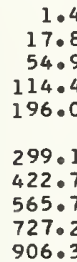

2.2
20.5
59.9
121.5
205.4
310.6
436.2
581.0
744.3
925.2


TABLE 17. Type T-reduced precision tables, E(T)

THERMOELECTRIC VOLTAGE IN ABSOLUTE $\mu \mathrm{V}$

$\begin{array}{rrr}0.0 & -0.1 & 0.2 \\ 15.7 & 19.0 & 22.5 \\ 59.4 & 65.1 & 71.0 \\ 127.3 & 135.4 & 143.7 \\ 218.6 & 228.9 & 239.5 \\ & & \\ 330.9 & 343.2 & 355.6 \\ 461.1 & 475.0 & 489.1 \\ 606.9 & 622.2 & 637.7 \\ 766.9 & 783.6 & 800.5 \\ 940.6 & 958.7 & 976.9 \\ 1127.6 & 1147.0 & 1166.6 \\ 1327.8 & 1348.5 & 1369.3 \\ 1540.7 & 1562.7 & 1584.9 \\ 1766.3 & 1789.6 & 1812.9 \\ 2004.3 & 2028.8 & 2053.4 \\ & & \\ 2254.7 & 2280.4 & 2306.2 \\ 2517.2 & 2544.1 & 2571.1 \\ 2791.6 & 2819.7 & 2847.9 \\ 3077.6 & 3106.9 & 3136.2 \\ 3375.1 & 3405.5 & 3435.9 \\ 3683.7 & 3715.2 & 3746.8 \\ 4003.3 & 4035.9 & 4068.6 \\ 4333.7 & 4367.3 & 4401.0 \\ 4674.5 & 4709.1 & 4743.9 \\ 5025.4 & 5061.0 & 5096.8 \\ 5386.3 & 5422.9 & 5459.6 \\ 5756.9 & 5794.5 & 5832.2 \\ 6137.1 & 6175.6 & 6214.2 \\ 6526.2 & & \\ & & \end{array}$

0

2

0.9
26.3
77.2
152.3
250.2
368.2
503.3
653.4
817.6
995.3

1186.3 1390.3 1607.1 1836.4 2078.1

2332.1 2598.2

2876.2 3165.7 3466.5

3778.5 4101.3 4434.9 4778.7 5132.6

5496.4 5870.0 6252.9
1013.8

1206.1 1411.4 1629.5 1860.0

2103.0

2358.2 2904.6

$\begin{array}{ll}3195.3 & 3225.0 \\ 3497.2 & 3528.0\end{array}$

$3810.3 \quad 3842.2$ $4134.2 \quad 4167.2$ $4468.8 \quad 4502.8$ $4813.7 \quad 4848.7$

$5168.6 \quad 5204.6$

5533.4 6291.6

2.1
30.3
83.6
161.1
261.2
381.0
517.6
669.2
834.7

6330.5

$3.6 \quad 5.4$ 34.5 170.1

272.3

$394 \cdot 0$

685.1

1032.4

1226.1 1432.7 1883.8

2128.0

2652.9

39.0
97.2

179.4

283.7

407.1

546.8

701.2

869.5

1051.2

1246.1

1454.0

1674.6

1907.6

2153.1

2410.7

2680.4

2961.8

3254.8

3558.9

3874.2

4200.3

4536.9

4883.8

5240.7

5607.5

5983.9

6369.4

7.6
43.7
104.4
188.9
295.2
420.3
561.6
717.4
887.0

1070.1

1266.4

1475.5

1697.3

1931.6

2178.3

2437.1

2708.0

2990.6

3284.7

3590.0

3906.3

4233.5

4571.2

4919.1

5277.0

5644.7

6022.1

6408.5
8

9

10

$\begin{array}{rrrr}10.0 & 12.7 & 15.7 & 0 \\ 48.7 & 53.9 & 59.4 & 10 \\ 111.7 & 119.4 & 127.3 & 20 \\ 198.6 & 208.5 & 218.6 & 30 \\ 306.9 & 318.8 & 330.9 & 40 \\ & & & \\ 433.8 & 447.4 & 461.1 & 50 \\ 576.5 & 591.6 & 606.9 & 60 \\ 733.8 & 750.2 & 766.9 & 70 \\ 904.7 & 922.6 & 940.6 & 80 \\ 1089.1 & 1108.3 & 1127.6 & 90 \\ 1286.7 & 1307.2 & 1327.8 & 100 \\ 1497.1 & 1518.9 & 1540.7 & 110 \\ 1720.2 & 1743.2 & 1766.3 & 120 \\ 1955.7 & 1980.0 & 2004.3 & 130 \\ 2203.6 & 2229.1 & 2254.7 & 140 \\ & & & \\ 2463.7 & 2490.4 & 2517.2 & 150 \\ 2735.7 & 2763.6 & 2791.6 & 160 \\ 3019.5 & 3048.5 & 3077.6 & 170 \\ 3314.7 & 3344.8 & 3375.1 & 180 \\ 3621.1 & 3652.4 & 3683.7 & 190 \\ 3938.6 & 3970.9 & 4003.3 & 200 \\ 4266.8 & 4300.2 & 4333.7 & 210 \\ 4605.5 & 4639.9 & 4674.5 & 220 \\ 4954.4 & 4989.9 & 5025.4 & 230 \\ 5313.3 & 5349.7 & 5386.3 & 240 \\ 5682.0 & 5719.4 & 5756.9 & 250 \\ 6060.3 & 6098.7 & 6137.1 & 260 \\ 6447.6 & 6486.9 & 6526.2 & 270 \\ & & & 280\end{array}$

3

4

5

6

7

8

9

10
K

k




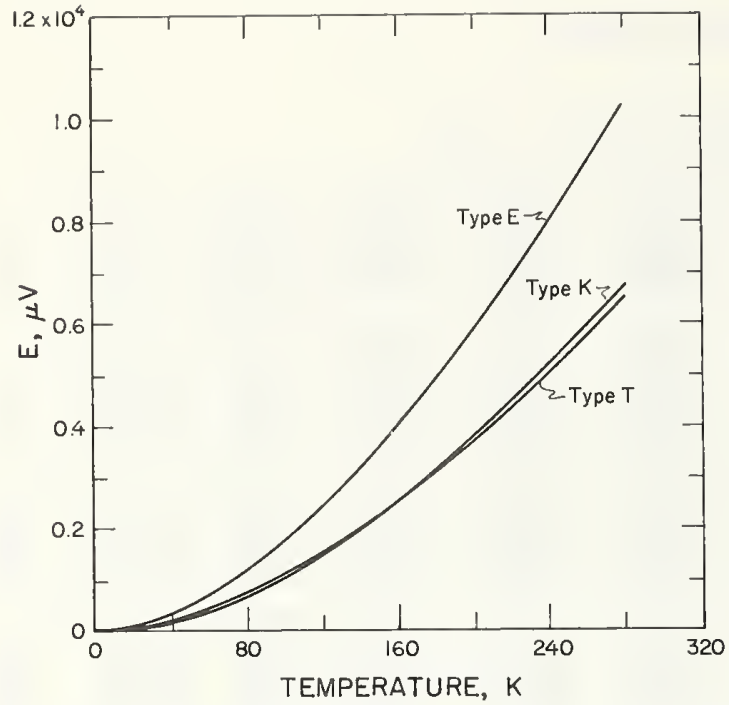

Figure 12. Thermoelectric voltage for primary thermocouple types, $E, K$, and $T$.

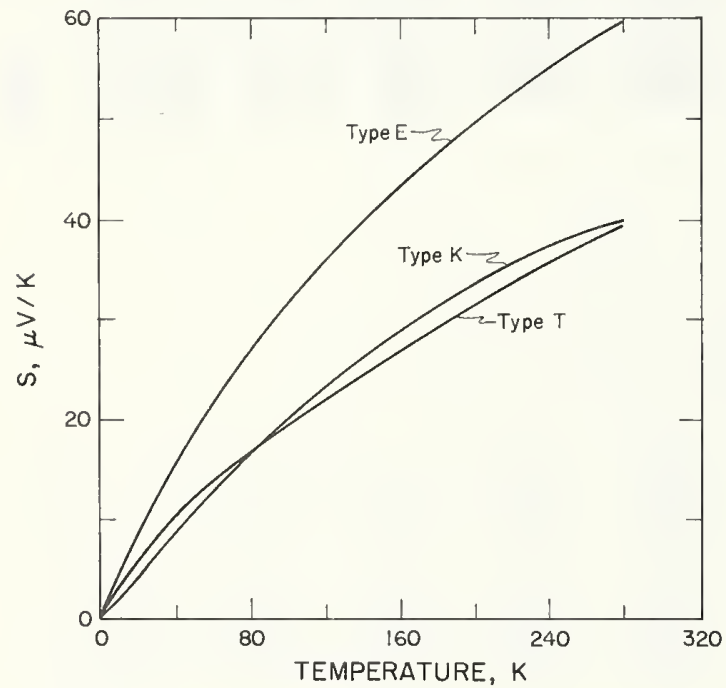

FIGURE 13. Seebeck coefficient for primary thermocouple types $E, K$, and $T$.

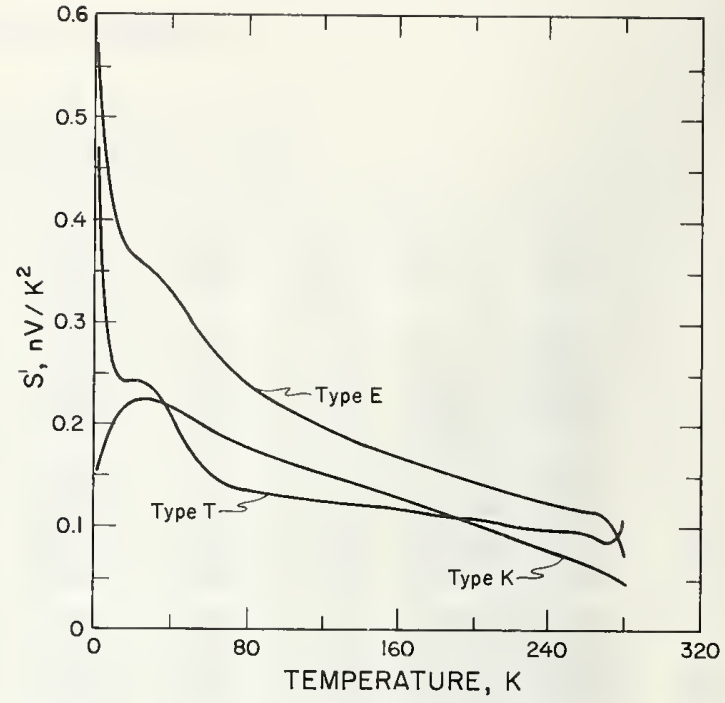

FIGURE 14. - Derivative of the Seebeck coefficient for primary thermocouple types $E, K$, and $T$. 
TABlE 18. Type E-reduced precision tables, T(E)

.06

.07

.08

.09

.10

$\mathrm{mV}$

TEMPERATURES IN K

\begin{tabular}{|c|c|c|c|c|c|c|c|c|c|c|c|c|}
\hline $\begin{array}{l}-9.80 \\
-9.70 \\
-9.60 \\
-9.50\end{array}$ & $\begin{array}{l}12.58 \\
25.01 \\
33.46 \\
40.37\end{array}$ & $\begin{array}{l}10.70 \\
24.02 \\
32.70 \\
39.72\end{array}$ & $\begin{array}{r}8.47 \\
23.00 \\
31.93 \\
39.07\end{array}$ & $\begin{array}{r}5.51 \\
21.94 \\
31.14 \\
38.41\end{array}$ & $\begin{array}{l}20.83 \\
30.33 \\
37.74\end{array}$ & $\begin{array}{l}19.66 \\
29.50 \\
37.05\end{array}$ & $\begin{array}{l}18.44 \\
28.65 \\
36.36\end{array}$ & $\begin{array}{l}17.14 \\
27.78 \\
35.66\end{array}$ & $\begin{array}{l}15.74 \\
26.88 \\
34.94\end{array}$ & $\begin{array}{l}14.24 \\
25.96 \\
34.21\end{array}$ & $\begin{array}{l}12.58 \\
25.01 \\
33.46\end{array}$ & $\begin{array}{l}-9.80 \\
-9.70 \\
-9.60 \\
-9.50\end{array}$ \\
\hline $\begin{array}{l}-9.40 \\
-9.30 \\
-9.20 \\
-9.10 \\
-9.00\end{array}$ & $\begin{array}{l}46.38 \\
51.81 \\
56.81 \\
61.48 \\
65.90\end{array}$ & $\begin{array}{l}45.81 \\
51.29 \\
56.32 \\
61.03 \\
65.47\end{array}$ & $\begin{array}{l}45.23 \\
50.76 \\
55.84 \\
60.57 \\
65.03\end{array}$ & $\begin{array}{l}44.65 \\
50.23 \\
55.35 \\
60.11 \\
64.60\end{array}$ & $\begin{array}{l}44.06 \\
49.70 \\
54.85 \\
59.65 \\
64.16\end{array}$ & $\begin{array}{l}43.46 \\
49 \cdot 16 \\
54.35 \\
59 \cdot 18 \\
63.72\end{array}$ & $\begin{array}{l}42.86 \\
48.61 \\
53.85 \\
58.71 \\
63.28\end{array}$ & $\begin{array}{l}42.25 \\
48.06 \\
53.35 \\
58.24 \\
62.83\end{array}$ & $\begin{array}{l}41.63 \\
47.51 \\
52.84 \\
57.77 \\
62.38\end{array}$ & $\begin{array}{l}41.00 \\
46.95 \\
52.33 \\
57.29 \\
61.94\end{array}$ & $\begin{array}{l}40.37 \\
46.38 \\
51.81 \\
56.81 \\
61.48\end{array}$ & $\begin{array}{l}-9.40 \\
-9.30 \\
-9.20 \\
-9.10 \\
-9.00\end{array}$ \\
\hline $\begin{array}{l}-8.90 \\
-8.80 \\
-8.70 \\
-8.50 \\
-8.50\end{array}$ & $\begin{array}{l}70.10 \\
74.12 \\
77.99 \\
81.72 \\
85.33\end{array}$ & $\begin{array}{l}69.69 \\
73.73 \\
77.61 \\
81.35 \\
84.98\end{array}$ & $\begin{array}{l}69.27 \\
73.33 \\
77.22 \\
80.98 \\
84.62\end{array}$ & $\begin{array}{l}68.86 \\
72.93 \\
76.84 \\
80.61 \\
84.26\end{array}$ & $\begin{array}{l}68.44 \\
72.53 \\
76.46 \\
80.24 \\
83.90\end{array}$ & $\begin{array}{l}68.02 \\
72.13 \\
76.07 \\
79.87 \\
83.54\end{array}$ & $\begin{array}{l}67.60 \\
71.73 \\
75.68 \\
79.50 \\
83.18\end{array}$ & $\begin{array}{l}67 \cdot 18 \\
71 \cdot 32 \\
75 \cdot 30 \\
79 \cdot 12 \\
82.82\end{array}$ & $\begin{array}{l}66.75 \\
70.92 \\
74.90 \\
78.74 \\
82.45\end{array}$ & $\begin{array}{l}66.33 \\
70.51 \\
74.51 \\
78.37 \\
82.09\end{array}$ & $\begin{array}{l}65.90 \\
70.10 \\
74.12 \\
77.99 \\
81.72\end{array}$ & $\begin{array}{l}-8.90 \\
-8.80 \\
-8.70 \\
-8.60 \\
-8.50\end{array}$ \\
\hline $\begin{array}{l}-8.40 \\
-8.30 \\
-8.20 \\
-8.10 \\
-8.00\end{array}$ & $\begin{array}{r}88.84 \\
92.25 \\
95.58 \\
98.82 \\
101.99\end{array}$ & $\begin{array}{r}88.49 \\
91.91 \\
95.25 \\
98.50 \\
101.68\end{array}$ & $\begin{array}{r}88.15 \\
91.58 \\
94.92 \\
98.18 \\
101.37\end{array}$ & $\begin{array}{r}87.80 \\
91.24 \\
94.59 \\
97.86 \\
101.05\end{array}$ & $\begin{array}{r}87.45 \\
90.90 \\
94.26 \\
97.53 \\
100.73\end{array}$ & $\begin{array}{r}87.10 \\
90.56 \\
93.92 \\
97.21 \\
100.42\end{array}$ & $\begin{array}{r}86.75 \\
90.22 \\
93.59 \\
96.88 \\
100.10\end{array}$ & $\begin{array}{l}86.40 \\
89.87 \\
93.26 \\
96.56 \\
99.78\end{array}$ & $\begin{array}{l}86.04 \\
89.53 \\
92.92 \\
96.23 \\
99.46\end{array}$ & $\begin{array}{l}85.69 \\
89.19 \\
92.59 \\
95.90 \\
99.14\end{array}$ & $\begin{array}{l}85.33 \\
88.84 \\
92.25 \\
95.58 \\
98.82\end{array}$ & $\begin{array}{l}-8.40 \\
-8.30 \\
-8.20 \\
-8.10 \\
-8.00\end{array}$ \\
\hline $\begin{array}{l}-7.90 \\
-7.80 \\
-7.70 \\
-7.60 \\
-7.50\end{array}$ & $\begin{array}{l}105 \cdot 10 \\
108 \cdot 14 \\
111 \cdot 13 \\
114.06 \\
116 \cdot 94\end{array}$ & $\begin{array}{l}104.79 \\
107.84 \\
110.83 \\
113.77 \\
116.66\end{array}$ & $\begin{array}{l}104 \cdot 48 \\
107 \cdot 54 \\
110 \cdot 54 \\
113 \cdot 48 \\
116 \cdot 37\end{array}$ & $\begin{array}{l}104.18 \\
107.24 \\
110.24 \\
113.19 \\
116.08\end{array}$ & $\begin{array}{l}103.87 \\
106.93 \\
109.94 \\
112.90 \\
115.80\end{array}$ & $\begin{array}{l}103.56 \\
106.63 \\
109.64 \\
112.60 \\
115.51\end{array}$ & $\begin{array}{l}103 \cdot 24 \\
106 \cdot 33 \\
109 \cdot 35 \\
112 \cdot 31 \\
115 \cdot 22\end{array}$ & $\begin{array}{l}102.93 \\
106.02 \\
109.05 \\
112.02 \\
114.93\end{array}$ & $\begin{array}{l}102.62 \\
105.71 \\
108.75 \\
111.72 \\
114.64\end{array}$ & $\begin{array}{l}102 \cdot 31 \\
105 \cdot 41 \\
108 \cdot 45 \\
111 \cdot 43 \\
114 \cdot 35\end{array}$ & $\begin{array}{l}101.99 \\
105 \cdot 10 \\
108 \cdot 14 \\
111.13 \\
114.06\end{array}$ & $\begin{array}{l}-7.90 \\
-7.80 \\
-7.70 \\
-7.60 \\
-7.50\end{array}$ \\
\hline $\begin{array}{l}-7.40 \\
-7.30 \\
-7.20 \\
-7.10 \\
-7.00\end{array}$ & $\begin{array}{l}119.78 \\
122.57 \\
125.32 \\
128.02 \\
130.69\end{array}$ & $\begin{array}{l}119.50 \\
122.29 \\
125.04 \\
127.75 \\
130.43\end{array}$ & $\begin{array}{l}119.21 \\
122.01 \\
124.77 \\
127.49 \\
130.16\end{array}$ & $\begin{array}{l}118.93 \\
121.74 \\
124.50 \\
127.22 \\
129.90\end{array}$ & $\begin{array}{l}118 \cdot 65 \\
121 \cdot 46 \\
124 \cdot 22 \\
126.95 \\
129 \cdot 63\end{array}$ & $\begin{array}{l}118.37 \\
121.18 \\
123.95 \\
126.67 \\
129.36\end{array}$ & $\begin{array}{l}118.08 \\
120.90 \\
123.67 \\
126.40 \\
129.10\end{array}$ & $\begin{array}{l}117.80 \\
120.62 \\
123.40 \\
126.13 \\
128.83\end{array}$ & $\begin{array}{l}117.51 \\
120.34 \\
123.12 \\
125.86 \\
128.56\end{array}$ & $\begin{array}{l}117.23 \\
120.06 \\
122.84 \\
125.59 \\
128.29\end{array}$ & $\begin{array}{l}116.94 \\
119.78 \\
122.57 \\
125.32 \\
128.02\end{array}$ & $\begin{array}{l}-7.40 \\
-7.30 \\
-7.20 \\
-7.10 \\
-7.00\end{array}$ \\
\hline $\begin{array}{l}-6.90 \\
-6.80 \\
-6.70 \\
-6.60 \\
-6.50\end{array}$ & $\begin{array}{l}133.33 \\
135.93 \\
138.50 \\
141.04 \\
143.55\end{array}$ & $\begin{array}{l}133.07 \\
135.67 \\
138.24 \\
140.79 \\
143.30\end{array}$ & $\begin{array}{l}132.81 \\
135.41 \\
137.99 \\
140.53 \\
143.05\end{array}$ & $\begin{array}{l}132.54 \\
135.15 \\
137.73 \\
140.28 \\
142.80\end{array}$ & $\begin{array}{l}132.28 \\
134.89 \\
137.48 \\
140.03 \\
142.55\end{array}$ & $\begin{array}{l}132.02 \\
134.63 \\
137.22 \\
139.77 \\
142.30\end{array}$ & $\begin{array}{l}131.75 \\
134.37 \\
136.96 \\
139.52 \\
142.05\end{array}$ & $\begin{array}{l}131.49 \\
134.11 \\
136.70 \\
139.26 \\
141.79\end{array}$ & $\begin{array}{l}131.22 \\
133.85 \\
136.45 \\
139.01 \\
141.54\end{array}$ & $\begin{array}{l}130.96 \\
133.59 \\
136.19 \\
138.76 \\
141.29\end{array}$ & $\begin{array}{l}130.69 \\
133.33 \\
135.93 \\
138.50 \\
141.04\end{array}$ & $\begin{array}{l}-6.90 \\
-6.80 \\
-6.70 \\
-6.60 \\
-6.50\end{array}$ \\
\hline $\begin{array}{l}-6.40 \\
-6.30 \\
-6.20 \\
-6.10 \\
-6.00\end{array}$ & $\begin{array}{l}146.03 \\
148.48 \\
150.91 \\
153.31 \\
155.69\end{array}$ & $\begin{array}{l}145.78 \\
148.24 \\
150.67 \\
153.07 \\
155.45\end{array}$ & $\begin{array}{l}145.53 \\
147.99 \\
150.43 \\
152.83 \\
155.22\end{array}$ & $\begin{array}{l}145.29 \\
147.75 \\
150.18 \\
152.59 \\
154.98\end{array}$ & $\begin{array}{l}145.04 \\
147.50 \\
149.94 \\
152.35 \\
154.74\end{array}$ & $\begin{array}{l}144.79 \\
147.26 \\
149.70 \\
152.11 \\
154.51\end{array}$ & $\begin{array}{l}144.54 \\
147.01 \\
149.46 \\
151.87 \\
154.27\end{array}$ & $\begin{array}{l}144.29 \\
146.77 \\
149.21 \\
151.63 \\
154.03\end{array}$ & $\begin{array}{l}144.05 \\
146.52 \\
148.97 \\
151.39 \\
153.79\end{array}$ & $\begin{array}{l}143.80 \\
146.27 \\
148.73 \\
151.15 \\
153.55\end{array}$ & $\begin{array}{l}143.55 \\
146.03 \\
148.48 \\
150.91 \\
153.31\end{array}$ & $\begin{array}{l}-6.40 \\
-6.30 \\
-6.20 \\
-6.10 \\
-6.00\end{array}$ \\
\hline
\end{tabular}

$m V$

.00

.01

.02

.03

.04

.05

.06

.07

.08

.09

.10

$m V$ 
TABLE 18. Type E-reduced precision tables, T(E)-Continued

m V

.01

.02

.03

.04

.05

TEMPERATURES IN K

\begin{tabular}{|c|c|c|c|c|c|c|c|c|c|c|c|c|}
\hline-6.00 & 155.69 & 155.45 & 155.22 & 154.98 & $154 \cdot 74$ & 154.51 & 154.27 & 154.03 & 153.79 & 153.55 & 153.31 & -6.00 \\
\hline$-5 \cdot 90$ & 158.05 & 157.81 & 157.58 & 157.34 & 157.11 & 156.87 & 156.64 & 156.40 & $156 \cdot 16$ & 155.93 & 155.69 & -5.90 \\
\hline$-5 \cdot 80$ & 160.38 & 160.15 & 159.92 & 159.68 & 159.45 & 159.22 & 158.98 & 158.75 & $158 \cdot 52$ & $158 \cdot 28$ & 158.05 & -5.80 \\
\hline-5.70 & 162.69 & $162 \cdot 46$ & 162.23 & 162.00 & 161.77 & 161.54 & 161.31 & 161.08 & 160.85 & 160.61 & 160.38 & -5.70 \\
\hline$-5 \cdot 60$ & 164.99 & 164.76 & 164.53 & $164 \cdot 30$ & 164.07 & 163.84 & 163.61 & $163 \cdot 38$ & 163.15 & 162.92 & 162.69 & -5.60 \\
\hline-5.50 & 167.26 & 167.03 & 166.80 & 166.58 & 166.35 & 166.12 & 165.90 & 165.67 & 165.44 & 165.21 & 164.99 & -5.50 \\
\hline$-5 \cdot 40$ & 169.51 & 169.29 & 169.06 & 168.84 & 168.61 & 168.39 & 168.16 & 167.94 & 167.71 & 167.48 & $167 \cdot 26$ & $-5 \cdot 40$ \\
\hline$-5 \cdot 30$ & 171.74 & 171.52 & 171.30 & 171.08 & 170.85 & 170.63 & 170.41 & 170.18 & 169.96 & 169.73 & 169.51 & $-5 \cdot 30$ \\
\hline$-5 \cdot 20$ & 173.96 & 173.74 & 173.52 & 173.30 & 173.08 & 172.85 & 172.63 & 172.41 & 172.19 & 171.97 & 171.74 & -5.20 \\
\hline$-5 \cdot 10$ & 176.16 & 175.94 & 175.72 & 175.50 & 175.28 & 175.06 & 174.84 & 174.62 & 174.40 & $174 \cdot 18$ & 173.96 & -5.10 \\
\hline-5.00 & 178.34 & 178.12 & 177.90 & 177.69 & 177.47 & 177.25 & 177.03 & 176.81 & 176.60 & 176.38 & 176.16 & -5.00 \\
\hline-4.90 & 180.51 & 180.29 & 180.07 & 179.86 & 179.64 & 179.42 & 179.21 & 178.99 & 178.77 & 178.56 & $178 \cdot 34$ & -4.90 \\
\hline-4.80 & 182.65 & $182 \cdot 44$ & 182.23 & 182.01 & 181.80 & 181.58 & 181.37 & 181.15 & $180 \cdot 94$ & $180 \cdot 72$ & 180.51 & -4.80 \\
\hline$-4 \cdot 70$ & 184.79 & 184.58 & 184.36 & 184.15 & 183.94 & 183.72 & 183.51 & 183.30 & 183.08 & 182.87 & 182.65 & -4.70 \\
\hline$-4 \cdot 60$ & 186.91 & $186 \cdot 70$ & 186.48 & 186.27 & 186.06 & 185.85 & 185.64 & 185.43 & 185.21 & 185.00 & 184.79 & -4.60 \\
\hline$-4 \cdot 50$ & 189.01 & 188.80 & 188.59 & $188 \cdot 38$ & 188.17 & 187.96 & 187.75 & 187.54 & 187.33 & 187.12 & 186.91 & -4.50 \\
\hline$-4 \cdot 40$ & 191.10 & 190.89 & 190.68 & 190.48 & 190.27 & 190.06 & 189.85 & 189.64 & 189.43 & 189.22 & 189.01 & $-4 \cdot 40$ \\
\hline$-4 \cdot 30$ & 193.18 & 192.97 & 192.76 & 192.56 & 192.35 & 192.14 & 191.93 & 191.73 & 191.52 & 191.31 & 191.10 & $-4 \cdot 30$ \\
\hline$-4 \cdot 20$ & 195.24 & 195.03 & 194.83 & 194.62 & 194.42 & $194 \cdot 21$ & 194.00 & 193.80 & 193.59 & 193.38 & 193.18 & $-4 \cdot 20$ \\
\hline$-4 \cdot 10$ & 197.29 & 197.09 & 196.88 & 196.68 & 196.47 & 196.27 & 196.06 & 195.86 & 195.65 & 195.45 & 195.24 & -4.10 \\
\hline-4.00 & 199.33 & 199.12 & 198.92 & 198.72 & 198.51 & 198.31 & 198.11 & 197.90 & 197.70 & 197.49 & 197.29 & -4.00 \\
\hline-3.90 & 201.35 & 201.15 & 200.95 & 200.75 & $200 \cdot 54$ & 200.34 & $200 \cdot 14$ & 199.94 & 199.73 & 199.53 & $199 \cdot 33$ & -3.90 \\
\hline-3.80 & 203.37 & $203 \cdot 17$ & 202.96 & 202.76 & 202.56 & $202 \cdot 36$ & 202.16 & 201.96 & 201.76 & 201.56 & 201.35 & -3.80 \\
\hline-3.70 & 205.37 & 205.17 & 204.97 & 204.77 & 204.57 & 204.37 & $204 \cdot 17$ & 203.97 & 203.77 & 203.57 & 203.37 & -3.70 \\
\hline-3.60 & 207.36 & 207.16 & 206.96 & 206.76 & 206.56 & 206.36 & 206.17 & 205.97 & 205.77 & 205.57 & 205.37 & -3.60 \\
\hline-3.50 & $209 \cdot 34$ & $209 \cdot 14$ & $208 \cdot 94$ & 208.74 & $208 \cdot 55$ & 208.35 & $208 \cdot 15$ & 207.95 & 207.75 & 207.56 & $207.3 t$ & -3.50 \\
\hline$-3 \cdot 40$ & 211.30 & 211.11 & 210.91 & 210.72 & 210.52 & 210.32 & 210.13 & 209.93 & 209.73 & 209.53 & $209 \cdot 34$ & -3.40 \\
\hline$-3 \cdot 30$ & $213 \cdot 26$ & 213.07 & 212.87 & 212.68 & $212 \cdot 48$ & 212.28 & 212.09 & 211.89 & 211.70 & 211.50 & 211.30 & -3.30 \\
\hline$-3 \cdot 20$ & $215 \cdot 21$ & 215.02 & $214 \cdot 82$ & 214.63 & $214 \cdot 43$ & $214 \cdot 24$ & 214.04 & 213.85 & 213.65 & 213.46 & 213.26 & -3.20 \\
\hline$-3 \cdot 10$ & $217 \cdot 15$ & 216.95 & $216 \cdot 76$ & 216.57 & 216.37 & $216 \cdot 18$ & 215.99 & 215.79 & 215.60 & 215.40 & 215.21 & -3.10 \\
\hline$-3 \cdot 00$ & 219.07 & $218 \cdot 88$ & $218 \cdot 69$ & $218 \cdot 50$ & $218 \cdot 30$ & 218.11 & 217.92 & $217 \cdot 73$ & 217.53 & 217.34 & $217 \cdot 15$ & -3.00 \\
\hline$-2 \cdot 90$ & 220.99 & 220.80 & $220 \cdot 61$ & $220 \cdot 42$ & $220 \cdot 23$ & 220.03 & 219.84 & 219.65 & 219.46 & 219.27 & 219.07 & -2.90 \\
\hline-2.80 & 222.90 & 222.71 & 222.52 & 222.33 & $222 \cdot 14$ & 221.95 & 221.76 & 221.56 & 221.37 & $221 \cdot 18$ & 220.99 & -2.80 \\
\hline$-2 \cdot 70$ & 224.80 & 224.61 & $224 \cdot 42$ & 224.23 & 224.04 & 223.85 & $223 \cdot 66$ & 223.47 & 223.28 & 223.09 & 222.90 & $-2 \cdot 70$ \\
\hline$-2 \cdot 60$ & 226.69 & 226.50 & $226 \cdot 31$ & 226.12 & 225.93 & 225.74 & 225.55 & 225.37 & 225.18 & 224.99 & $224 \cdot 80$ & -2.60 \\
\hline-2.50 & $228 \cdot 57$ & $228 \cdot 38$ & $228 \cdot 19$ & 228.00 & 227.82 & 227.63 & 227.44 & 227.25 & 227.06 & 226.88 & 226.69 & -2.50 \\
\hline-2.40 & 230.44 & 230.25 & 230.07 & 229.88 & 229.69 & 229.51 & $229 \cdot 32$ & 229.13 & $228 \cdot 94$ & 228.76 & 228.57 & -2.40 \\
\hline$-2 \cdot 30$ & 232.30 & 232.12 & 231.93 & 231.75 & 231.56 & 231.37 & $231 \cdot 19$ & 231.00 & 230.81 & 230.63 & 230.44 & $-2 \cdot 30$ \\
\hline$-2 \cdot 20$ & 234.16 & 233.97 & 233.79 & 233.60 & $233 \cdot 42$ & 233.23 & 233.05 & 232.86 & 232.68 & 232.49 & 232.30 & -2.20 \\
\hline$-2 \cdot 10$ & 236.01 & 235.82 & 235.64 & 235.45 & 235.27 & 235.08 & 234.90 & 234.71 & 234.53 & $234 \cdot 34$ & $234 \cdot 16$ & -2.10 \\
\hline$-2 \cdot 00$ & 237.84 & 237.66 & 237.48 & 237.29 & $237 \cdot 11$ & 236.93 & 236.74 & 236.56 & 236.37 & 236.19 & 236.01 & -2.00 \\
\hline$-1 \cdot 90$ & 239.68 & 239.49 & 239.31 & 239.13 & $238 \cdot 94$ & 238.76 & 238.58 & $238 \cdot 40$ & 238.21 & 238.03 & 237.84 & -1.90 \\
\hline-1.80 & 241.50 & 241.32 & 241.14 & 240.95 & 240.77 & 240.59 & 240.41 & 240.22 & 240.04 & 239.86 & 239.68 & -1.80 \\
\hline$-1 \cdot 70$ & 243.32 & 243.13 & 242.95 & 242.77 & 242.59 & 242.41 & 242.23 & 242.05 & 241.86 & 241.68 & 241.50 & -1.70 \\
\hline-1.60 & 245.12 & $244 \cdot 94$ & $244 \cdot 76$ & 244.58 & $244 \cdot 40$ & 244.22 & 244.04 & 243.86 & 243.68 & 243.50 & 243.32 & -1.60 \\
\hline$-1 \cdot 50$ & 246.93 & 246.75 & 246.57 & 246.39 & $246 \cdot 21$ & 246.03 & 245.85 & 245.67 & 245.48 & 245.30 & $245 \cdot 12$ & -1.50 \\
\hline-1.40 & $248 \cdot 72$ & 248.54 & $248 \cdot 36$ & 248.18 & 248.00 & 247.82 & 247.64 & 247.46 & 247.28 & 247.10 & 246.93 & -1.40 \\
\hline$-1 \cdot 30$ & 250.51 & 250.33 & $250 \cdot 15$ & 249.97 & 249.79 & 249.61 & $249 \cdot 43$ & 249.26 & 249.08 & 248.90 & 248.72 & $-1 \cdot 30$ \\
\hline$-1 \cdot 20$ & 252.29 & 252.11 & 251.93 & 251.75 & 251.58 & 251.40 & 251.22 & 251.04 & 250.86 & 250.68 & 250.51 & -1.20 \\
\hline$-1 \cdot 10$ & 254.06 & 253.88 & 253.71 & 253.53 & 253.35 & 253.17 & 253.00 & 252.82 & 252.64 & 252.46 & 252.29 & $-1 \cdot 10$ \\
\hline-1.00 & 255.83 & 255.65 & 255.47 & 255.30 & $255 \cdot 12$ & 254.94 & $254 \cdot 77$ & 254.59 & 254.41 & 254.24 & 254.06 & -1.00 \\
\hline-0.90 & 257.59 & 257.41 & 257.23 & 257.06 & 256.88 & 256.71 & 256.53 & 256.36 & $256 \cdot 18$ & 256.00 & 255.83 & -0.90 \\
\hline-0.80 & 259.34 & $259 \cdot 16$ & 258.99 & 258.81 & 258.64 & $258 \cdot 46$ & $258 \cdot 29$ & 258.11 & 257.94 & $257 \cdot 76$ & 257.59 & -0.80 \\
\hline-0.70 & 261.09 & 260.91 & 260.74 & 260.56 & 260.39 & 260.21 & 260.04 & 259.86 & 259.69 & 259.51 & 259.34 & -0.70 \\
\hline-0.60 & 262.83 & 262.65 & $262 \cdot 48$ & 262.31 & 262.13 & 261.96 & 261.78 & 261.61 & $261 \cdot 44$ & 261.26 & 261.09 & -0.60 \\
\hline-0.50 & $264 \cdot 56$ & $264 \cdot 39$ & $264 \cdot 22$ & 264.04 & 263.87 & 263.70 & 263.52 & 263.35 & $263 \cdot 18$ & 263.00 & 262.83 & -0.50 \\
\hline-0.40 & 266.29 & $266 \cdot 12$ & 265.95 & 265.77 & 265.60 & 265.43 & 265.26 & 265.08 & 264.91 & 264.74 & $264 \cdot 56$ & -0.40 \\
\hline$-0 \cdot 30$ & 268.01 & 267.84 & 267.67 & 267.50 & 267.33 & 267.15 & 266.98 & 266.81 & 266.64 & 266.46 & 266.29 & -0.30 \\
\hline-0.20 & 269.73 & 269.56 & 269.39 & 269.22 & 269.05 & 268.87 & 268.70 & 268.53 & $268 \cdot 36$ & $268 \cdot 19$ & 268.01 & -0.20 \\
\hline-0.10 & 271.44 & 271.27 & 271.10 & 270.93 & 270.76 & 270.59 & $270 \cdot 42$ & 270.25 & 270.07 & 269.90 & 269.73 & -0.10 \\
\hline 0.00 & 273.15 & 272.98 & $272 \cdot 81$ & 272.64 & 272.47 & $272 \cdot 30$ & $272 \cdot 13$ & 271.96 & 271.79 & 271.61 & 271.44 & 0.00 \\
\hline
\end{tabular}

\begin{abstract}
154.74
\end{abstract}
.00

.01

.02
.03 
.04

.05

.06

.07

.08

.09

.10

TEMPERATURES IN K

\begin{tabular}{|c|c|c|c|c|c|c|c|c|c|c|c|c|}
\hline $\begin{array}{l}-6 \cdot 40 \\
-6 \cdot 30 \\
-6 \cdot 20 \\
-6 \cdot 10 \\
-6 \cdot 00\end{array}$ & $\begin{array}{l}23.90 \\
38.83 \\
49.37 \\
58.07 \\
65.69\end{array}$ & $\begin{array}{l}21.81 \\
37.62 \\
48.42 \\
57.26 \\
64.97\end{array}$ & $\begin{array}{l}19.48 \\
36.36 \\
47.45 \\
56.44 \\
64.24\end{array}$ & $\begin{array}{l}16.80 \\
35.06 \\
46.46 \\
55.60 \\
63.49\end{array}$ & $\begin{array}{l}13.57 \\
33.70 \\
45.45 \\
54.75 \\
62.75\end{array}$ & $\begin{array}{r}9.23 \\
32.28 \\
44.42 \\
53.89 \\
61.99\end{array}$ & $\begin{array}{l}30.80 \\
43.36 \\
53.02 \\
61.23\end{array}$ & $\begin{array}{l}29.23 \\
42.27 \\
52.13 \\
60.45\end{array}$ & $\begin{array}{l}27.58 \\
41.16 \\
51.23 \\
59.67\end{array}$ & $\begin{array}{l}25.81 \\
40.01 \\
50.31 \\
58.88\end{array}$ & $\begin{array}{l}23.90 \\
38.83 \\
49.37 \\
58.07\end{array}$ & $\begin{array}{l}-6.40 \\
-6.30 \\
-6.20 \\
-6.10 \\
-6.00\end{array}$ \\
\hline $\begin{array}{l}-5.90 \\
-5.80 \\
-5.70 \\
-5.60 \\
-5.50\end{array}$ & $\begin{array}{l}72.58 \\
78.93 \\
84.87 \\
90.47 \\
95.79\end{array}$ & $\begin{array}{l}71.92 \\
78.32 \\
84.29 \\
89.92 \\
95.27\end{array}$ & $\begin{array}{l}71.25 \\
77.70 \\
83.71 \\
89.37 \\
94.75\end{array}$ & $\begin{array}{l}70.58 \\
77.08 \\
83.13 \\
88.82 \\
94.22\end{array}$ & $\begin{array}{l}69.90 \\
76.45 \\
82.54 \\
88.27 \\
93.69\end{array}$ & $\begin{array}{l}69.21 \\
75.82 \\
81.95 \\
87.71 \\
93.16\end{array}$ & $\begin{array}{l}68.52 \\
75.18 \\
81.35 \\
87.15 \\
92.63\end{array}$ & $\begin{array}{l}67.83 \\
74.54 \\
80.75 \\
86.58 \\
92.09\end{array}$ & $\begin{array}{l}67.12 \\
73.89 \\
80.15 \\
86.01 \\
91.55\end{array}$ & $\begin{array}{l}66.41 \\
73.24 \\
79.55 \\
85.44 \\
91.01\end{array}$ & $\begin{array}{l}65.69 \\
72.58 \\
78.93 \\
84.87 \\
90.47\end{array}$ & $\begin{array}{l}-5.90 \\
-5.80 \\
-5.70 \\
-5.60 \\
-5.50\end{array}$ \\
\hline $\begin{array}{l}-5 \cdot 40 \\
-5 \cdot 30 \\
-5 \cdot 20 \\
-5 \cdot 10 \\
-5 \cdot 00\end{array}$ & $\begin{array}{l}100.87 \\
105.75 \\
110.45 \\
115.00 \\
119.40\end{array}$ & $\begin{array}{l}100.37 \\
105.27 \\
109.99 \\
114.55 \\
118.97\end{array}$ & $\begin{array}{r}99.87 \\
104.79 \\
109.53 \\
114.10 \\
118.53\end{array}$ & $\begin{array}{r}99.37 \\
104.31 \\
109.06 \\
113.65 \\
118.09\end{array}$ & $\begin{array}{r}98.87 \\
103.82 \\
108.59 \\
113.20 \\
117.65\end{array}$ & $\begin{array}{r}98.36 \\
103.34 \\
108.12 \\
112.74 \\
117.21\end{array}$ & $\begin{array}{r}97.85 \\
102.85 \\
107.65 \\
112.29 \\
116.77\end{array}$ & $\begin{array}{r}97.34 \\
102.36 \\
107.18 \\
111.83 \\
116.33\end{array}$ & $\begin{array}{r}96.82 \\
101.86 \\
106.71 \\
111.37 \\
115.89\end{array}$ & $\begin{array}{r}96.31 \\
101.37 \\
106.23 \\
110.91 \\
115.44\end{array}$ & $\begin{array}{r}95.79 \\
100.87 \\
105.75 \\
110.45 \\
115.00\end{array}$ & $\begin{array}{l}-5.40 \\
-5.30 \\
-5.20 \\
-5.10 \\
-5.00\end{array}$ \\
\hline $\begin{array}{l}-4.90 \\
-4.80 \\
-4.70 \\
-4.60 \\
-4.50\end{array}$ & $\begin{array}{l}123.68 \\
127.84 \\
131.90 \\
135.86 \\
139.74\end{array}$ & $\begin{array}{l}123.25 \\
127.43 \\
131.50 \\
135.47 \\
139.36\end{array}$ & $\begin{array}{l}122.83 \\
127.02 \\
131.10 \\
135.08 \\
138.97\end{array}$ & $\begin{array}{l}122.41 \\
126.60 \\
130.69 \\
134.68 \\
138.59\end{array}$ & $\begin{array}{l}121.98 \\
126 \cdot 19 \\
130.29 \\
134.29 \\
138.20\end{array}$ & $\begin{array}{l}121.55 \\
125.77 \\
129.88 \\
133.89 \\
137.81\end{array}$ & $\begin{array}{l}121.13 \\
125.36 \\
129.48 \\
133.50 \\
137.42\end{array}$ & $\begin{array}{l}120.70 \\
124.94 \\
129.07 \\
133.10 \\
137.04\end{array}$ & $\begin{array}{l}120.27 \\
124.52 \\
128.66 \\
132.70 \\
136.65\end{array}$ & $\begin{array}{l}119.83 \\
124.10 \\
128.25 \\
132.30 \\
136.26\end{array}$ & $\begin{array}{l}119.40 \\
123.68 \\
127.84 \\
131.90 \\
135.86\end{array}$ & $\begin{array}{l}-4.90 \\
-4.80 \\
-4.70 \\
-4.60 \\
-4.50\end{array}$ \\
\hline $\begin{array}{l}-4 \cdot 40 \\
-4 \cdot 30 \\
-4 \cdot 20 \\
-4 \cdot 10 \\
-4 \cdot 00\end{array}$ & $\begin{array}{l}143.54 \\
147.26 \\
150.91 \\
154.50 \\
158.03\end{array}$ & $\begin{array}{l}143.16 \\
146.89 \\
150.55 \\
154.14 \\
157.68\end{array}$ & $\begin{array}{l}142.78 \\
146.52 \\
150.19 \\
153.79 \\
157.33\end{array}$ & $\begin{array}{l}142.41 \\
145.15 \\
149.82 \\
153.43 \\
156.98\end{array}$ & $\begin{array}{l}142.03 \\
145.78 \\
149.46 \\
153.07 \\
156.62\end{array}$ & $\begin{array}{l}141.65 \\
145.41 \\
149.09 \\
152.71 \\
156.27\end{array}$ & $\begin{array}{l}141.27 \\
145.04 \\
148.73 \\
152.36 \\
155.92\end{array}$ & $\begin{array}{l}140.89 \\
144.66 \\
148.36 \\
152.00 \\
155.57\end{array}$ & $\begin{array}{l}140.51 \\
144.29 \\
148.00 \\
151.64 \\
155.21\end{array}$ & $\begin{array}{l}140.12 \\
143.91 \\
147.63 \\
151.27 \\
154.86\end{array}$ & $\begin{array}{l}139.74 \\
143.54 \\
147.26 \\
150.91 \\
154.50\end{array}$ & $\begin{array}{l}-4.40 \\
-4.30 \\
-4.20 \\
-4.10 \\
-4.00\end{array}$ \\
\hline $\begin{array}{l}-3.90 \\
-3.80 \\
-3.70 \\
-3.60 \\
-3.50\end{array}$ & $\begin{array}{l}161.50 \\
164.92 \\
168.29 \\
171.61 \\
174.89\end{array}$ & $\begin{array}{l}161.16 \\
164.58 \\
167.95 \\
171.28 \\
174.56\end{array}$ & $\begin{array}{l}160.81 \\
164.24 \\
167.62 \\
170.95 \\
174.24\end{array}$ & $\begin{array}{l}160.47 \\
163.90 \\
167.28 \\
170.62 \\
173.91\end{array}$ & $\begin{array}{l}160.12 \\
163.56 \\
166.95 \\
170.29 \\
173.58\end{array}$ & $\begin{array}{l}159.77 \\
163.22 \\
166.61 \\
169.96 \\
173.26\end{array}$ & $\begin{array}{l}159.42 \\
162.87 \\
166.27 \\
169.62 \\
172.93\end{array}$ & $\begin{array}{l}159.08 \\
162.53 \\
165.94 \\
169.29 \\
172.60\end{array}$ & $\begin{array}{l}158.73 \\
162.19 \\
165.60 \\
168.96 \\
172.27\end{array}$ & $\begin{array}{l}158.38 \\
161.85 \\
165.26 \\
168.62 \\
171.94\end{array}$ & $\begin{array}{l}158.03 \\
161.50 \\
164.92 \\
168.29 \\
171.61\end{array}$ & $\begin{array}{l}-3.90 \\
-3.80 \\
-3.70 \\
-3.60 \\
-3.50\end{array}$ \\
\hline $\begin{array}{l}-3 \cdot 40 \\
-3 \cdot 30 \\
-3 \cdot 20 \\
-3 \cdot 10 \\
-3 \cdot 00\end{array}$ & $\begin{array}{l}178.13 \\
181.32 \\
184.48 \\
187.61 \\
190.69\end{array}$ & $\begin{array}{l}177.80 \\
181.00 \\
184.17 \\
187.29 \\
190.39\end{array}$ & $\begin{array}{l}177.48 \\
180.69 \\
183.85 \\
186.98 \\
190.08\end{array}$ & $\begin{array}{l}177.16 \\
180.37 \\
183.54 \\
186.67 \\
189.77\end{array}$ & $\begin{array}{l}176.84 \\
180.05 \\
183.22 \\
186.36 \\
189.46\end{array}$ & $\begin{array}{l}176.51 \\
179.73 \\
182.91 \\
186.05 \\
189.15\end{array}$ & $\begin{array}{l}176.19 \\
179.41 \\
182.59 \\
185.74 \\
188.84\end{array}$ & $\begin{array}{l}175.86 \\
179.09 \\
182.27 \\
185.42 \\
188.54\end{array}$ & $\begin{array}{l}175.54 \\
178.77 \\
181.96 \\
185.11 \\
188.23\end{array}$ & $\begin{array}{l}175.22 \\
178.45 \\
181.64 \\
184.80 \\
187.92\end{array}$ & $\begin{array}{l}174 \cdot 89 \\
178 \cdot 13 \\
181 \cdot 32 \\
184 \cdot 48 \\
187 \cdot 61\end{array}$ & $\begin{array}{l}-3.40 \\
-3.30 \\
-3.20 \\
-3.10 \\
-3.00\end{array}$ \\
\hline $\begin{array}{l}-2.90 \\
-2.80 \\
-2.70 \\
-2.60 \\
-2.50\end{array}$ & $\begin{array}{l}193.75 \\
196.78 \\
199.78 \\
202.75 \\
205.69\end{array}$ & $\begin{array}{l}193.45 \\
196.48 \\
199.48 \\
202.45 \\
205.39\end{array}$ & $\begin{array}{l}193 \cdot 14 \\
196 \cdot 18 \\
199 \cdot 18 \\
202 \cdot 15 \\
205 \cdot 10\end{array}$ & $\begin{array}{l}192.84 \\
195.87 \\
198.88 \\
201.86 \\
204.81\end{array}$ & $\begin{array}{l}192.53 \\
195.57 \\
198.58 \\
201.56 \\
204.51\end{array}$ & $\begin{array}{l}192.23 \\
195.27 \\
198.28 \\
201.26 \\
204.22\end{array}$ & $\begin{array}{l}191.92 \\
194.97 \\
197.98 \\
200.97 \\
203.93\end{array}$ & $\begin{array}{l}191.62 \\
194.66 \\
197.68 \\
200.67 \\
203.63\end{array}$ & $\begin{array}{l}191 \cdot 31 \\
194 \cdot 36 \\
197 \cdot 38 \\
200 \cdot 37 \\
203 \cdot 34\end{array}$ & $\begin{array}{l}191.00 \\
194.06 \\
197.08 \\
200.07 \\
203.04\end{array}$ & $\begin{array}{l}190.69 \\
193.75 \\
196.78 \\
199.78 \\
202.75\end{array}$ & $\begin{array}{l}-2.90 \\
-2.80 \\
-2.70 \\
-2.60 \\
-2.50\end{array}$ \\
\hline $\begin{array}{l}-2 \cdot 40 \\
-2 \cdot 30 \\
-2 \cdot 20 \\
-2 \cdot 10 \\
-2 \cdot 00\end{array}$ & $\begin{array}{l}208.60 \\
211.50 \\
214.37 \\
217.21 \\
220.04\end{array}$ & $\begin{array}{l}208.31 \\
211.21 \\
214.08 \\
216.93 \\
219.76\end{array}$ & $\begin{array}{l}208.02 \\
210.92 \\
213.80 \\
216.65 \\
219.48\end{array}$ & $\begin{array}{l}207.73 \\
210.63 \\
213.51 \\
216.36 \\
219.19\end{array}$ & $\begin{array}{l}207 \cdot 44 \\
210 \cdot 34 \\
213 \cdot 22 \\
216.08 \\
218.91\end{array}$ & $\begin{array}{l}207.15 \\
210.05 \\
212.94 \\
215.79 \\
218.63\end{array}$ & $\begin{array}{l}206.86 \\
209 \cdot 76 \\
212.65 \\
215.51 \\
218 \cdot 35\end{array}$ & $\begin{array}{l}206.57 \\
209.48 \\
212.36 \\
215.22 \\
218.06\end{array}$ & $\begin{array}{l}206.27 \\
209.19 \\
212.07 \\
214.94 \\
217.78\end{array}$ & $\begin{array}{l}205.98 \\
208.90 \\
211.79 \\
214.65 \\
217.50\end{array}$ & $\begin{array}{l}205.69 \\
208.60 \\
211.50 \\
214.37 \\
217.21\end{array}$ & $\begin{array}{l}-2.40 \\
-2.30 \\
-2.20 \\
-2.10 \\
-2.00\end{array}$ \\
\hline $\begin{array}{l}-1 \cdot 90 \\
-1.80 \\
-1.70 \\
-1.60 \\
-1.50\end{array}$ & $\begin{array}{l}222 \cdot 84 \\
225.63 \\
228.40 \\
231.14 \\
233.88\end{array}$ & $\begin{array}{l}222.57 \\
225.35 \\
228.12 \\
230.87 \\
233.60\end{array}$ & $\begin{array}{l}222 \cdot 29 \\
225.07 \\
227.84 \\
230.60 \\
233.33\end{array}$ & $\begin{array}{l}222.01 \\
224.80 \\
227.57 \\
230.32 \\
233.06\end{array}$ & $\begin{array}{l}221.73 \\
224.52 \\
227.29 \\
230.05 \\
232.79\end{array}$ & $\begin{array}{l}221.44 \\
224.24 \\
227.02 \\
229.77 \\
232.51\end{array}$ & $\begin{array}{l}221.16 \\
223.96 \\
226.74 \\
229.50 \\
232.24\end{array}$ & $\begin{array}{l}220.88 \\
223.68 \\
226.46 \\
229.22 \\
231.97\end{array}$ & $\begin{array}{l}220.60 \\
223.40 \\
226.18 \\
228.95 \\
231.69\end{array}$ & $\begin{array}{l}220.32 \\
223.12 \\
225.91 \\
228.67 \\
231.42\end{array}$ & $\begin{array}{l}220.04 \\
222.84 \\
225.63 \\
228.40 \\
231 \cdot 14\end{array}$ & $\begin{array}{l}-1.90 \\
-1.80 \\
-1.70 \\
-1.60 \\
-1.50\end{array}$ \\
\hline $\begin{array}{l}-1.40 \\
-1 \cdot 30 \\
-1.20 \\
-1.10 \\
-1.00\end{array}$ & $\begin{array}{l}236.59 \\
239.29 \\
241.97 \\
244.64 \\
247.29\end{array}$ & $\begin{array}{l}236.32 \\
239.02 \\
241.70 \\
244.37 \\
247.03\end{array}$ & $\begin{array}{l}236.05 \\
238 \cdot 75 \\
241.44 \\
244.11 \\
246.76\end{array}$ & $\begin{array}{l}235.78 \\
238.48 \\
241.17 \\
243.84 \\
246.50\end{array}$ & $\begin{array}{l}235.51 \\
238.21 \\
240.90 \\
243.57 \\
246.23\end{array}$ & $\begin{array}{l}235.23 \\
237.94 \\
240.63 \\
243.31 \\
245.97\end{array}$ & $\begin{array}{l}234.96 \\
237.67 \\
240.36 \\
243.04 \\
245.70\end{array}$ & $\begin{array}{l}234.69 \\
237.40 \\
240.09 \\
242.77 \\
245.44\end{array}$ & $\begin{array}{l}234.42 \\
237.13 \\
239.83 \\
242.51 \\
245.17\end{array}$ & $\begin{array}{l}234.15 \\
236.86 \\
239.56 \\
242.24 \\
244.90\end{array}$ & $\begin{array}{l}233.88 \\
236.59 \\
239.29 \\
241.97 \\
244.64\end{array}$ & $\begin{array}{l}-1.40 \\
-1.30 \\
-1.20 \\
-1.10 \\
-1.00\end{array}$ \\
\hline $\begin{array}{l}-0.90 \\
-0.80 \\
-0.70\end{array}$ & $\begin{array}{l}249.93 \\
252.56 \\
255.17\end{array}$ & $\begin{array}{l}249.67 \\
252.30 \\
254.91\end{array}$ & $\begin{array}{l}249.40 \\
252.03 \\
254.65\end{array}$ & $\begin{array}{l}249.14 \\
251.77 \\
254.39\end{array}$ & $\begin{array}{l}248.88 \\
251.51 \\
254.13\end{array}$ & $\begin{array}{l}248.61 \\
251.25 \\
253.87\end{array}$ & $\begin{array}{l}248.35 \\
250.98 \\
253.60\end{array}$ & $\begin{array}{l}248.08 \\
250.72 \\
253.34\end{array}$ & $\begin{array}{l}247.82 \\
250.46 \\
253.08\end{array}$ & $\begin{array}{l}247.56 \\
250.19 \\
252.82\end{array}$ & $\begin{array}{l}247.29 \\
249.93 \\
252.56\end{array}$ & $\begin{array}{l}-0.90 \\
-0.80 \\
-0.70\end{array}$ \\
\hline $\begin{array}{l}-0.60 \\
-0.50\end{array}$ & $\begin{array}{l}257.77 \\
260.36\end{array}$ & $\begin{array}{l}257.51 \\
260.10\end{array}$ & $\begin{array}{l}257.25 \\
259.85\end{array}$ & $\begin{array}{l}256.99 \\
259.59\end{array}$ & $\begin{array}{l}256.73 \\
259.33\end{array}$ & $\begin{array}{l}256.47 \\
259.07\end{array}$ & $\begin{array}{l}256.21 \\
258.81\end{array}$ & $\begin{array}{l}255.95 \\
258.55\end{array}$ & $\begin{array}{l}255.69 \\
258.29\end{array}$ & $\begin{array}{l}255.43 \\
258.03\end{array}$ & $\begin{array}{l}255.17 \\
257.77\end{array}$ & $\begin{array}{l}-0.60 \\
-0.50\end{array}$ \\
\hline $\begin{array}{r}-0.40 \\
-0.30 \\
-0.20 \\
-0.10 \\
0.00\end{array}$ & $\begin{array}{l}262.94 \\
265.51 \\
268.07 \\
270.61 \\
273.15\end{array}$ & $\begin{array}{l}262.68 \\
265 \cdot 25 \\
267.81 \\
270.36 \\
272.90\end{array}$ & $\begin{array}{l}262.43 \\
265.00 \\
267.55 \\
270.10 \\
272.64\end{array}$ & $\begin{array}{l}262.17 \\
264.74 \\
267.30 \\
269.85 \\
272.39\end{array}$ & $\begin{array}{l}261.91 \\
264.48 \\
267.04 \\
269.59 \\
272.14\end{array}$ & $\begin{array}{l}261.65 \\
264 \cdot 23 \\
266.79 \\
269.34 \\
271.88\end{array}$ & $\begin{array}{l}261.39 \\
263.97 \\
266.53 \\
269.09 \\
271.63\end{array}$ & $\begin{array}{l}261.14 \\
263.71 \\
266.28 \\
268.83 \\
271.37\end{array}$ & $\begin{array}{l}260.88 \\
263.45 \\
266.02 \\
268.58 \\
271.12\end{array}$ & $\begin{array}{l}260.62 \\
263.20 \\
265.76 \\
268.32 \\
270.87\end{array}$ & $\begin{array}{l}260.36 \\
262.94 \\
265.51 \\
268.07 \\
270.61\end{array}$ & $\begin{array}{r}-0.40 \\
-0.30 \\
-0.20 \\
-0.10 \\
0.00\end{array}$ \\
\hline
\end{tabular}


$\mathrm{mV}$

.00

.01

.02

.03

.04

.05

.06

.07

TEMPERATURES IN K

\begin{tabular}{|c|c|c|c|c|c|c|c|c|c|c|c|c|}
\hline $\begin{array}{l}-6.20 \\
-6.10 \\
-6.00\end{array}$ & $\begin{array}{l}19.87 \\
33.73 \\
43.77\end{array}$ & $\begin{array}{l}17.99 \\
32.58 \\
42.85\end{array}$ & $\begin{array}{l}15 \cdot 93 \\
31.40 \\
41.92\end{array}$ & $\begin{array}{l}13.61 \\
30.18 \\
40.97\end{array}$ & $\begin{array}{l}10.90 \\
28.91 \\
40.01\end{array}$ & $\begin{array}{r}7.46 \\
27.59 \\
39.02\end{array}$ & $\begin{array}{l}26.21 \\
38.01\end{array}$ & $\begin{array}{l}24.76 \\
36.98\end{array}$ & $\begin{array}{l}23.23 \\
35.92\end{array}$ & $\begin{array}{l}21.61 \\
34.84\end{array}$ & $\begin{array}{l}19.87 \\
33.73\end{array}$ & $\begin{array}{l}-6.20 \\
-6.10 \\
-6.00\end{array}$ \\
\hline $\begin{array}{l}-5.90 \\
-5.80 \\
-5.70 \\
-5.60 \\
-5.50\end{array}$ & $\begin{array}{l}52.24 \\
59.82 \\
66.80 \\
73.34 \\
79.51\end{array}$ & $\begin{array}{l}51.44 \\
59.10 \\
66.13 \\
72.70 \\
78.91\end{array}$ & $\begin{array}{l}50.63 \\
58.36 \\
65.45 \\
72.06 \\
78.30\end{array}$ & $\begin{array}{l}49.82 \\
57.62 \\
64.76 \\
71.42 \\
77.69\end{array}$ & $\begin{array}{l}48.99 \\
56.88 \\
64.07 \\
70.77 \\
77.08\end{array}$ & $\begin{array}{l}48.15 \\
56.12 \\
63.38 \\
70.12 \\
76.46\end{array}$ & $\begin{array}{l}47.30 \\
55.36 \\
62.68 \\
69.46 \\
75.84\end{array}$ & $\begin{array}{l}46.43 \\
54.59 \\
61.97 \\
68.81 \\
75.22\end{array}$ & $\begin{array}{l}45.56 \\
53.82 \\
61.26 \\
68.14 \\
74.60\end{array}$ & $\begin{array}{l}44.67 \\
53.04 \\
60.55 \\
67.47 \\
73.97\end{array}$ & $\begin{array}{l}43.77 \\
52.24 \\
59.82 \\
66.80 \\
73.34\end{array}$ & $\begin{array}{l}-5.90 \\
-5.80 \\
-5.70 \\
-5.60 \\
-5.50\end{array}$ \\
\hline $\begin{array}{l}-5.40 \\
-5.30 \\
-5.20 \\
-5.10 \\
-5.00\end{array}$ & $\begin{array}{r}85.38 \\
91.00 \\
96.40 \\
101.60 \\
106.62\end{array}$ & $\begin{array}{r}84.81 \\
90.45 \\
95.87 \\
101.08 \\
106.13\end{array}$ & $\begin{array}{r}84.23 \\
89.90 \\
95.33 \\
100.57 \\
105.63\end{array}$ & $\begin{array}{r}83.65 \\
89.34 \\
94.80 \\
100.05 \\
105.13\end{array}$ & $\begin{array}{r}83.07 \\
88.78 \\
94.26 \\
99.54 \\
104.63\end{array}$ & $\begin{array}{r}82.48 \\
88.22 \\
93.72 \\
99.02 \\
104.13\end{array}$ & $\begin{array}{r}81.89 \\
87.66 \\
93.18 \\
98.50 \\
103.63\end{array}$ & $\begin{array}{r}81.30 \\
87.09 \\
92.64 \\
97.98 \\
103.12\end{array}$ & $\begin{array}{r}80.71 \\
86.53 \\
92.10 \\
97.45 \\
102.61\end{array}$ & $\begin{array}{r}80.11 \\
85.95 \\
91.55 \\
96.92 \\
102.11\end{array}$ & $\begin{array}{r}79.51 \\
85.38 \\
91.00 \\
96.40 \\
101.60\end{array}$ & $\begin{array}{l}-5.40 \\
-5.30 \\
-5.20 \\
-5.10 \\
-5.00\end{array}$ \\
\hline $\begin{array}{l}-4 \cdot 90 \\
-4 \cdot 80 \\
-4 \cdot 70 \\
-4 \cdot 60 \\
-4 \cdot 50\end{array}$ & $\begin{array}{l}111.49 \\
116.22 \\
120.82 \\
125.30 \\
129.67\end{array}$ & $\begin{array}{l}111.01 \\
115.75 \\
120.36 \\
124.85 \\
129.24\end{array}$ & $\begin{array}{l}110.53 \\
115.28 \\
119.91 \\
124.41 \\
128.80\end{array}$ & $\begin{array}{l}110.04 \\
114.81 \\
119.45 \\
123.96 \\
128.37\end{array}$ & $\begin{array}{l}109.56 \\
114.34 \\
118.99 \\
123.52 \\
127.93\end{array}$ & $\begin{array}{l}109.07 \\
113.87 \\
118.53 \\
123.07 \\
127.50\end{array}$ & $\begin{array}{l}108.59 \\
113.40 \\
118.07 \\
122.62 \\
127.06\end{array}$ & $\begin{array}{l}108.10 \\
112.92 \\
117.61 \\
122.17 \\
126.62\end{array}$ & $\begin{array}{l}107.61 \\
112.45 \\
117.15 \\
121.72 \\
126.18\end{array}$ & $\begin{array}{l}107.11 \\
111.97 \\
116.68 \\
121.27 \\
125.74\end{array}$ & $\begin{array}{l}106.62 \\
111.49 \\
116.22 \\
120.82 \\
125.30\end{array}$ & $\begin{array}{l}-4.90 \\
-4.80 \\
-4.70 \\
-4.60 \\
-4.50\end{array}$ \\
\hline $\begin{array}{l}-4.40 \\
-4.30 \\
-4.20 \\
-4.10 \\
-4.00\end{array}$ & $\begin{array}{l}133.94 \\
138.12 \\
142.21 \\
146.22 \\
150.16\end{array}$ & $\begin{array}{l}133.52 \\
137.71 \\
141.81 \\
145.83 \\
149.77\end{array}$ & $\begin{array}{l}133.10 \\
137.29 \\
141.40 \\
145.43 \\
149.38\end{array}$ & $\begin{array}{l}132.67 \\
136.88 \\
140.99 \\
145.03 \\
148.98\end{array}$ & $\begin{array}{l}132.25 \\
136.46 \\
140.59 \\
144.63 \\
148.59\end{array}$ & $\begin{array}{l}131.82 \\
136.04 \\
140.18 \\
144.23 \\
148.20\end{array}$ & $\begin{array}{l}131.39 \\
135.62 \\
139.77 \\
143.83 \\
147.81\end{array}$ & $\begin{array}{r}130.96 \\
.135 .21 \\
139.36 \\
143.42 \\
147.41\end{array}$ & $\begin{array}{l}130.53 \\
134.79 \\
138.95 \\
143.02 \\
147.02\end{array}$ & $\begin{array}{l}130.10 \\
134.36 \\
138.53 \\
142.62 \\
146.62\end{array}$ & $\begin{array}{l}129.67 \\
133.94 \\
138.12 \\
142.21 \\
146.22\end{array}$ & $\begin{array}{l}-4 \cdot 40 \\
-4.30 \\
-4.20 \\
-4.10 \\
-4.00\end{array}$ \\
\hline $\begin{array}{l}-3.90 \\
-3.80 \\
-3.70 \\
-3.60 \\
-3.50\end{array}$ & $\begin{array}{l}154.02 \\
157.81 \\
161.54 \\
165.21 \\
168.82\end{array}$ & $\begin{array}{l}153.63 \\
157.43 \\
161.17 \\
164.85 \\
168.46\end{array}$ & $\begin{array}{l}153.25 \\
157.06 \\
160.80 \\
164.48 \\
168.11\end{array}$ & $\begin{array}{l}152.87 \\
156.68 \\
160.43 \\
164.12 \\
167.75\end{array}$ & $\begin{array}{l}152.48 \\
156.30 \\
160.06 \\
163.75 \\
167.39\end{array}$ & $\begin{array}{l}152.10 \\
155.92 \\
159.68 \\
163.38 \\
167.02\end{array}$ & $\begin{array}{l}151.71 \\
155.54 \\
159.31 \\
163.02 \\
166.66\end{array}$ & $\begin{array}{l}151.32 \\
155.16 \\
158.94 \\
162.65 \\
166.30\end{array}$ & $\begin{array}{l}150.93 \\
154.78 \\
158.56 \\
162.28 \\
165.94\end{array}$ & $\begin{array}{l}150.55 \\
154.40 \\
158.19 \\
161.91 \\
165.57\end{array}$ & $\begin{array}{l}150.16 \\
154.02 \\
157.81 \\
161.54 \\
165.21\end{array}$ & $\begin{array}{l}-3.90 \\
-3.80 \\
-3.70 \\
-3.60 \\
-3.50\end{array}$ \\
\hline $\begin{array}{l}-3.40 \\
-3.30 \\
-3.20 \\
-3.10 \\
-3.00\end{array}$ & $\begin{array}{l}172.38 \\
175.89 \\
179.35 \\
182.76 \\
186.13\end{array}$ & $\begin{array}{l}172.03 \\
175.54 \\
179.01 \\
182.42 \\
185.80\end{array}$ & $\begin{array}{l}171.67 \\
175.19 \\
178.66 \\
182.08 \\
185.46\end{array}$ & $\begin{array}{l}171.32 \\
174.84 \\
178.32 \\
181.74 \\
185.13\end{array}$ & $\begin{array}{l}170.97 \\
174.49 \\
177.97 \\
181.40 \\
184.79\end{array}$ & $\begin{array}{l}170.61 \\
174.14 \\
177.63 \\
181.06 \\
184.45\end{array}$ & $\begin{array}{l}170.25 \\
173 \cdot 79 \\
177.28 \\
180.72 \\
184.12\end{array}$ & $\begin{array}{l}169.90 \\
173.44 \\
176.93 \\
180.38 \\
183.78\end{array}$ & $\begin{array}{l}169.54 \\
173.09 \\
176.59 \\
180.04 \\
183.44\end{array}$ & $\begin{array}{l}169.18 \\
172.74 \\
176.24 \\
179.69 \\
183.10\end{array}$ & $\begin{array}{l}168.82 \\
172.38 \\
175.89 \\
179.35 \\
182.76\end{array}$ & $\begin{array}{l}-3.40 \\
-3.30 \\
-3.20 \\
-3.10 \\
-3.00\end{array}$ \\
\hline $\begin{array}{l}-2.90 \\
-2.80 \\
-2.70 \\
-2.60 \\
-2.50\end{array}$ & $\begin{array}{l}189.46 \\
192.74 \\
195.99 \\
199.20 \\
202.38\end{array}$ & $\begin{array}{l}189.13 \\
192.42 \\
195.67 \\
198.88 \\
202.06\end{array}$ & $\begin{array}{l}188.80 \\
192.09 \\
195.34 \\
198.56 \\
201.74\end{array}$ & $\begin{array}{l}188.46 \\
191.76 \\
195.02 \\
198.24 \\
201.43\end{array}$ & $\begin{array}{l}188.13 \\
191.43 \\
194.70 \\
197.92 \\
201.11\end{array}$ & $\begin{array}{l}187.80 \\
191.11 \\
194.37 \\
197.60 \\
200.79\end{array}$ & $\begin{array}{l}187.47 \\
190.78 \\
194.05 \\
197.28 \\
200.48\end{array}$ & $\begin{array}{l}187.13 \\
190.45 \\
193.72 \\
196.96 \\
200.16\end{array}$ & $\begin{array}{l}186.80 \\
190.12 \\
193.40 \\
196.64 \\
199.84\end{array}$ & $\begin{array}{l}186.47 \\
189.79 \\
193.07 \\
196.31 \\
199.52\end{array}$ & $\begin{array}{l}186.13 \\
189.46 \\
192.74 \\
195.99 \\
199.20\end{array}$ & $\begin{array}{l}-2.90 \\
-2.80 \\
-2.70 \\
-2.60 \\
-2.50\end{array}$ \\
\hline $\begin{array}{l}-2.40 \\
-2.30 \\
-2.20 \\
-2.10 \\
-2.00\end{array}$ & $\begin{array}{l}205.52 \\
208.62 \\
211.70 \\
214.74 \\
217.76\end{array}$ & $\begin{array}{l}205.20 \\
208.31 \\
211.39 \\
214.44 \\
217.46\end{array}$ & $\begin{array}{l}204.89 \\
208.00 \\
211.09 \\
214.14 \\
217.16\end{array}$ & $\begin{array}{l}204.58 \\
207.69 \\
210.78 \\
213.83 \\
216.86\end{array}$ & $\begin{array}{l}204.26 \\
207.38 \\
210.47 \\
213.53 \\
216.55\end{array}$ & $\begin{array}{l}203.95 \\
207.07 \\
210.16 \\
213.22 \\
216.25\end{array}$ & $\begin{array}{l}203.64 \\
206.76 \\
209.86 \\
212.92 \\
215.95\end{array}$ & $\begin{array}{l}203.32 \\
206.45 \\
209.55 \\
212.61 \\
215.65\end{array}$ & $\begin{array}{l}203.01 \\
206.14 \\
209.24 \\
212.31 \\
215.35\end{array}$ & $\begin{array}{l}202.69 \\
205.83 \\
208.93 \\
212.00 \\
215.04\end{array}$ & $\begin{array}{l}202.38 \\
205.52 \\
208.62 \\
211.70 \\
214.74\end{array}$ & $\begin{array}{l}-2.40 \\
-2.30 \\
-2.20 \\
-2.10 \\
-2.00\end{array}$ \\
\hline $\begin{array}{l}-1.90 \\
-1.80 \\
-1.70 \\
-1.60 \\
-1.50\end{array}$ & $\begin{array}{l}220 \cdot 74 \\
223.70 \\
226.64 \\
229.54 \\
232.43\end{array}$ & $\begin{array}{l}220.45 \\
223.41 \\
226.34 \\
229.25 \\
232.14\end{array}$ & $\begin{array}{l}220.15 \\
223.11 \\
226.05 \\
228.96 \\
231.85\end{array}$ & $\begin{array}{l}219.85 \\
222.82 \\
225.76 \\
228.67 \\
231.56\end{array}$ & $\begin{array}{l}219.55 \\
222.52 \\
225.47 \\
228.38 \\
231.28\end{array}$ & $\begin{array}{l}219.25 \\
222.23 \\
225.17 \\
228.09 \\
230.99\end{array}$ & $\begin{array}{l}218.95 \\
221.93 \\
224 \cdot 88 \\
227 \cdot 80 \\
230 \cdot 70\end{array}$ & $\begin{array}{l}218.66 \\
221.63 \\
224.59 \\
227.51 \\
230.41\end{array}$ & $\begin{array}{l}218 \cdot 36 \\
221.34 \\
224 \cdot 29 \\
227 \cdot 22 \\
230 \cdot 12\end{array}$ & $\begin{array}{l}218.06 \\
221.04 \\
224.00 \\
226.93 \\
229.83\end{array}$ & $\begin{array}{l}217.76 \\
220.74 \\
223 \cdot 70 \\
226.64 \\
229.54\end{array}$ & $\begin{array}{l}-1.90 \\
-1.80 \\
-1.70 \\
-1.60 \\
-1.50\end{array}$ \\
\hline $\begin{array}{l}-1.40 \\
-1.30 \\
-1.20 \\
-1.10 \\
-1.00\end{array}$ & $\begin{array}{l}235.28 \\
238.12 \\
240.93 \\
243.73 \\
246.50\end{array}$ & $\begin{array}{l}235.00 \\
237.84 \\
240.65 \\
243.45 \\
246.22\end{array}$ & $\begin{array}{l}234.71 \\
237.55 \\
240.37 \\
243.17 \\
245.94\end{array}$ & $\begin{array}{l}234.43 \\
237.27 \\
240.09 \\
242.89 \\
245.67\end{array}$ & $\begin{array}{l}234.14 \\
236.99 \\
239.81 \\
242.61 \\
245.39\end{array}$ & $\begin{array}{l}233.86 \\
236.71 \\
239.53 \\
242.33 \\
245.11\end{array}$ & $\begin{array}{l}233.57 \\
236.42 \\
239.25 \\
242.05 \\
244.84\end{array}$ & $\begin{array}{l}233.29 \\
236.14 \\
238.97 \\
241.77 \\
244.56\end{array}$ & $\begin{array}{l}233.00 \\
235.85 \\
238.68 \\
241.49 \\
244.28\end{array}$ & $\begin{array}{l}232.71 \\
235.57 \\
238.40 \\
241.21 \\
244.00\end{array}$ & $\begin{array}{l}232.43 \\
235.28 \\
238.12 \\
240.93 \\
243.73\end{array}$ & $\begin{array}{l}-1.40 \\
-1.30 \\
-1.20 \\
-1.10 \\
-1.00\end{array}$ \\
\hline $\begin{array}{l}-0.90 \\
-0.80 \\
-0.70 \\
-0.60 \\
-0.50\end{array}$ & $\begin{array}{l}249.24 \\
251.97 \\
254.68 \\
257.37 \\
260.05\end{array}$ & $\begin{array}{l}248.97 \\
251.70 \\
254.41 \\
257.11 \\
259.78\end{array}$ & $\begin{array}{l}248.70 \\
251.43 \\
254 \cdot 14 \\
256.84 \\
259.51\end{array}$ & $\begin{array}{l}248.42 \\
251.16 \\
253.87 \\
256.57 \\
259.25\end{array}$ & $\begin{array}{l}248.15 \\
250.88 \\
253.60 \\
256.30 \\
258.98\end{array}$ & $\begin{array}{l}247.87 \\
250.61 \\
253.33 \\
256.03 \\
258.71\end{array}$ & $\begin{array}{l}247.60 \\
250.34 \\
253.06 \\
255.76 \\
258.45\end{array}$ & $\begin{array}{l}247.32 \\
250.07 \\
252.79 \\
255.49 \\
258.18\end{array}$ & $\begin{array}{l}247.05 \\
249.79 \\
252.52 \\
255.22 \\
257.91\end{array}$ & $\begin{array}{l}246.77 \\
249.52 \\
252.25 \\
254.95 \\
257.64\end{array}$ & $\begin{array}{l}246.50 \\
249.24 \\
251.97 \\
254.68 \\
257.37\end{array}$ & $\begin{array}{l}-0.90 \\
-0.80 \\
-0.70 \\
-0.60 \\
-0.50\end{array}$ \\
\hline $\begin{array}{r}-0.40 \\
-0.30 \\
-0.20 \\
-0.10 \\
0.00\end{array}$ & $\begin{array}{l}262.70 \\
265.34 \\
267.96 \\
270.56 \\
273.15\end{array}$ & $\begin{array}{l}262.44 \\
265.07 \\
267.70 \\
270.30 \\
272.89\end{array}$ & $\begin{array}{l}262.17 \\
264.81 \\
267.43 \\
270.04 \\
272.63\end{array}$ & $\begin{array}{l}261.91 \\
264.55 \\
267.17 \\
269.78 \\
272.37\end{array}$ & $\begin{array}{l}261.64 \\
264.28 \\
266.91 \\
269.52 \\
272.12\end{array}$ & $\begin{array}{l}261.38 \\
264.02 \\
266.65 \\
269.26 \\
271.86\end{array}$ & $\begin{array}{l}261.11 \\
263.76 \\
266.39 \\
269.00 \\
271.60\end{array}$ & $\begin{array}{l}260.84 \\
263.49 \\
266.12 \\
268.74 \\
271.34\end{array}$ & $\begin{array}{l}260.58 \\
263.23 \\
265.86 \\
268.48 \\
271.08\end{array}$ & $\begin{array}{l}260.31 \\
262.96 \\
265.60 \\
268.22 \\
270.82\end{array}$ & $\begin{array}{l}260.05 \\
262.70 \\
265.34 \\
267.96 \\
270.56\end{array}$ & $\begin{array}{r}-0.40 \\
-0.30 \\
-0.20 \\
-0.1 .0 \\
0.00\end{array}$ \\
\hline
\end{tabular}

\subsection{0} 40.01

48.99

56.88
64.07

70.77

83.07

94.26

99.54

109.56

118.99

127.93

132.25

140.59

144.63

152.48

156.30

163.75

184.79

188.1

194.70

197.92

204.26

210.47

213.53

219.55

222.52

228.38

234.1

239.8

245.3

248.1

253.60

256.30

261.64

266.91

272.12
271.86
271.60
$271 \cdot 34$

\begin{abstract}
.08
\end{abstract}

\begin{abstract}
.09
\end{abstract}
.10 $m V$ $\begin{array}{llll}.00 & .01 & .02 & .03\end{array}$
.03

\begin{abstract}
.04
$.05 \quad .06$
\end{abstract}




\begin{tabular}{|c|c|c|c|c|c|c|c|c|c|c|c|}
\hline $\begin{array}{l}T \\
k\end{array}$ & $\underset{\mu V}{E}$ & $\stackrel{S}{\boldsymbol{V}^{V} / K}$ & $\begin{array}{l}d S / d T \\
n V / K^{2}\end{array}$ & $\begin{array}{l}T \\
K\end{array}$ & $E_{\mu V}$ & $\mu \stackrel{S}{V} / K$ & $\begin{array}{l}d s / d T \\
n V / k^{2}\end{array}$ & $\begin{array}{l}T \\
K\end{array}$ & ${ }_{\mu V}^{E}$ & $\stackrel{S}{\mu V / K}$ & $\begin{array}{l}d S / d T \\
n V / K^{2}\end{array}$ \\
\hline $\begin{array}{l}0 \\
1 \\
2 \\
3 \\
4\end{array}$ & $\begin{array}{l}0.79 \\
1.66 \\
2.52 \\
3.38 \\
4.22\end{array}$ & $\begin{array}{l}0.882 \\
0.866 \\
0.855 \\
0.850 \\
0.847\end{array}$ & $\begin{array}{r}-18.8 \\
-12.9 \\
-8.0 \\
-3.9 \\
-0.6\end{array}$ & $\begin{array}{l}60 \\
61 \\
62 \\
63 \\
64\end{array}$ & $\begin{array}{r}90.46 \\
93.85 \\
97.35 \\
100.98 \\
104.72\end{array}$ & $\begin{array}{l}3.328 \\
3.444 \\
3.562 \\
3.683 \\
3.805\end{array}$ & $\begin{array}{l}114.7 \\
117.0 \\
119.3 \\
121.5 \\
123.5\end{array}$ & $\begin{array}{l}120 \\
121 \\
122 \\
123 \\
124\end{array}$ & $\begin{array}{l}537.51 \\
549.27 \\
561.16 \\
573.19 \\
585.35\end{array}$ & $\begin{array}{l}11.692 \\
11.826 \\
11.960 \\
12.093 \\
12.225\end{array}$ & $\begin{array}{l}134 \cdot 4 \\
133.8 \\
133.3 \\
132 \cdot 7 \\
132 \cdot 1\end{array}$ \\
\hline $\begin{array}{l}5 \\
6 \\
7 \\
8 \\
9\end{array}$ & $\begin{array}{l}5.07 \\
5.92 \\
6.77 \\
7.63 \\
8.50\end{array}$ & $\begin{array}{l}0.848 \\
0.851 \\
0.856 \\
0.863 \\
0.871\end{array}$ & $\begin{array}{l}2 \cdot 1 \\
4 \cdot 2 \\
5 \cdot 8 \\
7 \cdot 1 \\
8 \cdot 1\end{array}$ & $\begin{array}{l}65 \\
66 \\
67 \\
68 \\
69\end{array}$ & $\begin{array}{l}108.59 \\
112.58 \\
116.70 \\
120.95 \\
125.33\end{array}$ & $\begin{array}{l}3.930 \\
4.056 \\
4.185 \\
4.315 \\
4.446\end{array}$ & $\begin{array}{l}125.5 \\
127.4 \\
129.2 \\
130.9 \\
132.5\end{array}$ & $\begin{array}{l}125 \\
126 \\
127 \\
128 \\
129\end{array}$ & $\begin{array}{l}597.64 \\
610.06 \\
622.61 \\
635.30 \\
648.11\end{array}$ & $\begin{array}{l}12.357 \\
12.488 \\
12 \cdot 619 \\
12.749 \\
12.878\end{array}$ & $\begin{array}{l}131.5 \\
131.0 \\
130.4 \\
129.8 \\
129.3\end{array}$ \\
\hline $\begin{array}{l}10 \\
11 \\
12 \\
13 \\
14\end{array}$ & $\begin{array}{r}9.38 \\
10.46 \\
11.15 \\
12.06 \\
12.97\end{array}$ & $\begin{array}{l}0.879 \\
0.888 \\
0.898 \\
0.908 \\
0.919\end{array}$ & $\begin{array}{r}8.9 \\
9.5 \\
9.9 \\
10.3 \\
10.7\end{array}$ & $\begin{array}{l}70 \\
71 \\
72 \\
73 \\
74\end{array}$ & $\begin{array}{l}129.84 \\
134.49 \\
139.27 \\
144.19 \\
149.25\end{array}$ & $\begin{array}{l}4.580 \\
4.714 \\
4.850 \\
4.988 \\
5.126\end{array}$ & $\begin{array}{l}134 \cdot 0 \\
135.4 \\
136.7 \\
138 \cdot 0 \\
139.1\end{array}$ & $\begin{array}{l}130 \\
131 \\
132 \\
133 \\
134\end{array}$ & $\begin{array}{l}661.05 \\
674.13 \\
687.33 \\
700.65 \\
714.11\end{array}$ & $\begin{array}{l}13.007 \\
13.136 \\
13.264 \\
13.391 \\
13.518\end{array}$ & $\begin{array}{l}128.7 \\
128 \cdot 1 \\
127 \cdot 5 \\
126.9 \\
126.4\end{array}$ \\
\hline $\begin{array}{l}15 \\
16 \\
17 \\
18 \\
19\end{array}$ & $\begin{array}{l}13.89 \\
14 \cdot 83 \\
15.77 \\
16.73 \\
17.70\end{array}$ & $\begin{array}{l}0.929 \\
0.941 \\
0.952 \\
0.964 \\
0.977\end{array}$ & $\begin{array}{l}11.0 \\
11.4 \\
11.8 \\
12.3 \\
12.9\end{array}$ & $\begin{array}{l}75 \\
76 \\
77 \\
78 \\
79\end{array}$ & $\begin{array}{l}154.44 \\
159.78 \\
165.26 \\
170.88 \\
176.64\end{array}$ & $\begin{array}{l}5.266 \\
5.406 \\
5.548 \\
5.690 \\
5.834\end{array}$ & $\begin{array}{l}140.1 \\
141.1 \\
142.0 \\
142.8 \\
143.5\end{array}$ & $\begin{array}{l}135 \\
136 \\
137 \\
138 \\
139\end{array}$ & $\begin{array}{l}727.69 \\
741.39 \\
755.23 \\
769.18 \\
783.26\end{array}$ & $\begin{array}{l}13.644 \\
13.769 \\
13.894 \\
14.018 \\
14.142\end{array}$ & $\begin{array}{l}125 \cdot 8 \\
125 \cdot 2 \\
124 \cdot 6 \\
124 \cdot 0 \\
123.4\end{array}$ \\
\hline $\begin{array}{l}20 \\
21 \\
22 \\
23 \\
24\end{array}$ & $\begin{array}{l}18.69 \\
19.68 \\
20 \cdot 70 \\
21 \cdot 72 \\
22.77\end{array}$ & $\begin{array}{l}0.990 \\
1.004 \\
1.019 \\
1.035 \\
1.052\end{array}$ & $\begin{array}{l}13.6 \\
14.4 \\
15.4 \\
16.5 \\
17.8\end{array}$ & $\begin{array}{l}80 \\
81 \\
82 \\
83 \\
84\end{array}$ & $\begin{array}{l}182 \cdot 54 \\
188.59 \\
194 \cdot 79 \\
201.13 \\
207.61\end{array}$ & $\begin{array}{l}5.977 \\
6.122 \\
6.267 \\
6.412 \\
6.558\end{array}$ & $\begin{array}{l}144.1 \\
144.7 \\
145.2 \\
145.6 \\
145.9\end{array}$ & $\begin{array}{l}140 \\
141 \\
142 \\
143 \\
144\end{array}$ & $\begin{array}{l}797.47 \\
811.79 \\
826.24 \\
840.81 \\
855.50\end{array}$ & $\begin{array}{l}14 \cdot 265 \\
14.388 \\
14.510 \\
14.631 \\
14.752\end{array}$ & $\begin{array}{l}122 \cdot 8 \\
122 \cdot 2 \\
121 \cdot 6 \\
121 \cdot 0 \\
120 \cdot 4\end{array}$ \\
\hline $\begin{array}{l}25 \\
26 \\
27 \\
28 \\
29\end{array}$ & $\begin{array}{l}23 \cdot 83 \\
24 \cdot 91 \\
26 \cdot 01 \\
27 \cdot 13 \\
28 \cdot 28\end{array}$ & $\begin{array}{l}1.071 \\
1.091 \\
1.112 \\
1.136 \\
1.161\end{array}$ & $\begin{array}{l}19.2 \\
20.8 \\
22.5 \\
24.3 \\
26.3\end{array}$ & $\begin{array}{l}85 \\
86 \\
87 \\
88 \\
89\end{array}$ & $\begin{array}{l}214 \cdot 24 \\
221 \cdot 02 \\
227 \cdot 94 \\
235 \cdot 01 \\
242 \cdot 23\end{array}$ & $\begin{array}{l}6.704 \\
6.850 \\
6.997 \\
7.143 \\
7.290\end{array}$ & $\begin{array}{l}146.2 \\
146.4 \\
146.6 \\
146.7 \\
146.8\end{array}$ & $\begin{array}{l}145 \\
146 \\
147 \\
148 \\
149\end{array}$ & $\begin{array}{l}870 \cdot 32 \\
885 \cdot 25 \\
900 \cdot 30 \\
915 \cdot 47 \\
930 \cdot 75\end{array}$ & $\begin{array}{l}14.872 \\
14.991 \\
15.110 \\
15.229 \\
15.346\end{array}$ & $\begin{array}{l}119.8 \\
119.2 \\
118.6 \\
118.0 \\
117.4\end{array}$ \\
\hline $\begin{array}{l}30 \\
31 \\
32 \\
33 \\
34\end{array}$ & $\begin{array}{l}29.45 \\
30.66 \\
31.89 \\
33.16 \\
34.46\end{array}$ & $\begin{array}{l}1.188 \\
1.218 \\
1 \cdot 250 \\
1 \cdot 284 \\
1.321\end{array}$ & $\begin{array}{l}28 \cdot 4 \\
30 \cdot 7 \\
33 \cdot 1 \\
35 \cdot 6 \\
38 \cdot 2\end{array}$ & $\begin{array}{l}90 \\
91 \\
92 \\
93 \\
94\end{array}$ & $\begin{array}{l}249.59 \\
257.10 \\
264.76 \\
272.56 \\
280.51\end{array}$ & $\begin{array}{l}7.437 \\
7.584 \\
7.730 \\
7.877 \\
8.023\end{array}$ & $\begin{array}{l}146.8 \\
146.7 \\
146.6 \\
146.5 \\
146.3\end{array}$ & $\begin{array}{l}150 \\
151 \\
152 \\
153 \\
154\end{array}$ & $\begin{array}{r}946.16 \\
961.68 \\
977.32 \\
993.07 \\
1008.94\end{array}$ & $\begin{array}{l}15.463 \\
15.580 \\
15.696 \\
15.811 \\
15.925\end{array}$ & $\begin{array}{l}116.7 \\
116.1 \\
115.5 \\
114 \cdot 8 \\
114.2\end{array}$ \\
\hline $\begin{array}{l}35 \\
36 \\
37 \\
38 \\
39\end{array}$ & $\begin{array}{l}35.00 \\
37.18 \\
38.61 \\
40.08 \\
41.60\end{array}$ & $\begin{array}{l}1.360 \\
1.403 \\
1.448 \\
1.496 \\
1.547\end{array}$ & $\begin{array}{l}40.9 \\
43.7 \\
46.6 \\
49.5 \\
52.5\end{array}$ & $\begin{array}{l}95 \\
96 \\
97 \\
98 \\
99\end{array}$ & $\begin{array}{l}288.61 \\
296.85 \\
305.24 \\
313.78 \\
322.46\end{array}$ & $\begin{array}{l}8.170 \\
8.316 \\
8.461 \\
8.607 \\
8.752\end{array}$ & $\begin{array}{l}146.1 \\
145.9 \\
145.6 \\
145.3 \\
144.9\end{array}$ & $\begin{array}{l}155 \\
156 \\
157 \\
158 \\
159\end{array}$ & $\begin{array}{l}1024.92 \\
1041.02 \\
1057.23 \\
1073.55 \\
1089.98\end{array}$ & $\begin{array}{l}16.039 \\
16.152 \\
16.265 \\
16.377 \\
16.488\end{array}$ & $\begin{array}{l}113.6 \\
112.9 \\
112.3 \\
111.6 \\
111.0\end{array}$ \\
\hline $\begin{array}{l}40 \\
41 \\
42 \\
43 \\
44\end{array}$ & $\begin{array}{l}43.17 \\
44.80 \\
46.49 \\
48.24 \\
50.05\end{array}$ & $\begin{array}{l}1.601 \\
1.658 \\
1.718 \\
1.782 \\
1.848\end{array}$ & $\begin{array}{l}55.6 \\
58.7 \\
61.8 \\
65.0 \\
68.2\end{array}$ & $\begin{array}{l}100 \\
101 \\
102 \\
103 \\
104\end{array}$ & $\begin{array}{l}331.28 \\
340.25 \\
349.36 \\
358.62 \\
368.02\end{array}$ & $\begin{array}{l}8.897 \\
9.041 \\
9.185 \\
9.328 \\
9.472\end{array}$ & $\begin{array}{l}144.6 \\
144.2 \\
143.8 \\
143.3 \\
142.9\end{array}$ & $\begin{array}{l}160 \\
161 \\
162 \\
163 \\
164\end{array}$ & $\begin{array}{l}1106.52 \\
1123.18 \\
1139.94 \\
1156.81 \\
1173.80\end{array}$ & $\begin{array}{l}16.599 \\
16.709 \\
16.818 \\
16.927 \\
17.035\end{array}$ & $\begin{array}{l}110.4 \\
109.7 \\
109.1 \\
108.4 \\
107.8\end{array}$ \\
\hline $\begin{array}{l}45 \\
46 \\
47 \\
48 \\
49\end{array}$ & $\begin{array}{l}51.94 \\
53.89 \\
55.92 \\
58.03 \\
60.21\end{array}$ & $\begin{array}{l}1.918 \\
1.991 \\
2.067 \\
2.146 \\
2.229\end{array}$ & $\begin{array}{l}71 \cdot 3 \\
74 \cdot 5 \\
77.7 \\
80.8 \\
83.9\end{array}$ & $\begin{array}{l}105 \\
106 \\
107 \\
108 \\
109\end{array}$ & $\begin{array}{l}377 \cdot 56 \\
387.25 \\
397.07 \\
407.04 \\
417.15\end{array}$ & $\begin{array}{r}9.614 \\
9.756 \\
9.898 \\
10.039 \\
10.180\end{array}$ & $\begin{array}{l}142.4 \\
141.9 \\
141.5 \\
140.9 \\
140.4\end{array}$ & $\begin{array}{l}165 \\
166 \\
167 \\
168 \\
169\end{array}$ & $\begin{array}{l}1190.88 \\
1208 \cdot 08 \\
1225.38 \\
1242 \cdot 79 \\
1260.30\end{array}$ & $\begin{array}{l}17.143 \\
17.249 \\
17.356 \\
17.461 \\
17.566\end{array}$ & $\begin{array}{l}107.1 \\
106 \cdot 5 \\
105.9 \\
105.2 \\
104.6\end{array}$ \\
\hline $\begin{array}{l}50 \\
51 \\
52 \\
53 \\
54\end{array}$ & $\begin{array}{l}62 \cdot 48 \\
64 \cdot 84 \\
67 \cdot 29 \\
69.83 \\
72.47\end{array}$ & $\begin{array}{l}2.314 \\
2.403 \\
2.494 \\
2.589 \\
2.686\end{array}$ & $\begin{array}{l}87.0 \\
90.1 \\
93.1 \\
96.0 \\
98.9\end{array}$ & $\begin{array}{ll}1 & 10 \\
1 & 111 \\
1 & 12 \\
1 & 13 \\
1 & 14\end{array}$ & $\begin{array}{l}427.40 \\
437.79 \\
448.32 \\
458.99 \\
469.80\end{array}$ & $\begin{array}{l}10.320 \\
10.460 \\
10.599 \\
10.738 \\
10.876\end{array}$ & $\begin{array}{l}139.9 \\
139.4 \\
138.8 \\
138.3 \\
137.8\end{array}$ & $\begin{array}{l}170 \\
171 \\
172 \\
173 \\
174\end{array}$ & $\begin{array}{l}1277.92 \\
1295.65 \\
1313.47 \\
1331.40 \\
1349.43\end{array}$ & $\begin{array}{l}17.670 \\
17.774 \\
17.877 \\
17.979 \\
18.081\end{array}$ & $\begin{array}{l}104 \cdot 0 \\
103 \cdot 3 \\
102 \cdot 7 \\
102 \cdot 1 \\
101 \cdot 5\end{array}$ \\
\hline $\begin{array}{l}55 \\
56 \\
57 \\
58 \\
59\end{array}$ & $\begin{array}{l}75 \cdot 20 \\
78.04 \\
80.98 \\
84.03 \\
87.19\end{array}$ & $\begin{array}{l}2.786 \\
2.890 \\
2.995 \\
3.104 \\
3.215\end{array}$ & $\begin{array}{l}101 \cdot 7 \\
104 \cdot 5 \\
107 \cdot 1 \\
109 \cdot 7 \\
112 \cdot 3\end{array}$ & $\begin{array}{l}115 \\
116 \\
117 \\
118 \\
119\end{array}$ & $\begin{array}{l}480.74 \\
491.82 \\
503.04 \\
514.40 \\
525.89\end{array}$ & $\begin{array}{l}11.013 \\
11.150 \\
11.286 \\
11.422 \\
11.557\end{array}$ & $\begin{array}{l}137.2 \\
136 \cdot 6 \\
136 \cdot 1 \\
135 \cdot 5 \\
135.0\end{array}$ & $\begin{array}{l}175 \\
176 \\
177 \\
178 \\
179\end{array}$ & $\begin{array}{l}1367.56 \\
1385.79 \\
1404.13 \\
1422.56 \\
1441.09\end{array}$ & $\begin{array}{l}18.182 \\
18.283 \\
18.383 \\
18.482 \\
18.581\end{array}$ & $\begin{array}{r}100.9 \\
100.3 \\
99.7 \\
99.1 \\
98.5\end{array}$ \\
\hline 60 & 90.46 & $3 \cdot 328$ & 114.7 & 120 & 537.51 & 11.692 & 134.4 & 180 & 1459.72 & 18.679 & 98.0 \\
\hline
\end{tabular}




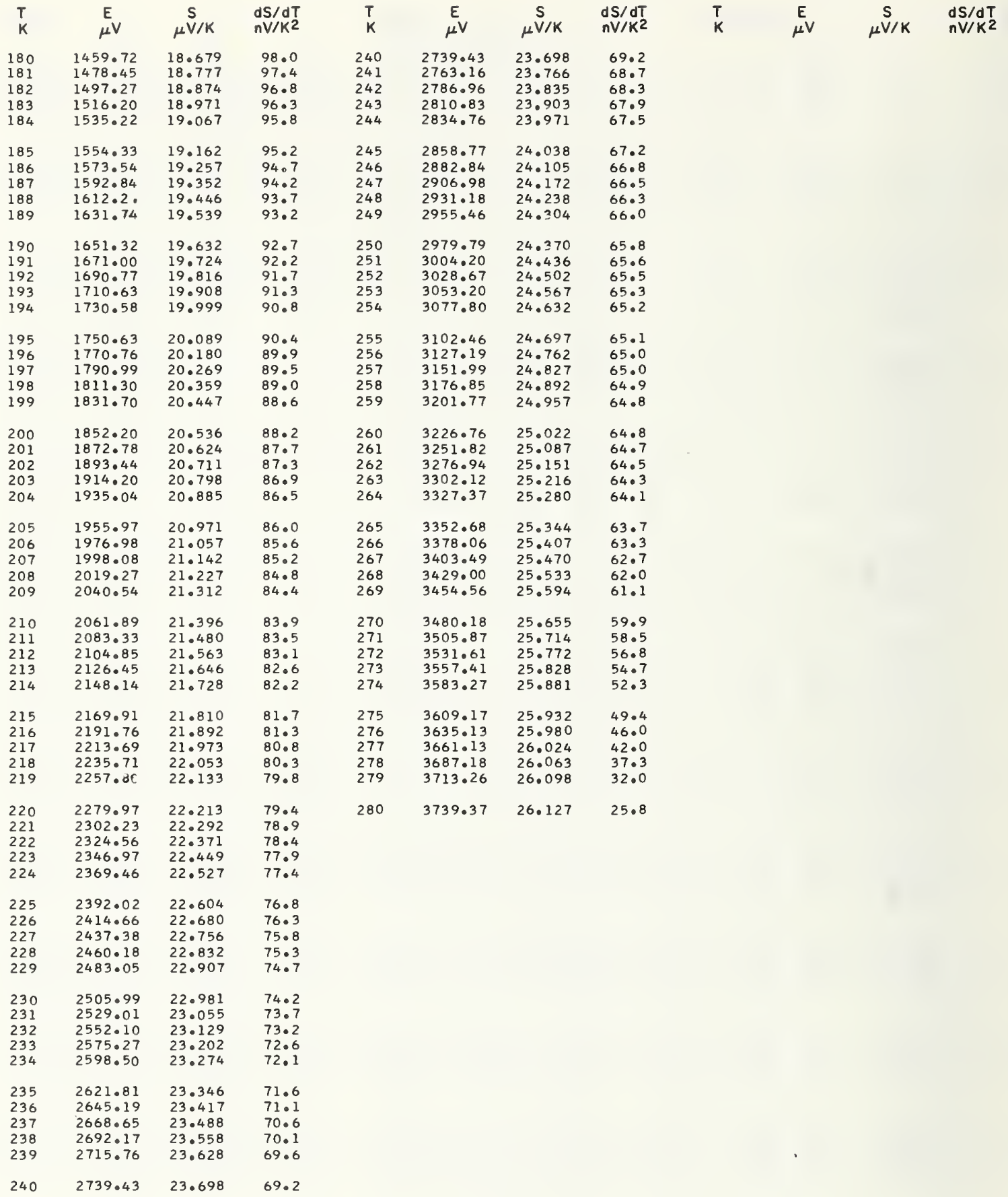




\begin{tabular}{|c|c|c|c|c|c|c|c|c|c|c|c|}
\hline $\begin{array}{l}T \\
K\end{array}$ & $\begin{array}{l}\mathrm{E} \\
\mu v\end{array}$ & $\stackrel{S}{\mathrm{~S}} / \mathrm{K}$ & $\begin{array}{l}d s / d t \\
n v / k^{2}\end{array}$ & $\begin{array}{l}T \\
k\end{array}$ & $\begin{array}{c}E \\
\mu V\end{array}$ & $\mu_{\mu V / K}^{S}$ & $\begin{array}{l}\mathrm{d} s / \mathrm{d} T \\
n V / k^{2}\end{array}$ & $\begin{array}{l}T \\
K\end{array}$ & $\underset{\mu v}{E}$ & $\stackrel{s}{\mu V / K}$ & $\begin{array}{l}d s / d T \\
n V / K^{2}\end{array}$ \\
\hline $\begin{array}{l}0 \\
1 \\
2 \\
3 \\
4\end{array}$ & $\begin{array}{r}0.00 \\
-1.02 \\
-1.39 \\
-1.17 \\
-0.39\end{array}$ & $\begin{array}{r}-1.355 \\
-0.688 \\
-0.069 \\
0.509 \\
1.051\end{array}$ & $\begin{array}{l}693 \cdot 1 \\
642 \cdot 1 \\
597 \cdot 8 \\
559 \cdot 3 \\
526 \cdot 0\end{array}$ & $\begin{array}{l}60 \\
61 \\
62 \\
63 \\
64\end{array}$ & $\begin{array}{l}614.42 \\
632.81 \\
651.36 \\
670.07 \\
688.93\end{array}$ & $\begin{array}{l}18.311 \\
18.473 \\
18.631 \\
18.784 \\
18.933\end{array}$ & $\begin{array}{l}164.6 \\
159.9 \\
155.3 \\
150.9 \\
146.6\end{array}$ & $\begin{array}{l}120 \\
121 \\
122 \\
123 \\
124\end{array}$ & $\begin{array}{l}1907.67 \\
1931.62 \\
1955.64 \\
1979.72 \\
2003.86\end{array}$ & $\begin{array}{l}23.921 \\
23.985 \\
24.050 \\
24.114 \\
24.177\end{array}$ & $\begin{array}{l}64.8 \\
64.5 \\
64.2 \\
63.9 \\
63.6\end{array}$ \\
\hline $\begin{array}{l}5 \\
6 \\
7 \\
8 \\
9\end{array}$ & $\begin{array}{r}0.92 \\
2.73 \\
5.01 \\
7.74 \\
10.91\end{array}$ & $\begin{array}{l}1.563 \\
2.047 \\
2.510 \\
2.953 \\
3.379\end{array}$ & $\begin{array}{l}497 \cdot 4 \\
472 \cdot 9 \\
452 \cdot 0 \\
434 \cdot 3 \\
419.3\end{array}$ & $\begin{array}{l}65 \\
66 \\
67 \\
68 \\
69\end{array}$ & $\begin{array}{l}707 \cdot 93 \\
727.08 \\
746 \cdot 37 \\
765 \cdot 79 \\
785 \cdot 34\end{array}$ & $\begin{array}{l}19.077 \\
19.218 \\
19.354 \\
19.487 \\
19.617\end{array}$ & $\begin{array}{l}142.5 \\
138.5 \\
134.7 \\
131 \cdot 1 \\
127.6\end{array}$ & $\begin{array}{l}125 \\
126 \\
127 \\
128 \\
129\end{array}$ & $\begin{array}{l}2028.07 \\
2052.34 \\
2076.68 \\
2101.08 \\
2125.54\end{array}$ & $\begin{array}{l}24.241 \\
24 \cdot 304 \\
24.367 \\
24.430 \\
24.492\end{array}$ & $\begin{array}{l}63 \cdot 3 \\
63 \cdot 0 \\
62 \cdot 8 \\
62 \cdot 6 \\
62.4\end{array}$ \\
\hline $\begin{array}{l}10 \\
11 \\
12 \\
13 \\
14\end{array}$ & $\begin{array}{l}14.50 \\
18.49 \\
24.88 \\
27.66 \\
32.81\end{array}$ & $\begin{array}{l}3.792 \\
4.193 \\
4.585 \\
4.968 \\
5.345\end{array}$ & $\begin{array}{l}406.6 \\
396.0 \\
387.2 \\
379.8 \\
373.6\end{array}$ & $\begin{array}{l}70 \\
71 \\
72 \\
73 \\
74\end{array}$ & $\begin{array}{l}805.02 \\
824.82 \\
844.75 \\
864.79 \\
884.95\end{array}$ & $\begin{array}{l}19.743 \\
19.865 \\
19.985 \\
20.101 \\
20.215\end{array}$ & $\begin{array}{l}124.3 \\
121.1 \\
118.0 \\
115.1 \\
112.4\end{array}$ & $\begin{array}{l}130 \\
131 \\
132 \\
133 \\
134\end{array}$ & $\begin{array}{l}2150.06 \\
2174.65 \\
2199.30 \\
2224.00 \\
2248.78\end{array}$ & $\begin{array}{l}24.554 \\
24.616 \\
24.678 \\
24.740 \\
24.802\end{array}$ & $\begin{array}{l}62 \cdot 2 \\
62 \cdot 0 \\
61 \cdot 8 \\
61 \cdot 6 \\
61 \cdot 5\end{array}$ \\
\hline $\begin{array}{l}15 \\
16 \\
17 \\
18 \\
19\end{array}$ & $\begin{array}{l}38.34 \\
44.24 \\
50.51 \\
57.13 \\
64.11\end{array}$ & $\begin{array}{l}5.715 \\
6.082 \\
6.444 \\
6.803 \\
7.158\end{array}$ & $\begin{array}{l}368.4 \\
364.1 \\
360.4 \\
357.2 \\
354.3\end{array}$ & $\begin{array}{l}75 \\
76 \\
77 \\
78 \\
79\end{array}$ & $\begin{array}{l}905.22 \\
925.60 \\
946.09 \\
966.68 \\
987.38\end{array}$ & $\begin{array}{l}20.326 \\
20.435 \\
20.541 \\
20.645 \\
20.746\end{array}$ & $\begin{array}{l}109.8 \\
107.3 \\
104.9 \\
102.7 \\
100.5\end{array}$ & $\begin{array}{l}135 \\
136 \\
137 \\
138 \\
139\end{array}$ & $\begin{array}{l}2273.61 \\
2298.50 \\
2323.46 \\
2348.47 \\
2373.55\end{array}$ & $\begin{array}{l}24.863 \\
24.924 \\
24.985 \\
25.047 \\
25.108\end{array}$ & $\begin{array}{l}61 \cdot 4 \\
61 \cdot 2 \\
61 \cdot 1 \\
61 \cdot 1 \\
61 \cdot 0\end{array}$ \\
\hline $\begin{array}{l}20 \\
21 \\
22 \\
23 \\
24\end{array}$ & $\begin{array}{r}71.44 \\
79.13 \\
87.17 \\
95.55 \\
104.28\end{array}$ & $\begin{array}{l}7.511 \\
7.862 \\
8.210 \\
8.556 \\
8.899\end{array}$ & $\begin{array}{l}351 \cdot 7 \\
349 \cdot 3 \\
346.9 \\
344 \cdot 5 \\
342 \cdot 1\end{array}$ & $\begin{array}{l}80 \\
81 \\
82 \\
83 \\
84\end{array}$ & $\begin{array}{l}1008.18 \\
1029.07 \\
1050.06 \\
1071.15 \\
1092.33\end{array}$ & $\begin{array}{l}20.846 \\
20.943 \\
21.039 \\
21.133 \\
21.225\end{array}$ & $\begin{array}{l}98.5 \\
96.6 \\
94.8 \\
93.1 \\
91.5\end{array}$ & $\begin{array}{l}140 \\
141 \\
142 \\
143 \\
144\end{array}$ & $\begin{array}{l}2398.69 \\
2423.89 \\
2449.15 \\
2474.47 \\
2499.85\end{array}$ & $\begin{array}{l}25.168 \\
25.229 \\
25.290 \\
25.351 \\
25.412\end{array}$ & $\begin{array}{l}60.9 \\
60.9 \\
60.8 \\
60.8 \\
60.8\end{array}$ \\
\hline $\begin{array}{l}25 \\
26 \\
27 \\
28 \\
29\end{array}$ & $\begin{array}{l}113.35 \\
122.76 \\
132 \cdot 50 \\
142.58 \\
152.99\end{array}$ & $\begin{array}{r}9.240 \\
9.578 \\
9.913 \\
10.246 \\
10.575\end{array}$ & $\begin{array}{l}339.6 \\
336.9 \\
334.0 \\
330.9 \\
327.6\end{array}$ & $\begin{array}{l}85 \\
86 \\
87 \\
88 \\
89\end{array}$ & $\begin{array}{l}1113.60 \\
1134.96 \\
1156.41 \\
1177.94 \\
1199.57\end{array}$ & $\begin{array}{l}21.316 \\
21.405 \\
21.493 \\
21.579 \\
21.665\end{array}$ & $\begin{array}{l}90.0 \\
88.5 \\
87.2 \\
85.9 \\
84.7\end{array}$ & $\begin{array}{l}145 \\
146 \\
147 \\
148 \\
149\end{array}$ & $\begin{array}{l}2525.29 \\
2550.79 \\
2576.36 \\
2601.98 \\
2627.67\end{array}$ & $\begin{array}{l}25.473 \\
25.533 \\
25.594 \\
25.655 \\
25.716\end{array}$ & $\begin{array}{l}60.8 \\
60.8 \\
60.8 \\
60.8 \\
60.8\end{array}$ \\
\hline $\begin{array}{l}30 \\
31 \\
32 \\
33 \\
34\end{array}$ & $\begin{array}{l}163.73 \\
174.79 \\
186.18 \\
197.88 \\
209.89\end{array}$ & $\begin{array}{l}10.901 \\
11.223 \\
11.542 \\
11.856 \\
12.166\end{array}$ & $\begin{array}{l}324 \cdot 1 \\
320 \cdot 4 \\
316.4 \\
312 \cdot 2 \\
307.8\end{array}$ & $\begin{array}{l}90 \\
91 \\
92 \\
93 \\
94\end{array}$ & $\begin{array}{l}1221.27 \\
1243.06 \\
1264.94 \\
1286.89 \\
1308.92\end{array}$ & $\begin{array}{l}21.749 \\
21.832 \\
21.914 \\
21.994 \\
22.074\end{array}$ & $\begin{array}{l}83.5 \\
82.4 \\
81: 4 \\
80.4 \\
79.5\end{array}$ & $\begin{array}{l}150 \\
151 \\
152 \\
153 \\
154\end{array}$ & $\begin{array}{l}2653.41 \\
2679.22 \\
2705.09 \\
2731.02 \\
2757.00\end{array}$ & $\begin{array}{l}25.776 \\
25.837 \\
25.898 \\
25.959 \\
26.020\end{array}$ & $\begin{array}{l}60.8 \\
60.8 \\
60.9 \\
60.9 \\
60.9\end{array}$ \\
\hline $\begin{array}{l}35 \\
36 \\
37 \\
38 \\
39\end{array}$ & $\begin{array}{l}222.21 \\
234.83 \\
247.75 \\
260.96 \\
274.47\end{array}$ & $\begin{array}{l}12.472 \\
12.772 \\
13.068 \\
13.359 \\
13.644\end{array}$ & $\begin{array}{l}303 \cdot 1 \\
298 \cdot 3 \\
293 \cdot 2 \\
288 \cdot 0 \\
282.6\end{array}$ & $\begin{array}{l}95 \\
96 \\
97 \\
98 \\
99\end{array}$ & $\begin{array}{l}1331.04 \\
1353.23 \\
1375.50 \\
1397.85 \\
1420.27\end{array}$ & $\begin{array}{l}22.153 \\
22.232 \\
22.309 \\
22.385 \\
22.461\end{array}$ & $\begin{array}{l}78.6 \\
77.7 \\
76.9 \\
76.1 \\
75.4\end{array}$ & $\begin{array}{l}155 \\
156 \\
157 \\
158 \\
159\end{array}$ & $\begin{array}{l}2783.05 \\
2809.17 \\
2835.34 \\
2861.57 \\
2887.87\end{array}$ & $\begin{array}{l}26.081 \\
26.142 \\
26.203 \\
26.264 \\
26.325\end{array}$ & $\begin{array}{l}61 \cdot 0 \\
61 \cdot 0 \\
61 \cdot 0 \\
61 \cdot 1 \\
61 \cdot 1\end{array}$ \\
\hline $\begin{array}{l}40 \\
41 \\
42 \\
43 \\
44\end{array}$ & $\begin{array}{l}288 \cdot 25 \\
302 \cdot 31 \\
316 \cdot 65 \\
331 \cdot 24 \\
346 \cdot 10\end{array}$ & $\begin{array}{l}13.924 \\
14.198 \\
14.467 \\
14 \cdot 730 \\
14.987\end{array}$ & $\begin{array}{l}277 \cdot 1 \\
271 \cdot 5 \\
265.8 \\
260.0 \\
254.1\end{array}$ & $\begin{array}{l}100 \\
101 \\
102 \\
103 \\
104\end{array}$ & $\begin{array}{l}1442.77 \\
1465.34 \\
1487.99 \\
1510.71 \\
1533.51\end{array}$ & $\begin{array}{l}22.536 \\
22.611 \\
22.684 \\
22.757 \\
22.830\end{array}$ & $\begin{array}{l}74.7 \\
74.0 \\
73.4 \\
72.8 \\
72.2\end{array}$ & $\begin{array}{l}160 \\
161 \\
162 \\
163 \\
164\end{array}$ & $\begin{array}{l}2914 \cdot 22 \\
2940.64 \\
2967.12 \\
2993.65 \\
3020.25\end{array}$ & $\begin{array}{l}26.386 \\
26.447 \\
26.508 \\
26.569 \\
26.631\end{array}$ & $\begin{array}{l}61 \cdot 1 \\
61 \cdot 1 \\
61 \cdot 2 \\
61 \cdot 2 \\
61 \cdot 2\end{array}$ \\
\hline $\begin{array}{l}45 \\
46 \\
47 \\
48 \\
49\end{array}$ & $\begin{array}{l}361.22 \\
376.58 \\
392.18 \\
408.02 \\
424.09\end{array}$ & $\begin{array}{l}15.238 \\
15.483 \\
15.723 \\
15.956 \\
16.183\end{array}$ & $\begin{array}{l}248 \cdot 2 \\
242 \cdot 3 \\
236 \cdot 3 \\
230.4 \\
224.4\end{array}$ & $\begin{array}{l}105 \\
106 \\
107 \\
108 \\
109\end{array}$ & $\begin{array}{l}1556 \cdot 37 \\
1579 \cdot 31 \\
1602 \cdot 32 \\
1625 \cdot 40 \\
1648.55\end{array}$ & $\begin{array}{l}22.902 \\
22.973 \\
23.044 \\
23.114 \\
23.184\end{array}$ & $\begin{array}{l}71.6 \\
71.0 \\
70.5 \\
69.9 \\
69.4\end{array}$ & $\begin{array}{l}165 \\
166 \\
167 \\
168 \\
169\end{array}$ & $\begin{array}{l}3046.92 \\
3073.64 \\
3100.42 \\
3127.27 \\
3154.17\end{array}$ & $\begin{array}{l}26.692 \\
26.753 \\
26.814 \\
26.875 \\
26.936\end{array}$ & $\begin{array}{l}61 \cdot 2 \\
61 \cdot 2 \\
61 \cdot 1 \\
61 \cdot 1 \\
61 \cdot 1\end{array}$ \\
\hline $\begin{array}{l}50 \\
51 \\
52 \\
53 \\
54\end{array}$ & $\begin{array}{l}440.38 \\
456.90 \\
473.62 \\
490.56 \\
507.69\end{array}$ & $\begin{array}{l}16.405 \\
16.620 \\
16.830 \\
17.034 \\
17.233\end{array}$ & $\begin{array}{l}218 \cdot 6 \\
212 \cdot 7 \\
207.0 \\
201 \cdot 3 \\
195.7\end{array}$ & $\begin{array}{ll}11 & 0 \\
1 & 11 \\
1 & 12 \\
1 & 13 \\
1 & 14\end{array}$ & $\begin{array}{l}1671.76 \\
1695.05 \\
1718.41 \\
1741.83 \\
1765.32\end{array}$ & $\begin{array}{l}23.253 \\
23.322 \\
23.390 \\
23.458 \\
23.525\end{array}$ & $\begin{array}{l}68.9 \\
68.5 \\
68.0 \\
67.6 \\
67.1\end{array}$ & $\begin{array}{l}170 \\
171 \\
172 \\
173 \\
174\end{array}$ & $\begin{array}{l}3181 \cdot 14 \\
3208 \cdot 17 \\
3235 \cdot 26 \\
3262 \cdot 41 \\
3289.62\end{array}$ & $\begin{array}{l}26.997 \\
27.058 \\
27.119 \\
27.180 \\
27.241\end{array}$ & $\begin{array}{l}61 \cdot 1 \\
61 \cdot 0 \\
61 \cdot 0 \\
60 \cdot 9 \\
60 \cdot 8\end{array}$ \\
\hline $\begin{array}{l}55 \\
56 \\
57 \\
58 \\
59\end{array}$ & $\begin{array}{l}525 \cdot 02 \\
542.54 \\
560.24 \\
578.13 \\
596.19\end{array}$ & $\begin{array}{l}17.426 \\
17.613 \\
17.795 \\
17.972 \\
18.144\end{array}$ & $\begin{array}{l}190.2 \\
184.8 \\
179.6 \\
174.4 \\
169.4\end{array}$ & $\begin{array}{l}115 \\
116 \\
117 \\
118 \\
119\end{array}$ & $\begin{array}{l}1788.88 \\
1812.51 \\
1836.20 \\
1859.95 \\
1883.78\end{array}$ & $\begin{array}{l}23.592 \\
23.658 \\
23.724 \\
23.790 \\
23.856\end{array}$ & $\begin{array}{l}66.7 \\
66.3 \\
65.9 \\
65.5 \\
65.2\end{array}$ & $\begin{array}{l}175 \\
176 \\
177 \\
178 \\
179\end{array}$ & $\begin{array}{l}3316.89 \\
3344.22 \\
3371.61 \\
3399.07 \\
3426.58\end{array}$ & $\begin{array}{l}27.302 \\
27.363 \\
27.423 \\
27.484 \\
27.544\end{array}$ & $\begin{array}{l}60.8 \\
60.7 \\
60.6 \\
60.5 \\
60.4\end{array}$ \\
\hline 60 & 614.42 & 18.311 & 164.6 & 120 & 1907.67 & 23.921 & 64.8 & 180 & 3454.16 & 27.605 & 60.3 \\
\hline
\end{tabular}


$\begin{array}{ll}180 & 3454.16 \\ 181 & 3481.79\end{array}$

18

183

184

185

186

187
188

189

190

191

192

193

19

195

196

197
198

199

200

201

202

204

20

206

207
208

209

210

211

212

214

215

216

217

218

219

220

221

222

223
224

225

226
227

228
229

230

231
232

232
233

234

235

236

237

238

239

240

3509.49

3537.24

3565.06

3592.93

3620.86

$3648 \cdot 86$

3676.91

3705.02

3733.20

3761.43

3789.72

$3818 \cdot 07$

3846.47

3874.94

3903.46

3932.04

3960.69

3989.38

$4018 \cdot 14$

4046.96

4075.83

4104.76

4133.75

4162.79

4191.90

4221.06

4250.28

4308.89

4338.28

4367.73

4397.24

4426.80

4456.42

4486.10

4515.84

4545.63

4575.49

$4605 \cdot 40$

4635.36

$4665 \cdot 39$

4695.47

4725.61

$4755 \cdot 81$

4786.00

4816.98

4846.75

4877.18

$4907 \cdot 66$

4938.20

4968.80

4999.46

5030.17

5060.94

5091.77

5122.65

5153.59

5184.59

\begin{tabular}{|c|}
\hline$\stackrel{\mathrm{S}}{\mu \mathrm{V} / K}$ \\
\hline $\begin{array}{l}27.605 \\
27.665 \\
27.725 \\
27.785 \\
27.845\end{array}$ \\
\hline $\begin{array}{l}27.905 \\
27.964 \\
28.024 \\
28.083 \\
28.142\end{array}$ \\
\hline $\begin{array}{l}28.201 \\
28.260 \\
28.319 \\
28.378 \\
28.436\end{array}$ \\
\hline 28.495 \\
\hline $\begin{array}{l}28.553 \\
28.612 \\
28.670 \\
28.728\end{array}$ \\
\hline $\begin{array}{l}28.786 \\
28.844 \\
28.902 \\
28.959 \\
29.017\end{array}$ \\
\hline $\begin{array}{l}29.075 \\
29.133 \\
29.190 \\
29.248 \\
29.305\end{array}$ \\
\hline
\end{tabular}

$d S / d T$
$n V / K^{2}$

60.3

4279.55

29.363

29.420

29.478

29.536

29.593

29.651

29.708

29.766

29.823

29.881

29.939

29.996

30.054

30.111

30.169

30.227

30.284

30.342

30.399

30.456

60.2

59.9

59.8

59.7

59.5

59.4

$59 \cdot 3$
59.2

59.0

58.9

58.8

58.7

58.5

58.4

58.3

58.2

58.1

58.0

58.0

57.9

57.8

57.8

57.7

$57 \cdot 7$

$57 \cdot 6$

57.6

57.6

$57 \cdot 6$

57.6

57.6

57.6

57.6
57.6

$57 \cdot 6$

57.6

57.6

57.6

57.6

57.6

57.6

57.6

57.6

57.6

57.5

57.5

57.4

57.4

57.3

$30.514 \quad 57.2$

30.571

30.628

30.685

56.9

$56 \cdot 8$

30.798

30.855

56.6

56.5

56.3

56.2

30.968

31.024

56.0

$\begin{array}{lll}5215.64 & 31.080 \quad 55.8\end{array}$

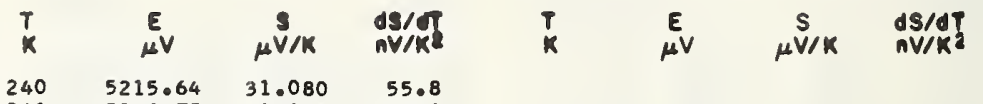

$\begin{array}{llll}241 & 5246.75 & 31.135 & 55.8\end{array}$

$242 \quad 5277.91 \quad 31.191 \quad 55.5$

$243 \quad 5309.13 \quad 31.246 \quad 55.3$

$244 \quad 5340.40 \quad 31.301 \quad 55.1$

$\begin{array}{llll}245 & 5371.73 & 31.356 & 54.9\end{array}$

$245 \quad 5403.11 \quad 31.411 \quad 54.8$

$\begin{array}{llll}247 & 5434.55 & 31.466 & 54.6\end{array}$

$248 \quad 5466.05 \quad 31.521 \quad 54.5$

$\begin{array}{llll}249 & 5497.59 & 31.575 & 54.4\end{array}$

$\begin{array}{llll}250 & 5529.20 \quad 31.629 & 54.3\end{array}$

$251 \quad 5560.85 \quad 31.684 \quad 54.3$

$\begin{array}{llll}252 & 5592.56 & 31.738 & 54.2\end{array}$

$253 \quad 5624.33 \quad 31.792 \quad 5402$

$\begin{array}{lll}5656.15 & 31.847 & 54.3\end{array}$

255

256

258

259

5688.02

$5719.95 \quad 31.955$

$5751.93 \quad 32.010$

$5783.97 \quad 32.064$

$5816.06 \quad 32.119$

$5848.21 \quad 32.174$

$5880.41 \quad 32.228$

$5912.66 \quad 32.284$

$5944.97 \quad 32.339$

$5977.34 \quad 32.394$

$6009.76 \quad 32.449$

$6042.24 \quad 32.504$

$6074.77 \quad 32.559$

$6107.36 \quad 32.614$

$6140.00 \quad 32.668$

32.721

$\begin{array}{ll}6172.69 & 32.721 \\ 6205.44 & 32.773\end{array}$

$\begin{array}{ll}6205.44 & 32.773 \\ 6238.24 & 32.823\end{array}$

$6271.08 \quad 32.872$

32.919

6336.92

32.962

$6369.90 \quad 33.002$

6402.92

6435.98

33.037

33.067

33.090

$54 \cdot 3$

54.4

54.5

$54 \cdot 6$

54.7

54.9

55.0

55.1

$55 \cdot 2$

55.2

$55 \cdot 2$

55.0

54.7

54.3

53.6

52.7

51.4

49.8

$47 \cdot 7$

45.0

$41 \cdot 7$

37.6

32.7

26.7

19.6

280

$6502.15 \quad 33.105$

$11 \cdot 2$ 


\begin{tabular}{|c|c|c|c|c|c|c|c|c|c|c|c|}
\hline $\begin{array}{l}T \\
K\end{array}$ & $\begin{array}{c}E \mathrm{~V} \\
\mu \mathrm{V}\end{array}$ & $\mu \stackrel{S}{\mu V / K}$ & $\begin{array}{l}d s / d T \\
n V / k^{2}\end{array}$ & $\begin{array}{l}\mathbf{T} \\
\mathrm{K}\end{array}$ & $\begin{array}{c}E \\
\mu V\end{array}$ & $\begin{array}{c}S \\
\mu V / K\end{array}$ & $\begin{array}{l}d s / d T \\
n v / k^{2}\end{array}$ & $\begin{array}{l}T \\
k\end{array}$ & $\begin{array}{l}E \\
\mu V\end{array}$ & $\mu^{S}{ }^{\mathrm{V} / \mathrm{K}}$ & $\begin{array}{l}d s / d T \\
n V / k^{2}\end{array}$ \\
\hline $\begin{array}{l}0 \\
1 \\
2 \\
3 \\
4\end{array}$ & $\begin{array}{l}-0.22 \\
-0.93 \\
-1.44 \\
-1.76 \\
-1.88\end{array}$ & $\begin{array}{l}-0.813 \\
-0.611 \\
-0.414 \\
-0.218 \\
-0.025\end{array}$ & $\begin{array}{l}203.5 \\
199.4 \\
196.3 \\
194.3 \\
193.0\end{array}$ & $\begin{array}{l}60 \\
61 \\
62 \\
63 \\
64\end{array}$ & $\begin{array}{l}293.10 \\
302.58 \\
312.13 \\
321.76 \\
331.46\end{array}$ & $\begin{array}{l}9.435 \\
9.515 \\
9.593 \\
9.666 \\
9.737\end{array}$ & $\begin{array}{l}82.2 \\
78.8 \\
75.5 \\
72.3 \\
69.2\end{array}$ & $\begin{array}{l}120 \\
121 \\
122 \\
123 \\
124\end{array}$ & $\begin{array}{l}935.66 \\
947.12 \\
958.61 \\
970.11 \\
981.64\end{array}$ & $\begin{array}{l}11.456 \\
11.476 \\
11.496 \\
11.515 \\
11.535\end{array}$ & $\begin{array}{l}19.8 \\
19.8 \\
19.7 \\
19.7 \\
19.7\end{array}$ \\
\hline $\begin{array}{l}5 \\
6 \\
7 \\
8 \\
9\end{array}$ & $\begin{array}{r}-1.81 \\
-1.55 \\
-1.09 \\
-0.44 \\
0.40\end{array}$ & $\begin{array}{l}0.168 \\
0.360 \\
0.553 \\
0.747 \\
0.941\end{array}$ & $\begin{array}{l}192.5 \\
192.5 \\
193.0 \\
193.9 \\
195.0\end{array}$ & $\begin{array}{l}65 \\
66 \\
67 \\
68 \\
69\end{array}$ & $\begin{array}{l}341.23 \\
351.07 \\
360.97 \\
370.93 \\
380.95\end{array}$ & $\begin{array}{r}9.805 \\
9.869 \\
9.931 \\
9.991 \\
10.047\end{array}$ & $\begin{array}{l}66 \cdot 2 \\
63 \cdot 3 \\
60 \cdot 5 \\
57.8 \\
55 \cdot 3\end{array}$ & $\begin{array}{l}125 \\
126 \\
127 \\
128 \\
129\end{array}$ & $\begin{array}{r}993.18 \\
1004.75 \\
1016.33 \\
1027.94 \\
1039.56\end{array}$ & $\begin{array}{l}11.555 \\
11.574 \\
11.594 \\
11.613 \\
11.633\end{array}$ & $\begin{array}{l}19.6 \\
19.6 \\
19.5 \\
19.5 \\
19.5\end{array}$ \\
\hline $\begin{array}{l}10 \\
11 \\
12 \\
13 \\
14\end{array}$ & $\begin{array}{l}1.44 \\
2.68 \\
4.11 \\
5.74 \\
7.57\end{array}$ & $\begin{array}{l}1.137 \\
1.334 \\
1.532 \\
1.732 \\
1.933\end{array}$ & $\begin{array}{l}196.3 \\
197.7 \\
199.1 \\
200.5 \\
201.9\end{array}$ & $\begin{array}{l}70 \\
71 \\
72 \\
73 \\
74\end{array}$ & $\begin{array}{l}391 \cdot 03 \\
401.15 \\
411.33 \\
421.56 \\
431.83\end{array}$ & $\begin{array}{l}10.101 \\
10.153 \\
10.202 \\
10.250 \\
10.295\end{array}$ & $\begin{array}{l}52.9 \\
50.6 \\
48.4 \\
46.3 \\
44.3\end{array}$ & $\begin{array}{l}130 \\
131 \\
132 \\
133 \\
134\end{array}$ & $\begin{array}{l}1051.20 \\
1062.86 \\
1074.55 \\
1086.25 \\
1097.97\end{array}$ & $\begin{array}{l}11.652 \\
11.672 \\
11.691 \\
11.710 \\
11.730\end{array}$ & $\begin{array}{l}19.4 \\
19.4 \\
19.4 \\
19.3 \\
19.3\end{array}$ \\
\hline $\begin{array}{l}15 \\
16 \\
17 \\
18 \\
19\end{array}$ & $\begin{array}{r}9.61 \\
11.85 \\
14.29 \\
16.93 \\
19.79\end{array}$ & $\begin{array}{l}2.135 \\
2.339 \\
2.544 \\
2.750 \\
2.956\end{array}$ & $\begin{array}{l}203 \cdot 1 \\
204 \cdot 3 \\
205 \cdot 2 \\
206 \cdot 0 \\
206 \cdot 5\end{array}$ & $\begin{array}{l}75 \\
76 \\
77 \\
78 \\
79\end{array}$ & $\begin{array}{l}442.15 \\
452.50 \\
462.90 \\
473.34 \\
483.82\end{array}$ & $\begin{array}{l}10.338 \\
10.380 \\
10.419 \\
10.458 \\
10.494\end{array}$ & $\begin{array}{l}42.4 \\
40.6 \\
38.9 \\
37.4 \\
35.9\end{array}$ & $\begin{array}{l}135 \\
136 \\
137 \\
138 \\
139\end{array}$ & $\begin{array}{l}1109.71 \\
1121.46 \\
1133.24 \\
1145.04 \\
1156.86\end{array}$ & $\begin{array}{l}11.749 \\
11.768 \\
11.787 \\
11.807 \\
11.826\end{array}$ & $\begin{array}{l}19.3 \\
19.2 \\
19.2 \\
19.2 \\
19.2\end{array}$ \\
\hline $\begin{array}{l}20 \\
21 \\
22 \\
23 \\
24\end{array}$ & $\begin{array}{l}22.85 \\
26 \cdot 11 \\
29 \cdot 58 \\
33 \cdot 26 \\
37 \cdot 15\end{array}$ & $\begin{array}{l}3.162 \\
3.369 \\
3.576 \\
3.782 \\
3.988\end{array}$ & $\begin{array}{l}206 \cdot 8 \\
206 \cdot 8 \\
206 \cdot 6 \\
206 \cdot 2 \\
205 \cdot 4\end{array}$ & $\begin{array}{l}80 \\
81 \\
82 \\
83 \\
84\end{array}$ & $\begin{array}{l}494.33 \\
504.88 \\
515.46 \\
526.07 \\
536.71\end{array}$ & $\begin{array}{l}10.529 \\
10.563 \\
10.596 \\
10.627 \\
10.658\end{array}$ & $\begin{array}{l}34.5 \\
33.2 \\
32.0 \\
30.9 \\
29.8\end{array}$ & $\begin{array}{l}140 \\
141 \\
142 \\
143 \\
144\end{array}$ & $\begin{array}{l}1168.69 \\
1180.55 \\
1192.42 \\
1204.31 \\
1216.22\end{array}$ & $\begin{array}{l}11.845 \\
11.864 \\
11.883 \\
11.902 \\
11.922\end{array}$ & $\begin{array}{l}19 \cdot 2 \\
19 \cdot 1 \\
19 \cdot 1 \\
19 \cdot 1 \\
19.1\end{array}$ \\
\hline $\begin{array}{l}25 \\
26 \\
27 \\
28 \\
29\end{array}$ & $\begin{array}{l}41.24 \\
45.54 \\
50.03 \\
54.73 \\
5 c .63\end{array}$ & $\begin{array}{l}4.193 \\
4.397 \\
4.600 \\
4.800 \\
4.999\end{array}$ & $\begin{array}{l}204 \cdot 4 \\
203 \cdot 2 \\
201 \cdot 7 \\
199.9 \\
197 \cdot 9\end{array}$ & $\begin{array}{l}85 \\
86 \\
87 \\
88 \\
89\end{array}$ & $\begin{array}{l}547.38 \\
558.09 \\
568.81 \\
579.57 \\
590.35\end{array}$ & $\begin{array}{l}10.687 \\
10.715 \\
10.743 \\
10.770 \\
10.796\end{array}$ & $\begin{array}{l}28.9 \\
28.0 \\
27.2 \\
26.4 \\
25.7\end{array}$ & $\begin{array}{l}145 \\
146 \\
147 \\
148 \\
149\end{array}$ & $\begin{array}{l}1228.15 \\
1240.11 \\
1252.07 \\
1264.06 \\
1276.07\end{array}$ & $\begin{array}{l}11.941 \\
11.960 \\
11.979 \\
11.998 \\
12.017\end{array}$ & $\begin{array}{l}19.1 \\
19.2 \\
19.2 \\
19.2 \\
19.2\end{array}$ \\
\hline $\begin{array}{l}30 \\
31 \\
32 \\
33 \\
34\end{array}$ & $\begin{array}{l}64.73 \\
70.02 \\
75.51 \\
81.19 \\
87.05\end{array}$ & $\begin{array}{l}5.196 \\
5.390 \\
5.582 \\
5.771 \\
5.957\end{array}$ & $\begin{array}{l}195.6 \\
193 \cdot 2 \\
190.5 \\
187 \cdot 6 \\
184 \cdot 5\end{array}$ & $\begin{array}{l}90 \\
91 \\
92 \\
93 \\
94\end{array}$ & $\begin{array}{l}601.16 \\
612.00 \\
622.85 \\
633.74 \\
644.64\end{array}$ & $\begin{array}{l}10.821 \\
10.846 \\
10.870 \\
10.894 \\
10.917\end{array}$ & $\begin{array}{l}25.1 \\
24.5 \\
24.0 \\
23.5 \\
23.1\end{array}$ & $\begin{array}{l}150 \\
151 \\
152 \\
153 \\
154\end{array}$ & $\begin{array}{l}1288.10 \\
1300.14 \\
1312.21 \\
1324.29 \\
1336.40\end{array}$ & $\begin{array}{l}12.037 \\
12.056 \\
12.075 \\
12.094 \\
12.114\end{array}$ & $\begin{array}{l}19.2 \\
19.3 \\
19.3 \\
19.4 \\
19.4\end{array}$ \\
\hline $\begin{array}{l}35 \\
36 \\
37 \\
38 \\
39\end{array}$ & $\begin{array}{r}93 \cdot 10 \\
99 \cdot 33 \\
105 \cdot 74 \\
112 \cdot 32 \\
119 \cdot 08\end{array}$ & $\begin{array}{l}6.140 \\
6.320 \\
6.496 \\
6.669 \\
6.837\end{array}$ & $\begin{array}{l}181 \cdot 3 \\
177 \cdot 9 \\
174 \cdot 3 \\
170 \cdot 6 \\
166 \cdot 8\end{array}$ & $\begin{array}{l}95 \\
96 \\
97 \\
98 \\
99\end{array}$ & $\begin{array}{l}655.57 \\
666.52 \\
677.50 \\
688.49 \\
699.51\end{array}$ & $\begin{array}{l}10.940 \\
10.963 \\
10.985 \\
11.007 \\
11.029\end{array}$ & $\begin{array}{l}22 \cdot 7 \\
22 \cdot 4 \\
22 \cdot 1 \\
21 \cdot 8 \\
21.5\end{array}$ & $\begin{array}{l}155 \\
156 \\
157 \\
158 \\
159\end{array}$ & $\begin{array}{l}1348.52 \\
1360.66 \\
1372.83 \\
1385.01 \\
1397.21\end{array}$ & $\begin{array}{l}12 \cdot 133 \\
12.153 \\
12.172 \\
12 \cdot 192 \\
12.212\end{array}$ & $\begin{array}{l}19.5 \\
19.5 \\
19.6 \\
19.6 \\
19.7\end{array}$ \\
\hline $\begin{array}{l}40 \\
41 \\
42 \\
43 \\
44\end{array}$ & $\begin{array}{l}126 \cdot 00 \\
133.08 \\
140 \cdot 32 \\
147.72 \\
155.27\end{array}$ & $\begin{array}{l}7.002 \\
7.163 \\
7.320 \\
7.473 \\
7.621\end{array}$ & $\begin{array}{l}162.9 \\
158.9 \\
154 \cdot 8 \\
150.7 \\
146.5\end{array}$ & $\begin{array}{l}100 \\
101 \\
102 \\
103 \\
104\end{array}$ & $\begin{array}{l}710.55 \\
721.61 \\
732.69 \\
743.80 \\
754.92\end{array}$ & $\begin{array}{l}11.050 \\
11.071 \\
11.092 \\
11.113 \\
11.134\end{array}$ & $\begin{array}{l}21 \cdot 3 \\
21 \cdot 1 \\
21 \cdot 0 \\
20.8 \\
20.7\end{array}$ & $\begin{array}{l}160 \\
161 \\
162 \\
163 \\
164\end{array}$ & $\begin{array}{l}1409.43 \\
1421.67 \\
1433.93 \\
1446.22 \\
1458.52\end{array}$ & $\begin{array}{l}12 \cdot 231 \\
12 \cdot 251 \\
12 \cdot 271 \\
12 \cdot 291 \\
12.311\end{array}$ & $\begin{array}{l}19.7 \\
19.8 \\
19.9 \\
19.9 \\
20.0\end{array}$ \\
\hline $\begin{array}{l}45 \\
46 \\
47 \\
48 \\
49\end{array}$ & $\begin{array}{l}162 \cdot 96 \\
170 \cdot 80 \\
178 \cdot 77 \\
186.88 \\
195 \cdot 12\end{array}$ & $\begin{array}{l}7.766 \\
7.906 \\
8.042 \\
8.174 \\
8.301\end{array}$ & $\begin{array}{l}142 \cdot 3 \\
138 \cdot 1 \\
133.8 \\
129.6 \\
125.3\end{array}$ & $\begin{array}{l}105 \\
106 \\
107 \\
108 \\
109\end{array}$ & $\begin{array}{l}766.06 \\
777.23 \\
788.41 \\
799.62 \\
810.85\end{array}$ & $\begin{array}{l}11.155 \\
11.175 \\
11.196 \\
11.216 \\
11.236\end{array}$ & $\begin{array}{l}20.6 \\
20.5 \\
20.4 \\
20.3 \\
20.2\end{array}$ & $\begin{array}{l}165 \\
166 \\
167 \\
168 \\
169\end{array}$ & $\begin{array}{l}1470.84 \\
1483.18 \\
1495.54 \\
1507.92 \\
1520.32\end{array}$ & $\begin{array}{l}12 \cdot 331 \\
12 \cdot 351 \\
12 \cdot 371 \\
12 \cdot 391 \\
12.411\end{array}$ & $\begin{array}{l}20 \cdot 0 \\
20.1 \\
20 \cdot 1 \\
20.2 \\
20.2\end{array}$ \\
\hline $\begin{array}{l}50 \\
51 \\
52 \\
53 \\
54\end{array}$ & $\begin{array}{l}203 \cdot 48 \\
211.96 \\
220.56 \\
229 \cdot 28 \\
238.10\end{array}$ & $\begin{array}{l}8.424 \\
8.543 \\
8.658 \\
8.769 \\
8.876\end{array}$ & $\begin{array}{l}121 \cdot 1 \\
117 \cdot 0 \\
112.8 \\
108.7 \\
104.7\end{array}$ & $\begin{array}{ll}11 & 0 \\
1 & 11 \\
1112 \\
113 \\
114\end{array}$ & $\begin{array}{l}822.09 \\
833.36 \\
844.64 \\
855.95 \\
867.28\end{array}$ & $\begin{array}{l}11.256 \\
11.277 \\
11.297 \\
11.317 \\
11.337\end{array}$ & $\begin{array}{l}20.2 \\
20.1 \\
20.1 \\
20.0 \\
20.0\end{array}$ & $\begin{array}{l}170 \\
171 \\
172 \\
173 \\
174\end{array}$ & $\begin{array}{l}1532.74 \\
1545.18 \\
1557.65 \\
1570.13 \\
1582.63\end{array}$ & $\begin{array}{l}12.432 \\
12.452 \\
12.472 \\
12.493 \\
12.513\end{array}$ & $\begin{array}{l}20 \cdot 3 \\
20 \cdot 3 \\
20 \cdot 3 \\
20 \cdot 4 \\
20 \cdot 4\end{array}$ \\
\hline $\begin{array}{l}55 \\
56 \\
57 \\
58 \\
59\end{array}$ & $\begin{array}{l}247.03 \\
256.06 \\
265.18 \\
274.40 \\
283.71\end{array}$ & $\begin{array}{l}8.978 \\
9.077 \\
9.172 \\
9.263 \\
9.351\end{array}$ & $\begin{array}{r}100.8 \\
96.9 \\
93.1 \\
89.4 \\
85.7\end{array}$ & $\begin{array}{l}115 \\
116 \\
117 \\
118 \\
119\end{array}$ & $\begin{array}{l}878.62 \\
889.99 \\
901.38 \\
912.78 \\
924.21\end{array}$ & $\begin{array}{l}11.357 \\
11.377 \\
11.397 \\
11.416 \\
11.436\end{array}$ & $\begin{array}{l}20.0 \\
19.9 \\
19.9 \\
19.9 \\
19.8\end{array}$ & $\begin{array}{l}175 \\
176 \\
177 \\
178 \\
179\end{array}$ & $\begin{array}{l}1595.15 \\
1607.70 \\
1620.26 \\
1632.85 \\
1645.45\end{array}$ & $\begin{array}{l}12.533 \\
12.554 \\
12.574 \\
12.594 \\
12.615\end{array}$ & $\begin{array}{l}20 \cdot 4 \\
20 \cdot 4 \\
20 \cdot 3 \\
20 \cdot 3 \\
20 \cdot 3\end{array}$ \\
\hline 60 & 293.10 & 9.435 & 82.2 & 120 & 935.66 & 11.456 & 19.8 & 180 & 1658.08 & 12.635 & $20 \cdot 2$ \\
\hline
\end{tabular}




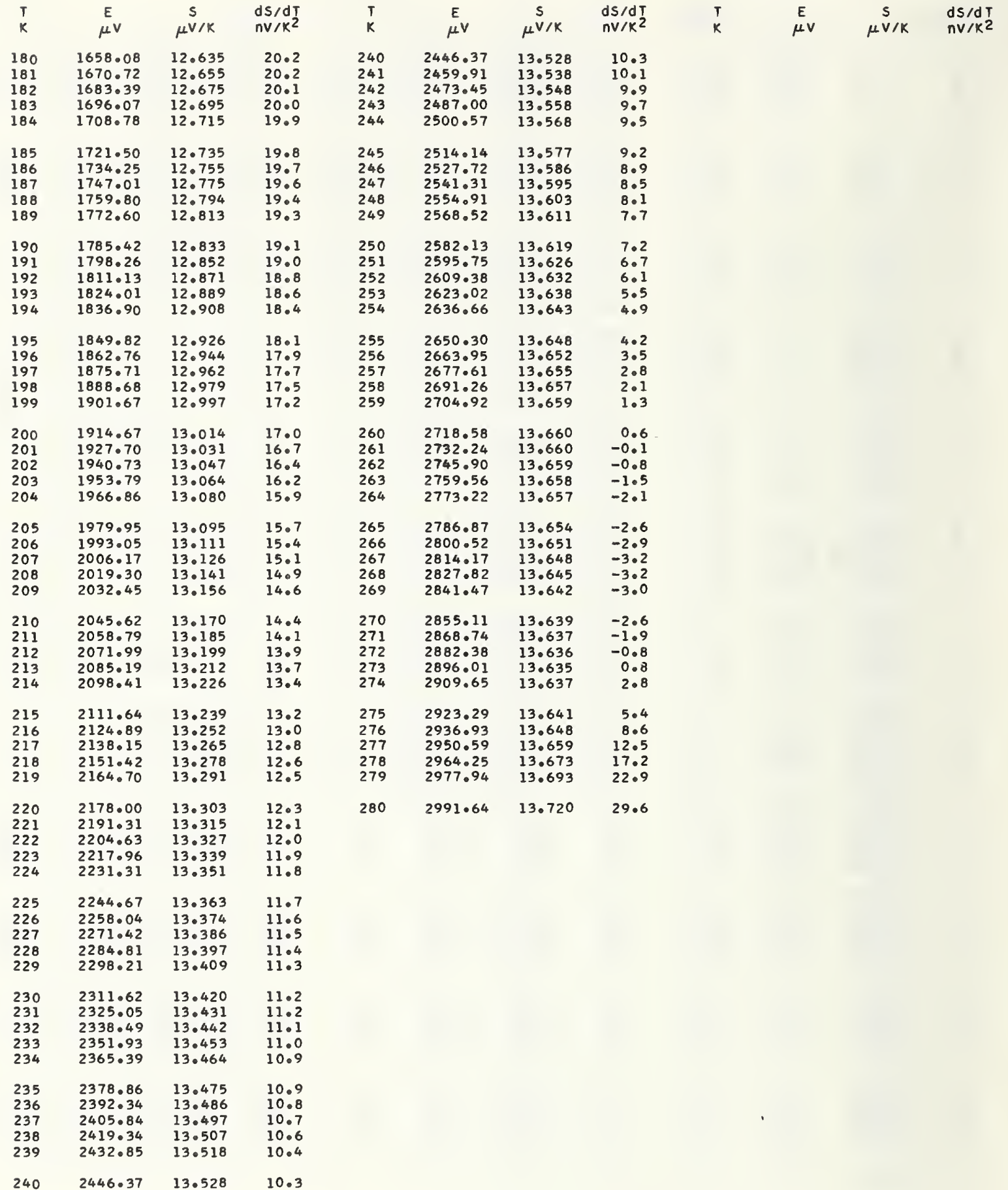




\begin{tabular}{|c|c|c|c|c|c|c|c|c|c|c|c|}
\hline $\begin{array}{l}T \\
K\end{array}$ & $\begin{array}{c}\mathrm{E} \\
\mu \mathrm{V}\end{array}$ & 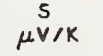 & $\begin{array}{l}d s / d T \\
n V / k^{2}\end{array}$ & $\begin{array}{l}T \\
K\end{array}$ & $\begin{array}{l}E \\
\mu V\end{array}$ & $\stackrel{S}{\mu \vee / K}$ & $\begin{array}{l}d s / d T \\
n v / K^{2}\end{array}$ & $\begin{array}{l}T \\
K\end{array}$ & ${ }_{\mu V}^{E}$ & $\mu_{\mathrm{S} / \mathrm{K}}^{\mathrm{S}}$ & $\begin{array}{l}d S / d T \\
n V / K 2\end{array}$ \\
\hline $\begin{array}{l}0 \\
1 \\
2 \\
3 \\
4\end{array}$ & $\begin{array}{r}1.39 \\
0.08 \\
-0.95 \\
-1.72 \\
-2.25\end{array}$ & $\begin{array}{l}-1.464 \\
-1.167 \\
-0.894 \\
-0.643 \\
-0.411\end{array}$ & $\begin{array}{l}310 \cdot 1 \\
284 \cdot 4 \\
261 \cdot 5 \\
241.1 \\
222.9\end{array}$ & $\begin{array}{l}60 \\
61 \\
62 \\
63 \\
64\end{array}$ & $\begin{array}{l}153.38 \\
157.86 \\
162.35 \\
166.84 \\
171.34\end{array}$ & $\begin{array}{l}4.480 \\
4.488 \\
4.492 \\
4.494 \\
4.493\end{array}$ & $\begin{array}{r}9.1 \\
6.2 \\
3.3 \\
0.5 \\
-2.2\end{array}$ & $\begin{array}{l}120 \\
121 \\
122 \\
123 \\
124\end{array}$ & $\begin{array}{l}366.96 \\
368.91 \\
370.80 \\
372.63 \\
374.39\end{array}$ & $\begin{array}{l}1.982 \\
1.920 \\
1.859 \\
1.797 \\
1.735\end{array}$ & $\begin{array}{l}-61.5 \\
-61.5 \\
-61.6 \\
-61.6 \\
-61.7\end{array}$ \\
\hline $\begin{array}{l}5 \\
6 \\
7 \\
8 \\
9\end{array}$ & $\begin{array}{l}-2.55 \\
-2.64 \\
-2.55 \\
-2.27 \\
-1.82\end{array}$ & $\begin{array}{r}-0.197 \\
0.003 \\
0.189 \\
0.363 \\
0.528\end{array}$ & $\begin{array}{l}206.8 \\
192.6 \\
180.1 \\
169.0 \\
159.3\end{array}$ & $\begin{array}{l}65 \\
66 \\
67 \\
68 \\
69\end{array}$ & $\begin{array}{l}175.83 \\
180.32 \\
184.80 \\
189.26 \\
193.72\end{array}$ & $\begin{array}{l}4.490 \\
4.484 \\
4.475 \\
4.463 \\
4.449\end{array}$ & $\begin{array}{r}-4.9 \\
-7 \cdot 6 \\
-10.1 \\
-12.6 \\
-15.1\end{array}$ & $\begin{array}{l}125 \\
126 \\
127 \\
128 \\
129\end{array}$ & $\begin{array}{l}376.10 \\
377.74 \\
379.32 \\
380.84 \\
382.30\end{array}$ & $\begin{array}{l}1.674 \\
1.612 \\
1.550 \\
1.488 \\
1.427\end{array}$ & $\begin{array}{l}-61 \cdot 7 \\
-61 \cdot 7 \\
-61 \cdot 8 \\
-61 \cdot 8 \\
-61.8\end{array}$ \\
\hline $\begin{array}{l}10 \\
11 \\
12 \\
13 \\
14\end{array}$ & $\begin{array}{r}-1.22 \\
-0.46 \\
0.44 \\
1.48 \\
2.64\end{array}$ & $\begin{array}{l}0.682 \\
0.829 \\
0.969 \\
1.103 \\
1.232\end{array}$ & $\begin{array}{l}150.8 \\
143.3 \\
136.8 \\
131.2 \\
126.2\end{array}$ & $\begin{array}{l}70 \\
71 \\
72 \\
73 \\
74\end{array}$ & $\begin{array}{l}198.16 \\
202.59 \\
206.99 \\
211.37 \\
215.73\end{array}$ & $\begin{array}{l}4.433 \\
4.415 \\
4.394 \\
4.371 \\
4.345\end{array}$ & $\begin{array}{l}-17.5 \\
-19.8 \\
-22.0 \\
-24.1 \\
-26.2\end{array}$ & $\begin{array}{l}130 \\
131 \\
132 \\
133 \\
134\end{array}$ & $\begin{array}{l}383.70 \\
385.03 \\
386.30 \\
387.51 \\
388.66\end{array}$ & $\begin{array}{l}1.365 \\
1.303 \\
1.241 \\
1.180 \\
1.118\end{array}$ & $\begin{array}{l}-61 \cdot 8 \\
-61 \cdot 8 \\
-61 \cdot 7 \\
-61 \cdot 7 \\
-61 \cdot 7\end{array}$ \\
\hline $\begin{array}{l}15 \\
16 \\
17 \\
18 \\
19\end{array}$ & $\begin{array}{r}3.94 \\
5.35 \\
6.89 \\
8.54 \\
10.30\end{array}$ & $\begin{array}{l}1.356 \\
1.476 \\
1.592 \\
1.706 \\
1.816\end{array}$ & $\begin{array}{l}121 \cdot 9 \\
118.1 \\
114.8 \\
111.9 \\
109.3\end{array}$ & $\begin{array}{l}75 \\
76 \\
77 \\
78 \\
79\end{array}$ & $\begin{array}{l}220.06 \\
224.37 \\
228.64 \\
232.88 \\
237.09\end{array}$ & $\begin{array}{l}4.318 \\
4.289 \\
4.258 \\
4.225 \\
4.190\end{array}$ & $\begin{array}{l}-28.2 \\
-30.2 \\
-32 \cdot 0 \\
-33.8 \\
-35.5\end{array}$ & $\begin{array}{l}135 \\
136 \\
137 \\
138 \\
139\end{array}$ & $\begin{array}{l}389.75 \\
390.77 \\
391.74 \\
392.64 \\
393.48\end{array}$ & $\begin{array}{l}1.056 \\
0.995 \\
0.933 \\
0.871 \\
0.810\end{array}$ & $\begin{array}{l}-61 \cdot 7 \\
-61 \cdot 6 \\
-61 \cdot 6 \\
-61 \cdot 5 \\
-61 \cdot 5\end{array}$ \\
\hline $\begin{array}{l}20 \\
21 \\
22 \\
23 \\
24\end{array}$ & $\begin{array}{l}12 \cdot 17 \\
14 \cdot 15 \\
16 \cdot 23 \\
18 \cdot 42 \\
20 \cdot 70\end{array}$ & $\begin{array}{l}1.924 \\
2.030 \\
2.134 \\
2.236 \\
2.336\end{array}$ & $\begin{array}{r}106 \cdot 9 \\
104 \cdot 8 \\
102.9 \\
101 \cdot 1 \\
99 \cdot 3\end{array}$ & $\begin{array}{l}80 \\
81 \\
82 \\
83 \\
84\end{array}$ & $\begin{array}{l}241.26 \\
245.40 \\
249.49 \\
253.55 \\
257.56\end{array}$ & $\begin{array}{l}4.154 \\
4.116 \\
4.077 \\
4.036 \\
3.993\end{array}$ & $\begin{array}{l}-37 \cdot 2 \\
-38.7 \\
-40.2 \\
-41.6 \\
-43.0\end{array}$ & $\begin{array}{l}140 \\
141 \\
142 \\
143 \\
144\end{array}$ & $\begin{array}{l}394.26 \\
394.98 \\
395.63 \\
396.23 \\
396.76\end{array}$ & $\begin{array}{l}0.748 \\
0.687 \\
0.626 \\
0.565 \\
0.504\end{array}$ & $\begin{array}{l}-61 \cdot 4 \\
-61 \cdot 3 \\
-61 \cdot 2 \\
-61 \cdot 1 \\
-61 \cdot 0\end{array}$ \\
\hline $\begin{array}{l}25 \\
26 \\
27 \\
28 \\
29\end{array}$ & $\begin{array}{l}23.09 \\
25.57 \\
28.15 \\
30.82 \\
33.59\end{array}$ & $\begin{array}{l}2.435 \\
2.531 \\
2.627 \\
2.720 \\
2.812\end{array}$ & $\begin{array}{l}97.7 \\
96.0 \\
94.4 \\
92.8 \\
91.1\end{array}$ & $\begin{array}{l}85 \\
86 \\
87 \\
88 \\
89\end{array}$ & $\begin{array}{l}261.54 \\
265.46 \\
269.35 \\
273.18 \\
276.97\end{array}$ & $\begin{array}{l}3.950 \\
3.905 \\
3.859 \\
3.811 \\
3.763\end{array}$ & $\begin{array}{l}-44.3 \\
-45.5 \\
-46.7 \\
-47.8 \\
-48.8\end{array}$ & $\begin{array}{l}145 \\
146 \\
147 \\
148 \\
149\end{array}$ & $\begin{array}{l}397.24 \\
397.65 \\
398.00 \\
398.29 \\
398.52\end{array}$ & $\begin{array}{l}0.443 \\
0.382 \\
0.321 \\
0.260 \\
0.200\end{array}$ & $\begin{array}{l}-60.9 \\
-60.8 \\
-60.7 \\
-60.6 \\
-60.5\end{array}$ \\
\hline $\begin{array}{l}30 \\
31 \\
32 \\
33 \\
34\end{array}$ & $\begin{array}{l}36 \cdot 45 \\
39 \cdot 39 \\
42.43 \\
45 \cdot 55 \\
48.75\end{array}$ & $\begin{array}{l}2.902 \\
2.991 \\
3.078 \\
3.162 \\
3.245\end{array}$ & $\begin{array}{l}89.4 \\
87.6 \\
85.8 \\
83.8 \\
81.8\end{array}$ & $\begin{array}{l}90 \\
91 \\
92 \\
93 \\
94\end{array}$ & $\begin{array}{l}280.71 \\
284.39 \\
288.03 \\
291.62 \\
295.15\end{array}$ & $\begin{array}{l}3.714 \\
3.664 \\
3.612 \\
3.561 \\
3.508\end{array}$ & $\begin{array}{l}-49.8 \\
-50.7 \\
-51.6 \\
-52.4 \\
-53.1\end{array}$ & $\begin{array}{l}150 \\
151 \\
152 \\
153 \\
154\end{array}$ & $\begin{array}{l}398.69 \\
398.80 \\
398.85 \\
398.84 \\
398.77\end{array}$ & $\begin{array}{r}0.139 \\
0.079 \\
0.019 \\
-0.041 \\
-0.101\end{array}$ & $\begin{array}{l}-60.3 \\
-60.2 \\
-60.0 \\
-59.9 \\
-59.7\end{array}$ \\
\hline $\begin{array}{l}35 \\
36 \\
37 \\
38 \\
39\end{array}$ & $\begin{array}{l}52 \cdot 04 \\
55 \cdot 40 \\
58 \cdot 85 \\
62 \cdot 37 \\
65.96\end{array}$ & $\begin{array}{l}3.326 \\
3.405 \\
3.481 \\
3.555 \\
3.627\end{array}$ & $\begin{array}{l}79.7 \\
77.6 \\
75.3 \\
73.0 \\
70.5\end{array}$ & $\begin{array}{l}95 \\
96 \\
97 \\
98 \\
99\end{array}$ & $\begin{array}{l}298.63 \\
302.06 \\
305.43 \\
308.75 \\
312.01\end{array}$ & $\begin{array}{l}3.454 \\
3.400 \\
3.345 \\
3.290 \\
3.234\end{array}$ & $\begin{array}{l}-53.8 \\
-54 \cdot 5 \\
-55 \cdot 1 \\
-55.7 \\
-56.3\end{array}$ & $\begin{array}{l}155 \\
156 \\
157 \\
158 \\
159\end{array}$ & $\begin{array}{l}398.63 \\
398.44 \\
398.20 \\
397.89 \\
397.52\end{array}$ & $\begin{array}{l}-0.160 \\
-0.220 \\
-0.279 \\
-0.338 \\
-0.397\end{array}$ & $\begin{array}{l}-59.5 \\
-59.4 \\
-59.2 \\
-59.0 \\
-58.8\end{array}$ \\
\hline $\begin{array}{l}40 \\
41 \\
42 \\
43 \\
44\end{array}$ & $\begin{array}{l}69 \cdot 62 \\
73 \cdot 35 \\
77 \cdot 14 \\
81 \cdot 00 \\
84.92\end{array}$ & $\begin{array}{l}3.696 \\
3.763 \\
3.827 \\
3.889 \\
3.947\end{array}$ & $\begin{array}{l}68.0 \\
65.4 \\
62.8 \\
60.0 \\
57.2\end{array}$ & $\begin{array}{l}100 \\
101 \\
102 \\
103 \\
104\end{array}$ & $\begin{array}{l}315.22 \\
318.37 \\
321.46 \\
324.49 \\
327.47\end{array}$ & $\begin{array}{l}3.177 \\
3.120 \\
3.063 \\
3.005 \\
2.947\end{array}$ & $\begin{array}{l}-56.8 \\
-57.2 \\
-57.7 \\
-58.1 \\
-58.4\end{array}$ & $\begin{array}{l}160 \\
161 \\
162 \\
163 \\
164\end{array}$ & $\begin{array}{l}397.09 \\
396.61 \\
396.06 \\
395.46 \\
394.80\end{array}$ & $\begin{array}{l}-0.456 \\
-0.514 \\
-0.573 \\
-0.631 \\
-0.689\end{array}$ & $\begin{array}{l}-58.6 \\
-58.4 \\
-58.2 \\
-58.0 \\
-57.8\end{array}$ \\
\hline $\begin{array}{l}45 \\
46 \\
47 \\
48 \\
49\end{array}$ & $\begin{array}{r}88.90 \\
92.93 \\
97.01 \\
101.14 \\
105.31\end{array}$ & $\begin{array}{l}4.003 \\
4.056 \\
4.106 \\
4.153 \\
4.197\end{array}$ & $\begin{array}{l}54 \cdot 4 \\
51 \cdot 5 \\
48 \cdot 5 \\
45 \cdot 5 \\
42 \cdot 5\end{array}$ & $\begin{array}{l}105 \\
106 \\
107 \\
108 \\
109\end{array}$ & $\begin{array}{l}330.39 \\
333.25 \\
336.05 \\
338.79 \\
341.47\end{array}$ & $\begin{array}{l}2.888 \\
2.829 \\
2.770 \\
2.710 \\
2.651\end{array}$ & $\begin{array}{l}-58.8 \\
-59.1 \\
-59.4 \\
-59.6 \\
-59.9\end{array}$ & $\begin{array}{l}165 \\
166 \\
167 \\
168 \\
169\end{array}$ & $\begin{array}{l}394.09 \\
393.31 \\
392.48 \\
391.59 \\
390.64\end{array}$ & $\begin{array}{l}-0.746 \\
-0.804 \\
-0.861 \\
-0.918 \\
-0.975\end{array}$ & $\begin{array}{l}-57.6 \\
-57.3 \\
-57.1 \\
-56.9 \\
-56.7\end{array}$ \\
\hline $\begin{array}{l}50 \\
51 \\
52 \\
53 \\
54\end{array}$ & $\begin{array}{l}109.53 \\
113.79 \\
118.08 \\
122.41 \\
126.77\end{array}$ & $\begin{array}{l}4.238 \\
4.276 \\
4.311 \\
4.343 \\
4.372\end{array}$ & $\begin{array}{l}39.5 \\
36.4 \\
33.3 \\
30.3 \\
27.2\end{array}$ & $\begin{array}{l}110 \\
111 \\
112 \\
113 \\
114\end{array}$ & $\begin{array}{l}344.09 \\
346.65 \\
349.15 \\
351.59 \\
353.97\end{array}$ & $\begin{array}{l}2.591 \\
2.530 \\
2.470 \\
2.409 \\
2.349\end{array}$ & $\begin{array}{l}-60.1 \\
-60.3 \\
-60.5 \\
-60.7 \\
-60.8\end{array}$ & $\begin{array}{l}170 \\
171 \\
172 \\
173 \\
174\end{array}$ & $\begin{array}{l}389.64 \\
388.58 \\
387.47 \\
386.29 \\
385.07\end{array}$ & $\begin{array}{l}-1.031 \\
-1.087 \\
-1.144 \\
-1.199 \\
-1.255\end{array}$ & $\begin{array}{l}-56 \cdot 4 \\
-56 \cdot 2 \\
-56 \cdot 0 \\
-55 \cdot 7 \\
-55 \cdot 5\end{array}$ \\
\hline $\begin{array}{l}55 \\
56 \\
57 \\
58 \\
59\end{array}$ & $\begin{array}{l}131.15 \\
135.56 \\
139.99 \\
144.44 \\
148.90\end{array}$ & $\begin{array}{l}4.397 \\
4.420 \\
4.439 \\
4.456 \\
4.469\end{array}$ & $\begin{array}{l}24.1 \\
21.1 \\
18.0 \\
15.0 \\
12.0\end{array}$ & $\begin{array}{l}115 \\
116 \\
117 \\
118 \\
119\end{array}$ & $\begin{array}{l}356.29 \\
358.54 \\
360.74 \\
362.87 \\
364.95\end{array}$ & $\begin{array}{l}2.288 \\
2.227 \\
2.166 \\
2.104 \\
2.043\end{array}$ & $\begin{array}{l}-61 \cdot 0 \\
-61 \cdot 1 \\
-61 \cdot 2 \\
-61 \cdot 3 \\
-61 \cdot 4\end{array}$ & $\begin{array}{l}175 \\
176 \\
177 \\
178 \\
179\end{array}$ & $\begin{array}{l}383.78 \\
382.45 \\
381.05 \\
379.60 \\
378.10\end{array}$ & $\begin{array}{l}-1.310 \\
-1.366 \\
-1.421 \\
-1.475 \\
-1.530\end{array}$ & $\begin{array}{l}-55 \cdot 3 \\
-55 \cdot 1 \\
-54 \cdot 8 \\
-54 \cdot 6 \\
-54 \cdot 4\end{array}$ \\
\hline 60 & 153.38 & 4.480 & 9.1 & 120 & 366.96 & 1.982 & -61.5 & 180 & 376.55 & -1.584 & $-54 \cdot 2$ \\
\hline
\end{tabular}




\begin{tabular}{|c|c|c|c|c|c|c|c|c|c|c|c|}
\hline $\begin{array}{l}T \\
k\end{array}$ & $\begin{array}{c}E \\
\mu v\end{array}$ & $\stackrel{S}{\mu V / K}$ & $\begin{array}{l}d s / d T \\
n V / K^{2}\end{array}$ & $\begin{array}{l}T \\
K\end{array}$ & $\begin{array}{c}E \\
\mu V\end{array}$ & $\stackrel{s}{\mu v / K}$ & $\begin{array}{l}\mathrm{ds} / \mathrm{dT} \\
\mathrm{nV} / \mathrm{K}^{2}\end{array}$ & $\begin{array}{l}T \\
K\end{array}$ & $\begin{array}{l}E \\
\mu V\end{array}$ & $\begin{array}{c}\mathrm{S} \\
\mu \mathrm{V} / \mathrm{K}\end{array}$ & $\begin{array}{l}d s / d T \\
n v / k^{2}\end{array}$ \\
\hline $\begin{array}{l}180 \\
181 \\
182 \\
183 \\
184\end{array}$ & $\begin{array}{l}376.55 \\
374.93 \\
373.27 \\
371.55 \\
369.78\end{array}$ & $\begin{array}{l}-1.584 \\
-1.638 \\
-1.692 \\
-1.746 \\
-1.799\end{array}$ & $\begin{array}{l}-54.2 \\
-54.0 \\
-53.7 \\
-53.5 \\
-53.3\end{array}$ & $\begin{array}{l}240 \\
241 \\
242 \\
243 \\
244\end{array}$ & $\begin{array}{l}190.20 \\
185.65 \\
181.07 \\
176.44 \\
171.77\end{array}$ & $\begin{array}{l}-4.523 \\
-4.566 \\
-4.609 \\
-4.651 \\
-4.693\end{array}$ & $\begin{array}{l}-42 \cdot 9 \\
-42.7 \\
-42.5 \\
-42.3 \\
-42.2\end{array}$ & & & & \\
\hline $\begin{array}{l}185 \\
186 \\
187 \\
188 \\
189\end{array}$ & $\begin{array}{l}367.95 \\
366.07 \\
364.14 \\
362.16 \\
360.12\end{array}$ & $\begin{array}{l}-1.852 \\
-1.905 \\
-1.958 \\
-2.011 \\
-2.063\end{array}$ & $\begin{array}{l}-53.1 \\
-52.9 \\
-52.7 \\
-52.6 \\
-52.4\end{array}$ & $\begin{array}{l}245 \\
246 \\
247 \\
248 \\
249\end{array}$ & $\begin{array}{l}167.05 \\
162.29 \\
157.50 \\
152.66 \\
147.77\end{array}$ & $\begin{array}{l}-4.735 \\
-4.777 \\
-4.819 \\
-4.861 \\
-4.902\end{array}$ & $\begin{array}{l}-42.0 \\
-41.9 \\
-41.7 \\
-41.6 \\
-41.6\end{array}$ & & & & \\
\hline $\begin{array}{l}190 \\
191 \\
192 \\
193 \\
194\end{array}$ & $\begin{array}{l}358.03 \\
355.89 \\
353.70 \\
351.45 \\
349.15\end{array}$ & $\begin{array}{l}-2.116 \\
-2.168 \\
-2.220 \\
-2.271 \\
-2.323\end{array}$ & $\begin{array}{l}-52.2 \\
-52.0 \\
-51.9 \\
-51.7 \\
-51.5\end{array}$ & $\begin{array}{l}250 \\
251 \\
252 \\
253 \\
254\end{array}$ & $\begin{array}{l}142.85 \\
137.89 \\
132.88 \\
127.83 \\
122.74\end{array}$ & $\begin{array}{l}-4.944 \\
-4.985 \\
-5.027 \\
-5.068 \\
-5.110\end{array}$ & $\begin{array}{l}-41 \cdot 5 \\
-41 \cdot 5 \\
-41 \cdot 5 \\
-41 \cdot 5 \\
-41.5\end{array}$ & & & & \\
\hline $\begin{array}{l}195 \\
196 \\
197 \\
198 \\
199\end{array}$ & $\begin{array}{l}346 \cdot 80 \\
344 \cdot 40 \\
341.95 \\
339 \cdot 45 \\
336 \cdot 90\end{array}$ & $\begin{array}{l}-2.374 \\
-2.426 \\
-2.477 \\
-2.528 \\
-2.579\end{array}$ & $\begin{array}{l}-51.4 \\
-51.2 \\
-51.1 \\
-51.0 \\
-50.8\end{array}$ & $\begin{array}{l}255 \\
256 \\
257 \\
258 \\
259\end{array}$ & $\begin{array}{r}117.61 \\
112.44 \\
107.23 \\
101.97 \\
96.68\end{array}$ & $\begin{array}{l}-5.151 \\
-5.193 \\
-5.235 \\
-5.276 \\
-5.318\end{array}$ & $\begin{array}{l}-41.6 \\
-41.6 \\
-41.7 \\
-41.8 \\
-41.9\end{array}$ & & & & \\
\hline $\begin{array}{l}200 \\
201 \\
202 \\
203 \\
204\end{array}$ & $\begin{array}{l}334.29 \\
331.64 \\
328.93 \\
326.18 \\
323.37\end{array}$ & $\begin{array}{l}-2.630 \\
-2.680 \\
-2.731 \\
-2.781 \\
-2.831\end{array}$ & $\begin{array}{l}-50.7 \\
-50.5 \\
-50.4 \\
-50.3 \\
-50.1\end{array}$ & $\begin{array}{l}260 \\
261 \\
262 \\
263 \\
264\end{array}$ & $\begin{array}{l}91.34 \\
85.96 \\
80.53 \\
75.07 \\
69.56\end{array}$ & $\begin{array}{l}-5.360 \\
-5.402 \\
-5.444 \\
-5.487 \\
-5.529\end{array}$ & $\begin{array}{l}-42 \cdot 0 \\
-42 \cdot 1 \\
-42 \cdot 2 \\
-42 \cdot 2 \\
-42 \cdot 2\end{array}$ & & & & \\
\hline $\begin{array}{l}205 \\
206 \\
207 \\
208 \\
209\end{array}$ & $\begin{array}{l}320.51 \\
317.61 \\
314.65 \\
311.65 \\
308.59\end{array}$ & $\begin{array}{l}-2.881 \\
-2.931 \\
-2.981 \\
-3.031 \\
-3.080\end{array}$ & $\begin{array}{l}-50.0 \\
-49.9 \\
-49.7 \\
-49.6 \\
-49.5\end{array}$ & $\begin{array}{l}265 \\
266 \\
267 \\
268 \\
269\end{array}$ & $\begin{array}{l}64.01 \\
58.42 \\
52.78 \\
47.11 \\
41.39\end{array}$ & $\begin{array}{l}-5.571 \\
-5.613 \\
-5.655 \\
-5.697 \\
-5.738\end{array}$ & $\begin{array}{l}-42.2 \\
-42.1 \\
-41.9 \\
-41.6 \\
-41.1\end{array}$ & & & & \\
\hline $\begin{array}{l}210 \\
211 \\
212 \\
213 \\
214\end{array}$ & $\begin{array}{l}305.49 \\
302.33 \\
299.13 \\
295.87 \\
292.57\end{array}$ & $\begin{array}{l}-3.130 \\
-3.179 \\
-3.228 \\
-3.277 \\
-3.326\end{array}$ & $\begin{array}{l}-49.3 \\
-49.2 \\
-49.0 \\
-48.9 \\
-48.7\end{array}$ & $\begin{array}{l}270 \\
271 \\
272 \\
273 \\
274\end{array}$ & $\begin{array}{l}35.63 \\
29.83 \\
23.99 \\
18.11 \\
12.20\end{array}$ & $\begin{array}{l}-5.779 \\
-5.819 \\
-5.859 \\
-5.897 \\
-5.934\end{array}$ & $\begin{array}{l}-40.6 \\
-39.8 \\
-38.8 \\
-37.6 \\
-36.1\end{array}$ & & & & \\
\hline $\begin{array}{l}215 \\
216 \\
217 \\
218 \\
219\end{array}$ & $\begin{array}{l}289.22 \\
285.82 \\
282.38 \\
278.88 \\
275.34\end{array}$ & $\begin{array}{l}-3.375 \\
-3.423 \\
-3.471 \\
-3.520 \\
-3.568\end{array}$ & $\begin{array}{l}-48 \cdot 6 \\
-48 \cdot 4 \\
-48 \cdot 2 \\
-48 \cdot 1 \\
-47.9\end{array}$ & $\begin{array}{l}275 \\
276 \\
277 \\
278 \\
279\end{array}$ & $\begin{array}{r}6.25 \\
0.26 \\
-5.76 \\
-11.80 \\
-17.88\end{array}$ & $\begin{array}{l}-5.969 \\
-6.002 \\
-6.033 \\
-6.061 \\
-6.085\end{array}$ & $\begin{array}{l}-34 \cdot 3 \\
-32.0 \\
-29 \cdot 4 \\
-26 \cdot 3 \\
-22.6\end{array}$ & & & & \\
\hline $\begin{array}{l}220 \\
221 \\
222 \\
223 \\
224\end{array}$ & $\begin{array}{l}271.75 \\
268.11 \\
264.42 \\
260.69 \\
256.91\end{array}$ & $\begin{array}{l}-3.615 \\
-3.663 \\
-3.710 \\
-3.758 \\
-3.804\end{array}$ & $\begin{array}{l}-47.7 \\
-47.5 \\
-47.3 \\
-47.1 \\
-46.9\end{array}$ & 280 & -23.97 & -6.106 & $-18 \cdot 3$ & & & & \\
\hline $\begin{array}{l}225 \\
226 \\
227 \\
228 \\
229\end{array}$ & $\begin{array}{l}253.08 \\
249.20 \\
245.28 \\
241.32 \\
237.30\end{array}$ & $\begin{array}{l}-3.851 \\
-3.898 \\
-3.944 \\
-3.990 \\
-4.036\end{array}$ & $\begin{array}{l}-46.6 \\
-46.4 \\
-46.2 \\
-45.9 \\
-45.7\end{array}$ & & & & & & & & \\
\hline $\begin{array}{l}230 \\
231 \\
232 \\
233 \\
234\end{array}$ & $\begin{array}{l}233 \cdot 24 \\
229 \cdot 14 \\
224 \cdot 99 \\
220.80 \\
216.56\end{array}$ & $\begin{array}{l}-4.082 \\
-4.127 \\
-4.172 \\
-4.217 \\
-4.261\end{array}$ & $\begin{array}{l}-45 \cdot 4 \\
-45 \cdot 2 \\
-44 \cdot 9 \\
-44 \cdot 7 \\
-44.4\end{array}$ & & & & & & & & \\
\hline $\begin{array}{l}235 \\
236 \\
237 \\
238 \\
239\end{array}$ & $\begin{array}{l}212.27 \\
207.95 \\
203.57 \\
199.16 \\
194.70\end{array}$ & $\begin{array}{l}-4 \cdot 305 \\
-4 \cdot 350 \\
-4 \cdot 393 \\
-4.437 \\
-4.480\end{array}$ & $\begin{array}{l}-44 \cdot 2 \\
-43 \cdot 9 \\
-43 \cdot 7 \\
-43.4 \\
-43.2\end{array}$ & & & & & & . & & \\
\hline 240 & $190 \cdot 20$ & -4.523 & $-42 \cdot 9$ & & & & & & & & \\
\hline
\end{tabular}




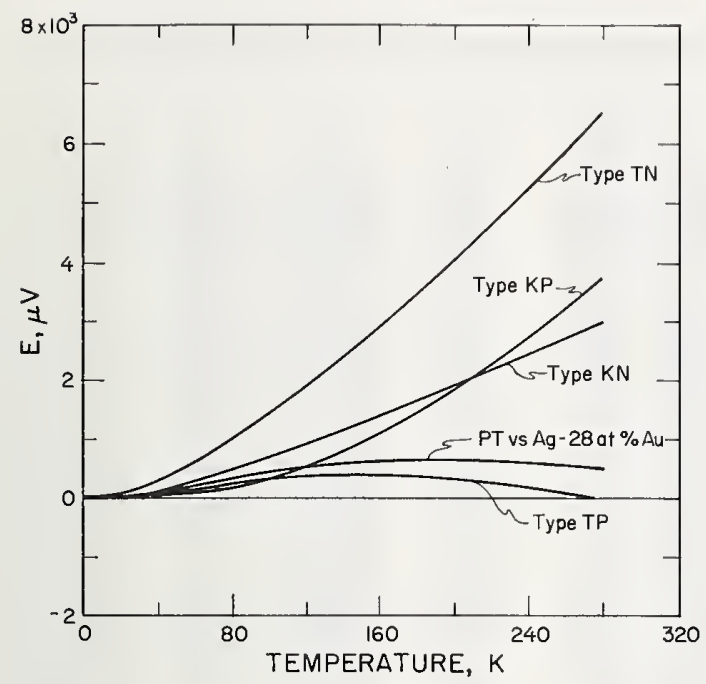

FiguRE 15. Thermoelectric voltage for thermocouple materials versus $P t$.

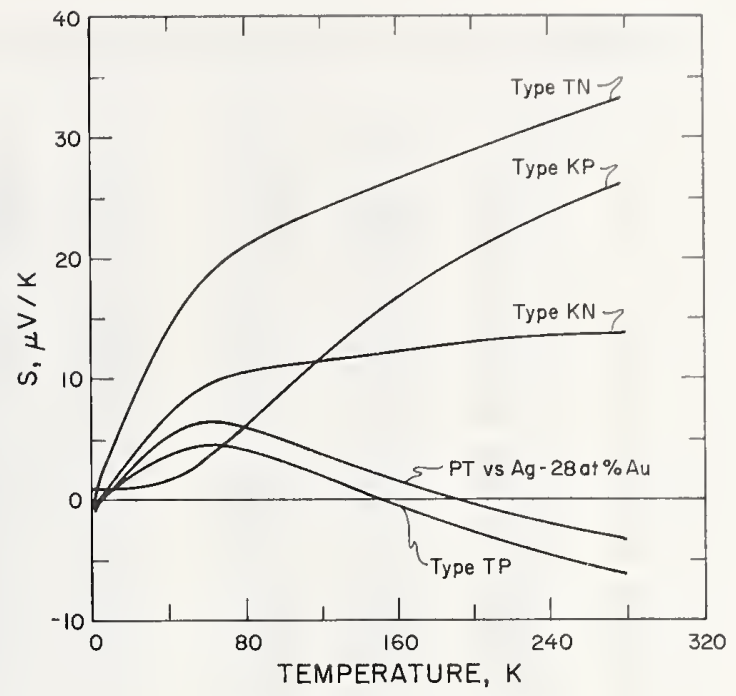

Figure 16. Seebeck coefficient for thermocouple materials versus $P t$. 


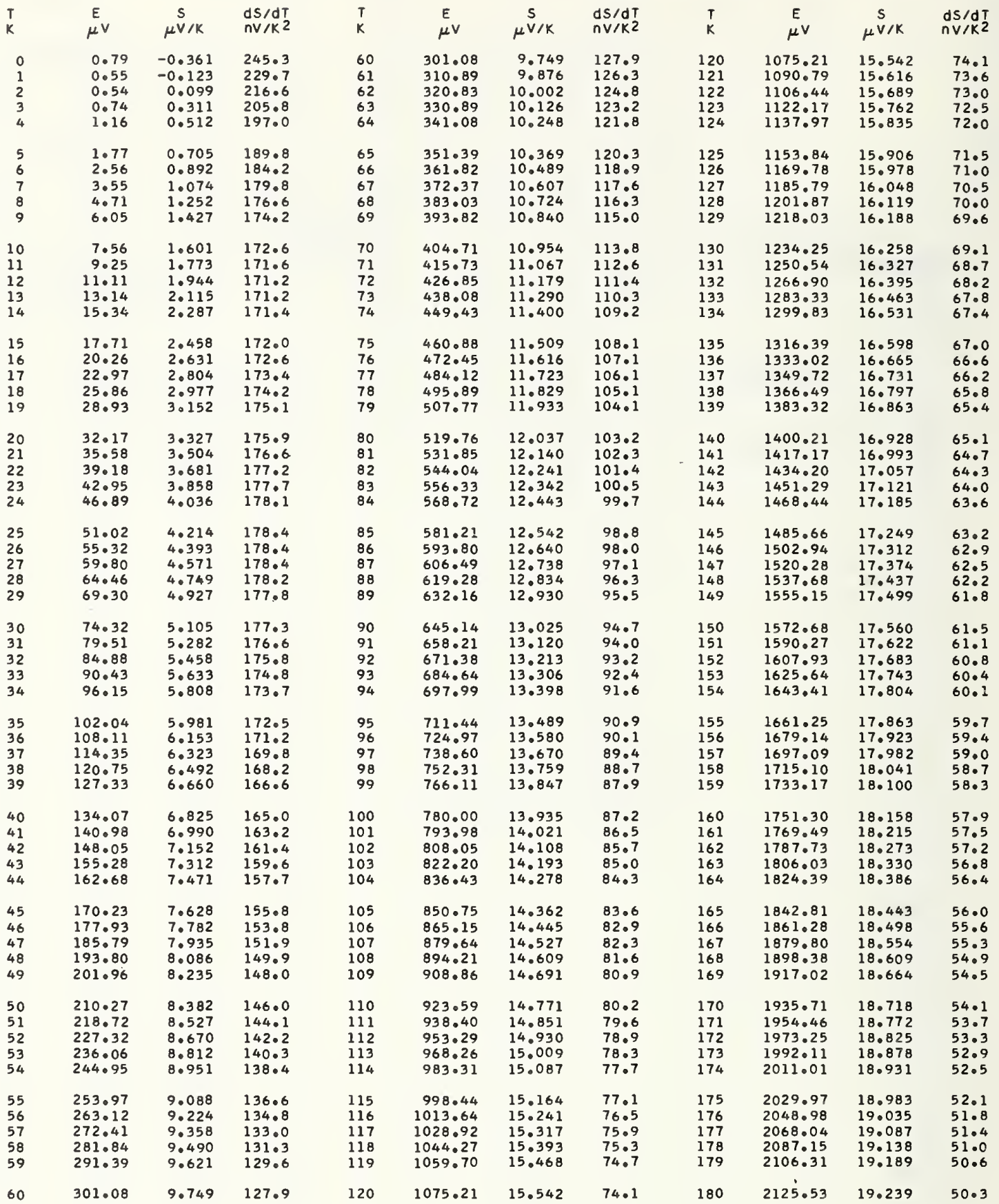




\begin{tabular}{|c|c|c|c|c|c|c|c|c|c|c|c|}
\hline $\begin{array}{l}T \\
k\end{array}$ & $\begin{array}{l}E \\
\mu V\end{array}$ & $\stackrel{5}{\mu V / K}$ & $\begin{array}{l}d s / d T \\
n V / K^{2}\end{array}$ & $\begin{array}{l}T \\
K\end{array}$ & $\begin{array}{c}E \\
\mu V\end{array}$ & $\stackrel{s}{s v / k}$ & $\begin{array}{l}d s / d T \\
n V / K^{2}\end{array}$ & $\begin{array}{l}T \\
k\end{array}$ & $\begin{array}{l}E \\
\mu V\end{array}$ & $\stackrel{S}{S}$ & $\begin{array}{l}d s / d T \\
n V / k^{2}\end{array}$ \\
\hline $\begin{array}{l}180 \\
181 \\
182 \\
183 \\
184\end{array}$ & $\begin{array}{l}2125.53 \\
2144.79 \\
2164.11 \\
2183.47 \\
2202.88\end{array}$ & $\begin{array}{l}19.239 \\
19.289 \\
19.339 \\
19.389 \\
19.438\end{array}$ & $\begin{array}{l}50.3 \\
49.9 \\
49.5 \\
49.2 \\
48.9\end{array}$ & $\begin{array}{l}240 \\
241 \\
242 \\
243 \\
244\end{array}$ & $\begin{array}{l}3360 \cdot 75 \\
3382 \cdot 55 \\
3404 \cdot 38 \\
3426 \cdot 25 \\
3448.14\end{array}$ & $\begin{array}{l}21.783 \\
21.815 \\
21.848 \\
21.880 \\
21.912\end{array}$ & $\begin{array}{l}33.0 \\
32.6 \\
32.2 \\
31.9 \\
31.6\end{array}$ & & & & \\
\hline $\begin{array}{l}185 \\
186 \\
187 \\
188 \\
189\end{array}$ & $\begin{array}{l}2222.35 \\
2241.86 \\
2261.42 \\
2281.02 \\
2300.68\end{array}$ & $\begin{array}{l}19.486 \\
19.535 \\
19.583 \\
19.630 \\
19.678\end{array}$ & $\begin{array}{l}48.5 \\
48.2 \\
47.9 \\
47.6 \\
47.3\end{array}$ & $\begin{array}{l}245 \\
246 \\
247 \\
248 \\
249\end{array}$ & $\begin{array}{l}3470.07 \\
3492.03 \\
3514.02 \\
3536.04 \\
3558.09\end{array}$ & $\begin{array}{l}21.943 \\
21.974 \\
22.005 \\
22.036 \\
22.067\end{array}$ & $\begin{array}{l}31.4 \\
31.2 \\
31.0 \\
30.9 \\
30.8\end{array}$ & & & & \\
\hline $\begin{array}{l}190 \\
191 \\
192 \\
193 \\
194\end{array}$ & $\begin{array}{l}2320.38 \\
2340.13 \\
2359 \cdot 92 \\
2379.76 \\
2399.65\end{array}$ & $\begin{array}{l}19.725 \\
19.772 \\
19.818 \\
19.865 \\
19.911\end{array}$ & $\begin{array}{l}47.0 \\
46.7 \\
46.4 \\
46.2 \\
45.9\end{array}$ & $\begin{array}{l}250 \\
251 \\
252 \\
253 \\
254\end{array}$ & $\begin{array}{l}3580.18 \\
3602.29 \\
3624.43 \\
3646.61 \\
3668.82\end{array}$ & $\begin{array}{l}22.098 \\
22.129 \\
22.160 \\
22.191 \\
22.222\end{array}$ & $\begin{array}{l}30.8 \\
30.9 \\
31.0 \\
31.2 \\
31.4\end{array}$ & & & & \\
\hline $\begin{array}{l}195 \\
196 \\
197 \\
198 \\
199\end{array}$ & $\begin{array}{l}2419.58 \\
2439.56 \\
2459.59 \\
2479.66 \\
2499.77\end{array}$ & $\begin{array}{l}19.956 \\
20.002 \\
20.047 \\
20.093 \\
20.137\end{array}$ & $\begin{array}{l}45 \cdot 7 \\
45.5 \\
45.2 \\
45.0 \\
44.8\end{array}$ & $\begin{array}{l}255 \\
256 \\
257 \\
258 \\
259\end{array}$ & $\begin{array}{l}3691.05 \\
3713.32 \\
3735.62 \\
3757.96 \\
3780.32\end{array}$ & $\begin{array}{l}22.254 \\
22 \cdot 285 \\
22.318 \\
22.350 \\
22.383\end{array}$ & $\begin{array}{l}31.7 \\
32.0 \\
32.4 \\
32.8 \\
33.2\end{array}$ & & & & \\
\hline $\begin{array}{l}200 \\
201 \\
202 \\
203 \\
204\end{array}$ & $\begin{array}{l}2519.93 \\
2540.14 \\
2560.39 \\
2580.68 \\
2601.02\end{array}$ & $\begin{array}{l}20.182 \\
20.227 \\
20.271 \\
20.315 \\
20.359\end{array}$ & $\begin{array}{l}44.6 \\
44.4 \\
44.3 \\
44.1 \\
43.9\end{array}$ & $\begin{array}{l}260 \\
261 \\
262 \\
263 \\
264\end{array}$ & $\begin{array}{l}3802.72 \\
3825.16 \\
3847.63 \\
3870.13 \\
3892.66\end{array}$ & $\begin{array}{l}22.417 \\
22.450 \\
22.484 \\
22.519 \\
22.554\end{array}$ & $\begin{array}{l}33.6 \\
34.0 \\
34.3 \\
34.6 \\
34.7\end{array}$ & & & & \\
\hline $\begin{array}{l}205 \\
206 \\
207 \\
208 \\
209\end{array}$ & $\begin{array}{l}2621.40 \\
2641.82 \\
2662.29 \\
2682.80 \\
2703.36\end{array}$ & $\begin{array}{l}20.403 \\
20.447 \\
20.490 \\
20.534 \\
20.577\end{array}$ & $\begin{array}{l}43.7 \\
43.6 \\
43.4 \\
43.2 \\
43.1\end{array}$ & $\begin{array}{l}265 \\
266 \\
267 \\
268 \\
269\end{array}$ & $\begin{array}{l}3915.23 \\
3937.84 \\
3960.48 \\
3983.15 \\
4005.86\end{array}$ & $\begin{array}{l}22.588 \\
22.623 \\
22.657 \\
22.691 \\
22.724\end{array}$ & $\begin{array}{l}34.7 \\
34.5 \\
34.1 \\
33.3 \\
32.2\end{array}$ & & & & \\
\hline $\begin{array}{l}210 \\
211 \\
212 \\
213 \\
214\end{array}$ & $\begin{array}{l}2723.96 \\
2744 \cdot 60 \\
2765.28 \\
2786.01 \\
2806.78\end{array}$ & $\begin{array}{l}20.620 \\
20.663 \\
20.705 \\
20.748 \\
20.790\end{array}$ & $\begin{array}{l}42.9 \\
42.7 \\
42.6 \\
42.4 \\
42.2\end{array}$ & $\begin{array}{l}270 \\
271 \\
272 \\
273 \\
274\end{array}$ & $\begin{array}{l}4028.60 \\
4051.37 \\
4074.17 \\
4096.99 \\
4119.84\end{array}$ & $\begin{array}{l}22.755 \\
22.785 \\
22.812 \\
22.836 \\
22.856\end{array}$ & $\begin{array}{l}30.6 \\
28.4 \\
25.6 \\
22.1 \\
17.6\end{array}$ & & & & \\
\hline $\begin{array}{l}215 \\
216 \\
217 \\
218 \\
219\end{array}$ & $\begin{array}{l}2827 \cdot 59 \\
2848 \cdot 44 \\
2869 \cdot 34 \\
2890 \cdot 27 \\
2911.25\end{array}$ & $\begin{array}{l}20.832 \\
20.874 \\
20.916 \\
20.957 \\
20.998\end{array}$ & $\begin{array}{l}42.0 \\
41.8 \\
41.6 \\
41.3 \\
41.1\end{array}$ & $\begin{array}{l}275 \\
276 \\
277 \\
278 \\
279\end{array}$ & $\begin{array}{l}4142 \cdot 70 \\
4165 \cdot 58 \\
4188 \cdot 46 \\
4211.34 \\
4234.20\end{array}$ & $\begin{array}{l}22.871 \\
22.879 \\
22.881 \\
22.874 \\
22.856\end{array}$ & $\begin{array}{r}12.1 \\
5.4 \\
-2.7 \\
-12.3 \\
-23.7\end{array}$ & & & & \\
\hline $\begin{array}{l}220 \\
221 \\
222 \\
223 \\
224\end{array}$ & $\begin{array}{l}2932.27 \\
2953 \cdot 33 \\
2974.43 \\
2995 \cdot 57 \\
3016.75\end{array}$ & $\begin{array}{l}21.039 \\
21.080 \\
21.120 \\
21.160 \\
21.200\end{array}$ & $\begin{array}{l}40.8 \\
40.5 \\
40.2 \\
39.9 \\
39.6\end{array}$ & 280 & 4257.05 & 22.826 & -37.1 & & & & \\
\hline $\begin{array}{l}225 \\
226 \\
227 \\
228 \\
229\end{array}$ & $\begin{array}{l}3037.97 \\
3059.23 \\
3080.52 \\
3101.86 \\
3123.24\end{array}$ & $\begin{array}{l}21.240 \\
21.279 \\
21.317 \\
21.356 \\
21.394\end{array}$ & $\begin{array}{l}39.3 \\
38.9 \\
38.5 \\
38.1 \\
37.7\end{array}$ & & & & & & & & \\
\hline $\begin{array}{l}230 \\
231 \\
232 \\
233 \\
234\end{array}$ & $\begin{array}{l}3144.65 \\
3166.10 \\
3187.59 \\
3209.11 \\
3230.67\end{array}$ & $\begin{array}{l}21.431 \\
21.468 \\
21.505 \\
21.541 \\
21.577\end{array}$ & $\begin{array}{l}37 \cdot 3 \\
36 \cdot 9 \\
36 \cdot 5 \\
36 \cdot 0 \\
35.6\end{array}$ & & & & & & & & \\
\hline $\begin{array}{l}235 \\
236 \\
237 \\
238 \\
239\end{array}$ & $\begin{array}{l}3252 \cdot 26 \\
3273 \cdot 89 \\
3295.56 \\
3317 \cdot 26 \\
3338.99\end{array}$ & $\begin{array}{l}21.612 \\
21 \cdot 647 \\
21 \cdot 682 \\
21 \cdot 716 \\
21.749\end{array}$ & $\begin{array}{l}35.1 \\
34.7 \\
34.2 \\
33.8 \\
33.4\end{array}$ & & & & & & & & \\
\hline 240 & 3360.75 & 21.783 & 33.0 & & & & & & & & \\
\hline
\end{tabular}




\begin{tabular}{|c|c|c|c|c|c|c|c|c|c|c|c|}
\hline $\begin{array}{l}T \\
K\end{array}$ & $\underset{\mu v}{E}$ & $\stackrel{S}{\mu \vee / K}$ & $\begin{array}{l}d S / d T \\
n V / K^{2}\end{array}$ & $\begin{array}{l}T \\
K\end{array}$ & $\underset{\mu v}{E}$ & $\underset{\mu \vee / K}{S}$ & $\begin{array}{l}d S / d T \\
n V / K^{2}\end{array}$ & $\begin{array}{l}\mathrm{T} \\
\mathrm{K}\end{array}$ & $\begin{array}{l}E \\
\mu V\end{array}$ & $\underset{\mu V / K}{S}$ & $\begin{array}{l}d S / d T \\
n v / K^{2}\end{array}$ \\
\hline $\begin{array}{l}0 \\
1 \\
2 \\
3 \\
4\end{array}$ & $\begin{array}{l}0.00 \\
0.10 \\
0.59 \\
1.46 \\
2.68\end{array}$ & $\begin{array}{r}-0.113 \\
0.301 \\
0.687 \\
1.048 \\
1.387\end{array}$ & $\begin{array}{l}429.0 \\
399.5 \\
373.2 \\
349.6 \\
328.5\end{array}$ & $\begin{array}{l}60 \\
61 \\
62 \\
63 \\
64\end{array}$ & $\begin{array}{l}403.80 \\
415.77 \\
427.88 \\
440.15 \\
452.57\end{array}$ & $\begin{array}{l}11.890 \\
12.041 \\
12.191 \\
12.341 \\
12.490\end{array}$ & $\begin{array}{l}151.3 \\
150.6 \\
149.8 \\
149.1 \\
148.4\end{array}$ & $\begin{array}{l}120 \\
121 \\
122 \\
123 \\
124\end{array}$ & $\begin{array}{l}1369.97 \\
1390.10 \\
1410.36 \\
1430.74 \\
1451.25\end{array}$ & $\begin{array}{l}20.070 \\
20.195 \\
20.320 \\
20.444 \\
20.568\end{array}$ & $\begin{array}{l}125.1 \\
124.7 \\
124.4 \\
124.1 \\
123.7\end{array}$ \\
\hline $\begin{array}{l}5 \\
6 \\
7 \\
8 \\
9\end{array}$ & $\begin{array}{r}4.23 \\
6.09 \\
8.24 \\
10.67 \\
13.36\end{array}$ & $\begin{array}{l}1.706 \\
2.007 \\
2.292 \\
2.564 \\
2.822\end{array}$ & $\begin{array}{l}309.7 \\
292.9 \\
278.0 \\
264.9 \\
253.2\end{array}$ & $\begin{array}{l}65 \\
66 \\
67 \\
68 \\
69\end{array}$ & $\begin{array}{l}465.13 \\
477.84 \\
490.70 \\
503.70 \\
516.85\end{array}$ & $\begin{array}{l}12.638 \\
12.785 \\
12.932 \\
13.078 \\
13.223\end{array}$ & $\begin{array}{l}147.7 \\
147.0 \\
146.4 \\
145.7 \\
145.1\end{array}$ & $\begin{array}{l}125 \\
126 \\
127 \\
128 \\
129\end{array}$ & $\begin{array}{l}1471.87 \\
1492.63 \\
1513.50 \\
1534.50 \\
1555.62\end{array}$ & $\begin{array}{l}20.691 \\
20.815 \\
20.937 \\
21.060 \\
21.182\end{array}$ & $\begin{array}{l}123.4 \\
123.0 \\
122.7 \\
122.4 \\
122.0\end{array}$ \\
\hline $\begin{array}{l}10 \\
11 \\
12 \\
13 \\
14\end{array}$ & $\begin{array}{l}16.31 \\
19.50 \\
22.92 \\
26.57 \\
30.44\end{array}$ & $\begin{array}{l}3.070 \\
3.309 \\
3.539 \\
3.761 \\
3.977\end{array}$ & $\begin{array}{l}242.9 \\
233.9 \\
225.9 \\
218.9 \\
212.8\end{array}$ & $\begin{array}{l}70 \\
71 \\
72 \\
73 \\
74\end{array}$ & $\begin{array}{l}530.15 \\
543.59 \\
557.17 \\
570.90 \\
584.77\end{array}$ & $\begin{array}{l}13.368 \\
13.512 \\
13.656 \\
13.799 \\
13.941\end{array}$ & $\begin{array}{l}144.5 \\
143.9 \\
143.4 \\
142.8 \\
142.3\end{array}$ & $\begin{array}{l}130 \\
131 \\
132 \\
133 \\
134\end{array}$ & $\begin{array}{l}1576.87 \\
1598.23 \\
1619.72 \\
1641.33 \\
1663.05\end{array}$ & $\begin{array}{l}21.304 \\
21.426 \\
21.547 \\
21.668 \\
21.788\end{array}$ & $\begin{array}{l}121.7 \\
121.4 \\
121.1 \\
120.8 \\
120.5\end{array}$ \\
\hline $\begin{array}{l}15 \\
16 \\
17 \\
18 \\
19\end{array}$ & $\begin{array}{l}34.52 \\
38.81 \\
43.31 \\
48.00 \\
52.88\end{array}$ & $\begin{array}{l}4.187 \\
4.392 \\
4.593 \\
4.789 \\
4.983\end{array}$ & $\begin{array}{l}207.5 \\
202.8 \\
198.7 \\
195.2 \\
192.1\end{array}$ & $\begin{array}{l}75 \\
76 \\
77 \\
78 \\
79\end{array}$ & $\begin{array}{l}598.78 \\
612.94 \\
627.23 \\
641.67 \\
656.25\end{array}$ & $\begin{array}{l}14.083 \\
14.225 \\
14.366 \\
14.506 \\
14.647\end{array}$ & $\begin{array}{l}141.8 \\
141.3 \\
140.8 \\
140.3 \\
139.9\end{array}$ & $\begin{array}{l}135 \\
136 \\
137 \\
138 \\
139\end{array}$ & $\begin{array}{l}1684.90 \\
1706.87 \\
1728.96 \\
1751.17 \\
1773.50\end{array}$ & $\begin{array}{l}21.909 \\
22.029 \\
22.148 \\
22.268 \\
22.387\end{array}$ & $\begin{array}{l}120.2 \\
119.9 \\
119.6 \\
119.3 \\
119.0\end{array}$ \\
\hline $\begin{array}{l}20 \\
21 \\
22 \\
23 \\
24\end{array}$ & $\begin{array}{l}57.96 \\
63.23 \\
68.69 \\
74.33 \\
80.15\end{array}$ & $\begin{array}{l}5.174 \\
5.362 \\
5.548 \\
5.733 \\
5.915\end{array}$ & $\begin{array}{l}189.5 \\
187.2 \\
185.1 \\
183.3 \\
181.8\end{array}$ & $\begin{array}{l}80 \\
81 \\
82 \\
83 \\
84\end{array}$ & $\begin{array}{l}670.96 \\
685.82 \\
700.81 \\
715.95 \\
731.22\end{array}$ & $\begin{array}{l}14.786 \\
14.925 \\
15.064 \\
15.203 \\
15.341\end{array}$ & $\begin{array}{l}139.4 \\
139.0 \\
138.6 \\
138.2 \\
137.8\end{array}$ & $\begin{array}{l}140 \\
141 \\
142 \\
143 \\
144\end{array}$ & $\begin{array}{l}1795.94 \\
1818.51 \\
1841.19 \\
1863.99 \\
1886.91\end{array}$ & $\begin{array}{l}22.506 \\
22.524 \\
22.743 \\
22.861 \\
22.978\end{array}$ & $\begin{array}{l}118.7 \\
118.4 \\
118.1 \\
117.9 \\
117.6\end{array}$ \\
\hline $\begin{array}{l}25 \\
26 \\
27 \\
28 \\
29\end{array}$ & $\begin{array}{r}86.16 \\
92.34 \\
98.71 \\
105.25 \\
111.97\end{array}$ & $\begin{array}{l}6.096 \\
6.276 \\
6.455 \\
6.632 \\
6.809\end{array}$ & $\begin{array}{l}180.4 \\
179.2 \\
178.1 \\
177.1 \\
176.2\end{array}$ & $\begin{array}{l}85 \\
86 \\
87 \\
88 \\
89\end{array}$ & $\begin{array}{l}746.63 \\
762.17 \\
777.86 \\
793.68 \\
809.63\end{array}$ & $\begin{array}{l}15.478 \\
15.615 \\
15.752 \\
15.889 \\
16.025\end{array}$ & $\begin{array}{l}137.4 \\
137.0 \\
136.6 \\
136.3 \\
135.9\end{array}$ & $\begin{array}{l}145 \\
146 \\
147 \\
148 \\
149\end{array}$ & $\begin{array}{l}1909.95 \\
1933.10 \\
1956.38 \\
1979.76 \\
2003.27\end{array}$ & $\begin{array}{l}23.096 \\
23.213 \\
23.330 \\
23.447 \\
23.563\end{array}$ & $\begin{array}{l}117.3 \\
117.1 \\
116.8 \\
116.6 \\
116.3\end{array}$ \\
\hline $\begin{array}{l}30 \\
31 \\
32 \\
33 \\
34\end{array}$ & $\begin{array}{l}118.87 \\
125.94 \\
133.19 \\
140.61 \\
148.20\end{array}$ & $\begin{array}{l}6.984 \\
7.159 \\
7.333 \\
7.507 \\
7.679\end{array}$ & $\begin{array}{l}175.3 \\
174.5 \\
173.7 \\
172.9 \\
172.2\end{array}$ & $\begin{array}{l}90 \\
91 \\
92 \\
93 \\
94\end{array}$ & $\begin{array}{l}825.73 \\
841.95 \\
858.32 \\
874.82 \\
891.45\end{array}$ & $\begin{array}{l}16.160 \\
16.296 \\
16.431 \\
16.565 \\
16.700\end{array}$ & $\begin{array}{l}135.5 \\
135.2 \\
134.8 \\
134.5 \\
134.1\end{array}$ & $\begin{array}{l}150 \\
151 \\
152 \\
153 \\
154\end{array}$ & $\begin{array}{l}2026.89 \\
2050.63 \\
2074.48 \\
2098.45 \\
2122.53\end{array}$ & $\begin{array}{l}23.679 \\
23.795 \\
23.911 \\
24.026 \\
24.141\end{array}$ & $\begin{array}{l}116.0 \\
115.8 \\
115.5 \\
115.3 \\
115.0\end{array}$ \\
\hline $\begin{array}{l}35 \\
36 \\
37 \\
38 \\
39\end{array}$ & $\begin{array}{l}155.97 \\
163.90 \\
172.01 \\
180.29 \\
188.73\end{array}$ & $\begin{array}{l}7.851 \\
8.022 \\
8.193 \\
8.362 \\
8.531\end{array}$ & $\begin{array}{l}171.5 \\
170.7 \\
170.0 \\
169.3 \\
168.5\end{array}$ & $\begin{array}{l}95 \\
96 \\
97 \\
98 \\
99\end{array}$ & $\begin{array}{l}908.21 \\
925.12 \\
942.15 \\
959.32 \\
976.62\end{array}$ & $\begin{array}{l}16.834 \\
16.967 \\
17.100 \\
17.233 \\
17.366\end{array}$ & $\begin{array}{l}133.8 \\
133.4 \\
133.1 \\
132.8 \\
132.4\end{array}$ & $\begin{array}{l}155 \\
156 \\
157 \\
158 \\
159\end{array}$ & $\begin{array}{l}2146.73 \\
2171.05 \\
2195.47 \\
2220.02 \\
2244.67\end{array}$ & $\begin{array}{l}24.256 \\
24.371 \\
24.485 \\
24.600 \\
24.714\end{array}$ & $\begin{array}{l}114.8 \\
114.5 \\
114.3 \\
114.0 \\
113.8\end{array}$ \\
\hline $\begin{array}{l}40 \\
41 \\
42 \\
43 \\
44\end{array}$ & $\begin{array}{l}197.35 \\
206.13 \\
215.08 \\
224.20 \\
233.48\end{array}$ & $\begin{array}{l}8.699 \\
8.867 \\
9.033 \\
9.199 \\
9.364\end{array}$ & $\begin{array}{l}167.8 \\
167.0 \\
166.2 \\
165.4 \\
164.6\end{array}$ & $\begin{array}{l}100 \\
101 \\
102 \\
103 \\
104\end{array}$ & $\begin{array}{r}994.05 \\
1011.61 \\
1029.31 \\
1047.14 \\
1065.09\end{array}$ & $\begin{array}{l}17.498 \\
17.630 \\
17.762 \\
17.893 \\
18.024\end{array}$ & $\begin{array}{l}132.1 \\
131.7 \\
131.4 \\
131.1 \\
130.7\end{array}$ & $\begin{array}{l}160 \\
161 \\
162 \\
163 \\
164\end{array}$ & $\begin{array}{l}2269.44 \\
2294.33 \\
2319.32 \\
2344.44 \\
2369.66\end{array}$ & $\begin{array}{l}24.827 \\
24.941 \\
25.054 \\
25.167 \\
25.279\end{array}$ & $\begin{array}{l}113.5 \\
113.3 \\
113.0 \\
112.8 \\
112.5\end{array}$ \\
\hline $\begin{array}{l}45 \\
46 \\
47 \\
48 \\
49\end{array}$ & $\begin{array}{l}242.93 \\
252.54 \\
262.31 \\
272.25 \\
282.34\end{array}$ & $\begin{array}{r}9.528 \\
9.692 \\
9.854 \\
10.016 \\
10.177\end{array}$ & $\begin{array}{l}163.8 \\
162.9 \\
162.1 \\
161.3 \\
160.4\end{array}$ & $\begin{array}{l}105 \\
106 \\
107 \\
108 \\
109\end{array}$ & $\begin{array}{l}1083.18 \\
1101.40 \\
1119.75 \\
1138.23 \\
1156.84\end{array}$ & $\begin{array}{l}18.154 \\
18.285 \\
18.414 \\
18.544 \\
18.673\end{array}$ & $\begin{array}{l}130.4 \\
130.0 \\
129.7 \\
129.3 \\
129.0\end{array}$ & $\begin{array}{l}165 \\
166 \\
167 \\
168 \\
169\end{array}$ & $\begin{array}{l}2394.99 \\
2420.44 \\
2446.00 \\
2471.67 \\
2497.46\end{array}$ & $\begin{array}{l}25.392 \\
25.504 \\
25.616 \\
25.727 \\
25.839\end{array}$ & $\begin{array}{l}112.3 \\
112.0 \\
111.7 \\
1111.5 \\
111.2\end{array}$ \\
\hline $\begin{array}{l}50 \\
51 \\
52 \\
53 \\
54\end{array}$ & $\begin{array}{l}292.60 \\
303.01 \\
313.59 \\
324.32 \\
335.21\end{array}$ & $\begin{array}{l}10.337 \\
10.496 \\
10.654 \\
10.811 \\
10.968\end{array}$ & $\begin{array}{l}159.6 \\
158.7 \\
157.9 \\
157.0 \\
156.2\end{array}$ & $\begin{array}{l}110 \\
111 \\
112 \\
113 \\
114\end{array}$ & $\begin{array}{l}1175.58 \\
1194.44 \\
1213.44 \\
1232.56 \\
1251.81\end{array}$ & $\begin{array}{l}18.802 \\
18.930 \\
19.058 \\
19.186 \\
19.313\end{array}$ & $\begin{array}{l}128.6 \\
1.28 .3 \\
127.9 \\
127.6 \\
127.2\end{array}$ & $\begin{array}{l}170 \\
171 \\
172 \\
173 \\
174\end{array}$ & $\begin{array}{l}2523.35 \\
2549.36 \\
2575.47 \\
2601.70 \\
2628.03\end{array}$ & $\begin{array}{l}25.950 \\
26.061 \\
26.171 \\
26.281 \\
26.391\end{array}$ & $\begin{array}{l}110.9 \\
110.6 \\
110.4 \\
110.1 \\
109.8\end{array}$ \\
\hline $\begin{array}{l}55 \\
56 \\
57 \\
58 \\
59\end{array}$ & $\begin{array}{l}346.26 \\
357.46 \\
368.81 \\
380.32 \\
391.99\end{array}$ & $\begin{array}{l}11.124 \\
11.279 \\
11.433 \\
11.586 \\
11.739\end{array}$ & $\begin{array}{l}155.3 \\
154.5 \\
153.7 \\
152.9 \\
152.1\end{array}$ & $\begin{array}{l}115 \\
116 \\
117 \\
118 \\
119\end{array}$ & $\begin{array}{l}1271.19 \\
1290.69 \\
1310.32 \\
1330.08 \\
1349.96\end{array}$ & $\begin{array}{l}19.440 \\
19.567 \\
19.693 \\
19.819 \\
19.945\end{array}$ & $\begin{array}{l}126.8 \\
126.5 \\
126.1 \\
125.8 \\
125.4\end{array}$ & $\begin{array}{l}175 \\
176 \\
177 \\
178 \\
179\end{array}$ & $\begin{array}{l}2654.48 \\
2681.04 \\
2707.70 \\
2734.47 \\
2761.36\end{array}$ & $\begin{array}{l}26.501 \\
26.610 \\
26.719 \\
26.828 \\
26.936\end{array}$ & $\begin{array}{l}109.5 \\
109.2 \\
108.9 \\
108.6 \\
108.3\end{array}$ \\
\hline 60 & 403.80 & 11.890 & 151.3 & 120 & 1369.97 & 20.070 & 125.1 & 180 & 2788.35 & 27.045 & 108.0 \\
\hline
\end{tabular}




\begin{tabular}{|c|c|c|c|c|c|c|c|c|c|c|c|}
\hline $\begin{array}{l}T \\
K\end{array}$ & $\underset{\mu v}{E}$ & $\mu \stackrel{S}{\mu V / K}$ & $\begin{array}{l}d S / d T \\
n V / K^{2}\end{array}$ & $\begin{array}{l}T \\
K\end{array}$ & $\begin{array}{c}E v \\
\mu v\end{array}$ & $\mu^{S} \mathrm{~V} / \mathrm{K}$ & $\begin{array}{l}d s / d T \\
n V / K^{2}\end{array}$ & $\begin{array}{l}T \\
K\end{array}$ & $\begin{array}{l}E V \\
\mu V\end{array}$ & $\mu \stackrel{S}{V} / K$ & $\begin{array}{l}d s / d T \\
n V / k^{2}\end{array}$ \\
\hline $\begin{array}{l}180 \\
181 \\
182 \\
183 \\
184\end{array}$ & $\begin{array}{l}2788.35 \\
2815.45 \\
2842.65 \\
2869.97 \\
2897.39\end{array}$ & $\begin{array}{l}27.045 \\
27.152 \\
27.260 \\
27.367 \\
27.474\end{array}$ & $\begin{array}{l}108.0 \\
107.7 \\
107.3 \\
107.0 \\
106.7\end{array}$ & $\begin{array}{l}240 \\
241 \\
242 \\
243 \\
244\end{array}$ & $\begin{array}{l}4594.31 \\
4627.35 \\
4660.48 \\
4693.71 \\
4727.02\end{array}$ & $\begin{array}{l}32.995 \\
33.086 \\
33.178 \\
33.269 \\
33.361\end{array}$ & $\begin{array}{l}92.0 \\
91.8 \\
91.5 \\
91.3 \\
91.0\end{array}$ & & & & \\
\hline $\begin{array}{l}185 \\
186 \\
187 \\
188 \\
189\end{array}$ & $\begin{array}{l}2924.91 \\
2952.55 \\
2980.29 \\
3008.13 \\
3036.08\end{array}$ & $\begin{array}{l}27.581 \\
27.687 \\
27.793 \\
27.898 \\
28.003\end{array}$ & $\begin{array}{l}106.4 \\
106 \cdot 1 \\
105 \cdot 7 \\
105 \cdot 4 \\
105 \cdot 1\end{array}$ & $\begin{array}{l}245 \\
246 \\
247 \\
248 \\
249\end{array}$ & $\begin{array}{l}4760.43 \\
4793.92 \\
4827.51 \\
4861.19 \\
4894.96\end{array}$ & $\begin{array}{l}33.451 \\
33.542 \\
33.632 \\
33.722 \\
33.812\end{array}$ & $\begin{array}{l}90.7 \\
90.5 \\
90.2 \\
89.9 \\
89.6\end{array}$ & & & & \\
\hline $\begin{array}{l}190 \\
191 \\
192 \\
193 \\
194\end{array}$ & $\begin{array}{l}3064.14 \\
3092 \cdot 30 \\
3120.57 \\
3148.93 \\
3177.41\end{array}$ & $\begin{array}{l}28.108 \\
28.213 \\
28.317 \\
28.421 \\
28.525\end{array}$ & $\begin{array}{l}104.7 \\
104.4 \\
104 \cdot 1 \\
103 \cdot 8 \\
103.4\end{array}$ & $\begin{array}{l}250 \\
251 \\
252 \\
253 \\
254\end{array}$ & $\begin{array}{l}4928.81 \\
4962.76 \\
4996.80 \\
5030.92 \\
5065.13\end{array}$ & $\begin{array}{l}33.902 \\
33.991 \\
34.080 \\
34.168 \\
34.257\end{array}$ & $\begin{array}{l}89.3 \\
89.0 \\
88.7 \\
88.4 \\
88.1\end{array}$ & & & & \\
\hline $\begin{array}{l}195 \\
196 \\
197 \\
198 \\
199\end{array}$ & $\begin{array}{l}3205.98 \\
3234.66 \\
3263.45 \\
3292.33 \\
3321.32\end{array}$ & $\begin{array}{l}28.628 \\
28.731 \\
28.834 \\
28.936 \\
29.038\end{array}$ & $\begin{array}{l}103.1 \\
102.8 \\
102.4 \\
102.1 \\
101.8\end{array}$ & $\begin{array}{l}255 \\
256 \\
257 \\
258 \\
259\end{array}$ & $\begin{array}{l}5099.43 \\
5133.82 \\
5168.30 \\
5202.86 \\
5237.51\end{array}$ & $\begin{array}{l}34.344 \\
34.432 \\
34.519 \\
34.606 \\
34.693\end{array}$ & $\begin{array}{l}87.8 \\
87.4 \\
87.1 \\
86.7 \\
86.4\end{array}$ & & & & \\
\hline $\begin{array}{l}200 \\
201 \\
202 \\
203 \\
204\end{array}$ & $\begin{array}{l}3350.41 \\
3379.60 \\
3408.89 \\
3438.28 \\
3467.77\end{array}$ & $\begin{array}{l}29.139 \\
29.241 \\
29.342 \\
29.442 \\
29.543\end{array}$ & $\begin{array}{l}101 \cdot 5 \\
101 \cdot 2 \\
100 \cdot 9 \\
100.6 \\
100 \cdot 3\end{array}$ & $\begin{array}{l}260 \\
261 \\
262 \\
263 \\
264\end{array}$ & $\begin{array}{l}5272.24 \\
5307.07 \\
5341.97 \\
5376.97 \\
5412.05\end{array}$ & $\begin{array}{l}34.779 \\
34.865 \\
34.950 \\
35.036 \\
35.120\end{array}$ & $\begin{array}{l}86.0 \\
85.7 \\
85.3 \\
85.0 \\
84.6\end{array}$ & & & & \\
\hline $\begin{array}{l}205 \\
206 \\
207 \\
208 \\
209\end{array}$ & $\begin{array}{l}3497.36 \\
3527.06 \\
3556 \cdot 85 \\
3586.74 \\
3616.73\end{array}$ & $\begin{array}{l}29.643 \\
29.743 \\
29.842 \\
29.942 \\
30.041\end{array}$ & $\begin{array}{r}100.0 \\
99.7 \\
99.4 \\
99.1 \\
98.8\end{array}$ & $\begin{array}{l}265 \\
266 \\
267 \\
268 \\
269\end{array}$ & $\begin{array}{l}5447.21 \\
5482.45 \\
5517.79 \\
5553.20 \\
5588.70\end{array}$ & $\begin{array}{l}35.205 \\
35.289 \\
35.372 \\
35.455 \\
35.538\end{array}$ & $\begin{array}{l}84.2 \\
83.8 \\
83.4 \\
82.9 \\
82.5\end{array}$ & & & & \\
\hline $\begin{array}{l}210 \\
211 \\
212 \\
213 \\
214\end{array}$ & $\begin{array}{l}3646.82 \\
3677.01 \\
3707.30 \\
3737.68 \\
3768.17\end{array}$ & $\begin{array}{l}30.139 \\
30.238 \\
30.336 \\
30.434 \\
30.532\end{array}$ & $\begin{array}{l}98.6 \\
98.3 \\
98.0 \\
97.8 \\
97.5\end{array}$ & $\begin{array}{l}270 \\
271 \\
272 \\
273 \\
274\end{array}$ & $\begin{array}{l}5624.28 \\
5659.94 \\
5695.68 \\
5731.50 \\
5767.41\end{array}$ & $\begin{array}{l}35.620 \\
35.702 \\
35.783 \\
35.864 \\
35.944\end{array}$ & $\begin{array}{l}82.0 \\
81.5 \\
80.9 \\
80.3 \\
79.7\end{array}$ & & & & \\
\hline $\begin{array}{l}215 \\
216 \\
217 \\
218 \\
219\end{array}$ & $\begin{array}{l}3798.75 \\
3829.42 \\
3860.20 \\
3891.07 \\
3922.04\end{array}$ & $\begin{array}{l}30.629 \\
30.726 \\
30.823 \\
30.920 \\
31.016\end{array}$ & $\begin{array}{l}97.3 \\
97.1 \\
96.8 \\
96.6 \\
96.4\end{array}$ & $\begin{array}{l}275 \\
276 \\
277 \\
278 \\
279\end{array}$ & $\begin{array}{l}5803.39 \\
5839.45 \\
5875.59 \\
5911.81 \\
5948.11\end{array}$ & $\begin{array}{l}36.023 \\
36.102 \\
36.180 \\
36.257 \\
36.332\end{array}$ & $\begin{array}{l}79.0 \\
78.2 \\
77.3 \\
76.4 \\
75.3\end{array}$ & & & & \\
\hline $\begin{array}{l}220 \\
221 \\
222 \\
223 \\
224\end{array}$ & $\begin{array}{l}3953 \cdot 10 \\
3984 \cdot 26 \\
4015 \cdot 52 \\
4046 \cdot 87 \\
4078 \cdot 32\end{array}$ & $\begin{array}{l}31.113 \\
31.209 \\
31.304 \\
31.400 \\
31.495\end{array}$ & $\begin{array}{l}96.2 \\
95.9 \\
95.7 \\
95.5 \\
95.3\end{array}$ & 280 & 5984.48 & 36.407 & 74.0 & & & & \\
\hline $\begin{array}{l}225 \\
226 \\
227 \\
228 \\
229\end{array}$ & $\begin{array}{l}4109 \cdot 86 \\
4141.50 \\
4173.23 \\
4205 \cdot 06 \\
4236.98\end{array}$ & $\begin{array}{l}31.591 \\
31.686 \\
31.781 \\
31.875 \\
31.970\end{array}$ & $\begin{array}{l}95.1 \\
94.9 \\
94.7 \\
94.5 \\
94.3\end{array}$ & & & & & & & & \\
\hline $\begin{array}{l}230 \\
231 \\
232 \\
233 \\
234\end{array}$ & $\begin{array}{l}4269.00 \\
4301.11 \\
4333.32 \\
4365.62 \\
4398.01\end{array}$ & $\begin{array}{l}32.064 \\
32.158 \\
32.252 \\
32.345 \\
32.439\end{array}$ & $\begin{array}{l}94.1 \\
93.9 \\
93.7 \\
93.5 \\
93.3\end{array}$ & & & & & & & & \\
\hline $\begin{array}{l}235 \\
236 \\
237 \\
238 \\
239\end{array}$ & $\begin{array}{l}4430.49 \\
4463.07 \\
4495.74 \\
4528.51 \\
4561.36\end{array}$ & $\begin{array}{l}32.532 \\
32.625 \\
32.718 \\
32.810 \\
32.902\end{array}$ & $\begin{array}{l}93.1 \\
92.9 \\
92.7 \\
92.4 \\
92.2\end{array}$ & & & & & & & & \\
\hline 240 & 4594.31 & 32.995 & 92.0 & & & & & & & & \\
\hline
\end{tabular}




\begin{tabular}{|c|c|c|c|c|c|c|c|c|c|c|c|}
\hline $\begin{array}{l}T \\
K\end{array}$ & $\underset{\mu V}{E}$ & $\underset{\mu V / K}{S}$ & $\begin{array}{l}\mathrm{dS} / \mathrm{dT} \\
\mathrm{nV} / \mathrm{K}^{2}\end{array}$ & $\begin{array}{l}T \\
K\end{array}$ & $\begin{array}{c}E V \\
\mu V\end{array}$ & ${ }_{\mu v / K}^{S}$ & $\begin{array}{l}d s / d T \\
n V / K^{2}\end{array}$ & $\begin{array}{l}T \\
K\end{array}$ & $\underset{\mu v}{E}$ & $\stackrel{s}{s v / K}$ & $\begin{array}{l}d s / d T \\
n V / K^{2}\end{array}$ \\
\hline $\begin{array}{l}0 \\
1 \\
2 \\
3 \\
4\end{array}$ & $\begin{array}{r}-0.22 \\
0.18 \\
0.54 \\
0.87 \\
1.19\end{array}$ & $\begin{array}{l}0.430 \\
0.378 \\
0.342 \\
0.321 \\
0.311\end{array}$ & $\begin{array}{l}-60.6 \\
-43.2 \\
-28.3 \\
-15.4 \\
-4.5\end{array}$ & $\begin{array}{l}60 \\
61 \\
62 \\
63 \\
64\end{array}$ & $\begin{array}{l}82.49 \\
85.53 \\
88.65 \\
91.84 \\
95.10\end{array}$ & $\begin{array}{l}3.014 \\
3.083 \\
3.153 \\
3.223 \\
3.294\end{array}$ & $\begin{array}{l}69.0 \\
69.5 \\
70.0 \\
70.5 \\
70.9\end{array}$ & $\begin{array}{l}120 \\
121 \\
122 \\
123 \\
124\end{array}$ & $\begin{array}{l}397.96 \\
405.60 \\
413.33 \\
421.14 \\
429.02\end{array}$ & $\begin{array}{l}7.606 \\
7.686 \\
7.766 \\
7.846 \\
7.926\end{array}$ & $\begin{array}{l}80.0 \\
80.0 \\
79.9 \\
79.9 \\
79.8\end{array}$ \\
\hline $\begin{array}{l}5 \\
6 \\
7 \\
8 \\
9\end{array}$ & $\begin{array}{l}1.50 \\
1.81 \\
2.14 \\
2.48 \\
2.86\end{array}$ & $\begin{array}{l}0.311 \\
0.320 \\
0.336 \\
0.358 \\
0.384\end{array}$ & $\begin{array}{r}4.7 \\
12.5 \\
19.0 \\
24.5 \\
28.9\end{array}$ & $\begin{array}{l}65 \\
66 \\
67 \\
68 \\
69\end{array}$ & $\begin{array}{r}98.43 \\
101.83 \\
105.30 \\
108.85 \\
112.46\end{array}$ & $\begin{array}{l}3.365 \\
3.437 \\
3.509 \\
3.581 \\
3.653\end{array}$ & $\begin{array}{l}71.3 \\
71.7 \\
72.1 \\
72.5 \\
72.8\end{array}$ & $\begin{array}{l}125 \\
126 \\
127 \\
128 \\
129\end{array}$ & $\begin{array}{l}436.99 \\
445.03 \\
453.16 \\
461.36 \\
469.64\end{array}$ & $\begin{array}{l}8.005 \\
8.085 \\
8.164 \\
8.244 \\
8.323\end{array}$ & $\begin{array}{l}79.7 \\
79.6 \\
79.4 \\
79.3 \\
79.2\end{array}$ \\
\hline $\begin{array}{l}10 \\
11 \\
12 \\
13 \\
14\end{array}$ & $\begin{array}{l}3.25 \\
3.69 \\
4.15 \\
4.66 \\
5.20\end{array}$ & $\begin{array}{l}0.415 \\
0.449 \\
0.486 \\
0.525 \\
0.565\end{array}$ & $\begin{array}{l}32.6 \\
35.5 \\
37.8 \\
39.7 \\
41.1\end{array}$ & $\begin{array}{l}70 \\
71 \\
72 \\
73 \\
74\end{array}$ & $\begin{array}{l}116.15 \\
119.92 \\
123.75 \\
127.66 \\
131.65\end{array}$ & $\begin{array}{l}3.726 \\
3.800 \\
3.873 \\
3.947 \\
4.021\end{array}$ & $\begin{array}{l}73.1 \\
73.4 \\
73.7 \\
73.9 \\
74.2\end{array}$ & $\begin{array}{l}130 \\
131 \\
132 \\
133 \\
134\end{array}$ & $\begin{array}{l}478.01 \\
486.45 \\
494.97 \\
503.57 \\
512.25\end{array}$ & $\begin{array}{l}8.402 \\
8.481 \\
8.560 \\
8.638 \\
8.717\end{array}$ & $\begin{array}{l}79.0 \\
78.8 \\
78.6 \\
78.5 \\
78.3\end{array}$ \\
\hline $\begin{array}{l}15 \\
16 \\
17 \\
18 \\
19\end{array}$ & $\begin{array}{l}5.79 \\
6.42 \\
7.09 \\
7.80 \\
8.56\end{array}$ & $\begin{array}{l}0.607 \\
0.649 \\
0.693 \\
0.736 \\
0.781\end{array}$ & $\begin{array}{l}42 \cdot 2 \\
43 \cdot 0 \\
43 \cdot 6 \\
44 \cdot 0 \\
44.3\end{array}$ & $\begin{array}{l}75 \\
76 \\
77 \\
78 \\
79\end{array}$ & $\begin{array}{l}135.71 \\
139.84 \\
144.05 \\
148.33 \\
152.68\end{array}$ & $\begin{array}{l}4.095 \\
4.170 \\
4.245 \\
4.319 \\
4.395\end{array}$ & $\begin{array}{l}74 \cdot 4 \\
74.6 \\
74.8 \\
75.0 \\
75.2\end{array}$ & $\begin{array}{l}135 \\
136 \\
137 \\
138 \\
139\end{array}$ & $\begin{array}{l}521.00 \\
529.83 \\
538.75 \\
547.74 \\
556.80\end{array}$ & $\begin{array}{l}8.795 \\
8.873 \\
8.950 \\
9.028 \\
9.105\end{array}$ & $\begin{array}{l}78.1 \\
77.8 \\
77.6 \\
77.4 \\
77.2\end{array}$ \\
\hline $\begin{array}{l}20 \\
21 \\
22 \\
23 \\
24\end{array}$ & $\begin{array}{r}9.36 \\
10.21 \\
11.10 \\
12.04 \\
13.02\end{array}$ & $\begin{array}{l}0.825 \\
0.870 \\
0.914 \\
0.959 \\
1.004\end{array}$ & $\begin{array}{l}44 \cdot 6 \\
44 \cdot 7 \\
44 \cdot 9 \\
45 \cdot 0 \\
45 \cdot 1\end{array}$ & $\begin{array}{l}80 \\
81 \\
82 \\
83 \\
84\end{array}$ & $\begin{array}{l}157.12 \\
161.62 \\
166.21 \\
170.87 \\
175.60\end{array}$ & $\begin{array}{l}4.470 \\
4.545 \\
4.621 \\
4.697 \\
4.773\end{array}$ & $\begin{array}{l}75.4 \\
75.6 \\
75.8 \\
76.0 \\
76.1\end{array}$ & $\begin{array}{l}140 \\
141 \\
142 \\
143 \\
144\end{array}$ & $\begin{array}{l}565.95 \\
575.17 \\
584.46 \\
593.84 \\
603.29\end{array}$ & $\begin{array}{l}9.182 \\
9.259 \\
9.336 \\
9.412 \\
9.488\end{array}$ & $\begin{array}{l}76.9 \\
76.7 \\
76.5 \\
76.2 \\
76.0\end{array}$ \\
\hline $\begin{array}{l}25 \\
26 \\
27 \\
28 \\
29\end{array}$ & $\begin{array}{l}14.05 \\
15.12 \\
16.24 \\
17.40 \\
18.61\end{array}$ & $\begin{array}{l}1.050 \\
1.095 \\
1.141 \\
1.187 \\
1.233\end{array}$ & $\begin{array}{l}45.3 \\
45.5 \\
45.7 \\
46.0 \\
46.4\end{array}$ & $\begin{array}{l}85 \\
86 \\
87 \\
88 \\
89\end{array}$ & $\begin{array}{l}180.41 \\
185.30 \\
190.26 \\
195.30 \\
200.42\end{array}$ & $\begin{array}{l}4.849 \\
4.926 \\
5.002 \\
5.079 \\
5.156\end{array}$ & $\begin{array}{l}76.3 \\
76.5 \\
76.6 \\
76.8 \\
77.0\end{array}$ & $\begin{array}{l}145 \\
146 \\
147 \\
148 \\
149\end{array}$ & $\begin{array}{l}612.81 \\
622.42 \\
632.09 \\
641.85 \\
651.67\end{array}$ & $\begin{array}{l}9.564 \\
9.640 \\
9.715 \\
9.790 \\
9.865\end{array}$ & $\begin{array}{l}75.7 \\
75.5 \\
75.2 \\
75.0 \\
74.7\end{array}$ \\
\hline $\begin{array}{l}30 \\
31 \\
32 \\
33 \\
34\end{array}$ & $\begin{array}{l}19.87 \\
21.17 \\
22.52 \\
23.92 \\
25.37\end{array}$ & $\begin{array}{l}1.279 \\
1.326 \\
1.374 \\
1.422 \\
1.471\end{array}$ & $\begin{array}{l}46 \cdot 8 \\
47 \cdot 3 \\
47 \cdot 8 \\
48 \cdot 3 \\
49.0\end{array}$ & $\begin{array}{l}90 \\
91 \\
92 \\
93 \\
94\end{array}$ & $\begin{array}{l}205.62 \\
210.89 \\
216.24 \\
221.66 \\
227.17\end{array}$ & $\begin{array}{l}5.233 \\
5.310 \\
5.387 \\
5.465 \\
5.543\end{array}$ & $\begin{array}{l}77.1 \\
77.3 \\
77.5 \\
77.6 \\
77.8\end{array}$ & $\begin{array}{l}150 \\
151 \\
152 \\
153 \\
154\end{array}$ & $\begin{array}{l}661.58 \\
671.55 \\
681.60 \\
691.73 \\
701.93\end{array}$ & $\begin{array}{r}9.939 \\
10.014 \\
10.088 \\
10.162 \\
10.235\end{array}$ & $\begin{array}{l}74.5 \\
74.2 \\
74.0 \\
73.8 \\
73.5\end{array}$ \\
\hline $\begin{array}{l}35 \\
36 \\
37 \\
38 \\
39\end{array}$ & $\begin{array}{l}26.86 \\
28.41 \\
30.00 \\
31.65 \\
33.35\end{array}$ & $\begin{array}{l}1.520 \\
1.570 \\
1.621 \\
1.672 \\
1.724\end{array}$ & $\begin{array}{l}49 \cdot 6 \\
50 \cdot 3 \\
51.1 \\
51.9 \\
52.7\end{array}$ & $\begin{array}{l}95 \\
96 \\
97 \\
98 \\
99\end{array}$ & $\begin{array}{l}232.75 \\
238.41 \\
244.14 \\
249.96 \\
255.85\end{array}$ & $\begin{array}{l}5.620 \\
5.698 \\
5.777 \\
5.855 \\
5.933\end{array}$ & $\begin{array}{l}77.9 \\
78.1 \\
78.2 \\
78.4 \\
78.5\end{array}$ & $\begin{array}{l}155 \\
156 \\
157 \\
158 \\
159\end{array}$ & $\begin{array}{l}712.20 \\
722.54 \\
732.96 \\
743.45 \\
754.02\end{array}$ & $\begin{array}{l}10.309 \\
10.382 \\
10.455 \\
10.528 \\
10.600\end{array}$ & $\begin{array}{l}73.3 \\
73.1 \\
72.8 \\
72.6 \\
72.4\end{array}$ \\
\hline $\begin{array}{l}40 \\
41 \\
42 \\
43 \\
44\end{array}$ & $\begin{array}{l}35.10 \\
36.90 \\
38.76 \\
40.67 \\
42.64\end{array}$ & $\begin{array}{l}1.778 \\
1.831 \\
1.886 \\
1.942 \\
1.999\end{array}$ & $\begin{array}{l}53.5 \\
54.4 \\
55.2 \\
56.1 \\
57.0\end{array}$ & $\begin{array}{l}100 \\
101 \\
102 \\
103 \\
104\end{array}$ & $\begin{array}{l}261.83 \\
267.88 \\
274.01 \\
280.22 \\
286.51\end{array}$ & $\begin{array}{l}6.012 \\
6.091 \\
6.170 \\
6.249 \\
6.328\end{array}$ & $\begin{array}{l}78.7 \\
78.8 \\
79.0 \\
79.1 \\
79.2\end{array}$ & $\begin{array}{l}160 \\
161 \\
162 \\
163 \\
164\end{array}$ & $\begin{array}{l}764.65 \\
775.36 \\
786.14 \\
797.00 \\
807.92\end{array}$ & $\begin{array}{l}10.673 \\
10.745 \\
10.816 \\
10.888 \\
10.960\end{array}$ & $\begin{array}{l}72.2 \\
72.0 \\
71.8 \\
71.5 \\
71.3\end{array}$ \\
\hline $\begin{array}{l}45 \\
46 \\
47 \\
48 \\
49\end{array}$ & $\begin{array}{l}44.67 \\
46.76 \\
48.90 \\
51.10 \\
53.37\end{array}$ & $\begin{array}{l}2.056 \\
2.114 \\
2.173 \\
2.234 \\
2.294\end{array}$ & $\begin{array}{l}57.9 \\
58.8 \\
59.6 \\
60.5 \\
61.3\end{array}$ & $\begin{array}{l}105 \\
106 \\
107 \\
108 \\
109\end{array}$ & $\begin{array}{l}292.87 \\
299.32 \\
305.85 \\
312.45 \\
319.14\end{array}$ & $\begin{array}{l}6.407 \\
6.487 \\
6.566 \\
6.646 \\
6.726\end{array}$ & $\begin{array}{l}79.4 \\
79.5 \\
79.6 \\
79.7 \\
79.8\end{array}$ & $\begin{array}{l}165 \\
166 \\
167 \\
168 \\
169\end{array}$ & $\begin{array}{l}818.92 \\
829.98 \\
841.12 \\
852.33 \\
863.61\end{array}$ & $\begin{array}{l}11.031 \\
11.102 \\
11.173 \\
11.243 \\
11.314\end{array}$ & $\begin{array}{l}71.1 \\
70.9 \\
70.7 \\
70.5 \\
70.3\end{array}$ \\
\hline $\begin{array}{l}50 \\
51 \\
52 \\
53 \\
54\end{array}$ & $\begin{array}{l}55.69 \\
58.08 \\
60.53 \\
63.04 \\
65.62\end{array}$ & $\begin{array}{l}2.356 \\
2.419 \\
2.482 \\
2.546 \\
2.611\end{array}$ & $\begin{array}{l}62.1 \\
62.9 \\
63.7 \\
64.5 \\
65.2\end{array}$ & $\begin{array}{l}110 \\
111 \\
112 \\
113 \\
114\end{array}$ & $\begin{array}{l}325.90 \\
332.75 \\
339.67 \\
346.68 \\
353.77\end{array}$ & $\begin{array}{l}6.805 \\
6.885 \\
6.965 \\
7.045 \\
7.125\end{array}$ & $\begin{array}{l}79.9 \\
79.9 \\
80.0 \\
80.0 \\
80.1\end{array}$ & $\begin{array}{l}170 \\
171 \\
172 \\
173 \\
174\end{array}$ & $\begin{array}{l}874.95 \\
886.37 \\
897.86 \\
909.42 \\
921.05\end{array}$ & $\begin{array}{l}11.384 \\
11.454 \\
11.524 \\
11.594 \\
11.663\end{array}$ & $\begin{array}{l}70.1 \\
69.9 \\
69.7 \\
69.5 \\
69.3\end{array}$ \\
\hline $\begin{array}{l}55 \\
56 \\
57 \\
58 \\
59\end{array}$ & $\begin{array}{l}68.27 \\
70.98 \\
73.75 \\
76.60 \\
79.51\end{array}$ & $\begin{array}{l}2.677 \\
2.743 \\
2.810 \\
2.877 \\
2.945\end{array}$ & $\begin{array}{l}65.9 \\
66.6 \\
67.2 \\
67.8 \\
68.4\end{array}$ & $\begin{array}{l}115 \\
116 \\
117 \\
118 \\
119\end{array}$ & $\begin{array}{l}360.93 \\
368.18 \\
375.50 \\
382.91 \\
390.39\end{array}$ & $\begin{array}{l}7.205 \\
7.285 \\
7.366 \\
7.446 \\
7.526\end{array}$ & $\begin{array}{l}80.1 \\
80.1 \\
80.1 \\
80.1 \\
80.1\end{array}$ & $\begin{array}{l}175 \\
176 \\
177 \\
178 \\
179\end{array}$ & $\begin{array}{l}932.75 \\
944.51 \\
956.35 \\
968.25 \\
980.23\end{array}$ & $\begin{array}{l}11.732 \\
11.801 \\
11.870 \\
11.938 \\
12.007\end{array}$ & $\begin{array}{l}69.1 \\
68.9 \\
68.7 \\
68.4 \\
68.2\end{array}$ \\
\hline 60 & 82.49 & 3.014 & 69.0 & 120 & 397.96 & 7.606 & 80.0 & 180 & 992.27 & 12.075 & 67.9 \\
\hline
\end{tabular}


TABLE 27. Type Ag-28 at\% Au versus $K N-$ thermoelectric voltage, E(T), Seebeck coefficient, $\mathrm{S}(\mathrm{T})$, and derivative of the Seebeck coefficient, dS(T) -Continued

\begin{tabular}{|c|c|c|c|c|c|c|c|c|c|c|c|}
\hline $\begin{array}{l}T \\
K\end{array}$ & $\underset{\mu v}{E}$ & $\stackrel{S}{\mu v / K}$ & $\begin{array}{l}d S / d T \\
n V / K^{2}\end{array}$ & $\begin{array}{l}T \\
k\end{array}$ & $\underset{\mu v}{E}$ & $\underset{\mu v / K}{S}$ & $\begin{array}{l}d S / d T \\
n V / K^{2}\end{array}$ & $\begin{array}{l}T \\
k\end{array}$ & $\begin{array}{l}E \\
\mu V\end{array}$ & $\underset{\mu v / K}{s}$ & $\begin{array}{l}d S / d T \\
n v / K^{2}\end{array}$ \\
\hline $\begin{array}{l}180 \\
181 \\
182 \\
183 \\
184\end{array}$ & $\begin{array}{r}992.27 \\
1004.38 \\
1016.55 \\
1028.80 \\
1041.11\end{array}$ & $\begin{array}{l}12.075 \\
12.143 \\
12.210 \\
12.277 \\
12.344\end{array}$ & $\begin{array}{l}67.9 \\
67.7 \\
67.4 \\
67.1 \\
66.8\end{array}$ & $\begin{array}{l}240 \\
241 \\
242 \\
243 \\
244\end{array}$ & $\begin{array}{l}1825.04 \\
1840.51 \\
1856.02 \\
1871.58 \\
1887.19\end{array}$ & $\begin{array}{l}15.443 \\
15.490 \\
15.536 \\
15.582 \\
15.627\end{array}$ & $\begin{array}{l}46.5 \\
46.2 \\
46.0 \\
45.7 \\
45.4\end{array}$ & & & & \\
\hline $\begin{array}{l}185 \\
186 \\
187 \\
188 \\
189\end{array}$ & $\begin{array}{l}1053.48 \\
1065.93 \\
1078.44 \\
1091.02 \\
1103.66\end{array}$ & $\begin{array}{l}12.411 \\
12.477 \\
12.544 \\
12.609 \\
12.675\end{array}$ & $\begin{array}{l}66.5 \\
66.2 \\
65.9 \\
65.6 \\
65.2\end{array}$ & $\begin{array}{l}245 \\
246 \\
247 \\
248 \\
249\end{array}$ & $\begin{array}{l}1902.84 \\
1918.53 \\
1934.27 \\
1950.05 \\
1965.88\end{array}$ & $\begin{array}{l}15.672 \\
15.717 \\
15.761 \\
15.805 \\
15.848\end{array}$ & $\begin{array}{l}45.0 \\
44.5 \\
44.1 \\
43.5 \\
42.9\end{array}$ & & & & \\
\hline $\begin{array}{l}190 \\
191 \\
192 \\
193 \\
194\end{array}$ & $\begin{array}{l}1116.37 \\
1129.14 \\
1141.97 \\
1154.87 \\
1167.84\end{array}$ & $\begin{array}{l}12.740 \\
12.804 \\
12.869 \\
12.932 \\
12.996\end{array}$ & $\begin{array}{l}64.8 \\
64.5 \\
64.1 \\
63.7 \\
63.2\end{array}$ & $\begin{array}{l}250 \\
251 \\
252 \\
253 \\
254\end{array}$ & $\begin{array}{l}1981.75 \\
1997.66 \\
2013.62 \\
2029.61 \\
2045.64\end{array}$ & $\begin{array}{l}15.891 \\
15.933 \\
15.974 \\
16.014 \\
16.053\end{array}$ & $\begin{array}{l}42.2 \\
41.4 \\
40.6 \\
39.7 \\
38.7\end{array}$ & & & & \\
\hline $\begin{array}{l}195 \\
196 \\
197 \\
198 \\
199\end{array}$ & $\begin{array}{l}1180.87 \\
1193.96 \\
1207.11 \\
1220.32 \\
1233.60\end{array}$ & $\begin{array}{l}13.059 \\
13.122 \\
13.184 \\
13.245 \\
13.307\end{array}$ & $\begin{array}{l}62.8 \\
62.4 \\
61.9 \\
61.5 \\
61.0\end{array}$ & $\begin{array}{l}255 \\
256 \\
257 \\
258 \\
259\end{array}$ & $\begin{array}{l}2061.71 \\
2077.82 \\
2093.97 \\
2110.15 \\
2126.37\end{array}$ & $\begin{array}{l}16.091 \\
16.128 \\
16.164 \\
16.199 \\
16.233\end{array}$ & $\begin{array}{l}37.7 \\
36.6 \\
35.4 \\
34.2 \\
33.0\end{array}$ & & & & \\
\hline $\begin{array}{l}200 \\
201 \\
202 \\
203 \\
204\end{array}$ & $\begin{array}{l}1246.94 \\
1260.33 \\
1273.79 \\
1287.31 \\
1300.89\end{array}$ & $\begin{array}{l}13.367 \\
13.428 \\
13.487 \\
13.547 \\
13.605\end{array}$ & $\begin{array}{l}60.5 \\
60.0 \\
59.5 \\
59.0 \\
58.5\end{array}$ & $\begin{array}{l}260 \\
261 \\
262 \\
263 \\
264\end{array}$ & $\begin{array}{l}2142.62 \\
2158.90 \\
2175.21 \\
2191.55 \\
2207.92\end{array}$ & $\begin{array}{l}16.265 \\
16.296 \\
16.326 \\
16.355 \\
16.383\end{array}$ & $\begin{array}{l}31.8 \\
30.6 \\
29.4 \\
28.3 \\
27.3\end{array}$ & & & & \\
\hline $\begin{array}{l}205 \\
206 \\
207 \\
208 \\
209\end{array}$ & $\begin{array}{l}1314.52 \\
1328.21 \\
1341.96 \\
1355.77 \\
1369.63\end{array}$ & $\begin{array}{l}13.664 \\
13.721 \\
13.778 \\
13.835 \\
13.891\end{array}$ & $\begin{array}{l}58.0 \\
57.4 \\
56.9 \\
56.4 \\
55.9\end{array}$ & $\begin{array}{l}265 \\
266 \\
267 \\
268 \\
269\end{array}$ & $\begin{array}{l}2224.32 \\
2240.74 \\
2257.19 \\
2273.66 \\
2290.16\end{array}$ & $\begin{array}{l}16.410 \\
16.436 \\
16.462 \\
16.487 \\
16.512\end{array}$ & $\begin{array}{l}26.4 \\
25.8 \\
25.4 \\
25.4 \\
25.8\end{array}$ & & & & \\
\hline $\begin{array}{l}210 \\
2111 \\
212 \\
213 \\
214\end{array}$ & $\begin{array}{l}1383.55 \\
1397.53 \\
1411.55 \\
1425.64 \\
1439.78\end{array}$ & $\begin{array}{l}13.947 \\
14.002 \\
14.057 \\
14.111 \\
14.164\end{array}$ & $\begin{array}{l}55.4 \\
54.9 \\
54.4 \\
53.9 \\
53.4\end{array}$ & $\begin{array}{l}270 \\
271 \\
272 \\
273 \\
274\end{array}$ & $\begin{array}{l}2306.69 \\
2323.24 \\
2339.82 \\
2356.43 \\
2373.08\end{array}$ & $\begin{array}{l}16.539 \\
16.566 \\
16.595 \\
16.627 \\
16.663\end{array}$ & $\begin{array}{l}26.7 \\
28.2 \\
30.4 \\
33.5 \\
37.5\end{array}$ & & & & \\
\hline $\begin{array}{l}215 \\
216 \\
217 \\
218 \\
219\end{array}$ & $\begin{array}{l}1453.97 \\
1468.21 \\
1482.51 \\
1496.86 \\
1511.26\end{array}$ & $\begin{array}{l}14.218 \\
14.270 \\
14.323 \\
14.374 \\
14.426\end{array}$ & $\begin{array}{l}52.9 \\
52.5 \\
52.1 \\
51.6 \\
51.2\end{array}$ & $\begin{array}{l}275 \\
276 \\
277 \\
278 \\
279\end{array}$ & $\begin{array}{l}2389.76 \\
2406.48 \\
2423.26 \\
2440.09 \\
2456.99\end{array}$ & $\begin{array}{l}16.703 \\
16.748 \\
16.801 \\
16.863 \\
16.936\end{array}$ & $\begin{array}{l}42.7 \\
49.2 \\
57.2 \\
66.9 \\
78.6\end{array}$ & & & & \\
\hline $\begin{array}{l}220 \\
221 \\
222 \\
223 \\
224\end{array}$ & $\begin{array}{l}1525.71 \\
1540.21 \\
1554.76 \\
1569.37 \\
1584.02\end{array}$ & $\begin{array}{l}14.477 \\
14.528 \\
14.578 \\
14.628 \\
14.678\end{array}$ & $\begin{array}{l}50.8 \\
50.5 \\
50.1 \\
49.8 \\
49.5\end{array}$ & 280 & 2473.97 & 17.021 & 92.4 & & & & \\
\hline $\begin{array}{l}225 \\
226 \\
227 \\
228 \\
229\end{array}$ & $\begin{array}{l}1598.72 \\
1613.47 \\
1628.27 \\
1643.12 \\
1658.02\end{array}$ & $\begin{array}{l}14.727 \\
14.776 \\
14.825 \\
14.873 \\
14.922\end{array}$ & $\begin{array}{l}49.2 \\
49.0 \\
48.7 \\
48.5 \\
48.3\end{array}$ & & & & & & & & \\
\hline $\begin{array}{l}230 \\
231 \\
232 \\
233 \\
234\end{array}$ & $\begin{array}{l}1672.97 \\
1687.96 \\
1703.00 \\
1718.09 \\
1733.23\end{array}$ & $\begin{array}{l}14.970 \\
15.018 \\
15.066 \\
15.114 \\
15.161\end{array}$ & $\begin{array}{l}48.1 \\
47.9 \\
47.8 \\
47.6 \\
47.5\end{array}$ & & & & & & & & \\
\hline $\begin{array}{l}235 \\
236 \\
237 \\
238 \\
239\end{array}$ & $\begin{array}{l}1748.41 \\
1763.65 \\
1778.93 \\
1794.25 \\
1809.63\end{array}$ & $\begin{array}{l}15.209 \\
15.256 \\
15.303 \\
15.350 \\
15.397\end{array}$ & $\begin{array}{l}47.3 \\
47.2 \\
47.0 \\
46.9 \\
46.7\end{array}$ & & & & & & & & \\
\hline 240 & 1825.04 & 15.443 & 46.5 & & & & & & & & \\
\hline
\end{tabular}




\begin{tabular}{|c|c|c|c|c|c|c|c|c|c|c|c|}
\hline $\begin{array}{l}T \\
K\end{array}$ & ${ }_{\mu v}^{E}$ & $\mu^{S}$ & $\begin{array}{l}\mathrm{dS} / \mathrm{d} T \\
\mathrm{nV} / \mathrm{K} 2\end{array}$ & $\begin{array}{l}T \\
K\end{array}$ & $\underset{\mu V}{E}$ & $\stackrel{S}{\mu V / K}$ & $\begin{array}{l}d S / d T \\
n V / K 2\end{array}$ & $\begin{array}{l}T \\
x\end{array}$ & $\begin{array}{l}E \\
\mu V\end{array}$ & $\mu^{S}{ }^{V / K}$ & $\begin{array}{l}\mathrm{dS} / \mathrm{d} T \\
\mathrm{nV} / \mathrm{K} 2\end{array}$ \\
\hline $\begin{array}{l}0 \\
1\end{array}$ & $\begin{array}{l}-1.39 \\
-1.19\end{array}$ & $\begin{array}{l}0.222 \\
0.178\end{array}$ & $\begin{array}{l}-46.0 \\
-41.9\end{array}$ & $\begin{array}{l}60 \\
61\end{array}$ & $\begin{array}{l}57.24 \\
59.18\end{array}$ & $\begin{array}{l}1.941 \\
1.945\end{array}$ & $\begin{array}{l}4.2 \\
3.1\end{array}$ & $\begin{array}{l}120 \\
121\end{array}$ & $\begin{array}{l}170.74 \\
172.61\end{array}$ & $\begin{array}{l}1.869 \\
1.870\end{array}$ & $\begin{array}{l}1 \cdot 2 \\
1 \cdot 3\end{array}$ \\
\hline $\begin{array}{l}2 \\
3 \\
4\end{array}$ & $\begin{array}{l}-1.03 \\
-0.91 \\
-0.82\end{array}$ & $\begin{array}{l}0.138 \\
0.104 \\
0.076\end{array}$ & $\begin{array}{l}-36.9 \\
-31.4 \\
-25.4\end{array}$ & $\begin{array}{l}62 \\
63 \\
64\end{array}$ & $\begin{array}{l}61.13 \\
63.08 \\
65.03\end{array}$ & $\begin{array}{l}1.947 \\
1.949 \\
1.950\end{array}$ & $\begin{array}{l}2.1 \\
1.3 \\
0.5\end{array}$ & $\begin{array}{l}122 \\
123 \\
124\end{array}$ & $\begin{array}{l}174.48 \\
176.35 \\
178.22\end{array}$ & $\begin{array}{l}1.871 \\
1.873 \\
1.874\end{array}$ & $\begin{array}{l}1.4 \\
1.5 \\
1.6\end{array}$ \\
\hline $\begin{array}{l}5 \\
6\end{array}$ & $\begin{array}{l}-0.76 \\
-0.71\end{array}$ & $\begin{array}{l}0.054 \\
0.038\end{array}$ & $\begin{array}{l}-19.1 \\
-12.6\end{array}$ & $\begin{array}{l}65 \\
66\end{array}$ & $\begin{array}{l}66.97 \\
68.92\end{array}$ & $\begin{array}{l}1.950 \\
1.949\end{array}$ & $\begin{array}{l}-0.3 \\
-0.9\end{array}$ & $\begin{array}{l}125 \\
126\end{array}$ & $\begin{array}{l}180.10 \\
181.98\end{array}$ & $\begin{array}{l}1.876 \\
1.878\end{array}$ & $\begin{array}{l}1.7 \\
1.8\end{array}$ \\
\hline $\begin{array}{l}7 \\
8 \\
9\end{array}$ & $\begin{array}{l}-0.68 \\
-0.65 \\
-0.63\end{array}$ & $\begin{array}{l}0.028 \\
0.026 \\
0.029\end{array}$ & $\begin{array}{r}-6.1 \\
0.4 \\
6.8\end{array}$ & $\begin{array}{l}67 \\
68 \\
69\end{array}$ & $\begin{array}{l}70.87 \\
72.82 \\
74.77\end{array}$ & $\begin{array}{l}1.948 \\
1.946 \\
1.944\end{array}$ & $\begin{array}{l}-1.5 \\
-2.0 \\
-2.4\end{array}$ & $\begin{array}{l}127 \\
128 \\
129\end{array}$ & $\begin{array}{l}183.85 \\
185.73 \\
187.62\end{array}$ & $\begin{array}{l}1.879 \\
1.881 \\
1.883\end{array}$ & $\begin{array}{l}1 \cdot 9 \\
2 \cdot 0 \\
2 \cdot 1\end{array}$ \\
\hline $\begin{array}{l}10 \\
11\end{array}$ & $\begin{array}{l}-0.59 \\
-0.55\end{array}$ & $\begin{array}{l}0.039 \\
0.055\end{array}$ & $\begin{array}{l}12.9 \\
18.8\end{array}$ & $\begin{array}{l}70 \\
71\end{array}$ & $\begin{array}{l}76.71 \\
78.65\end{array}$ & $\begin{array}{l}1.942 \\
1.939\end{array}$ & $\begin{array}{l}-2.8 \\
-3.1\end{array}$ & $\begin{array}{l}130 \\
131\end{array}$ & $\begin{array}{l}189.50 \\
191.39\end{array}$ & $\begin{array}{l}1.885 \\
1.888\end{array}$ & $\begin{array}{l}2.2 \\
2.3\end{array}$ \\
\hline $\begin{array}{l}12 \\
13 \\
14\end{array}$ & $\begin{array}{l}-0.48 \\
-0.39 \\
-0.27\end{array}$ & $\begin{array}{l}0.077 \\
0.104 \\
0.136\end{array}$ & $\begin{array}{l}24.4 \\
29.7 \\
34.6\end{array}$ & $\begin{array}{l}72 \\
73 \\
74\end{array}$ & $\begin{array}{l}80.59 \\
82.52 \\
84.45\end{array}$ & $\begin{array}{l}1.935 \\
1.932 \\
1.928\end{array}$ & $\begin{array}{l}-3.3 \\
-3.5 \\
-3.7\end{array}$ & $\begin{array}{l}132 \\
133 \\
134\end{array}$ & $\begin{array}{l}193.28 \\
195.17 \\
197.06\end{array}$ & $\begin{array}{l}1.890 \\
1.893 \\
1.895\end{array}$ & $\begin{array}{l}2.5 \\
2.6 \\
2.7\end{array}$ \\
\hline $\begin{array}{l}15 \\
16 \\
17 \\
18 \\
19\end{array}$ & $\begin{array}{r}-0.12 \\
0.07 \\
0.31 \\
0.59 \\
0.93\end{array}$ & $\begin{array}{l}0.173 \\
0.214 \\
0.259 \\
0.307 \\
0.359\end{array}$ & $\begin{array}{l}39.1 \\
43.2 \\
46.8 \\
50.1 \\
52.9\end{array}$ & $\begin{array}{l}75 \\
76 \\
77 \\
78 \\
79\end{array}$ & $\begin{array}{l}86.38 \\
88.30 \\
90.22 \\
92.13 \\
94.04\end{array}$ & $\begin{array}{l}1.925 \\
1.921 \\
1.917 \\
1.913 \\
1.909\end{array}$ & $\begin{array}{l}-3.8 \\
-3.8 \\
-3.9 \\
-3.9 \\
-3.8\end{array}$ & $\begin{array}{l}135 \\
136 \\
137 \\
138 \\
139\end{array}$ & $\begin{array}{l}198.96 \\
200.86 \\
202.76 \\
204.67 \\
206.57\end{array}$ & $\begin{array}{l}1.898 \\
1.901 \\
1.904 \\
1.907 \\
1.911\end{array}$ & $\begin{array}{l}2.9 \\
3.0 \\
3.1 \\
3.3 \\
3.4\end{array}$ \\
\hline $\begin{array}{l}20 \\
21 \\
22 \\
23 \\
24\end{array}$ & $\begin{array}{l}1.31 \\
1.75 \\
2.25 \\
2.81 \\
3.43\end{array}$ & $\begin{array}{l}0.413 \\
0.469 \\
0.528 \\
0.587 \\
0.648\end{array}$ & $\begin{array}{l}55.3 \\
57.3 \\
58.9 \\
60.1 \\
61.0\end{array}$ & $\begin{array}{l}80 \\
81 \\
82 \\
83 \\
84\end{array}$ & $\begin{array}{r}95.95 \\
97.86 \\
99.76 \\
101.65 \\
103.55\end{array}$ & $\begin{array}{l}1.906 \\
1.902 \\
1.898 \\
1.895 \\
1.891\end{array}$ & $\begin{array}{l}-3.8 \\
-3.7 \\
-3.6 \\
-3.4 \\
-3.3\end{array}$ & $\begin{array}{l}140 \\
141 \\
142 \\
143 \\
144\end{array}$ & $\begin{array}{l}208 \cdot 49 \\
210.40 \\
212.32 \\
214.25 \\
216.17\end{array}$ & $\begin{array}{l}1.914 \\
1.918 \\
1.922 \\
1.926 \\
1.930\end{array}$ & $\begin{array}{l}3 \cdot 6 \\
3.7 \\
3 \cdot 9 \\
4 \cdot 1 \\
4.2\end{array}$ \\
\hline $\begin{array}{l}25 \\
26 \\
27 \\
28 \\
29\end{array}$ & $\begin{array}{l}4.10 \\
4.84 \\
5.64 \\
6.51 \\
7.43\end{array}$ & $\begin{array}{l}0.709 \\
0.771 \\
0.832 \\
0.894 \\
0.954\end{array}$ & $\begin{array}{l}61 \cdot 5 \\
61 \cdot 7 \\
61 \cdot 5 \\
61 \cdot 1 \\
60.4\end{array}$ & $\begin{array}{l}85 \\
86 \\
87 \\
88 \\
89\end{array}$ & $\begin{array}{l}105.44 \\
107.32 \\
109.21 \\
111.09 \\
112.96\end{array}$ & $\begin{array}{l}1.888 \\
1.885 \\
1.882 \\
1.880 \\
1.877\end{array}$ & $\begin{array}{l}-3.1 \\
-3.0 \\
-2.8 \\
-2.6 \\
-2.4\end{array}$ & $\begin{array}{l}145 \\
146 \\
147 \\
148 \\
149\end{array}$ & $\begin{array}{l}218.11 \\
220.04 \\
221.98 \\
223.93 \\
225.88\end{array}$ & $\begin{array}{l}1.934 \\
1.938 \\
1.943 \\
1.948 \\
1.953\end{array}$ & $\begin{array}{l}4 \cdot 4 \\
4 \cdot 5 \\
4 \cdot 7 \\
4.8 \\
4.9\end{array}$ \\
\hline $\begin{array}{l}30 \\
31 \\
32 \\
33 \\
34\end{array}$ & $\begin{array}{r}8.42 \\
9.46 \\
10.56 \\
11.72 \\
12.94\end{array}$ & $\begin{array}{l}1.014 \\
1.073 \\
1.131 \\
1.187 \\
1.242\end{array}$ & $\begin{array}{l}59.5 \\
58.3 \\
57.0 \\
55.4 \\
53.7\end{array}$ & $\begin{array}{l}90 \\
91 \\
92 \\
93 \\
94\end{array}$ & $\begin{array}{l}114.84 \\
116.71 \\
118.59 \\
120.46 \\
122.32\end{array}$ & $\begin{array}{l}1.875 \\
1.872 \\
1.870 \\
1.869 \\
1.867\end{array}$ & $\begin{array}{l}-2.3 \\
-2.1 \\
-1.9 \\
-1.7 \\
-1.5\end{array}$ & $\begin{array}{l}150 \\
151 \\
152 \\
153 \\
154\end{array}$ & $\begin{array}{l}227.83 \\
229.79 \\
231.76 \\
233.73 \\
235.71\end{array}$ & $\begin{array}{l}1.958 \\
1.963 \\
1.968 \\
1.974 \\
1.979\end{array}$ & $\begin{array}{l}5.1 \\
5.2 \\
5.4 \\
5.5 \\
5.6\end{array}$ \\
\hline $\begin{array}{l}35 \\
36 \\
37 \\
38 \\
39\end{array}$ & $\begin{array}{l}14.20 \\
15.52 \\
16.89 \\
18.31 \\
19.77\end{array}$ & $\begin{array}{l}1.294 \\
1.345 \\
1.394 \\
1.441 \\
1.486\end{array}$ & $\begin{array}{l}51.9 \\
49.9 \\
47.9 \\
45.8 \\
43.6\end{array}$ & $\begin{array}{l}95 \\
96 \\
97 \\
98 \\
99\end{array}$ & $\begin{array}{l}124.19 \\
126.05 \\
127.92 \\
129.78 \\
131.64\end{array}$ & $\begin{array}{l}1.866 \\
1.864 \\
1.863 \\
1.862 \\
1.861\end{array}$ & $\begin{array}{l}-1.4 \\
-1.2 \\
-1.0 \\
-0.9 \\
-0.7\end{array}$ & $\begin{array}{l}155 \\
156 \\
157 \\
158 \\
159\end{array}$ & $\begin{array}{l}237.69 \\
239.68 \\
241.67 \\
243.67 \\
245.67\end{array}$ & $\begin{array}{l}1.985 \\
1.990 \\
1.996 \\
2.002 \\
2.008\end{array}$ & $\begin{array}{l}5.7 \\
5.8 \\
5.9 \\
6.0 \\
6.1\end{array}$ \\
\hline $\begin{array}{l}40 \\
41 \\
42 \\
43 \\
44\end{array}$ & $\begin{array}{l}21.28 \\
22.83 \\
24.42 \\
26.04 \\
27.70\end{array}$ & $\begin{array}{l}1.528 \\
1.568 \\
1.606 \\
1.642 \\
1.675\end{array}$ & $\begin{array}{l}41.4 \\
39.1 \\
36.8 \\
34.5 \\
32.3\end{array}$ & $\begin{array}{l}100 \\
101 \\
102 \\
103 \\
104\end{array}$ & $\begin{array}{l}133.50 \\
135.36 \\
137.22 \\
139.08 \\
140.94\end{array}$ & $\begin{array}{l}1.861 \\
1.860 \\
1.860 \\
1.859 \\
1.859\end{array}$ & $\begin{array}{l}-0.6 \\
-0.5 \\
-0.3 \\
-0.2 \\
-0.1\end{array}$ & $\begin{array}{l}160 \\
161 \\
162 \\
163 \\
164\end{array}$ & $\begin{array}{l}247.69 \\
249.70 \\
251.73 \\
253.76 \\
255.79\end{array}$ & $\begin{array}{l}2.014 \\
2.021 \\
2.027 \\
2.033 \\
2.040\end{array}$ & $\begin{array}{l}6.2 \\
6.2 \\
6.3 \\
6.4 \\
6.4\end{array}$ \\
\hline $\begin{array}{l}45 \\
46 \\
47 \\
48 \\
49\end{array}$ & $\begin{array}{l}29.39 \\
31.11 \\
32.86 \\
34.64 \\
36.44\end{array}$ & $\begin{array}{l}1.707 \\
1.736 \\
1.762 \\
1.787 \\
1.809\end{array}$ & $\begin{array}{l}30.0 \\
27.8 \\
25.7 \\
23.6 \\
21.5\end{array}$ & $\begin{array}{l}105 \\
106 \\
107 \\
108 \\
109\end{array}$ & $\begin{array}{l}142.80 \\
144.66 \\
146.52 \\
148.38 \\
150.24\end{array}$ & $\begin{array}{r}1.859 \\
1.859 \\
1.859 \\
1.860 \\
1.860\end{array}$ & $\begin{array}{r}-0.0 \\
0.1 \\
0.2 \\
0.3 \\
0.4\end{array}$ & $\begin{array}{l}165 \\
166 \\
167 \\
168 \\
169\end{array}$ & $\begin{array}{l}257.84 \\
259.89 \\
261.94 \\
264.00 \\
266.07\end{array}$ & $\begin{array}{l}2.046 \\
2.053 \\
2.059 \\
2.066 \\
2.072\end{array}$ & $\begin{array}{l}6.5 \\
6.5 \\
6.5 \\
6.5 \\
6.6\end{array}$ \\
\hline $\begin{array}{l}50 \\
51 \\
52 \\
53 \\
54\end{array}$ & $\begin{array}{l}38.26 \\
40.10 \\
41.95 \\
43.82 \\
45.71\end{array}$ & $\begin{array}{l}1.830 \\
1.848 \\
1.865 \\
1.880 \\
1.893\end{array}$ & $\begin{array}{l}19.5 \\
17.6 \\
15.8 \\
14.0 \\
12.3\end{array}$ & $\begin{array}{ll}110 \\
111 \\
112 \\
113 \\
114\end{array}$ & $\begin{array}{l}152.10 \\
153.96 \\
155.82 \\
157.68 \\
159.55\end{array}$ & $\begin{array}{l}1.860 \\
1.861 \\
1.861 \\
1.862 \\
1.863\end{array}$ & $\begin{array}{l}0.5 \\
0.5 \\
0.6 \\
0.7 \\
0.8\end{array}$ & $\begin{array}{l}170 \\
171 \\
172 \\
173 \\
174\end{array}$ & $\begin{array}{l}268 \cdot 15 \\
270 \cdot 23 \\
272.32 \\
274.41 \\
276.52\end{array}$ & $\begin{array}{l}2.079 \\
2.085 \\
2.092 \\
2.098 \\
2 \cdot 105\end{array}$ & $\begin{array}{l}6.6 \\
6.6 \\
6.6 \\
6.6 \\
6.6\end{array}$ \\
\hline $\begin{array}{l}55 \\
56 \\
57 \\
58 \\
59\end{array}$ & $\begin{array}{l}47.61 \\
49.52 \\
51.44 \\
53.37 \\
55.30\end{array}$ & $\begin{array}{l}1.905 \\
1.915 \\
1.923 \\
1.930 \\
1.936\end{array}$ & $\begin{array}{r}10.7 \\
9.2 \\
7.8 \\
6.5 \\
5.3\end{array}$ & $\begin{array}{l}115 \\
116 \\
117 \\
118 \\
119\end{array}$ & $\begin{array}{l}161.41 \\
163.27 \\
165.14 \\
167.00 \\
168.87\end{array}$ & $\begin{array}{l}1.864 \\
1.864 \\
1.865 \\
1.866 \\
1.867\end{array}$ & $\begin{array}{l}0.8 \\
0.9 \\
1.0 \\
1.1 \\
1.1\end{array}$ & $\begin{array}{l}175 \\
176 \\
177 \\
178 \\
179\end{array}$ & $\begin{array}{l}278.62 \\
250.74 \\
282.86 \\
284.99 \\
287.12\end{array}$ & $\begin{array}{l}2.112 \\
2.118 \\
2.125 \\
2.131 \\
2.138\end{array}$ & $\begin{array}{l}6.5 \\
6.5 \\
6.5 \\
6.5 \\
6.5\end{array}$ \\
\hline 60 & $57 \cdot 24$ & 1.941 & $4 \cdot 2$ & 120 & 170.74 & 1.869 & 1.2 & 180 & 289.26 & 2.144 & 6.5 \\
\hline
\end{tabular}




\begin{tabular}{|c|c|c|c|c|c|c|c|c|c|c|c|}
\hline $\begin{array}{l}T \\
K\end{array}$ & $\underset{\mu V}{E}$ & $\mu \stackrel{S}{V} / K$ & $\begin{array}{l}d s / d T \\
n V / K^{2}\end{array}$ & $\begin{array}{l}T \\
K\end{array}$ & $\underset{\mu V}{E}$ & $\stackrel{s}{\mu v / K}$ & $\begin{array}{l}d S / d T \\
n V / K^{2}\end{array}$ & $\begin{array}{l}T \\
K\end{array}$ & $\underset{\mu V}{E}$ & $\stackrel{s}{\mu v / k}$ & $\begin{array}{l}d s / d J \\
n v / k^{2}\end{array}$ \\
\hline $\begin{array}{l}180 \\
181 \\
182 \\
183 \\
184\end{array}$ & $\begin{array}{l}289.26 \\
291.41 \\
293.56 \\
295.72 \\
297.89\end{array}$ & $\begin{array}{l}2.144 \\
2.151 \\
2.157 \\
2.163 \\
2.170\end{array}$ & $\begin{array}{l}6.5 \\
6.5 \\
6.4 \\
6.4 \\
6.4\end{array}$ & $\begin{array}{l}240 \\
241 \\
242 \\
243 \\
244\end{array}$ & $\begin{array}{l}431.13 \\
433.74 \\
436.36 \\
438.98 \\
441.61\end{array}$ & $\begin{array}{l}2.608 \\
2.615 \\
2.621 \\
2.628 \\
2.634\end{array}$ & $\begin{array}{l}6.8 \\
6.6 \\
6.5 \\
6.3 \\
6.3\end{array}$ & & & & \\
\hline $\begin{array}{l}185 \\
186 \\
187 \\
188 \\
189\end{array}$ & $\begin{array}{l}300.06 \\
302.24 \\
304.43 \\
306.62 \\
308.82\end{array}$ & $\begin{array}{l}2 \cdot 176 \\
2.183 \\
2 \cdot 189 \\
2.196 \\
2.202\end{array}$ & $\begin{array}{l}6.4 \\
6.4 \\
6.4 \\
6.4 \\
6.5\end{array}$ & $\begin{array}{l}245 \\
246 \\
247 \\
248 \\
249\end{array}$ & $\begin{array}{l}444.25 \\
446.89 \\
449.54 \\
452.20 \\
454.86\end{array}$ & $\begin{array}{l}2.640 \\
2.647 \\
2.653 \\
2.659 \\
2.665\end{array}$ & $\begin{array}{l}6.2 \\
6.2 \\
6.2 \\
6.2 \\
6.4\end{array}$ & & & & \\
\hline $\begin{array}{l}190 \\
191 \\
192 \\
193 \\
194\end{array}$ & $\begin{array}{l}311.03 \\
313.24 \\
315.46 \\
317.68 \\
319.91\end{array}$ & $\begin{array}{l}2 \cdot 209 \\
2.215 \\
2.222 \\
2 \cdot 228 \\
2.235\end{array}$ & $\begin{array}{l}6.5 \\
6.5 \\
6.6 \\
6.6 \\
6.7\end{array}$ & $\begin{array}{l}250 \\
251 \\
252 \\
253 \\
254\end{array}$ & $\begin{array}{l}457.53 \\
460.21 \\
462.89 \\
465.58 \\
468.27\end{array}$ & $\begin{array}{l}2.672 \\
2.678 \\
2.685 \\
2.692 \\
2.700\end{array}$ & $\begin{array}{l}6.5 \\
6.7 \\
7.0 \\
7 \cdot 3 \\
7.7\end{array}$ & & & & \\
\hline $\begin{array}{l}200 \\
201 \\
202 \\
203 \\
204\end{array}$ & $\begin{array}{l}333 \cdot 44 \\
335.72 \\
338.01 \\
340.30 \\
342.61\end{array}$ & $\begin{array}{l}2 \cdot 276 \\
2.283 \\
2.291 \\
2.298 \\
2.306\end{array}$ & $\begin{array}{l}7.1 \\
7.2 \\
7.4 \\
7.5 \\
7.6\end{array}$ & $\begin{array}{l}260 \\
261 \\
262 \\
263 \\
264\end{array}$ & $\begin{array}{l}484 \cdot 63 \\
487 \cdot 39 \\
490.16 \\
492 \cdot 94 \\
495.74\end{array}$ & $\begin{array}{l}2.755 \\
2.766 \\
2.777 \\
2.790 \\
2.802\end{array}$ & $\begin{array}{l}10.8 \\
11.4 \\
11.9 \\
12.4 \\
12.9\end{array}$ & & & & \\
\hline $\begin{array}{l}205 \\
206 \\
207 \\
208 \\
209\end{array}$ & $\begin{array}{l}344 \cdot 91 \\
347 \cdot 23 \\
349 \cdot 56 \\
351 \cdot 89 \\
354 \cdot 23\end{array}$ & $\begin{array}{l}2 \cdot 313 \\
2 \cdot 321 \\
2 \cdot 329 \\
2 \cdot 337 \\
2 \cdot 345\end{array}$ & $\begin{array}{l}7.7 \\
7.8 \\
8.0 \\
8.1 \\
8.2\end{array}$ & $\begin{array}{l}265 \\
266 \\
267 \\
268 \\
269\end{array}$ & $\begin{array}{l}498.55 \\
501.37 \\
504.20 \\
507.05 \\
509.91\end{array}$ & $\begin{array}{l}2.815 \\
2.829 \\
2.842 \\
2.855 \\
2.868\end{array}$ & $\begin{array}{l}13.2 \\
13.3 \\
13.3 \\
12.9 \\
12.3\end{array}$ & & & & \\
\hline $\begin{array}{l}210 \\
211 \\
212 \\
213 \\
214\end{array}$ & $\begin{array}{l}356.58 \\
358.94 \\
361.30 \\
363.68 \\
366.06\end{array}$ & $\begin{array}{l}2.353 \\
2.362 \\
2.370 \\
2.379 \\
2.387\end{array}$ & $\begin{array}{l}8.3 \\
8.4 \\
8.6 \\
8.7 \\
8.8\end{array}$ & $\begin{array}{l}270 \\
271 \\
272 \\
273 \\
274\end{array}$ & $\begin{array}{l}512.79 \\
515.67 \\
518.57 \\
521.47 \\
524.37\end{array}$ & $\begin{array}{l}2.879 \\
2.890 \\
2.899 \\
2.905 \\
2.908\end{array}$ & $\begin{array}{r}11.2 \\
9.7 \\
7.7 \\
4.9 \\
1.4\end{array}$ & & & & \\
\hline $\begin{array}{l}215 \\
216 \\
217 \\
218 \\
219\end{array}$ & $\begin{array}{l}368.45 \\
370.85 \\
373.26 \\
375.68 \\
378.11\end{array}$ & $\begin{array}{l}2.396 \\
2.405 \\
2.414 \\
2.423 \\
2.432\end{array}$ & $\begin{array}{l}8.9 \\
8.9 \\
9.0 \\
9.1 \\
9.1\end{array}$ & $\begin{array}{l}275 \\
276 \\
277 \\
278 \\
279\end{array}$ & $\begin{array}{l}527.28 \\
530.19 \\
533.08 \\
535.97 \\
538.82\end{array}$ & $\begin{array}{l}2.908 \\
2.902 \\
2.890 \\
2.871 \\
2.843\end{array}$ & $\begin{array}{r}-3 \cdot 1 \\
-8 \cdot 6 \\
-15 \cdot 3 \\
-23.4 \\
-33 \cdot 1\end{array}$ & & & & \\
\hline $\begin{array}{l}220 \\
221 \\
222 \\
223 \\
224\end{array}$ & $\begin{array}{l}380.55 \\
382.99 \\
385.45 \\
387.91 \\
390.39\end{array}$ & $\begin{array}{l}2.441 \\
2.451 \\
2.460 \\
2.469 \\
2.478\end{array}$ & $\begin{array}{l}9.1 \\
9.2 \\
9.2 \\
9 \cdot 1 \\
9.1\end{array}$ & 280 & 541.65 & 2.804 & $-44 \cdot 6$ & & & & \\
\hline $\begin{array}{l}225 \\
226 \\
227 \\
228 \\
229\end{array}$ & $\begin{array}{l}392 \cdot 87 \\
395 \cdot 36 \\
397 \cdot 86 \\
400 \cdot 37 \\
402 \cdot 89\end{array}$ & $\begin{array}{l}2.487 \\
2.496 \\
2.505 \\
2.514 \\
2.523\end{array}$ & $\begin{array}{l}9.1 \\
9.0 \\
8.9 \\
8.8 \\
8.7\end{array}$ & & & & & & & & \\
\hline $\begin{array}{l}230 \\
231 \\
232 \\
233 \\
234\end{array}$ & $\begin{array}{l}405.42 \\
407.95 \\
410.50 \\
413.05 \\
415.61\end{array}$ & $\begin{array}{l}2.531 \\
2.540 \\
2.548 \\
2.556 \\
2.564\end{array}$ & $\begin{array}{l}8.6 \\
8.4 \\
8.2 \\
8.1 \\
7.9\end{array}$ & & & & & & & & \\
\hline $\begin{array}{l}235 \\
236 \\
237 \\
238 \\
239\end{array}$ & $\begin{array}{l}418 \cdot 18 \\
420 \cdot 75 \\
423 \cdot 34 \\
425.93 \\
428.52\end{array}$ & $\begin{array}{l}2.572 \\
2.580 \\
2.587 \\
2.594 \\
2.601\end{array}$ & $\begin{array}{l}7.7 \\
7.5 \\
7.3 \\
7.1 \\
6.9\end{array}$ & & & & & & & & \\
\hline $24 n$ & $431 \cdot 13$ & $2 \cdot 608$ & 6.8 & & & & & & & & \\
\hline
\end{tabular}




\begin{tabular}{|c|c|c|c|c|c|c|c|c|c|c|c|}
\hline $\begin{array}{l}T \\
\text { K }\end{array}$ & $\underset{\mu V}{E}$ & $\stackrel{S}{\mu V / K}$ & $\begin{array}{l}d 5 / d T \\
n V / K^{2}\end{array}$ & $\begin{array}{l}T \\
K\end{array}$ & $\begin{array}{c}E \\
\mu v\end{array}$ & $\stackrel{S}{\mu V / K}$ & $\begin{array}{l}d S / d T \\
n V / K 2\end{array}$ & $\begin{array}{l}T \\
K\end{array}$ & $\begin{array}{c}\mathrm{E} \\
\mu \mathrm{V}\end{array}$ & $\stackrel{S}{\mu V / K}$ & $\begin{array}{l}d s / d T \\
n v / K^{2}\end{array}$ \\
\hline $\begin{array}{l}0 \\
1 \\
2 \\
3 \\
4\end{array}$ & $\begin{array}{r}0.00 \\
-1.11 \\
-1.99 \\
-2.63 \\
-3.07\end{array}$ & $\begin{array}{l}-1.242 \\
-0.989 \\
-0.756 \\
-0.539 \\
-0.336\end{array}$ & $\begin{array}{l}264.1 \\
242.6 \\
224.6 \\
209.7 \\
197.6\end{array}$ & $\begin{array}{l}60 \\
61 \\
62 \\
63 \\
64\end{array}$ & $\begin{array}{l}210.61 \\
217.04 \\
223.48 \\
229.92 \\
236.36\end{array}$ & $\begin{array}{l}6.421 \\
6.432 \\
6.440 \\
6.443 \\
6.443\end{array}$ & $\begin{array}{r}13.2 \\
9.3 \\
5.5 \\
1.8 \\
-1.8\end{array}$ & $\begin{array}{l}120 \\
121 \\
122 \\
123 \\
124\end{array}$ & $\begin{array}{l}537.70 \\
541.52 \\
545.28 \\
548.98 \\
552.62\end{array}$ & $\begin{array}{l}3.850 \\
3.790 \\
3.730 \\
3.670 \\
3.609\end{array}$ & $\begin{array}{l}-60.3 \\
-60.2 \\
-60.2 \\
-60.2 \\
-60.1\end{array}$ \\
\hline $\begin{array}{l}5 \\
6 \\
7 \\
8 \\
9\end{array}$ & $\begin{array}{l}-3 \cdot 31 \\
-3 \cdot 36 \\
-3.23 \\
-2.92 \\
-2.45\end{array}$ & $\begin{array}{r}-0.143 \\
0.041 \\
0.217 \\
0.389 \\
0.557\end{array}$ & $\begin{array}{l}187.8 \\
180.0 \\
174.0 \\
169.4 \\
166.1\end{array}$ & $\begin{array}{l}65 \\
66 \\
67 \\
68 \\
69\end{array}$ & $\begin{array}{l}242.80 \\
249.24 \\
255.67 \\
262.08 \\
268.49\end{array}$ & $\begin{array}{l}6.440 \\
6.433 \\
6.423 \\
6.410 \\
6.394\end{array}$ & $\begin{array}{r}-5.2 \\
-8.5 \\
-11.6 \\
-14.6 \\
-17.5\end{array}$ & $\begin{array}{l}125 \\
126 \\
127 \\
128 \\
129\end{array}$ & $\begin{array}{l}556.20 \\
559.72 \\
563.18 \\
566.58 \\
569.92\end{array}$ & $\begin{array}{l}3.549 \\
3.489 \\
3.429 \\
3.370 \\
3.310\end{array}$ & $\begin{array}{l}-60.1 \\
-60.0 \\
-59.9 \\
-59.8 \\
-59.7\end{array}$ \\
\hline $\begin{array}{l}10 \\
11 \\
12 \\
13 \\
14\end{array}$ & $\begin{array}{r}-1.81 \\
-1.01 \\
-0.04 \\
1.08 \\
2.37\end{array}$ & $\begin{array}{l}0.721 \\
0.884 \\
1.046 \\
1.207 \\
1.368\end{array}$ & $\begin{array}{l}163.7 \\
162.2 \\
161.3 \\
160.9 \\
160.8\end{array}$ & $\begin{array}{l}70 \\
71 \\
72 \\
73 \\
74\end{array}$ & $\begin{array}{l}274.87 \\
281.24 \\
287.58 \\
293.89 \\
300.18\end{array}$ & $\begin{array}{l}6.375 \\
6.353 \\
6.329 \\
6.303 \\
6.274\end{array}$ & $\begin{array}{l}-20.2 \\
-22.8 \\
-25.3 \\
-27.7 \\
-29.9\end{array}$ & $\begin{array}{l}130 \\
131 \\
132 \\
133 \\
134\end{array}$ & $\begin{array}{l}573.20 \\
576.42 \\
579.58 \\
582.68 \\
585.72\end{array}$ & $\begin{array}{l}3.250 \\
3.191 \\
3.131 \\
3.072 \\
3.013\end{array}$ & $\begin{array}{l}-59.6 \\
-59.4 \\
-59.3 \\
-59.1 \\
-59.0\end{array}$ \\
\hline $\begin{array}{l}15 \\
16 \\
17 \\
18 \\
19\end{array}$ & $\begin{array}{r}3.82 \\
5.43 \\
7.20 \\
9.13 \\
11.23\end{array}$ & $\begin{array}{l}1.529 \\
1.690 \\
1.851 \\
2.013 \\
2.175\end{array}$ & $\begin{array}{l}161.0 \\
161.3 \\
161.6 \\
161.9 \\
162.2\end{array}$ & $\begin{array}{l}75 \\
76 \\
77 \\
78 \\
79\end{array}$ & $\begin{array}{l}306.44 \\
312.67 \\
318.86 \\
325.02 \\
331.13\end{array}$ & $\begin{array}{l}6.243 \\
6.210 \\
6.175 \\
6.138 \\
6.100\end{array}$ & $\begin{array}{l}-32.0 \\
-34.0 \\
-35.9 \\
-37.7 \\
-39.3\end{array}$ & $\begin{array}{l}135 \\
136 \\
137 \\
138 \\
139\end{array}$ & $\begin{array}{l}588.71 \\
591.63 \\
594.50 \\
597.30 \\
600.05\end{array}$ & $\begin{array}{l}2.954 \\
2.895 \\
2.837 \\
2.779 \\
2.721\end{array}$ & $\begin{array}{l}-58.8 \\
-58.6 \\
-58.4 \\
-58.2 \\
-58.0\end{array}$ \\
\hline $\begin{array}{l}20 \\
21 \\
22 \\
23 \\
24\end{array}$ & $\begin{array}{l}13.48 \\
15.90 \\
18.48 \\
21.22 \\
24.13\end{array}$ & $\begin{array}{l}2.337 \\
2.500 \\
2.662 \\
2.823 \\
2.984\end{array}$ & $\begin{array}{l}162.2 \\
162.1 \\
161.8 \\
161.2 \\
160.3\end{array}$ & $\begin{array}{l}80 \\
81 \\
82 \\
83 \\
84\end{array}$ & $\begin{array}{l}337.21 \\
343.25 \\
349.25 \\
355.20 \\
361.11\end{array}$ & $\begin{array}{l}6.060 \\
6.018 \\
5.975 \\
5.930 \\
5.885\end{array}$ & $\begin{array}{l}-40.9 \\
-42.4 \\
-43.8 \\
-45.1 \\
-46.3\end{array}$ & $\begin{array}{l}140 \\
141 \\
142 \\
143 \\
144\end{array}$ & $\begin{array}{l}602.75 \\
605.38 \\
607.96 \\
610.47 \\
612.94\end{array}$ & $\begin{array}{l}2.663 \\
2.605 \\
2.548 \\
2.490 \\
2.433\end{array}$ & $\begin{array}{l}-57.2 \\
-57.6 \\
-57.3 \\
-57.1 \\
-56.8\end{array}$ \\
\hline $\begin{array}{l}25 \\
26 \\
27 \\
28 \\
29\end{array}$ & $\begin{array}{l}27.19 \\
30.41 \\
33.79 \\
37.33 \\
41.02\end{array}$ & $\begin{array}{l}3.144 \\
3.302 \\
3.459 \\
3.614 \\
3.767\end{array}$ & $\begin{array}{l}159.1 \\
157.7 \\
155.9 \\
153.9 \\
151.5\end{array}$ & $\begin{array}{l}85 \\
86 \\
87 \\
88 \\
89\end{array}$ & $\begin{array}{l}366.97 \\
372.79 \\
378.55 \\
384.27 \\
389.93\end{array}$ & $\begin{array}{l}5.838 \\
5.790 \\
5.741 \\
5.691 \\
5.640\end{array}$ & $\begin{array}{l}-47.4 \\
-48.5 \\
-49.5 \\
-50.4 \\
-51.2\end{array}$ & $\begin{array}{l}145 \\
146 \\
147 \\
148 \\
149\end{array}$ & $\begin{array}{l}615.34 \\
617.69 \\
619.98 \\
622.22 \\
624.40\end{array}$ & $\begin{array}{l}2.377 \\
2.320 \\
2.264 \\
2.208 \\
2.152\end{array}$ & $\begin{array}{l}-56.6 \\
-56.3 \\
-56.1 \\
-55.8 \\
-55.5\end{array}$ \\
\hline $\begin{array}{l}30 \\
31 \\
32 \\
33 \\
34\end{array}$ & $\begin{array}{l}44.86 \\
48.85 \\
52.99 \\
57.27 \\
61.69\end{array}$ & $\begin{array}{l}3.917 \\
4.064 \\
4.208 \\
4.349 \\
4.487\end{array}$ & $\begin{array}{l}148.8 \\
145.9 \\
142.7 \\
139.2 \\
135.6\end{array}$ & $\begin{array}{l}90 \\
91 \\
92 \\
93 \\
94\end{array}$ & $\begin{array}{l}395.55 \\
401.11 \\
406.62 \\
412.07 \\
417.48\end{array}$ & $\begin{array}{l}5.588 \\
5.536 \\
5.483 \\
5.429 \\
5.375\end{array}$ & $\begin{array}{l}-52.0 \\
-52.8 \\
-53.5 \\
-54.1 \\
-54.7\end{array}$ & $\begin{array}{l}150 \\
151 \\
152 \\
153 \\
154\end{array}$ & $\begin{array}{l}626.52 \\
628.59 \\
630.61 \\
632.57 \\
634.47\end{array}$ & $\begin{array}{l}2.097 \\
2.042 \\
1.987 \\
1.933 \\
1.878\end{array}$ & $\begin{array}{l}-55.2 \\
-55.0 \\
-54.7 \\
-54.4 \\
-54.1\end{array}$ \\
\hline $\begin{array}{l}35 \\
36 \\
37 \\
38 \\
39\end{array}$ & $\begin{array}{l}66.24 \\
70.93 \\
75.74 \\
80.68 \\
85.73\end{array}$ & $\begin{array}{l}4.620 \\
4.750 \\
4.875 \\
4.996 \\
5.113\end{array}$ & $\begin{array}{l}131.6 \\
127.5 \\
123.2 \\
118.7 \\
114.1\end{array}$ & $\begin{array}{l}95 \\
96 \\
97 \\
98 \\
99\end{array}$ & $\begin{array}{l}422.82 \\
428.12 \\
433.35 \\
438.53 \\
443.66\end{array}$ & $\begin{array}{l}5.320 \\
5.264 \\
5.208 \\
5.152 \\
5.095\end{array}$ & $\begin{array}{l}-55.2 \\
-55.7 \\
-56.2 \\
-56.6 \\
-57.0\end{array}$ & $\begin{array}{l}155 \\
156 \\
157 \\
158 \\
159\end{array}$ & $\begin{array}{l}636.32 \\
638.12 \\
639.86 \\
641.56 \\
643.19\end{array}$ & $\begin{array}{l}1.824 \\
1.771 \\
1.717 \\
1.664 \\
1.611\end{array}$ & $\begin{array}{l}-53.8 \\
-53.5 \\
-53.3 \\
-53.0 \\
-52.7\end{array}$ \\
\hline $\begin{array}{l}40 \\
41 \\
42 \\
43 \\
44\end{array}$ & $\begin{array}{r}90.90 \\
96.18 \\
101.56 \\
107.04 \\
112.62\end{array}$ & $\begin{array}{l}5.225 \\
5.332 \\
5.434 \\
5.531 \\
5.623\end{array}$ & $\begin{array}{r}109.4 \\
104.5 \\
99.6 \\
94.6 \\
89.5\end{array}$ & $\begin{array}{l}100 \\
101 \\
102 \\
103 \\
104\end{array}$ & $\begin{array}{l}448.72 \\
453.73 \\
458.68 \\
463.58 \\
468.41\end{array}$ & $\begin{array}{l}5.038 \\
4.980 \\
4.923 \\
4.864 \\
4.806\end{array}$ & $\begin{array}{l}-57.4 \\
-57.7 \\
-58.0 \\
-58.3 \\
-58.6\end{array}$ & $\begin{array}{l}160 \\
161 \\
162 \\
163 \\
164\end{array}$ & $\begin{array}{l}644.78 \\
646.31 \\
647.79 \\
649.22 \\
650.60\end{array}$ & $\begin{array}{l}1.559 \\
1.506 \\
1.454 \\
1.403 \\
1.351\end{array}$ & $\begin{array}{l}-52.4 \\
-52.2 \\
-51.9 \\
-51.6 \\
-51.4\end{array}$ \\
\hline $\begin{array}{l}45 \\
46 \\
47 \\
48 \\
49\end{array}$ & $\begin{array}{l}118.29 \\
124.04 \\
129.87 \\
135.77 \\
141.75\end{array}$ & $\begin{array}{l}5.710 \\
5.792 \\
5.868 \\
5.940 \\
6.007\end{array}$ & $\begin{array}{l}84 \cdot 4 \\
79 \cdot 3 \\
74 \cdot 2 \\
69 \cdot 1 \\
64 \cdot 0\end{array}$ & $\begin{array}{l}105 \\
106 \\
107 \\
108 \\
109\end{array}$ & $\begin{array}{l}473.19 \\
477.91 \\
482.57 \\
487.17 \\
491.71\end{array}$ & $\begin{array}{l}4.747 \\
4.688 \\
4.629 \\
4.570 \\
4.511\end{array}$ & $\begin{array}{l}-58.8 \\
-59.0 \\
-59.2 \\
-59.4 \\
-59.5\end{array}$ & $\begin{array}{l}165 \\
166 \\
167 \\
168 \\
169\end{array}$ & $\begin{array}{l}651.92 \\
653.20 \\
654.42 \\
655.59 \\
656.72\end{array}$ & $\begin{array}{l}1.300 \\
1.249 \\
1.198 \\
1.148 \\
1.098\end{array}$ & $\begin{array}{l}-51.1 \\
-50.8 \\
-50.6 \\
-50.3 \\
-50.1\end{array}$ \\
\hline $\begin{array}{l}50 \\
51 \\
52 \\
53 \\
54\end{array}$ & $\begin{array}{l}147.79 \\
153.88 \\
160.03 \\
166.23 \\
172.48\end{array}$ & $\begin{array}{l}6.068 \\
6.125 \\
6.176 \\
6.223 \\
6.265\end{array}$ & $\begin{array}{l}59.0 \\
54.0 \\
49.1 \\
44.3 \\
39.5\end{array}$ & $\begin{array}{l}110 \\
111 \\
112 \\
113 \\
114\end{array}$ & $\begin{array}{l}496.19 \\
500.61 \\
504.97 \\
509.27 \\
513.51\end{array}$ & $\begin{array}{l}4.451 \\
4.391 \\
4.331 \\
4.272 \\
4.211\end{array}$ & $\begin{array}{l}-59.7 \\
-59.8 \\
-59.9 \\
-60.0 \\
-60.1\end{array}$ & $\begin{array}{l}170 \\
171 \\
172 \\
173 \\
174\end{array}$ & $\begin{array}{l}657.79 \\
658.81 \\
659.78 \\
660.71 \\
661.58\end{array}$ & $\begin{array}{l}1.048 \\
0.998 \\
0.948 \\
0.899 \\
0.850\end{array}$ & $\begin{array}{l}-49.9 \\
-49.6 \\
-49.4 \\
-49.2 \\
-49.0\end{array}$ \\
\hline $\begin{array}{l}55 \\
56 \\
57 \\
58 \\
59\end{array}$ & $\begin{array}{l}178.76 \\
185.08 \\
191.43 \\
197.80 \\
204.20\end{array}$ & $\begin{array}{l}6.302 \\
6.334 \\
6.363 \\
6.386 \\
6.406\end{array}$ & $\begin{array}{l}34.9 \\
30.3 \\
25.9 \\
21.5 \\
17.3\end{array}$ & $\begin{array}{l}115 \\
116 \\
117 \\
118 \\
119\end{array}$ & $\begin{array}{l}517.69 \\
521.82 \\
525.88 \\
529.88 \\
533.82\end{array}$ & $\begin{array}{l}4.151 \\
4.091 \\
4.031 \\
3.971 \\
3.911\end{array}$ & $\begin{array}{l}-60.1 \\
-60.2 \\
-60.2 \\
-60.2 \\
-60.3\end{array}$ & $\begin{array}{l}175 \\
176 \\
177 \\
178 \\
179\end{array}$ & $\begin{array}{l}662.41 \\
663.18 \\
663.91 \\
664.59 \\
665.22\end{array}$ & $\begin{array}{l}0.801 \\
0.752 \\
0.704 \\
0.656 \\
0.608\end{array}$ & $\begin{array}{l}-48.7 \\
-48.5 \\
-48.3 \\
-48.1 \\
-47.9\end{array}$ \\
\hline 60 & 210.61 & 6.421 & 13.2 & 120 & 537.70 & 3.850 & $-60 \cdot 3$ & 180 & 665.81 & 0.560 & -47.7 \\
\hline
\end{tabular}




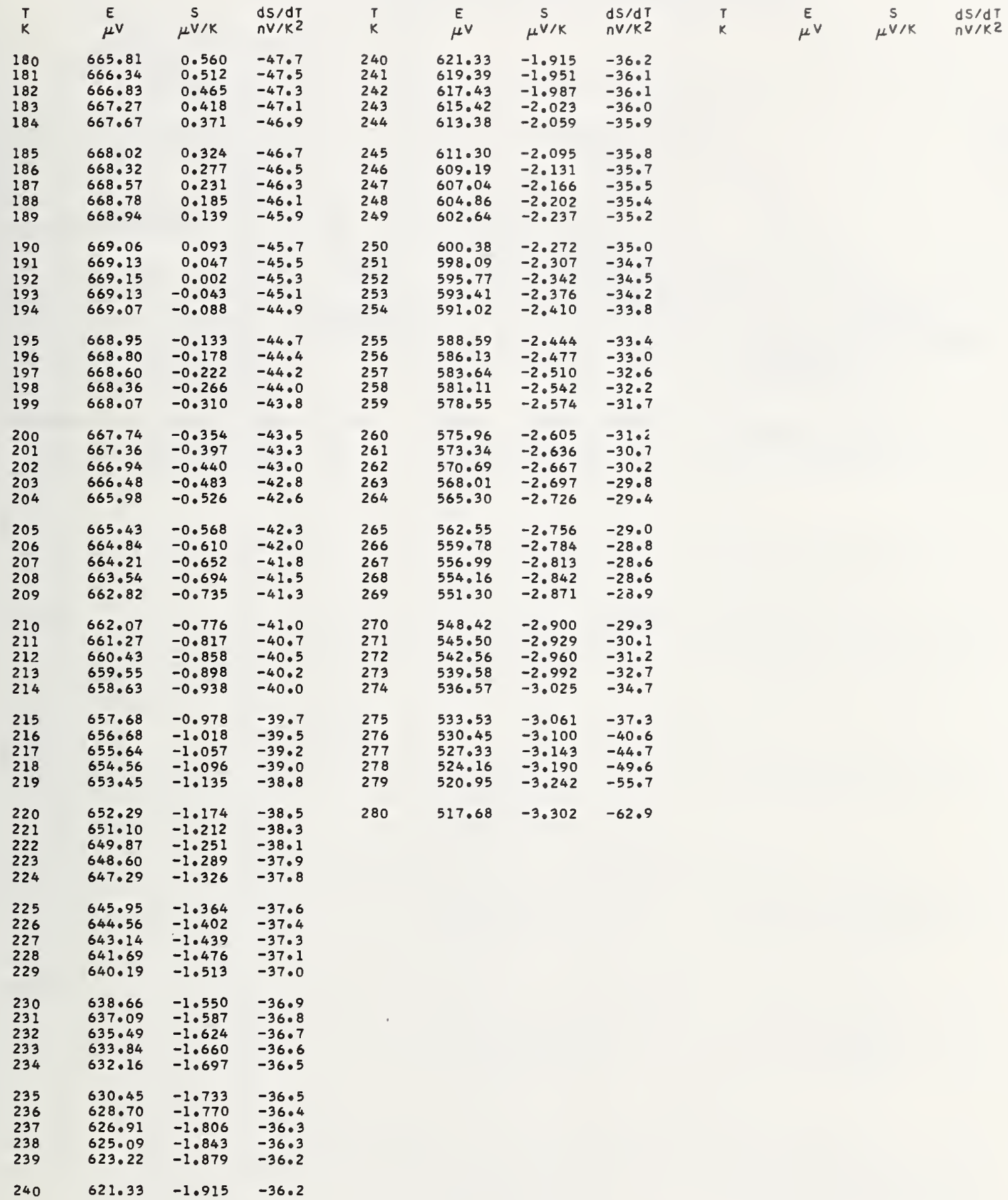




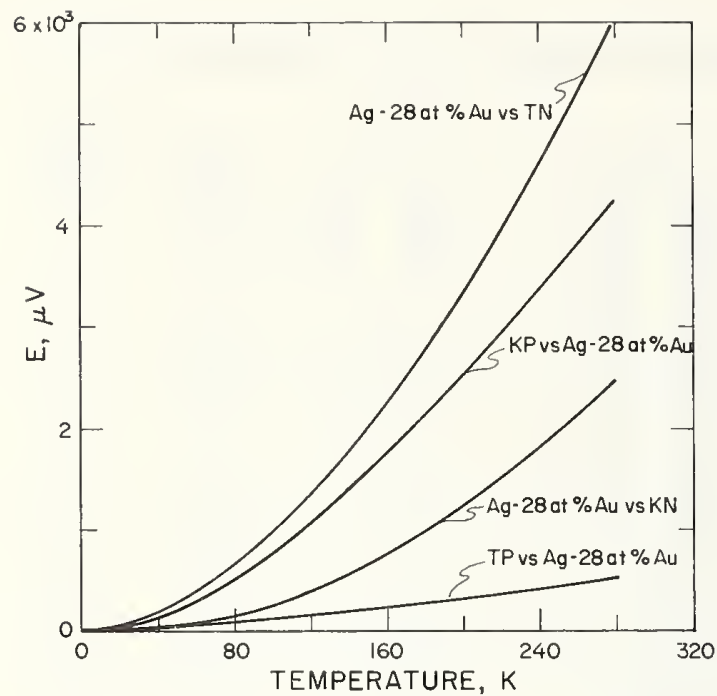

Figure 17. Thermoelectric voltage for thermocouple materials versus $\mathrm{Ag}$-28 at\% $\mathrm{Au}$.

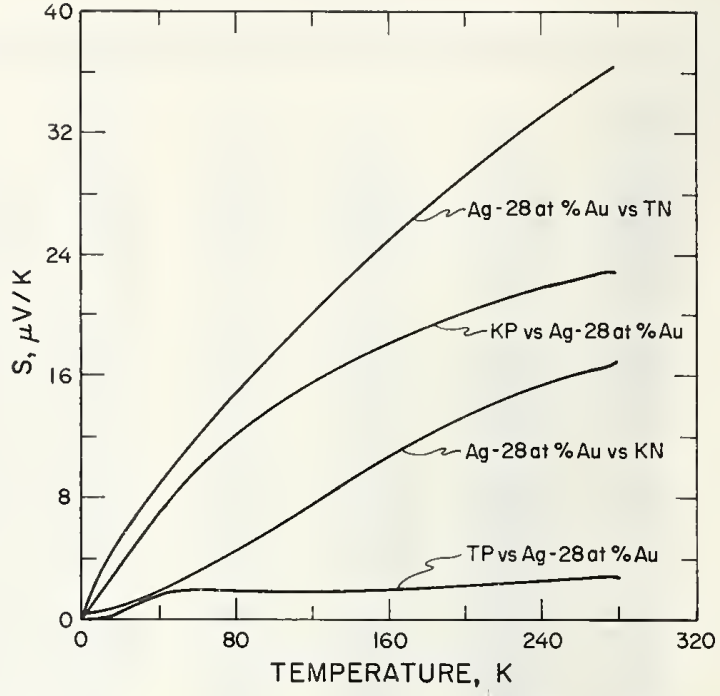

Figure 18. Seebech coefficient for thermocouple materials versus Ag-28 at $\%$ Au. 
$F(1)=2.62695799729 * 10^{-3} \mathrm{~T}$

$F(2)=\left[3.21644559388 * 10^{-5} \mathrm{~T}-1.11692313742 * 10^{-2}\right] \mathrm{T}$

$F(3)=\left[\left(3.58994672085 * 10^{-7} \mathrm{~T}-1.55668898366 * 10^{-4}\right) \mathrm{T}\right.$ $\left.+1.81141779139 * 10^{-2}\right] \mathrm{T}$

$F(4)=\left[\left(\left[5.34771916750 * 10^{-9} \mathrm{~T}-3.05001967653 * 10^{-6}\right] \mathrm{T}\right.\right.$ $\left.\left.+5.54667177985 * 10^{-4}\right) \mathrm{T}-3.34658422520 * 10^{-2}\right] \mathrm{T}$

$F(5)=\left[\left(\left[\left(6.07172355876 * 10^{-11} \mathrm{~T}-4.27432761250 * 10^{-8}\right) \mathrm{T}\right.\right.\right.$ $\left.\left.\left.+1.07134115475 * 10^{-5}\right] \mathrm{T}-1.13778202262 * 10^{-3}\right) \mathrm{T}+4.64639951890 * 10^{-2}\right] \mathrm{T}$

$F(6)=\left[\left(\left[\left(\left[8.82401710220 * 10^{-13} \mathrm{~T}-7.28215534531 * 10^{-10}\right] \mathrm{T}\right.\right.\right.\right.$ $\left.\left.\left.+2.24773793974 * 10^{-7}\right) \mathrm{T}-3.18955000427 * 10^{-5}\right] \mathrm{T}+2.05440454443 * 10^{-3}\right) \mathrm{T}$ $\left.-5.17932580803 * 10^{-2}\right] \mathrm{T}$

$F(7)=\left[\left(\left[\left(\left[\left(1.33824606626 * 10^{-14} \mathrm{~T}-1.32028601056 * 10^{-11}\right) \mathrm{T}\right.\right.\right.\right.\right.$ $\left.\left.\left.+5.13259305511 * 10^{-9}\right] \mathrm{T}-9.93311925650 * 10^{-7}\right) \mathrm{T}+9.91984763183 * 10^{-5}\right] \mathrm{T}$ $\left.\left.-4.75613476303 * 10^{-3}\right) \mathrm{T}+8.88013836676 * 10^{-2}\right] \mathrm{T}$

$F(8)=\left[\left(\left[\left(\left[\left(\left[1.91132074699 * 10^{-16} \mathrm{~T}-2.16764477633 * 10^{-13}\right] \mathrm{T}\right.\right.\right.\right.\right.\right.$ $\left.\left.\left.+1.00343183849 * 10^{-10}\right) \mathrm{T}-2.43627536044 * 10^{-8}\right] \mathrm{T}+3.31511839310 * 10^{-6}\right) \mathrm{T}$ $\left.\left.\left.-2.49812576663 * 10^{-4}\right] \mathrm{T}+9.57751308277 * 10^{-3}\right) \mathrm{T}-1.50632954813 * 10^{-1}\right] \mathrm{T}$

$F(9)=\left[\left(\left[\left(\left[\left(\left[\left(2.92699640234 * 10^{-18} \mathrm{~T}-3.70260683908 * 10^{-15}\right) \mathrm{T}\right.\right.\right.\right.\right.\right.\right.$

$\left.\left.\left.+1.95728888009 * 10^{-12}\right] \mathrm{T}-5.60626859326 * 10^{-10}\right) \mathrm{T}+9.43455906591 * 10^{-8}\right] \mathrm{T}$ $\left.\left.\left.-9.46059087662 * 10^{-6}\right) \mathrm{T}+5.47509430874 * 10^{-4}\right] \mathrm{T}-1.67843839799 * 10^{-2}\right) \mathrm{T}$ $\left.+2.24865631061 * 10^{-1}\right] \mathrm{T}$

$F(10)=\left[\left(\left[\left([)\left[\left(\left[3.95878009884 * 10^{-20} \mathrm{~T}-5.60672761438 * 10^{-17}\right] \mathrm{T}\right.\right.\right.\right.\right.\right.$

$\left.\left.\left.+3.38846529678 * 10^{-14}\right) \mathrm{T}-1.14017603261 * 10^{-11}\right] \mathrm{T}+2.33739535638 * 10^{-9}\right) \mathrm{T}$ $\left.\left.\left.-3.00235955099 * 10^{-7}\right] \mathrm{T}+2.39472835021 * 10^{-5}\right) \mathrm{T}-1.13608914666 * 10^{-3}\right] \mathrm{T}$ $\left.\left.+2.93503055072 * 10^{-2}\right) \mathrm{T}-3.46577248522 * 10^{-1}\right] \mathrm{T}$

$F(1])=\left[\left(\left[\left(\left[\left(\left[\left(\left[\left(5.38594950415 * 10^{-22} \mathrm{~T}-8.32449251443 * 10^{-19}\right) \mathrm{T}\right.\right.\right.\right.\right.\right.\right.\right.\right.$ $\left.\left.\left.+5.56752245363 * 10^{-16}\right] \mathrm{T}-2.11081095546 * 10^{-13}\right) \mathrm{T}+4.99305085248 * 10^{-11}\right] \mathrm{T}$ $\left.\left.\left.-7.64533953636 * 10^{-9}\right) \mathrm{T}+7.61388315316 * 10^{-7}\right] \mathrm{T}-4.83235619795 * 10^{-5}\right) \mathrm{T}$ $\left.\left.\left.+1.86364817796 * 10^{-3}\right] \mathrm{T}-4.00502423767 * 10^{-2}\right) \mathrm{T}+4.09600033130 * 10^{-1}\right] \mathrm{T}$

$F(12)=\left[\left(\left[\left([)\left[\left(\left[\left(\left[8.26258016537 * 10^{-24} \mathrm{~T}-1.39945594083 * 10^{-20}\right] \mathrm{T}\right.\right.\right.\right.\right.\right.\right.\right.$

$\left.\left.\left.+1.03888019552 * 10^{-17}\right) \mathrm{T}-4.44103690669 * 10^{-15}\right] \mathrm{T}+1.20799873313 * 10^{-12}\right) \mathrm{T}$ $\left.\left.\left.-2.18091879863 * 10^{-10}\right] \mathrm{T}+2.64614938335 * 10^{-8}\right) \mathrm{T}-2.13892665858 * 10^{-6}\right] \mathrm{T}$ $\left.\left.\left.+1.11908345512 * 10^{-4}\right) \mathrm{T}-3.59445386267 * 10^{-3}\right] \mathrm{T}+6.49375809159 * 10^{-2}\right) \mathrm{T}$ - $\left.5.70520840814 * 10^{-1}\right] \mathrm{T}$

$F(13)=\left[\left(\left[\left(\left[\left(\left[\left(\left[\left(\left[(1.2546871799) * 10^{-25} \mathrm{~T}-2.30116953479 * 10^{-22}\right) \mathrm{T}\right.\right.\right.\right.\right.\right.\right.\right.\right.\right.$ $\left.\left.\left.+1.87050454270 * 10^{-19}\right] \mathrm{T}-8.87619885518 * 10^{-17}\right) \mathrm{T}+2.72633781444 * 10^{-14}\right] \mathrm{T}$ $\left.\left.\left.-5.67992988009 * 10^{-12}\right) \mathrm{T}+8.17885879975 * 10^{-10}\right] \mathrm{T}-8.14236157658 * 10^{-8}\right) \mathrm{T}$ $\left.\left.\left.+5.51694463147 * 10^{-6}\right] \mathrm{T}-2.46137502017 * 10^{-4}\right) \mathrm{T}+6.83930829183 * 10^{-3}\right] \mathrm{T}$ - $\left.\left.1.08276043179 * 10^{-1}\right) \mathrm{T}+8.45979503380 * 10^{-1}\right] \mathrm{T}$

$F(14)=\left[\left(\left[\left(\left[\left([)\left[\left(\left[\left(\left[1.85361805469 * 10^{-27} \mathrm{~T}-3.66118430728 * 10^{-24}\right] \mathrm{T}\right.\right.\right.\right.\right.\right.\right.\right.\right.\right.$ $\left.\left.\left.+3.23511219579 * 10^{-21}\right) \mathrm{T}-1.68774968707 * 10^{-18}\right] \mathrm{T}+5.77794561728 * 10^{-16}\right) \mathrm{T}$ $\left.\left.\left.-1.36468119697 * 10^{-13}\right] \mathrm{T}+2.27608365626 * 10^{-11}\right) \mathrm{T}-2.69817191322 * 10^{-9}\right] \mathrm{T}$ $\left.\left.\left.+2.25821878327 * 10^{-7}\right) \mathrm{T}-1.30846653820 * 10^{-5}\right] \mathrm{T}+5.06904044529 * 10^{-4}\right) \mathrm{T}$ $\left.\left.\left.-1.24174854893 * 10^{-2}\right] \mathrm{T}+1.76141425155 * 10^{-1}\right) \mathrm{T}-1.25341332333\right] \mathrm{T}$ 
TABLE 31. Orthonormal polynomial coefficients for thermocouple types $T, E, K, \mathrm{Pt}$ versus TP, $K P($ or EP) versus $\mathrm{Pt}$, and $\mathrm{Pt}$ versus $K N ; \mathrm{E}=\mathrm{f}(\mathrm{T})$

\begin{tabular}{|c|c|c|c|c|c|c|}
\hline \multirow{2}{*}{$\begin{array}{l}\text { Orthogonal } \\
\text { polynomial } \\
\text { coefficients }\end{array}$} & \multicolumn{6}{|c|}{ Thermocouple Type } \\
\hline & $\mathrm{T}$ & $\mathrm{E}$ & $\mathrm{K}$ & $P t$ versus $T P$ & $K P$ versus $P t$ & Pt versus KN \\
\hline $\begin{array}{l}A(1) \\
A(2) \\
A(3) \\
A(4) \\
A(5) \\
A(6) \\
A(7) \\
A(8) \\
A(9) \\
A(10) \\
A(12) \\
A(13) \\
A(14)\end{array}$ & $\begin{array}{r}0.0 \\
10,673.449 \\
1,947.339 \\
-1.58 .363 \\
44.549 \\
-34.604 \\
11.028 \\
-0.281 \\
-2.977 \\
2.087 \\
-1.098 \\
-0.055 \\
.558 \\
-.641 \\
.430\end{array}$ & $\begin{array}{r}0.0 \\
16,803.073 \\
2,969.618 \\
-404.812 \\
65.116 \\
-22.801 \\
3.257 \\
1.746 \\
-1.931 \\
0.340 \\
.107 \\
-.720 \\
. .581 \\
-.348\end{array}$ & $\begin{array}{r}0.0 \\
11,244.719 \\
2,174.984 \\
-297.765 \\
5.348 \\
-4.536 \\
-0.486 \\
2.117 \\
-1.922 \\
0.780 \\
-0.288\end{array}$ & $\begin{array}{r}1.39 \\
-442.405 \\
-695.540 \\
-123.572 \\
107.723 \\
-45.512 \\
3.506 \\
5.395 \\
-4.032 \\
0.601 \\
1.034 \\
-1.055 \\
0.635\end{array}$ & $\begin{array}{r}0.79 \\
6572.181 \\
1717.903 \\
-122.875 \\
-87.182 \\
57.285 \\
-11.373 \\
-3.425 \\
5.110 \\
-2.236 \\
0.262 \\
.445 \\
-.609\end{array}$ & $\begin{array}{r}-0.22 \\
4672.551 \\
457.074 \\
-174.884 \\
92.560 \\
-61.819 \\
10.886 \\
5.557 \\
-7.052 \\
3.026 \\
-0.555 \\
-.587 \\
.822\end{array}$ \\
\hline
\end{tabular}

TABLE 32. Orthonormal polynomial coefficients for thermocouple types $\mathrm{Pt}$ versus TN (or EN), KP (or EP) versus Ag.28 at \% Au, Ag.28 at\% Au versus KN, TP versus Ag-28 at\% Au, Ag-28 at\% Au versus TN (or EN), and $\overline{\mathrm{Pt}}$ versus Ag-28 at\% Au; $\mathrm{E}=\mathrm{f}(\mathrm{T})$

\begin{tabular}{|c|c|c|c|c|c|c|}
\hline \multirow{2}{*}{$\begin{array}{l}\text { Orthogonal } \\
\text { polynomial } \\
\text { coefficients }\end{array}$} & \multicolumn{6}{|c|}{ Thermocouple Type } \\
\hline & $\mathrm{Pt}$ versus $\mathrm{TN}$ & $\begin{array}{c}\mathrm{KP} \text { versus } \\
\mathrm{Ag}-28 \mathrm{Au}\end{array}$ & $\begin{array}{l}\frac{\mathrm{Ag}-28 \mathrm{Au}}{\text { versus } \mathrm{KN}}\end{array}$ & $\begin{array}{l}\text { TP versus } \\
\mathrm{Ag}-28 \mathrm{Au}\end{array}$ & $\frac{\mathrm{Ag}-28 \mathrm{Au}}{\text { versus TN }}$ & $\begin{array}{l}\text { Pt versus } \\
\text { Ag. } 28 \mathrm{Au}\end{array}$ \\
\hline $\begin{array}{l}A_{0}, \\
A(1) \\
A(2) \\
A(3) \\
A(5) \\
A(6) \\
A(7) \\
A(8) \\
A(9) \\
A(10) \\
A(11) \\
A(12) \\
A(13) \\
A(14)\end{array}$ & $\begin{array}{r}0.0 \\
10,230.996 \\
1,251.750 \\
-281.919 \\
152.320 \\
-80.096 \\
14.588 \\
5.157 \\
-7.032 \\
2.637 \\
-0.111 \\
-1.147 \\
1.178 \\
-0.681\end{array}$ & $\begin{array}{r}0.79 \\
6,956.840 \\
1,107.199 \\
-246.253 \\
47.181 \\
-12.833 \\
-0.096 \\
2.649 \\
-2.283 \\
1.069 \\
-0.365 \\
-.216 \\
.111 \\
-.511\end{array}$ & $\begin{array}{r}-0.22 \\
4,287.892 \\
1,067.778 \\
-51.506 \\
-41.803 \\
8.299 \\
-0.391 \\
-.517 \\
.342 \\
-.279 \\
.072 \\
.074 \\
.102 \\
.511\end{array}$ & $\begin{array}{r}-1.39 \\
827.064 \\
84.835 \\
0.194 \\
26.640 \\
-24.606 \\
7.771 \\
0.679 \\
-3.361 \\
2.704 \\
-1.661 \\
0.394 \\
.085 \\
-.511\end{array}$ & $\begin{array}{r}0.0 \\
9,846.336 \\
1,862.454 \\
-158.541 \\
17.957 \\
-9.978 \\
3.310 \\
-0.917 \\
.361 \\
-.668 \\
. .516 \\
-.486 \\
.458 \\
-.170\end{array}$ & $\begin{array}{r}0.0 \\
384.659 \\
-610.705 \\
-123.378 \\
134.363 \\
-70.118 \\
11.277 \\
6.074 \\
-7.393 \\
3.305 \\
-0.627 \\
-.661 \\
.720 \\
-.511\end{array}$ \\
\hline
\end{tabular}


TABLE 33. Standard deviations $(\mu V)$ of reduced order fits for thermocouple types $T, E, K$, $\mathrm{Pt}$ versus TP, KP (or EP) versus $\mathrm{Pt}$, and $\mathrm{Pt}$ versus $K N ; \mathrm{E}=\mathrm{f}(\mathrm{T})$

\begin{tabular}{|c|c|c|c|c|c|c|}
\hline \multirow{2}{*}{$\begin{array}{l}\text { Number } \\
\text { of } \\
\text { coefficients }\end{array}$} & \multicolumn{6}{|c|}{ Approximate Standard Deviation } \\
\hline & $\mathrm{T}$ & $\mathbf{E}$ & $\mathrm{K}$ & Pt versus TP & $K \mathrm{P}$ versus $\mathrm{Pt}$ & Pt versus KN \\
\hline $\begin{array}{r}4 \\
5 \\
6 \\
7 \\
8 \\
8 \\
9 \\
10 \\
11 \\
12 \\
13 \\
14\end{array}$ & $\begin{array}{l}5 \\
1.6 \\
0.7 \\
.6 \\
.4 \\
.3 \\
.2 \\
.15 \\
.13 \\
.09 \\
.07\end{array}$ & $\begin{array}{l}3 \\
0.6 \\
.5 \\
.4 \\
.2 \\
.19 \\
.18 \\
.15 \\
.13 \\
.12\end{array}$ & $\begin{array}{l}1 \\
0.5 \\
.4 \\
.3 \\
.13 \\
.09 \\
.08\end{array}$ & $\begin{array}{l}6 \\
1.1 \\
1.0 \\
0.6 \\
.3 \\
.2 \\
.19 \\
.13 \\
.10\end{array}$ & $\begin{array}{l}8 \\
1.7 \\
0.9 \\
.8 \\
.4 \\
.16 \\
.15 \\
.13 \\
.11\end{array}$ & $\begin{array}{l}9 \\
2 \\
1.2 \\
1.0 \\
0.4 \\
.18 \\
.17 \\
.15 \\
.10\end{array}$ \\
\hline
\end{tabular}

TABLE 34. Standard deviations $(\mu V)$ of reduced order fits for thermocouple types $\mathrm{Pt}$ versus TN (or EN), KP (or EP) versus $\mathrm{Ag}-28$ at $\% \mathrm{Au}, \mathrm{Ag}-28$ at $\% \mathrm{Au}$ versus $\mathrm{KN}, \mathrm{TP}$ versus Ag-28 at\% Au, Ag-28 at\% Au versus TN (or EN), and $\mathrm{Pt}$ versus Ag-28 at\% Au; $\mathrm{E}=\mathrm{f}(\mathrm{T})$

\begin{tabular}{|c|c|c|c|c|c|c|}
\hline \multirow{2}{*}{$\begin{array}{l}\text { Number } \\
\text { of } \\
\text { coefficients }\end{array}$} & \multicolumn{6}{|c|}{ Approximate Standard Deviation } \\
\hline & Pt versus TN & $\begin{array}{l}\mathrm{KP} \text { versus } \\
\mathrm{Ag}-28 \mathrm{Au}\end{array}$ & $\frac{\mathrm{Ag}-28 \mathrm{Au}}{\text { versus } \mathrm{KN}}$ & $\begin{array}{l}\text { TP versus } \\
\underline{\mathrm{Ag}} \cdot 28 \mathrm{Au}\end{array}$ & $\frac{\mathrm{Ag}-28 \mathrm{Au}}{\text { versus } \mathrm{TN}}$ & $\begin{array}{l}\mathrm{Pt} \text { versus } \\
\mathrm{Ag} .28 \mathrm{Au}\end{array}$ \\
\hline $\begin{array}{r}4 \\
5 \\
5 \\
6 \\
7 \\
8 \\
9 \\
9 \\
10 \\
11 \\
12 \\
13 \\
14 \\
15 \\
16\end{array}$ & $\begin{array}{l}11 \\
3 \\
1.3 \\
1.1 \\
0.6 \\
0.5 \\
0.4 \\
0.3 \\
0.15 \\
0.12\end{array}$ & $\begin{array}{c}13 \\
3 \\
1.7 \\
1.4 \\
0.7 \\
0.4 \\
0.3 \\
0.2 \\
0.15 \\
0.08 \\
0.07 \\
0.06 \\
0.05\end{array}$ & $\begin{array}{c}14 \\
3 \\
1.9 \\
1.5 \\
0.7 \\
0.5 \\
0.4 \\
0.3 \\
0.14 \\
0.08 \\
0.07 \\
0.06 \\
0.05\end{array}$ & $\begin{array}{c}12 \\
3 \\
1.8 \\
1.3 \\
0.6 \\
0.4 \\
0.3 \\
0.2 \\
0.14 \\
0.08 \\
0.07 \\
0.06 \\
0.05\end{array}$ & $\begin{array}{l}15 \\
4 \\
2 \\
1.6 \\
0.8 \\
0.6 \\
0.5 \\
0.4 \\
0.18 \\
0.15 \\
0.07 \\
0.06 \\
0.05\end{array}$ & $\begin{array}{l}10 \\
2 \\
1.4 \\
1.1 \\
0.5 \\
0.18 \\
0.16 \\
0.14 \\
0.09 \\
0.08 \\
0.07 \\
0.06 \\
0.05\end{array}$ \\
\hline
\end{tabular}

TABLE 35. Number of digits necessary in computations to reduce round-off errors below certain limits for thermocouple types $E, K$, and $T$

\begin{tabular}{|c|c|c|c|c|c|c|}
\hline \multirow{2}{*}{$\begin{array}{l}\text { Error criteria } \\
\text { (microvolts) }\end{array}$} & \multicolumn{6}{|c|}{ Number of digits necessary for thermocouple } \\
\hline & \multicolumn{2}{|c|}{ Type E } & \multicolumn{2}{|c|}{ Type K } & \multicolumn{2}{|c|}{ Type T } \\
\hline $\begin{array}{c}0.01 \\
0.1 \\
1 . \\
50\end{array}$ & $\begin{array}{c}\text { binary } \\
33 \\
29 \\
24\end{array}$ & $\begin{array}{c}\text { decimal } \\
10 \\
9 \\
8\end{array}$ & $\begin{array}{c}\text { binary } \\
26 \\
24 \\
24\end{array}$ & $\begin{array}{c}\text { decimal } \\
8 \\
8 \\
8 \\
\end{array}$ & $\begin{array}{c}\text { binary } \\
38 \\
35 \\
32 \\
24\end{array}$ & $\begin{array}{c}\text { decimal } \\
12 \\
11 \\
10 \\
8\end{array}$ \\
\hline
\end{tabular}




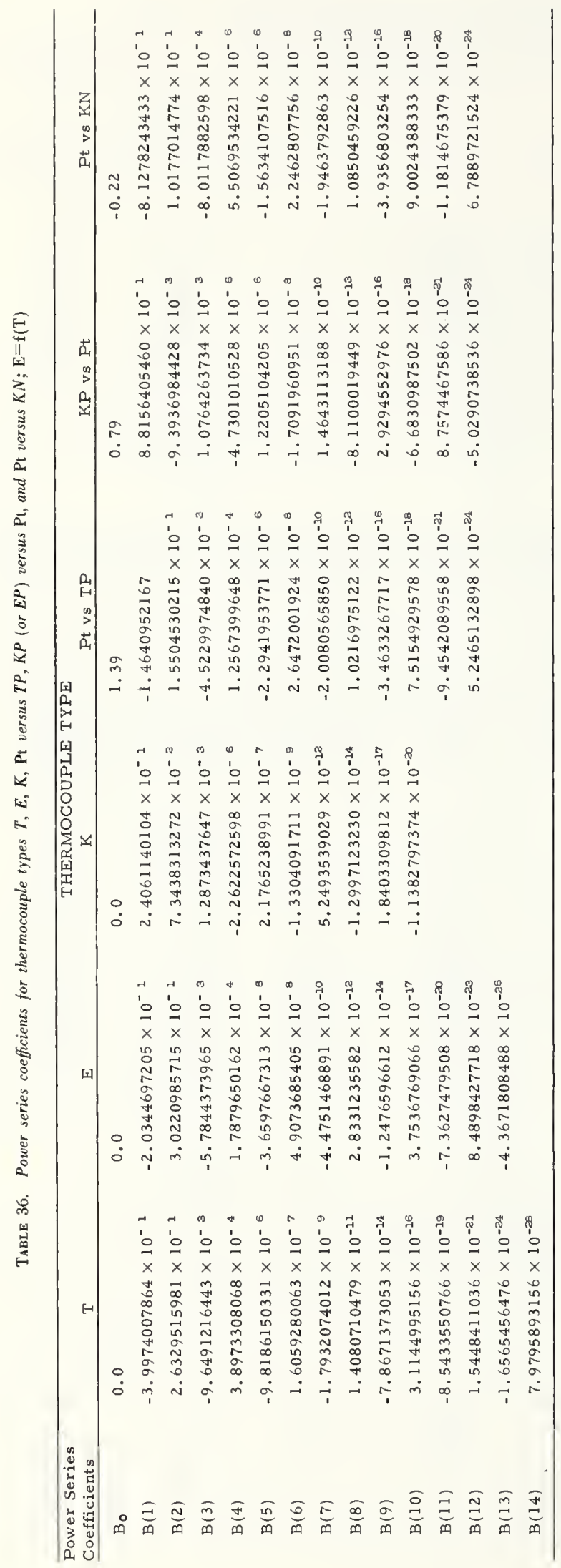

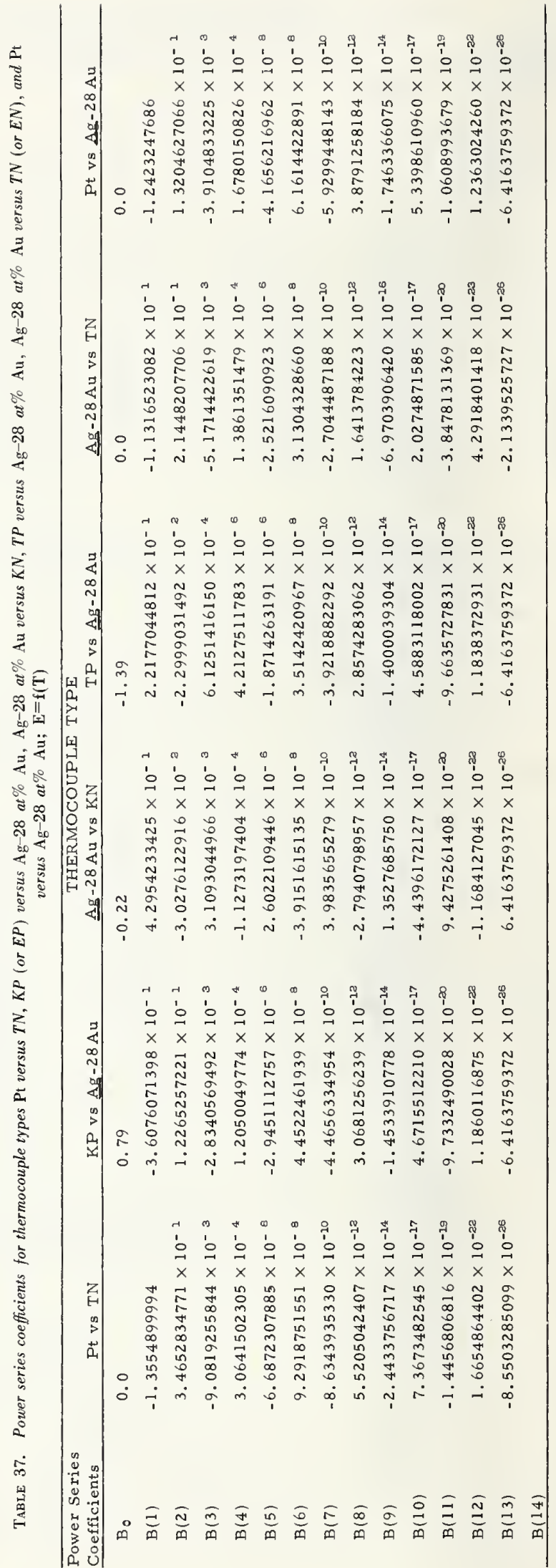




\section{References}

[1] MacDonald, D. K. C., Thermoelectricity: An Introduction to the Principles, pp. 103-116 (John Wiley and Sons, Inc., New York, London, 1962).

[2] Shenker, H., Lauritzen, J. I., Jr., Corruccini, R. J., and Lonberger, S. T., Reference tables for thermocouples, Nat. Bur. Stand. (U.S.), Circ. 561, 84 pages (1955).

[3] Brombacher, W. G., Johnson, D. P., Cross, J. L., Mercury Barometers and Manometers, Nat. Bur. Stand. (U.S.), Monogr. 8, 59 pages (May 1960).

[4] Brickwedde, F. G., van Dijk, H., Durieux, M., Clement, J. R., Logan, J. K., The $1958 \mathrm{He}^{4}$ Scale of Temperatures, Nat. Bur. Stand. (U.S.), Monogr. 10, 17 pages (June 1960).

[5] Sparks, L. L., and Powell, R. L., Calibration of Capsule Platinum Resistance Thermometers at the Triple Point of Water, Fifth Symposium on Temperature, Washington, D.C., June 21-24, 1971. To be published in Temperature-Its Measurement and Control in Science and Industry 4, Ed. H. H. Plumb, (Instrument Society of America, Pittsburgh, Pennsylvania, 1972).

[6] Stimson, H. F., Precision Resistance Thermometry and Fixed Points, Third Symposium on Temperature, Wash. ington, D.C., October 28-30, 1954, Temperature-Its Measurement and Control in Science and Industry 2, Ed. H. C. Wolfe, (Reinhold Publishing Corp., New York, 1955).

[7] Berry, R. J., The Temperature Time Dependence of the Triple Point of Water, Can. J. Phys. 37, 1230-1248 (1959).

[8] Riddle, J. L., Notes to Supplement Resistance Thermometer Reports, Precision Measurement and Calibration. Selected NBS Papers on Temperature, Ed. J. F. Swindells, Nat. Bur. Stand. (U.S.), Spec. Publ. 300, Vol. 2, 150-1 (Aug. 1968).

[9] Hust, J. G:, Thermal Anchoring of Wires in Cryogenic Apparatus, Rev. Sci. Instr. 41, 622-624 (1970).

[10] Brooks, P. P. B., Calibration of Mueller Thermometer Bridge, Nat. Bur. Stand. (U.S.), Internal Report, 29 pages (1965).

[11] Tuttle, W. F., Connectivity in Graphs, (University of Toronto Press 1966).

[12] Youden, W. J., Measurement Agreement Comparisons, Paper 5.1, Nat. Bur. Stand. (U.S.), Misc. Publ. 248, 254 pages (1963).

[13] Essam, J. W., and Fisher, M. E., Some Basic Definitions in Graph Theory, Rev. Mod. Phys. 42, No. 2, 271-288 (ApriI 1970).

[14] Hust, J. G., A compilation and Historical Review of Temperature Scale Differences, Cryogenics 9, No. 6, 443-455 (December 1969).
[15] Björck, A., Solving Linear Least Squares Problems by Gram-Schmidt Orthogonalization, Bit, Nordisk Tidsprift for Informationsbehandling 7, 1-21 (1967).

[16] Powell, R. L., Hall, W. J., and Hust, J. G., The Fitting of Resistance Thermometer Data by Orthogonal Functions, Fifth Symposium on Temperature, Washington, D.C. June 21-24, 1971. To be published in Temperature-Its Measurement and Control in Science and Industry 4, Ed. H. H. Plumb, (Instrument Society of America, Pittsburgh, Pennsylvania, 1972).

[17] Finch, D. I., General Principles of Thermoelectric Ther. mometry, Fourth Symposium on Temperature, Columbus, Ohio, March 27-31, 1961, Temperature-Its Measurement and Control in Science and Industry 3, Ed. A. I. Dahl, (Reinhold Publishing Corp., New York, 1962.

[18] Wilson, E. B., An Introduction to Scientific Research, 272-274 (McGraw-Hill Book Company, Inc., New York, 1952).

[19] Ku, H. H., Notes on the Use of Propagation of Error Formulas, J. Res. Nat. Bur. Stand. (U.S.), 70C (Eng. and Instr.), No. 4, 263-273 (Oct.-Dec. 1966).

[20] Reference Base of the Volt to be Changed, Nat. Bur. Stand. (U.S.), Tech. News Bull. 52, 204-206 (Sept. 1968).

[21] International Practical Temperature Scale of 1968 , Adopted by the Comite International des Poids et Messures, Metrologia 5, No. 2, 35-44 (April 1969).

[22] Bedford, R. E., Durieuz, M., Muijlwijk, R., and Barber, C. R., Relationships Between the International Practical Temperature Scale of 1968 and the NBS-55, NPL-61, PRMI-54, and PSU-54 Temperature Scales in the Range from 13.81 to $90.188 \mathrm{~K}$, Metrologia 5, No. 2, 47-49 (April 1969).

[23] Bedford, R. E., and Kirby, C. G. M., Notes on the Application of the International Practical Temperature Scale of 1968, Metrologia 5, No. 3, 83-87 (July 1969).

[24] Rogers, J. S., Tainish, R. J., Anderson, M. S., and Swenson, C. A., Comparison Between Gas Thermometer, Acoustic, and Platinum Resistance Temperature Scales Between 2 and $20 \mathrm{~K}$, Metrologia 4, No. 2, 47-58 (April 1969).

[25] Plumb, H. H., and Cataland, G., Acoustical Thermometer and the National Bureau of Standards Provisional Temperature Scale 2-20 (1965), Metrologia 2, No. 4, 127-139 (1966)

[26] NBS (U.S.), Internal Reports (1968-1969).

[27] Manual on the Use of Thermocouples in Temperature Measurement, Ed. R. P. Benedict, ASTM Special Technical Publication 470 (1970).

\section{Appendix A. Standard designations for thernocouples}

ANSI, ASTM, and ISA (American National Standards Institute, American Society for Testing and Materials, and Instrument Society of America, respectively) have adopted the following letter designations for thermocouples described in this monograph:

\section{THERMOCOUPLE COMBINATIONS:}

The positive thermoelectric material is conventionally written first.

Type E Nickel-chromium alloy versus copper$\overline{\text { nickel }}$ alloy.
Type K

Type T

Nickel-chromium alloy versus nickelaluminum alloy.

Copper versus copper-nickel alloy.

\section{SINGLE-LEG WIRES:}

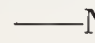

$-\mathrm{N}$

The negative wire in a combination.

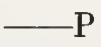

The positive wire in a combination.

EN or TN

A copper-nickel alloy, often referred to as Adams' constantan; Advancer, Cupron $^{4}$, nominally 55 wt $\% \mathrm{Cu}, 45 \% \mathrm{Ni}$. 
EP or KP A nickel-chromium alloy, often referred to as Chromel ${ }^{2} ; T-1^{1}$, ThermoKanthal $K P^{3}$, Tophel ${ }^{4}$; nominally $90 \% \mathrm{Ni}, 10 \%$ Cr.

$\mathrm{KN}$

A nickel-aluminum alloy, often referred to as Alumel ${ }^{2} ; T-2^{1}$, ThermoKanthal $K N^{3}, \mathrm{Nial}^{4}$; nominally $95 \% \mathrm{Ni}, 2 \% \mathrm{Al}$, $2 \% \mathrm{Mn}, 1 \% \mathrm{Si}$.

TP
Copper, usually Electrolytic Tough Pitch.
Registered Trademarks:

1 Trademark-Driver-Harris Co.

Trademark-Hoskins Manufacturing Co.

Trademark-Kanthal Corp.

4 Trademark-Wilbur B. Driver Co.

The use of trade names does not constitute an endorsement of any manufacturer's products. All materials manufactured in compliance with the established thermoelectric voltage standards are equally acceptable. 
FORM NBS-114A $\{1.71\}$

\begin{tabular}{|c|c|c|c|}
\hline $\begin{array}{l}\text { U.S. DEPT. OF COMM. } \\
\text { BIBLIOGRAPHIC DATA } \\
\text { SHEET }\end{array}$ & $\begin{array}{l}\text { 1. PUBLICATION OR REPORT NO. } \\
\text { NBS MN }-124\end{array}$ & $\begin{array}{l}\text { 2. Gov't Accession } \\
\text { No. }\end{array}$ & 3. Recipient's Accession No. \\
\hline \multirow{2}{*}{\multicolumn{3}{|c|}{$\begin{array}{l}\text { 4. TITLE AND SUBTITLE } \\
\text { Reference Tables for Low-Temperature Thermocouples }\end{array}$}} & $\begin{array}{c}\text { 5. Publication Date } \\
\text { June } 1972\end{array}$ \\
\hline & & & 6. Performing Organization Code \\
\hline $\begin{array}{l}\text { 7. AUTHOR(s) } \\
\text { Larry L. Sparks, }\end{array}$ & obert L. Powell, and Wi & $\mathrm{m} \mathrm{J} \cdot \mathrm{Hall}$ & 8. Performing Organization \\
\hline \multicolumn{3}{|c|}{$\begin{array}{l}\text { 9. PERF ORMING ORGANIZATION NAME AND ADDRESS } \\
\qquad \begin{array}{l}\text { NATIONAL BUREAU OF STANDARDS, Boulder Labs } \\
\text { DEPARTMENT OF COMMERCE } \\
\text { Boulder, Colorado } 80302\end{array}\end{array}$} & $\begin{array}{l}\text { 11. Contract/Grant No. } \\
R-45\end{array}$ \\
\hline \multirow{2}{*}{\multicolumn{3}{|c|}{$\begin{array}{l}\text { 12. Sponsoring Organization Name and Address } \\
\text { Space Nuclear Propulsion Office, Cleveland Extension } \\
\text { NASA Lewis Research Center } \\
21000 \text { Brook Park Road } \\
\text { Cleveland, Ohio } 44135\end{array}$}} & $\begin{array}{l}\text { 13. Type of Report \& Period } \\
\text { Covered } \\
\text { Final }\end{array}$ \\
\hline & & & 14. Sponsoring Agency Code \\
\hline
\end{tabular}

15. SUPPLEMENTARY NOTES

16. ABSTRACT (A 200-word or less factual summary of most significant information. If document includes a significant bibliography or literature survey, mention it here.)

The experimental program to establish low-temperature reference tables for the commonly used thermocouples has been completed. Details of the experimental system, instrumentation, data analysis, error analysis, and materials tested are given in order to allow the user to better evaluate and apply the results. The results presented here include:

(1) Reference tables for thermocouple types $E, K$, and $T$, both as $E=f(T)$ and $\mathrm{T}=f(\mathrm{E})$. The shorter $f(\mathrm{E})$ tables have a $0^{\circ} \mathrm{C}(273.15 \mathrm{~K})$ reference temperature while all other tables have a $0 \mathrm{~K}$ reference temperature.

(2) Reference tables for Pt and Ag - 28 at \% Au vs the materials used in thermocouple types $\mathrm{E}, \mathrm{K}$, and $\mathrm{T}$. These data are presented as $\mathrm{E}=f(\mathrm{~T})$ only.

(3) Orthogonal polynomials and the associated coefficients necessary to generate the data with reduced order approximations.

(4) Power series coefficients for full precision reproduction of the reference data.

The data presented in the $E=f(T)$ tables cover the temperature range from 0 to $280 \mathrm{~K}$. The $\mathrm{T}=f(\mathrm{E})$ tables cover the temperature ranges from $273.15 \mathrm{~K}$ down to the lowest temperatures allowed by table resolution.

17. KEY WORDS (AIphabetical order, separated by semicolons)

Cryogenics; homogeneity tests; liquid helium; liquid hydrogen; liquid nitrogen; thermocouples.

18. AVAILABILITY STATEMENT
\begin{tabular}{|l|l|l|}
\hline $\mathbf{x}$ UNLIMITED. & $\begin{array}{l}\text { 19. SECURITY CLASS NO. OF PAGES } \\
\text { (THIS REPORT) }\end{array}$ \\
\begin{tabular}{|l} 
FOR OFFICI AL DISTRIBUTION. DO NOT RELEASE \\
TO NTIS.
\end{tabular} & $\begin{array}{l}\text { 20. SECURITY CLASS } \\
\text { (THIS PAGE) } \\
\text { UNCLASSIFIED }\end{array}$ & $\begin{array}{l}\text { 22. Price } \\
60 \text { cents }\end{array}$ \\
\hline
\end{tabular}




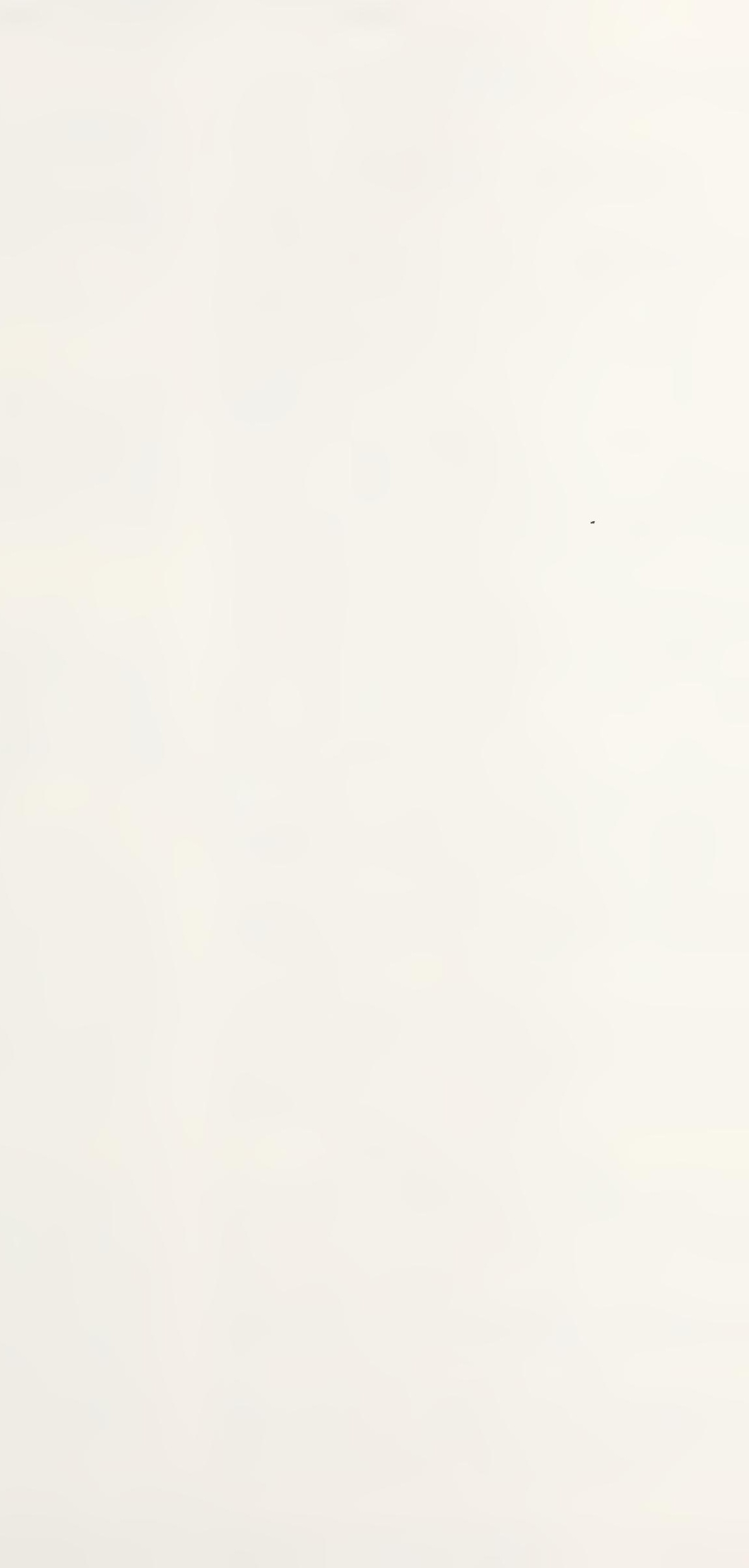

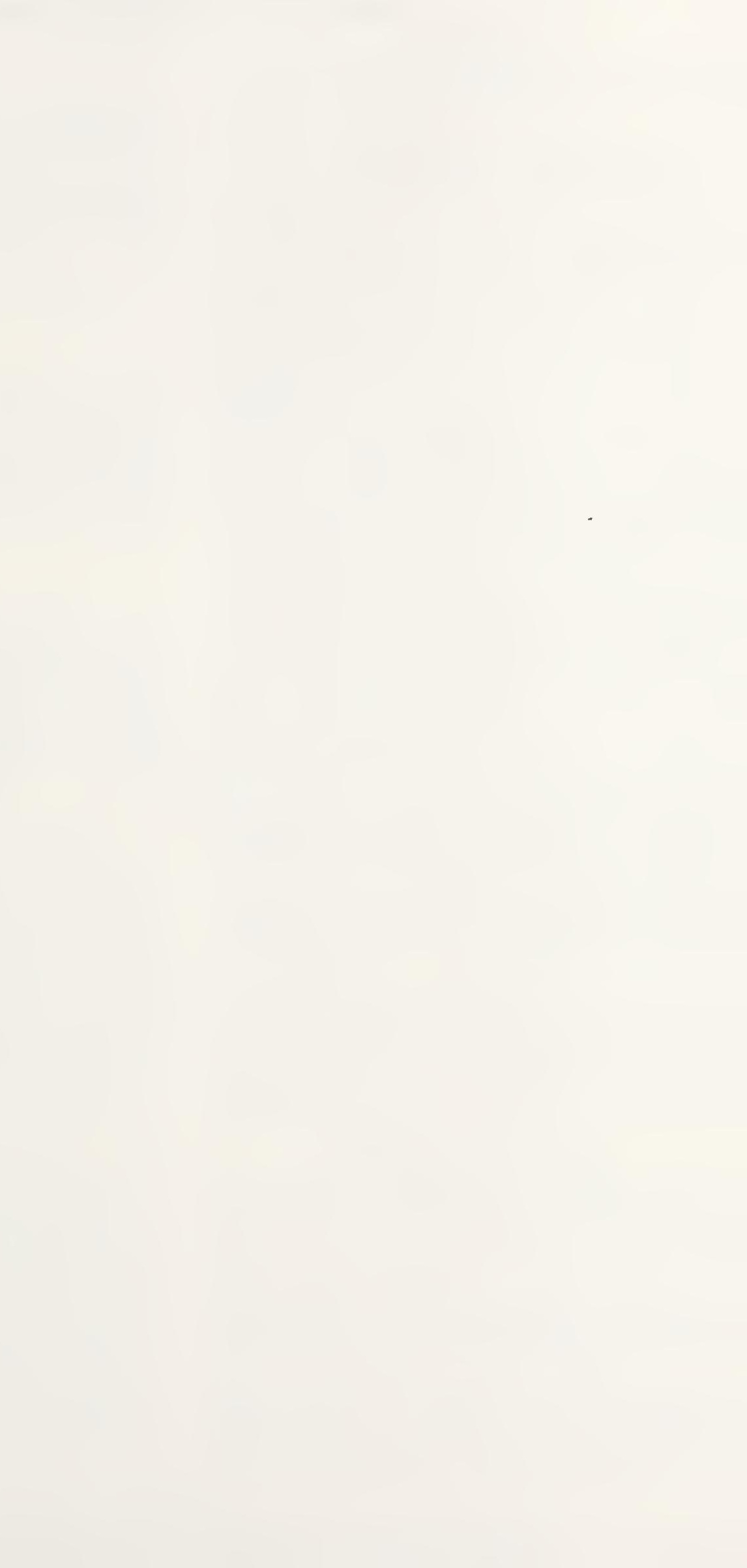



JOURNAL OF RESEARCH reports National Bureau of Standards research and development in physics, mathematics, and chemistry. Comprehensive scientific papers give complete details of the work, including laboratory data, experimental procedures, and theoretical and mathematical analyses. Illustrated with photographs, drawings, and charts. Includes listings of other NBS papers as issued.

Published in two sections, available separately:

\section{- Physics and Chemistry}

Papers of interest primarily to scientists working in these fields. This section covers a broad range of physical and chemical research, with major emphasis on standards of physical measurement, fundamental constants, and properties of matter. Issued six times a year. Annual subscription: Domestic, $\$ 9.50 ; \$ 2.25$ additional for foreign mailing.

\section{- Mathematical Sciences}

Studies and compilations designed mainly for the mathematician and theoretical physicist. Topics in mathematical statistics, theory of experiment design, numerical analysis, theoretical physics and chemistry, logical design and programming of computers and computer systems. Short numerical tables. Issued quarterly. Annual subscription: Domestic, \$5.00; $\$ 1.25$ additional for foreign mailing.

\section{TECHNICAL NEWS BULLETIN}

The best single source of information concerning the Bureau's measurement, research, developmental, cooperative, and publication activities, this monthly publication is designed for the industry-oriented individual whose daily work involves intimate contact with science and technology-for engineers, chemists, physicists, research managers, product-development managers, and company executives. Includes listing of all NBS papers as issued. Annual subscription: Domestic, $\$ 3.00 ; \$ 1.00$ additional for foreign mailing.

\section{Bibliographic Subscription Services}

The following current-awareness and literaturesurvey bibliographies are issued periodically by the Bureau: Cryogenic Data Center Current Awareness Service (weekly), Liquefied Natural Gas (quarterly), Superconducting Devices and Materials (quarterly), and Electromagnetic Metrology Current Awareness Service (monthly). Available only from NBS Boulder Laboratories. Ordering and cost information may be obtained from the Program Information Office, National Bureau of Standards, Boulder, Colorado 80302 .
Applied Mathematies Series. Mathematical tables, manuals, and studies.

Building Science Series. Research results, test methods, and performance criteria of building materials, components, systems, and structures.

Handbooks. Recommended codes of engineering and industrial practice (including safety codes) developed in cooperation with interested industries, professional organizations, and regulatory bodies.

Special Publications. Proceedings of NBS conferences, bibliographies, annual reports, wall charts, pamphlets, etc.

Monographs. Major contributions to the technical literature on various subjects related to the Bureau's scientific and technical activities.

National Standard Reference Data Series. NSRDS provides quantitative data on the physical and chemical properties of materials, compiled from the world's literature and critically evaluated.

Product Standards. Provide requirements for sizes, types, quality, and methods for testing various industrial products. These standards are developed cooperatively with interested Government and industry groups and provide the basis for common understanding of product characteristics for both buyers and sellers. Their use is voluntary.

Technical Notes. This series consists of communications and reports (covering both other-agency and NBS-sponsored work) of limited or transitory interest.

Federal Information Processing Standards Publications. This series is the official publication within the Federal Government for information on standards adopted and promulgated under the Public Law 89-306, and Bureau of the Budget Circular A-86 entitled, Standardization of Data Elements and Codes in Data Systems.

Consumer Information Series. Practical information, based on NBS research and experience, covering areas of interest to the consumer. Easily understandable language and illustrations provide useful background knowledge for shopping in today's technological marketplace.

\section{CATALOGS OF NBS PUBLICATIONS}

\section{NBS Special Publication 305, Publications of} the NBS. 1966-1967. When ordering, include Catalog No. C13.10:305. Price $\$ 2.00 ; 50$ cents additional for foreign mailing.

NBS Special Publication 305, Supplement 1, Publications of the NBS, 1968-1969. When ordering, include Catalog No. C13.10:305/Suppl. 1. Price $\$ 4.50 ; \$ 1.25$ additional for foreign mailing.

NBS Special Publication 305, Supplement 2, Publications of the NBS, 1970. When ordering, include Catalog No. C13.10:305/Suppl. 2. Price $\$ 3.25 ; 85$ cents additional for foreign mailing. 
U.5. DEPARTMENT OF COMMERCE

National Bureau of Standards

Washington, 0.C. 20234

OFFICIAL BUSINESS

Penalty for Private Use, $\$ 300$
POSTAGE ANO FEES PAIO U.S. OEPARTMENT OF COMMEACE 215

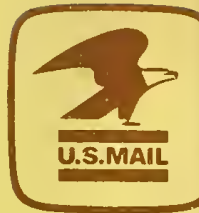

